Saints in Sight: Representations of Holiness in Late Medieval English Literature

\author{
Elizabeth Ann Sutherland \\ Chesapeake, Virginia
}

Bachelor of Arts, College of William and Mary, 2009

A Dissertation presented to the Graduate Faculty of the University of Virginia in Candidacy for the Degree of Doctor of Philosophy

Department of English

University of Virginia

May, 2016 
(C) 2016 COPYRIGHT BY BETH SUTHERLAND ALL RIGHTS RESERVED 


\title{
SAINTS IN SIGHT: REPRESENTATIONS OF HOLINESS IN LATE MEDIEVAL ENGLISH LITERATURE
}

Elizabeth Ann Sutherland

Drs. Bruce Holsinger and John Parker, Dissertation Co-Directors

\begin{abstract}
This project explores the aesthetic challenges of representing holiness, an intrinsically ineffable phenomenon. Specifically, I examine the late medieval English literature of sainthood. Textual representations of sainthood employ various tropes and topoi designed to render the saint opaque or indeterminate, preserving her inscrutable essence. These poetic attempts to unsay sainthood intersect with a contemporary discourse: apophatic (or negative) theology. Apophatic discourse leads readers into an experience of unknowing by negating, and so transcending, affirmative statements. This mode of theology saturated the vernacular theology of this period, but its effects on narrative literature—especially hagiography—remain understudied. I unearth and analyze the apophatic poetics of late Middle English representations of sainthood, looking at a thirteenth-century saint's life ("The Life of Saint Margaret" from the South English Legendary), a fourteenth-century travelogue (The Book of John Mandeville), and a fourteenthcentury dream vision (Pearl). Each text presents a deeply ambivalent portrait of sanctity, emphasizing the elusiveness of saintly figures. If sainthood resists definition, then, theoretically if not institutionally, it cannot be policed. The essentially mysterious nature of holiness creates a space of possibility. Who can delimit the category of saint? At its best, the medieval literature of sainthood participates in a major impulse of the vernacular: the desire for universal salvation.
\end{abstract}




\section{University of Virginia \\ Graduate School of Arts and Sciences \\ Department of English}

We hereby approve the dissertation of

Elizabeth Ann Sutherland

Candidate for the degree of Doctor of Philosophy

Bruce Holsinger, Ph.D.

Professor of English, Co-Director

John Parker, Ph.D.

Associate Professor of English, Co-Director

Kevin Hart, Ph.D.

Professor of Religious Studies

Gregory Hays, Ph.D.

Associate Professor of Classics

ACCEPTED

Ian Baucom, Ph.D.

Dean

Graduate School of Arts and Sciences 


\section{$+$}

Ad maiorem Dei gloriam

For my parents

In memoriam

Austin Colligan 


\section{TABLE OF CONTENTS}

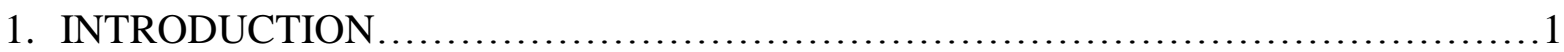

Holiness, Hiddenness, and the Task of Hagiography

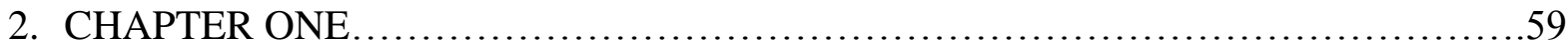

Sanctity and the Converted Gaze in the South English Legendary "Life of St Margaret"

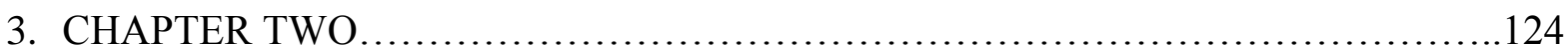

Saints and Salvation in The Book of John Mandeville

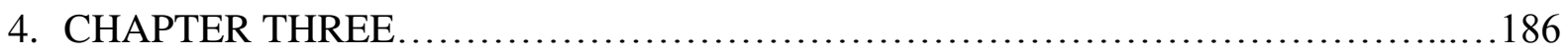

Alien Intercession: The Communion of Saints in Pearl

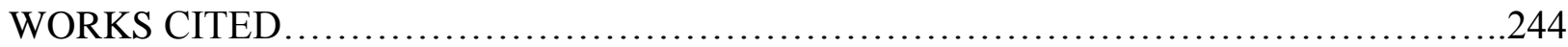




\section{INTRODUCTION}

\section{Holiness, Hiddenness, and the Task of Hagiography}

The saint. What sort of saint? No one has ever seen a saint. For the saint remains invisible, not by chance, but in principle and by right. - Jean-Luc Marion ${ }^{1}$

The saint is "the 'stranger' par excellence."2 Saints transcend material reality through their close affinity with the divine. They share in that which marks God's alterity: his holiness. If saints join God in being set apart, can they be recognized precisely as set apart? The dialectic between homeliness and the uncanny, presence and absence, hiddenness and revelation, intimacy and ineffability haunts all aspects of cultic devotion. This tension emerges in a special way with regard to the hagiographical tradition. According to one school of thought, holiness cannot be represented mimetically. Aesthetic depiction of an ineffable phenomenon would seem an impossibility. Yet this is the task of hagiography. The literature of sainthood must produce saintly visibility, rendering sainthood perceivable by imagining what holiness looks like. Saints are made, by God but also by culture. In both cases making has the full force of poesis. Legendum, the medieval word for saint's life, reveals the deep textuality of sainthood. Saints live lives that "ought to be read." Yet hagiography seeks to preserve the mystery of the holy even as it depicts holy persons. In order to represent holiness as such, hagiography must constantly undo its project of cataphatic (affirmative, imagistic) representation. It must mortify the gaze, hide the saint, offend the mind's eye - all in an attempt to let the dark luminescence of the holy shine forth more brightly. Because of this, the hagiographical mode of literature can be said to have an apophatic, or negative, poetics. It must render the icon without creating an idol. Hagiography has the difficult task of preserving the transcendent prerogative of holiness while creating an imaginary space within which one might contemplate holy persons. 


\section{Part I: Holiness and Hiddenness}

As both a historical phenomenon and a literary project, hagiography eludes concrete definition. The word is composed of the Greek roots hagios ("holy") and graphe ("writing" or “drawing”). It has been applied to many cultural traditions. ${ }^{3}$ The word was first used with reference to sacred scripture. Jerome (fourth-fifth c.) and Pseudo-Dionysius (sixth c.) refer to the Bible as hagiography. ${ }^{4}$ Late antique and medieval authors were more likely to use the designators "life" (vita), "acts" (acta), "passion" (passio), or "legend" (legendum). Nineteenthcentury scholars began the practice of referring to saints' lives as hagiography, cultivating the sense of genre that scholars have today.

For modern readers, the word hagiography refers chiefly to the lives (vitae) of the saints. This type of literature appeared in Christian culture almost immediately. The first century after Christ's death saw the production of several varieties: the canonical and apocryphal Acts of the Apostles, accounts of the martyrs' tribulations, and the prototypical gospels themselves. ${ }^{5}$ Though texts recognizable as saints' lives appear this early, the sense of a hagiographical project — of hagiography as a full-blown cultural phenomenon-probably emerged later. Eventually, hagiographers would develop such "self-conscious conventionality" that certain motifs and topoi appeared with predictable regularity. ${ }^{6}$ Derek Krueger suggests that "the first moment of explicit genre-consciousness occurred as late as the 440s, when a third- or fourth-generation hagiographer, Theodoret of Cyrrhus, argued that the 'lives... of the saints' should take its place among the classical genres."7 Saints' lives were already situated within a classical traditional of prosopography (Plutarch's Lives, for example). Within the umbrella category of hagiography, generic possibilities abound. Prose and verse vitae, inscriptions, lyric poetry, litanies, popular ballads, saint plays, sermons, trial transcripts, calendrical entries, canonization inquests, prayers, 
relic translation narratives, miracle books, and writings by individuals recognized as saints can all be considered writings about the holy. It therefore seems "best to consider hagiography not so much as a single genre, but as a collection of genres." ${ }^{\prime 8}$ Hagiography more resembles a literary mode than a specific and limited form. This dissertation examines one traditional work of hagiography, the "Life of St. Margaret" from the South English Legendary (thirteenth c.), but it also includes a travelogue (The Book of John Mandeville, fourteenth c.) and a dream vision in verse (Pearl, fourteenth c.). Though not classic saints' lives, both The Book and Pearl move in and out of the hagiographical mode. That is to say, they concern themselves with holy persons and seek to render that holiness legible.

Hagiography attempts to represent holiness textually. In order to understand hagiography, we must understand holiness (or sanctity). This is no easy feat. Within a Judeo-Christian theological framework, holiness is the quality most intrinsic to divinity. The Hebrew Bible and Greek New Testament repeatedly assert God's singularity by way of his holiness. "To whom can you liken me as an equal? says the Holy One" (Isa. 40.25). ${ }^{9}$ The Psalmist identifies the Hebrew God as exceptional because holy: "Your way, God, is holy; what god is as great as our God?" (Ps. 77.14) Hannah, mother of the prophet Samuel, offers this praise: "There is no Holy One like the Lord" (1 Sam. 2.2). In Isaiah and then in the Book of Apocalypse, the angels surrounding God's throne perpetually hymn the words, "Holy, holy, holy" (Isa. 6.3, Apoc. 4.8). "For you alone are the Holy One," claims the "Gloria in excelsis Deo," a late antique poem that was eventually incorporated into the Latin Mass. "Holy," then, is the adjective most proper to the divine essence. According to a medieval conception of God's being, God "possesses" all of his attributes uniquely. ${ }^{10}$ Aquinas addresses this in the Summa. He asks how goodness can belong to God, since it seems to exist as a mode or way of being. God is not ordered to any modality 
greater than himself. He is, according first to Augustine, modus sine modo, a way without a way. In the sed contra, Aquinas affirms that goodness not only belongs to God, it belongs to him most perfectly. Aquinas resolves this conundrum by relegating modality to the created, or caused, order. God is the cause, so he has no modality. Goodness originates in him; he is the Good. ${ }^{11}$ Goodness, like beauty and truth, was considered a transcendental, but one could make the same claim about any of God's "attributes." God is faithful, but not as man is faithful. Jealous, but with a difference. God may "be" certain adjectives in a super-exemplary manner, but "holy" is not just another adjective.

Holiness itself contains the idea of this excellence and singularity. Holiness does not make God unique; God is unique because he alone is holy. The Hebrew word qadosh, often translated as "holy," literally means "set apart."12 The Greek word hagios also contains this sense of consecrated difference or otherness, as does the Latin sanctus. The English word "holy" comes from the Old English halig, the word used to translate the Latin sanctus. Rather than denoting a positive, describable trait, holiness functions as a marker of difference. It indicates the distance between sacred and profane (profanus meaning "outside of the temple"). This means that "God's alterity imposes itself as absolute precisely as the alterity of holiness." 13 If holiness is the trait that fundamentally sets God apart from creation, then how can creatures know or perceive the holy? They can know it only by being swept up into it, and, since God alone is holy, only God can enable this participation. It is not a thing to be grasped.

Both the Jewish and Christian traditions imagine holiness as a quality that God shares with or imparts to his people through a process of sanctification. Though God is set apart in his holiness, others can join him in set apartness. One way to think of this paradox is that holiness originates in God alone and can be participated by God's people. To become increasingly holy is 
to enter ever more deeply into the divine life. In Leviticus, the book in which God creates his priestly class out of the Levite tribe, God affirms both the distancing and unifying aspects of holiness: "Do not profane my holy name, that in the midst of the Israelites I may be hallowed. I, the Lord, make you holy..." (22.32) This statement is borne out by the spatial dynamics of Hebrew ritual. The priests mediate between the inner sanctum — the Holy of Holies—and the Temple's outer chambers, to which others have access. God is set apart, yet in their midst. Not only that, but he shares a portion of his own holiness with those who set him apart. True, God addresses this promise of sanctification specifically to the priests, but elsewhere he extends it to the entire nation. He says to Moses, "Speak to the whole Israelite community and tell them: Be holy, for I, the Lord your God, am holy" (Lev. 19.2). This idea that God's holiness can be shared appears and is expanded in the New Testament. In fact, the author of 1 Peter quotes Leviticus in his exhortation to the churches, reminding them that "it is written, 'Be holy because I [am] holy"” (1.16). The Christian mission to the Gentiles sees itself as expanding an ancient promise. The possibility of sanctification implies that God's holiness can and does suffuse material reality. Somehow, this mysterious feature of the divine nature can have a presence in the created order. What does it look like, and how might one recognize it? Locating the moment when one understands one's awareness as an awareness of God remains difficult.

Theophany in the Hebrew Bible and Christian New Testament is always fraught. God's visual perceptibility in the (often iconoclastic) Old Testament is radically qualified. ${ }^{14}$ Adam and Eve enjoy God's immediate company in Eden but soon lose it (Gen. 3.8). After God banishes humankind from Eden, his apparitions are strictly mediated—by a burning bush or pillar of fire, for example (Exod. 3, 13.21). Attempting to bypass this mediation can result in death (2 Sam. 6.7). By selecting and dwelling among a specific people, God places himself close enough to 
touch. Yet his holiness keeps him infinitely distant. This irony appears most starkly in the conflicting accounts of Moses's conversations with God. God speaks with "Moses face to face, as a person speaks to a friend." Yet a few lines later, he reveals only his "back" to Moses, saying, "But you cannot see my face, for no one can see me and live" (Exod. 33.11, 20-23). Nor does the Incarnation "solve" this problem.

God's physical presence in the New Testament is also troubled. The doctrine of the Incarnation as articulated by the Council of Nicaea (AD 325) brings God firmly within the material realm: creator becomes creature, assuming flesh and living as a human person. Certain moments in the New Testament seem to encourage such a reading. "The Father and I are one," says Jesus in the Gospel of John (10.30). He expands this idea with the statement that "whoever sees me sees the one who sent me" (12.45). Other moments offer a slightly different account of the Christ. The author of Colossians calls Jesus the image, or icon, of the invisible God (1.15). An image of something is like that thing, but the very idea of representation suggests difference from that which is represented. Eighth-century iconodules would develop a sophisticated theology of icons in response to this problem, but this tension within Christianity's foundational scriptures reveals the paradoxes of divine manifestation. The particularization of divinity in a specific human person scandalizes Jesus's contemporaries. That a certain set of physical features might be identified with the traditionally invisible creator is, in its hyper-self-evidence, paradoxically hard to see. For Christians, human history climaxes with the redemptive life and death of Jesus. Yet this event remains elusive.

Jesus's contemporaries doubt him throughout the course of his ministry, so much so that it ends in condemnation and death. Oddly, the gospel authors write this doubt into their narratives, preserving it. They even imagine Jesus's most epiphanic moment - the 
Resurrection—as riddled with uncertainty. Mary Magdalene's discovery of an empty tomb affords the first "evidence" that he is risen. The miracle? His absence: "He is not here" (Matt. 28.6). When the disciples do encounter him, something always hinders their ability to recognize him — within the locked room, on the road to Emmaus, when fishing, and so on. Even Mary, who explicitly seeks Jesus and knew him intimately, mistakes him for the gardener (John 20.15). Why encode such ambiguity into the gospel narratives? Is this even Jesus at all, or some imposter? Though incarnate, God's holiness continues to set him apart, frustrating human economies of perception and interaction. He does not lay his Godhead bare to the gaze. ${ }^{15}$ Even when he reveals his divinity on the Mount of Transfiguration, he restricts access to Peter, James, and John, none of whom seems to understand what he sees. Indeed, these moments in the canonical gospels remind us of gnostic gospels such as the Gospel of Thomas, the Gospel of Mary, the Gospel of Philip, the Gospel of Truth, and the Egyptian Gospel, which emphasize and develop Christ's inscrutability. ${ }^{16}$ In the Gospel of Matthew, Jesus insists that the meaning behind his parables is (at least for the moment) only available to his inner circle. This secrecy complicates the distinction between an orthodox and a gnostic Jesus (13.11). Even Jesus's miracles—which seem like they should be straightforwardly epiphanic — occasionally obfuscate his divinity. To many, they smack of sorcery. ${ }^{17}$ This failure of Christ to achieve definitive recognition during his lifetime provides the comic stage upon which antichrists might ape divinity. These acts of mimesis only anticipate the final revelation, however. In other words, "the aesthetic of Christ and his doubles depends above all on the power of fallen material to represent the pure and immaterial, of history to signify the timeless, of human finitude to approximate the infinite..."18 Perhaps these moments of failed recognition contain a lesson. Jesus frustrates the easy connection between seeing and believing. He does this by keeping his identity on the cusp of 
perceptibility, but also by valorizing belief in the absence of sensory confirmation. He chastises Thomas, saying, "Have you come to believe because you have seen me? Blessed are those who have not seen and have believed" (John 20.29). Thank goodness, since, even when physically present, Christ remains difficult to see with the naked eye. His followers must train themselves to perceive a divinity that hides itself.

Within a Christian framework, a holy life participates in the vita Christi. The sanctified person becomes conformed to Christ, an alter Christus. ${ }^{19}$ Holiness, then, is an irreducibly supernatural phenomenon. Sanctification does not refer to moral perfection, though goodness bears a direct relationship to holiness. ${ }^{20}$ The "definition" of sanctity has no independent content of its own; rather, it describes a mode of relationality toward the divine. It consists more of a directionality than a set of specific acts. It reconfigures the thrust of one's existence. Only God's own activity can complete the process. Sanctification transfigures individual human persons. Greek Orthodox thinkers refer to this transformative process as theosis, or divinization, focusing on the soul's ability to share in the divine life. In the Judeo-Christian tradition, God's holiness is coordinate with his transcendence. When a person becomes sanctified, she enters into this alterity. Participating in the divine life entails a partial sharing in God's ineffable nature. If saints as such share in God's unknowability, then it would seem we have no hope of recognizing them as saints.

Contemporary phenomenology articulates this paradox most starkly. Holiness marks God's set apartness, often manifesting itself as absence. Following Michel Henry, Jean-Luc Marion applies phenomenology to the revelatory, transcendent realm. For Marion, anyone who thinks he has recognized a saint fools himself: saints are invisible. "The saint. What sort of saint? No one has ever seen a saint. For the saint remains invisible, not by chance, but in principle and 
by right." ${ }^{21}$ He borrows the language of praise for this declamation: le saint, le saint?, le saint. Holy, holy, holy. ${ }^{22}$ He affirms, questions, then negates the saint, arguing that she retains her invisibility in all circumstances. In order to recognize saintliness in another person, one must have experienced the phenomenon of holiness within oneself. On what other basis can one attribute it to another? Holiness cannot be defined, only known by direct experience. How does this work, though, if "no one can say 'I am a saint' without total self-deception"? ${ }^{23}$ To account oneself holy is to commit the sin of pride. In fact, the holier a person becomes, the more fallible she seems in her own eyes. The evidence of one's holiness must manifest during an encounter with the holiness of another. True recognition of the holy consists in understanding one's own lowliness. It is known not by similitude, but by disparity. Rudolf Otto calls this reaction the mysterium tremendum, a shuddering awareness of one's own creaturely nature. ${ }^{24}$ When Jesus's identity begins to dawn on Peter, the disciple does not gape or touch. He takes a step back: “Depart from me, Lord, for I am a sinful man." (Luke 5.8). So strong is his reaction, he dares to address Jesus with an imperative. This reaction sanctifies Peter. According to Marion, presuming to comprehend and label the holy verges on idolatry, and "all idolatry actually results in selfidolatry." 25 One's own standards become the measure of the divine. The holy's elusiveness consigns saintliness to formal invisibility.

Marion then draws an analogy to another phenomenon that does not admit of direct experience: death. He makes the simple point that no one can bear witness to death in the firstperson. Those who, like the survivor in the Book of Job, alone return to tell the tale do not have the full story. ${ }^{26}$ Marion could take up the question of the martyr here, and her own unique witness, but he lets that pass. Instead, he identifies Christ as the site where holiness and death most perfectly intersect. God literally shows himself to the world in the person of Christ; he 
preserves the holy's "fundamental characteristic — its invisibility from the world's point of view... This contradiction culminates in Christ's silence and disfigurement at the time of his Passion, where the maximum of holiness is swallowed up by the maximum of invisibility, of death." ${ }^{27}$ At the peak of his salvific mission, Christ proves most abject—least recognizable as God. Marion concludes swiftly and weirdly, alluding to Pascal's "three orders": flesh, mind, and heart. No order can see or understand the order(s) superior to it. So it is with sainthood. One must be a saint in order to recognize sanctity in another. This means that the eyes best-suited to recognizing the saints are God's. The shepherd knows his flock. ${ }^{28}$

Marion makes a powerful case for why sanctity’s phenomenality must remain invisible, but his disturbing claim invites further conversation. For example, how does one attain to this third order of knowing? How does the mysterium tremendum effect or enable sanctification? Most striking of all, how do we account for all the accoutrements of cultic devotion, which somehow mediate sanctity to devotees? Consigning holiness to absolute invisibility seems to preclude the possibility of recognizing and so being drawn to it-which in turn makes sanctification impossible. There must be a kind of "recognition without recognition" if conversion is to remain possible. Petra Turner develops the concept of saintly invisibility within the context of Marion's larger body of thought. Employing his doctrine of the saturated phenomenon, a phenomenon whose intuition (in-flowing) exceeds one's ability to intend (reach out to) it, Turner sheds some light on Marion's argument. She gives saintly invisibility a richer texture, distinguishing it from something like an abyss or vacuum. The perceiver experiences saintliness "as something outside of and foreign to oneself, and perceives and receives it as a conceptual lack, as a space where the profane cannot enter" (emphasis added). ${ }^{29}$ What is experienced as lack, however, is actually the sense of a fullness that exceeds one's ability to 
perceive and conceive of it. We might liken an experience of holy hiddenness to the paradoxical realization that one has a blind spot. How does one come to see a blind spot? This experience has a negative component: holiness "inscribes itself in the individual's response to it," carving out a space within the individual. ${ }^{30}$ To see holiness is to repent; to repent is to begin to become holy. This participation increases one's ability to receive the phenomenality of holiness even more. Turner calls this the "holy dance of encounter and change." ${ }^{31}$ Though clarified by the use of a larger philosophical vocabulary, the idea of saintly invisibility remains an insoluble problem. That moment of conversion retains its profound mystery. What makes one person jeer at the Crucifixion tableau and another weep? As Turner points out, "to recognize the holy is already to be caught up in it." ${ }^{\prime 32}$ A basic tautology resides at the heart of the thesis proposed by Marion and elaborated by Turner: one must belong to holiness in order to recognize it, and one must recognize holiness in order to belong to it. This quasi-gnostic conception of sainthood is insufficient.

Christians have always imagined saints as intercessory beings. In some way—however qualified — saints ostensibly strive for recognition, precisely because they desire to be companioned. The production of saints depends upon the recognition of saintliness. People who come to be recognized as saints have often positioned themselves within a genealogy, or are imagined as having done so. Dorothy Day (twentieth c., whom the Catholic Church is considering for canonization) quotes Thérèse of Lisieux (nineteenth c.), who authored plays about Joan of Arc (fifteenth c.), who in turn invoked Margaret of Antioch (third c.), who, legend has it, craved martyrdom upon hearing the stories of Sts. Lawrence (third c.) and Stephen (first c.). Saints are creatures of community. If the greatest commandment, according to Christ, is to love God, the second most important is to love one's neighbor (Matt. 22.36-40). The neighborly 
imperative of holiness makes its set apartness not exclusive, but invitational. In one of the most popular texts of the late Middle Ages, a collection of vitae known as the Legenda aurea, or Golden Legend, Jacobus de Voragine (thirteenth c.) offers this account of All Saints Day: "The saints make festival in heaven over us, for there is joy before the angels of God and holy souls over one sinner doing penance, and so we should make a fair return by celebrating their feasts on earth. ... When we pay tribute to our brothers, we honor ourselves, since love makes all things to be in common, and all things are ours, in heaven, on earth, and in eternity." 33 The feast days that pepper the medieval calendar reflect the celestial celebrations that these intercessory figures make in heaven, rejoicing when a soul is added to their number. Though the saint refers her being to God, doing so refers her back to humankind. Saints are ineluctably pro nobis. Their project of imitatio Christi drives them to serve and commune with others, whether through heavenly prayer or earthly ministry. The communion of saints unites the church triumphant with the church militant, extending the church's sociality from this world into the next. The saints are nothing less than a great "cloud of witnesses" (Heb. 12.1). Surrounding the heavenly throne, they are caught up in the beatific vision, gazing at the Godhead and offering ceaseless hosannas. But they are also imagined as looking downward, their eyes glued to the spectacle of human suffering. They cheer the living on as if they watched a sporting event. Occupying the space inbetween God and the world, the saint is a Janus-faced creature, simultaneously focused on heaven and earth. The cloud of witnesses both witness and bear witness to God, reflecting his glory in their own luminous souls. Hagiography must figure out a way of holding their invisibility in tension with their visibility. For if one cannot see holiness, it is by no means true that one looks on holiness and sees nothing. 


\section{Part II: The Aesthetics of Sanctity}

If holiness as such remains invisible, what does one see when one looks on a saint? What does a saint look like? This is an aesthetic question. It explores the connection between human sense perception and divine activity. Since Christianity's earliest days, thinkers who have wanted to understand sanctification have favored one mode of writing above others: hagiography. As noted, the "writing" of "holy writing" also means "drawing." Iconographers, though they produce visual images, are said to write icons. So does a hagiographer present "a verbal portrait or icon of the saint." ${ }^{34}$ It has become commonplace to point out that the Western church has an underdeveloped numinology, or theology of the Holy Spirit. Yet it has an overabundant tradition of spiritual writing. "Spirituality is at the core of any practice of a religion." 35 It encompasses lived, embodied faith. As a kind of spiritual writing, hagiography addresses the question of God's activity in the sensible world.

In its attempt to understand and then depict the mystery of sainthood, the hagiographical mode can itself be understood as a phenomenology of sanctity. The hagiographer examines the phenomenality of holiness as embodied by exceptional individuals. He then recreates artistically what he perceives — whether with his bodily eye or his mind's eye — producing a virtual experience of sanctity. Let us not confuse this process with reporting. The hagiographer stylizes sainthood, refracting its ineffable quality through the prism of artistic interpretation. Each literary device he employs acts as a facet on this prism, drawing out the hidden, invisible colors of sanctity's light. In so doing, he performs what I call the hagiographical reduction, leading the mystery of embodied sanctity back to the perceiver through the mediation of a literary product. As aesthetic endeavors, saints' lives do not seek explicitly to define holiness. Rather, they represent it in dynamic, painterly terms. Husserl himself, the father of modern phenomenology, 
"wrote of the closeness of the phenomenological and the aesthetic gazes." 36 Artistic endeavor affords one way of performing the phenomenological reduction. It employs and fosters the sort of beholding to which phenomenology exhorts us, even if it eschews the technical vocabulary. ${ }^{37}$ Self-consciously to translate reality so that it might be understood and beheld while simultaneously adding to the mystery and depth of that reality: this is the project of art. That such translation is especially needed in the case of saintly persons is attested by the wealth of artistic renderings that survive and continue to be produced in the form of narrative prose, homiletic prose, verse, stained glass, jewelry, reliquaries, statuary, drama, icons, carvings, ballads, film, and more.

The visibility of the saints emerges within a literary tradition that not only represents them, but also makes the idea of sainthood thinkable. Perhaps, in some abstract way, sainthood as such is formally invisible, as Marion argues. Practically speaking, however, sainthood never exists in isolation: it always springs forth from a representational tradition from which it cannot be divorced. This tradition allows its phenomenality to emerge. Saints are textual creatures. Both literary-historical and theological data support this claim. Christian sainthood is premised upon the imitation of Christ, who is himself Word made flesh (John 1.14). The Incarnation, which gives humanity a visible instantiation of the divine, resembles an act of cosmic writing, translating the divine Word into material reality. Christ's afterlife in the gospels and other literal, legible texts further compounds this translation. Theologies of the divine Logos aside, Jesus of Nazareth was firmly rooted within a Jewish scriptural tradition. Much of his speech as reported in the gospels quotes and interprets the "Old" Testament. "Jesus' own conscious imitation of scriptural types" invited the gospel writers to imagine other parallels, producing a typological relationship between the Old Testament and the earliest Christian writings. ${ }^{38}$ Saints carry this 
typological relationship forward, imagining themselves as the Body of Christ. Additionally, the material realities of ancient and medieval writing lent themselves to a theology of text and flesh. ${ }^{39}$ The process of writing "bridged the mental and the bodily; while the written text, inscribed on papyrus or on skin, was embodied logos.. ${ }^{40}$ A saintly life, as lived in material reality, bore a direct relationship to the literary vita representing it. Even if the vita was mostly imaginative embellishment, it gave her a liveliness that continued past death. The saints that were pure fabrications of a hagiographical tradition almost literally took on a life of their own. A textual life conferred a kind of presence, even in the absence of a corresponding biological life. As Robert Bartlett puts it, "The saint is only seen through the writing about the saint as saint." This both manifests and hides the individual venerated. Usually, "there can be no lifting of the veil; it is a veil that is created by the fact that, by the time people in the present can have any kind of encounter with the long dead person, that dead person has already been conceptualized as a saint, with all the implications. ${ }^{\circ 2}$ The abstract concept or theoretical phenomenon of sainthood might well remain invisible. The logic behind Marion's claim is compelling, even relentless. Yet it may be irrelevant. For sainthood is always an incarnational, particularizable phenomenon; it never exists in the abstract. A historical and theological precondition to its existence is the textual tradition preexisting and enabling it in the exemplarity of Christ, both as a man about whom stories were written and as the incarnate Word from whom sanctity proceeds. Sainthood's existence is contingent upon the artistic tradition that produces and enables its visibility, however mediated. Saint-making is always poesis. God and humankind collaborate through a process of cultic creation. In an attempt to accommodate a commonsense understanding of sainthood, I argue that it can be recognized as sainthood, if only through the mediation of a cultic tradition that renders its form somehow manifest. This does not mean, however, that sainthood is subject 
to easy and unqualified revelation. The same literary tradition that guarantees the saints' presence also acknowledges and preserves their inscrutability. This dialectic is the mechanism by which saintly representation becomes possible.

The saint's absence is the wound at the heart of cultic devotion, originally the result of literal wounds. The hero of any hagiographical text manifests an absent body. She does so precisely because hers is a textual body, however visual its poetic construal. ${ }^{43}$ Yet even though "texts might substitute for bodies, texts did not provide an opposition to the body."44 The saint is endowed with a "textual body," able to absorb the demands of both visibility and invisibility. ${ }^{45}$ She is read, her body delivered to the mind by way of language. This non-apparitional quality of textuality becomes ironically "apparent" in the overdetermined visuality of martyr texts, the earliest of which presented themselves as word-pictures, exhorting the hearer or reader to envision the absent saint. This imagistic impulse contains the seeds of its own deconstruction, ultimately reminding the reader of the saint's physical absence. Even when a relic endowed the saint with physical presence, much imaginative and theological work assisted its manifestation as more than inert matter. Focusing on sculptural art objects, Peter Brown argues that "the art of the shrine in late antiquity is an art of closed surfaces. Behind these surfaces, the holy lay, either totally hidden or glimpsed through narrow apertures. The opacity of the surfaces heightened an awareness of the ultimate unattainability in this life of the person they [i.e., pilgrims] had traveled over such wide spaces to touch." ${ }^{46}$ This may sound pessimistic, yet the "carefully maintained tension between distance and proximity ensured one thing: praesentia... the presence of an invisible person." ${ }^{47}$ If this paradoxical absence-presence seems irreducibly mysterious, one thing is certain: artistic mediation makes it possible. While the hagiographical mode certainly evolved throughout the Middle Ages, an intensely visual poetic remained at its core, a generic 
holdover from its late antique past. Often the language with which scholars discuss passion narratives slips into the immediate and spectacular, seduced by the texts' ocular rhetoric, treating the subject as if she were immediately present. ${ }^{48}$

Accounts of the martyrs deal with this presence-absence, visibility-invisibility most overtly, being self-proclaimed accounts of witness. Early Christians obsessed over the fate of martyred bodies. ${ }^{49}$ These bodies comprised the raw material of Christian cult-making and so had a formative impact on hagiography. The word "martyr" means "witness," a juridical term that accrued its sacrificial and supernatural valence with the persecutions of Christians that occurred sporadically in the late antique world. These persecutions were by no means as systematic, constant, or unbridled as Christian accounts — especially passion narratives - make them seem. ${ }^{50}$ In fact, violence in late medieval hagiography more directly evoked Inquisitional and political torture enacted by Christians than actual conflict with pagan oppressors. ${ }^{51}$ Yet the cultural trauma of martyrdom created a deep wound. ${ }^{52}$ The threat of martyrdom shaped the collective Christian consciousness - manifest in its art, liturgy, theology, burial practice, and so on - to say nothing of the actual experience and testimony of those who witnessed or underwent such executions. ${ }^{53}$ The possibility of torture and capital punishment inspired Christians to respond dialectically to state violence, producing a literature of triumphant suffering. The term "martyrdom" is value-laden, reflecting a desire to find meaning in pain, to remember the dead, and to produce a "useable story" that could be handed down. ${ }^{54}$ If an individual can undergo sanctification, and if that person can be represented and venerated by means of art, then what separates Christian saints from pagan gods? What keeps devotees from idolatry? Most of the early martyrs were sentenced for refusing to burn incense for the gods. Yet within generations, devotees would burn incense for those same martyrs. 
Many attributes that medieval writers ascribed to idols consistently appear in hagiography. They exist alongside a series of iconoclastic moves meant to discredit these compulsively reproduced idols. Michael Camille notes that three types of images "are most often erased from manuscript representations because they offended their later audiences: genitals, devils, and idols." ${ }^{55}$ Especially in martyr narratives, idols loom large as the enemy behind the enemy - the site of discord, where the Christian proclaims his identity by refusing to acknowledge pagan gods. Idolatry colored the entire spectacle of martyrdom, both the moment of defiance and the punishment itself. The Roman arena was a religious space, which "resonated with the rites and rituals of pagan worship and the spiritual as well as the emotional atmosphere was utterly unwholesome" to Christians. ${ }^{56}$ The early hagiographer Prudentius (fourth-fifth c.) decried the "implicit sacrifices to the king of the dead... for the chthonic deities took real shape as demons in the Christian psyche." ${ }^{57}$ Even in their rejection of the pagan gods, Christian martyrs were made to enact involuntary ritual sacrifices to those gods. This was a lot of symbolic infrastructure to negate or invert, so it is unsurprising that anxieties about idolatry would complicate veneration of those same martyrs. The practice of relic veneration, which grew out of the cultic devotion to the fragmented bodies of the martyrs, incurred "both outright and implied charges of idolatry" in the fourth and fifth centuries. ${ }^{58}$ Such charges recurred sporadically throughout the Middle Ages with perceived abuses, returning definitively during the Reformation. Earlier, many theologians denounced icons as false images. Augustine (fourth-fifth c.) "lamented that the church had embraced such visual art in the first place and noted that pagans in Hippo had charged Christians with the very kind of idolatrous adoration of images of which Christians had accused them."59 If Christians wanted to manifest the hidden holy through artistic rendering, they would need to negotiate the tight relationship between idol and icon. 
Christians toppled what they saw as pagan idols, but they did not leave the pedestals empty. Illuminated images of the Virgin and Child perched upon altars replaced those from which the pagan idols had fallen. Discomfited, Abelard asks of such images, "can Our lady wish to be represented in a sculpted image as Vesta did?" The hagiographical tradition answered in the affirmative, as tales of saintly statues springing to life multiplied. ${ }^{60}$ Far from escaping pagan idolatry, medieval artists engage in a process of iconotropy, appropriating the symbolic power of images and narratives that predate Christianity. ${ }^{61}$ Though he does not claim that Marian devotion constitutes the same phenomenon as sacrificing to Venus, Camille troubles the notion that medieval illuminators and authors achieve a clean break between the two. As Christian saints began to look more like the idols they had toppled, "idol" became a category of religious and ethnic difference. Heretics, Jews, and Muslims were imagined as committing various forms of idolatry, and thirteenth-century readers of martyrdom tales drew on this contemporary idolatrous imaginary as well as fantasies about the pre-Christian past. This displacement of idolatry onto religious, political, and ethnic Others did not, however, exorcise hagiography of its preoccupation with sanctity's inscrutability.

\section{Part III: Hagiography's Apophatic Poetics}

The hagiographical mode contains a paradox at its heart. Saintly bodies assume a measure of God's ineffability, which would seem to frustrate the project of aesthetic representation. Saints must “manifest exteriorly the 'hidden' life... [of Christ], but in order to do this, they must have begun by 'hiding' Him in their hearts." ${ }^{2}$ We have already seen how Christ's own presence, even his Resurrection apparitions, is fraught with a sort of invisibility. Christ contains "not only the visibility of the Godhead, but also the invisibility: if Christ is the Way, Christ is, in short, our access to the unknowability of God, not so as ultimately to know it, but so 
as to be brought into participation with the Deus absconditus precisely as unknown." 63 Hagiography works to reconcile this joint imperative of hiddenness and manifestation. The hagiographical reduction leads readers back to sainthood by guiding them through a thick cloud of unknowing. Saints' lives contain numerous moments of negativity, opacity, blindness, indeterminacy, darkness, and unknowing. The hagiographical mode has developed many motifs and topoi in order to express sanctity's elusiveness. It has an apophatic poetics.

A parallel strain of discourse developed alongside hagiography, asking the same questions about representation and holiness. Apophatic theology, known also as negative theology or the via negativa, responds to concerns about God's hiddenness. It emerged out of early contemplative thought. It now constitutes an entire theological tradition, albeit one that remains inextricably braided with the cataphatic tradition. In some ways, apophatic conceptions of the divine allowed proponents of Christian art to both have and eat their cake. ${ }^{64}$ From the beginning, apophatic theology was embedded in theological discussions about images. Nor was it a fleeting movement, only occasionally in the air for subsequent generations of Christians. The liberating logic of the via negativa enabled and encouraged a rich material tradition — and it never went away.

The Mystical Theology of Pseudo-Dionysius the Areopagite gives voice to the most influential expression of apophatic theology. ${ }^{65}$ The text was probably written by a late fifthcentury Neo-Platonist from Syria, though the author purports to be the Dionysius converted by Paul in the Acts of the Apostles. Within the realm of theology (i.e., "speech about God"), apophasis involves negating statements about the divine. Emphasizing divine transcendence, apophatic discourse posits God as essentially ineffable, reasoning that language approaches him best through negative speech. Negating statements about God reveals the dissimilitude between 
Creator and creation, defamiliarizing language in order to free it from idolatry. More broadly, negative theology builds on this notion of unknowability, instructing others how to apply its truths to the practice of contemplation. The Mystical Theology contains statements like "I pray we could come to this darkness so far above light!" and "the more we take flight upward, the more our words are confined to the ideas we are capable of forming." 66 Though themselves poetic and metaphorical, these statements imply that words, images, and even ideation necessarily restrict our understanding of God. Only once these things have been transcended is “experience" of God possible. Despite this, the author's extremely metaphorical language itself evokes all manner of images.

One illustration proves especially bemusing, highlighting the lingering tension between idol and icon. The post-Constantinian world of late antiquity held pagan art objects in contempt, decrying pagan statues as idols — false, because constructed by human hands out of inert matter, and dangerous because demons might inhabit and animate them. In response to the pagan past, Christians regarded three-dimensional, rounded art with suspicion until well into the High Middle Ages. ${ }^{67}$ It seems strange, then, that Pseudo-Dionysius would use sculpture as a means of describing the contemplative path to God: "We would be like sculptors who set out to carve a statue. They remove every obstacle to the pure view of the hidden image..."68 If words, images, and ideas get in the way of God, then these things prove analogous to the chunks of stone that the sculptor clears away. Following the logic of the treatise, one would think that empty space (perhaps a concave imprint?) would signify divinity, but not in this particular conceit. Anticipating Michelangelo’s famous statement by about a millennium, Pseudo-Dionysius imagines a form latent within raw material, waiting to be released. The theologian effectively invites his readers to carve a mental statue and proclaim it God. This metaphor, embedded in the 
heart of negative theology's most classic text, reveals paradoxes inherent in speech about the transcendent. It indicates the indispensable role of images in speaking and envisioning the holy. It also flags the tension between icon and idol. Ironically, Pseudo-Dionysius borrows this idea of latent form from pagan culture, where myths of statues coming to life abound. ${ }^{69} \mathrm{He}$ emphasizes process over end-result, and the potentially infelicitous statue seems less important for him than the discipline of chipping away.

Proponents of Christian imagery roundly rejected charges of idolatry (whether rightly or no), as Pseudo-Dionysius would undoubtedly have done. He would not have been concerned by the presence of image, metaphor, and affirmation within his text. For the Mystical Theology is one of four treatises associated with the author and is the shortest by far. The others deal with Christianity’s most cataphatic (affirmative, conceivable, imagistic) aspects, such as the ecclesial hierarchy, the variety of angelic beings, and the names of God revealed in sacred scripture. Apophatic theology was firmly rooted within a sacramental, ecclesial, and poetic context. Its practitioners referred to the Incarnation as proof of God's immanence in the world and the dignity of material reality. These two conceptions of God—often described as flipsides of one coin-were kept in productive tension only with great difficulty. The via negativa favored the language of prayer and worship, culminating in a contemplative silence meant to lead toward ecstatic union with God. In the West, it complemented the technical, philosophical language of scholasticism. ${ }^{70}$ It was sometimes accused of being too mentalist and individual a practice. Critics feared that practitioners might bypass the church, preferring individual experience to doctrine and the sacraments.

Pseudo-Dionysian thought saturated medieval Western theology. Greek Orthodoxy had informed and infused Celtic religious practice. The transmission of Eastern texts to the far West 
helped shaped Irish monasticism. ${ }^{71}$ The British Isles inherited its hagiographical tradition from the Greek East (in the martyr narratives and Athanasius's Life of St. Anthony, fourth c.) as well as an anxiety about holy images and a penchant for negative theology. Around the time of the Second Iconoclasm in Byzantium (mid ninth c.), an Irish Neo-Platonist named Johannes Scotus Eriugena translated the works of Pseudo-Dionysius into Latin. His was the second Latin translation. The Abbey of Saint Denis produced the first a few decades prior, having obtained a Greek manuscript from a Byzantine ambassador to the court of Louis the Pious. Eriugena's translation ultimately enjoyed more influence. Aquinas cites Pseudo-Dionysius around 1,760 times in his Summa. ${ }^{72}$ English thinkers take apophaticism up with gleeful enthusiasm. One fourteenth-century chronicler claims that the Mystical Theology "ran through England like the wild deer."73 The anonymous fourteenth-century Cloud of Unknowing, a treatise on prayer, provides a classic example, and, indeed, its author also produced a vernacular translation of the Mystical Theology. Stirred by love, the contemplative must place "a derknes or a cloude" before her eyes. This darkness surpasses that of nighttime in its profundity. "For when I sey derknes, I mene a lackyng of knowyng; as alle that thing that thou knowest not, or ells that thou hast forgetyn, it is derk to thee." This "cloude of unknowyng" can be seen with neither bodily nor "goostly" eyes. ${ }^{74}$ Thus, the way to God becomes a kind of non-experience, a pilgrimage into darkness later epitomized by John of the Cross's (sixteenth c.) “dark night of the soul.” Any examination of Western religious writing must take the apophatic tradition into consideration. This contemplative, quasi-deconstructive, ultimately poetic discourse provides the qualifying backdrop for any cataphatic statement or material-visual image - and vice versa. Hagiography is no exception. 
Hagiography employs various and bizarre literary strategies in an attempt to address the problem of the holy's inscrutability. Patricia Cox Miller treats hagiography "not as a discrete genre limited to literary lives of saints but rather as a set of discursive strategies for presenting sainthood." ${ }^{, 75}$ This discursive technique (what I have called the hagiographical mode) side-steps idolatry by endowing the saint with an "apophatic body" or a "subtracted self.,"76 Uncanny representative techniques mediate the saint's body. This dislocates saintly presence, producing a “'haunting' whereby the saint's textually reconstituted body flits in and out of focus, tantalizing the reader with intimations of complete divine-human synergy." 77 Such material indeterminacy saves the saints from reification. These "subtle embodiments are the hagiographical version of apophasis."78 Presumably this apophatic hagiography shields the devotee from idolatry by informing the way he perceives or conceives of the imagery, both frustrating and opening up the mind's eye. This "spiritual exercise" helps prime the physical eyes to interpret material representations of the holy with a deeper understanding of matter's ambivalence. ${ }^{79}$

A template for hagiography's apophatic poetics emerges organically from the treatises of Pseudo-Dionysius. When we take the totality of his writings into consideration, three stages of aesthetic imagination emerge: affirmation (positive cataphasis), defamiliarization (negative cataphasis), and pure negation. This is his process. The contemplative must pass from one stage to the next, culminating in the darkness of unknowing. Pseudo-Dionysius concerns himself as much with aesthetics as with ontology.

The first step involves cogitating on positive, cataphatic affirmations about the divine. Before attaining Sinai's misty heights, the Christian must meditate upon a vast array of signs, both images and names, especially those symbols revealed in sacred scripture. Before negating them, Pseudo-Dionysius celebrates and reveres visual and mental imagery, as well as linguistic 
affirmation. For Pseudo-Dionysius, type bears a real, if mysterious, connection to archetype, so poetic expression can raise the mind upward. ${ }^{80}$ This is why the Iconodules cited him as a champion of religious art. Though the divine essence resides beyond our capacity for thought (and therefore language), "generously and as far as may be, it gives out a share of what is hidden." ${ }^{\prime 11}$ It does this through scriptural utterance and through creation itself. All entities receive their being from God and so manifest a part of him. This is why God can be described as a "light," "rock," or "lamb." Significantly for Western thought, Eriugena also takes up this "theory that creation has a sacramental value as a sign of the divine essence." 82 All entities convey something true about God inasmuch as they have their being from him. Human sense perception necessitates "that we use letters, syllables, phrases, written terms and words," but the intellect has the potential to go farther. ${ }^{83}$ Pseudo-Dionysius offers a method for doing so.

The second stage takes the contemplative beyond easy similitude. The way to mystical darkness leads through the denial of all affirmative statements about the divine. This process of denial does not undo the truth-value of statements such as "God is good," because the apophatic ontology places God beyond being. A statement about the nature of his being might be true, but truer still is the mystery that resides beyond the articulable. Before broaching that ultimate mystery, the contemplative must linger on the second step: defamiliarization. A true and positive affirmation undergoes a sort of distortion, or pre-negation, before vanishing due to its inadequacy. We might consider this negative cataphasis. It deals in imagery and demonstrability, even if the resultant aesthetic startles rather than comforts. Before receding into the darkness of unknowing, statements about the divine must grow strange. A homely image becomes uncanny, deformed, or even horrifying, preserving God's alterity. "God is good” becomes "God is not good," which invites one to imagine that "God is evil." The whirlwind God of Job—who glories 
in his most monstrous creations, seemingly indifferent to humanity's suffering-counters the image of God as "father" or "shepherd." Pseudo-Dionysius insists that incongruous symbols often disclose God's nature more effectively because they rouse the devotee from her cognitive complacency.

Pseudo-Dionysius's treatise the Celestial Hierarchy addresses defamiliarization most directly. Do angelic beings literally have the bestial and grotesque forms with which scripture endows them? Sacred poetry deploys "images in which like represents like," but it also relies on "formations that are dissimilar and even entirely inadequate and ridiculous." ${ }^{84}$ Even in his defense of these images, he protests a bit much, reminding us that the iconoclastic fear of images never disappears entirely: "We cannot, as mad people do, profanely visualize these heavenly and godlike intelligences as actually having numerous feet and faces," yet the "Word of God makes use of poetic imagery... as a concession to the nature of our own mind." ${ }^{" 85}$ Monstrous images exhort the reader to ascend toward the imageless, because "the sheer crassness of the signs is a goad" to leave shameful depictions behind. ${ }^{86}$ This ascent is by no means assured; monstrosity has its own fascination, and one might become transfixed by its lurid appeal. Pseudo-Dionysius betrays an anxiety that monstrous images might arrest the mental gaze. In fact, his own narrative betrays these symptoms of fascination. He delectates in, compounds, and reproduces these problematic word pictures in his own prose:

They [angels] are not shaped to resemble the brutishness of oxen or to display the wildness of lions. They do not have the curved beak of the eagle or the wings and feathers of birds. We must not have pictures of flaming wheels whirling in the skies, of material thrones made ready to provide a reception for the Deity, of multicolored horses, or of spear-carrying lieutenants... ${ }^{87}$

The theologian's theory allows him to indulge in such elaboration while retaining plausible deniability: the more lively the grotesques, the more wildly they gesticulate to something beyond 
imagining. "Unlike symbolism" makes "the images themselves almost literally ambivalent" and are necessary in order to "form some conception of the invisible realm." 88 Yet what if the contemplative gets stuck? According to Pseudo-Dionysius, scriptural signification is not thereby frustrated: the profane remain outside the temple, where they belong. ${ }^{89}$

Monstrous imagery yields a unique understanding of the holy as set apart. Yet these poetic images of the divine must be held in tension with its intrinsic goodness. As Otto insists, this fear may resemble natural terror, but it proves qualitatively different. 'The 'shudder' reappears in a form ennobled beyond measure where the soul, held speechless, trembles inwardly to the farthest fibre of its being." 90 These monstrous pre-negations are not "simply the opposites of the affirmations," they are indications of divine transcendence. ${ }^{91}$ Meditating on God's "monstrous" attributes produces a deeper understanding of the mystery that is God's nature. This makes etymological sense: monstrum comes from monstrare (to show) and relates to words like “demonstrate." It also bears a relation to monere (to warn), from which we get "admonition." This uncanniness displaces the contemplative from her cozy relationship to linguistic and aesthetic signification, preparing her to negate the symbol more completely.

The third and most challenging stage entails a more absolute process of negation. Instead of "God is not-good" or even "God is evil," the contemplative strives for "God is geød." More ideally: __ Words, concepts, and images should fall away. ${ }^{92}$ The contemplative arrives at a semantic void, one characterized by an overabundance of meaning as opposed to nothingness. This final move constitutes the heart of classical Pseudo-Dionysian apophatic theology. Ironically, it inspires great heights of lyricism. The Mystical Theology begins with a hymn in which the theologian hopes to reach the place "where the mysteries of God's Word lie simple, absolute and unchangeable in the brilliant darkness of a hidden silence." 93 The divine 
essence recedes, but, like a lover, it expects to be chased. The darkness swathing it has a paradoxical glow. Though the "experience" of this contemplative height resists translation into words, spiritual writers have tried over and over to convey some sense of its reality. Apophatic thought leaves the devotee with cataphatic images, with estranged versions of those images, and then without images. Hagiography draws on each of these phases in its attempt to represent the holy, sometimes all in one vita. A note of iconoclasm sounds throughout this intensely visual genre. Saints' lives are just as concerned with rendering their saints invisible as with bringing them into view. Moments of visual mortification reframe the more epiphanic moments, taking the mental gaze through a process of negation. This is the hagiographical mode's apophatic poetics.

\section{Affirmation, or Positive Cataphasis}

Hagiography has the task of manifesting holiness through aesthetic depiction, so its cataphatic strategies register immediately. Miracles, doves, miraculous lights, angelic intercession, voices from heaven - all of these positive, benign phenomena spring to mind when one thinks about the lives of the saints. Yet, as Peter Brown has noted, in late antique hagiography "the miracle story is often no more than a pointer" to the "hidden, intangible nucleus of power" latent in the holy person. ${ }^{94}$ Literature in the hagiographical mode functions as an imaginative prosthetic, helping readers to see invisible phenomena. In order to do so, it employs an abundance of signifiers.

Word pictures already possess the immaterial quality of being pure rhetoric. Yet precisely because of this rhetorical quality, they can conjure phantasmagorias difficult or impossible to represent with pigment or marble. ${ }^{95}$ Literature can bend the rules of materiality, indicating reality's spiritual dimension. The imagination troubles "the crucial boundary between things that 
exist objectively within the soul and those in the world outside." 96 The same faculty allowing spiritual and material to interact "uses similar attributes to make fictive worlds both alluring and meaningful.." ${ }^{97}$ Hagiography has the task of rendering the supernaturalism of the supernatural order, making it perceivable within the natural order. In order to make the marvelous appear marvelous, hagiography has to make it appear at all. Any phenomenon that has been artistically rendered joins the material realm by virtue of the pen, ink, pigments, marble, or parchment that disclose it. This physical necessity only reinforces the broader idea that the spiritual realm does interact with the material, and vice versa. Contemporary scholars of magical realism acknowledge that the mode's long history begins with "the masterful interweavings of magical and real in the epic and chivalric traditions," and we might easily add the hagiographical tradition, with its dragons, relics, and invincible virgins. ${ }^{98}$ These marvelous spectacles fill hagiographical prose not because the premodern world was a time of wonders, but because it had developed an aesthetic mode that assumed the reality of invisible phenomena and so attempted to manifest it in concrete, material detail.

Hagiographical affirmation, or cataphasis, invites the reader to see the world from a sanctified perspective. It insists on a more capacious reality than is readily apparent to the senses. Marion argues that only God can see the saints perfectly. Saints, who participate most deeply in the divine life, ostensibly see the world more clearly than other human persons. The hagiographical mode seeks to expand the aesthetic availability of invisible phenomena. Hagiography has the capacity to simulate saintly seeing, allowing readers a virtual experience of sainthood. Sometimes hagiography makes explicit the fact that to see a saint is to see as a saint. For example, Prudentius concludes his Passio Agnetis with a fantastical depiction of the cosmos. The vita does not end with Agnes's physical death. Rather, it reflects the theological notion that a 
saint's death-day is actually her natal, her birthday into heaven. Agnes leaps up into the ether. When she looks back down, everything becomes clear. She no longer sees through a glass darkly. Agnes possesses true perspective, literally and figuratively:

Now the disembodied spirit springs forth and leaps in freedom into the air, and angels are round her as she passes along the shining path. She marvels [miratur] at the world that lies beneath her feet; as she mounts on high she looks [spectat] at the darkness below and laughs at the circling of the sun's orb, the turning and intertwining of all the universe, the life that is lived in the black whirlwind of circumstance... All this Agnes tramples on and treads under foot... ${ }^{99}$

Prudentius depicts Agnes's transcendent wisdom by inviting his readers to see through her eyes. From her supernatural perspective, she can view and comprehend the mundane with absolute clarity. A saint is one who attains something of this perspective while still on earth, and seeing her involves seeing what she sees. Her proximity to the beatific vision gives her true insight into everything else. Contemplation of the saint should prompt one to follow her line of sight, to witness that to which she bears witness. The spectacle of sainthood signals the divine reality sustaining and enabling it. Theoretically, when saints fascinate in their own right, transfixing the gaze permanently, part of their message has been missed. Or rather, the ascent remains incomplete. Not wholly incomplete, though, since the phenomenon of sainthood reflects the holy's immanence within material reality. Hagiography assists in saintly recognition, allowing readers to "know" by looking "again" or "back at" (re-, cogitare) the phenomenon by way of aesthetic mediation. It prepares readers to get a read on saintliness as it occurs in lived reality. One does not identify sainthood as an ornithologist notes and collects birds. One enters into the state of being that sanctifies by training the gaze on God. 


\section{Defamiliarization: Violence and Monstrosity}

This process of making the invisible visible often requires a defamiliarization, estrangement, or deformation of everyday reality. These unlike renderings serve a larger reality (as opposed to unreality). They dramatically "show" (monstrare) that which would otherwise remain unseen. This monstrous showing is still a form of cataphasis, however mortified. I have called it negative cataphasis. It constitutes a partial negation: positive, cataphatic images become distorted so as to point beyond themselves. This component of hagiography's aesthetic consists of fantastic bouts of violence, pornographic interludes, literal monsters, and other displays of gross materiality.

It is a generic requirement that hagiographical protagonists suffer. Just as there is no way to the Father but through Christ, there is no way to Christ but through the Cross. Christian sanctity has an ethos of self-sacrifice. Hagiography developed an aesthetics of violence (whether literal or figurative) in its inception. Ekphrasis plays an enormous role in the earliest hagiographical texts, especially in homilies about the martyrs. Such language cultivates virtual spectatorship, exhorting hearers or readers to imagine their experience of violence as unmediated. The poetic quality of hagiographical ekphrasis both complicates and softens this injunction. For these images often possess a surreal, impossible quality, collapsing "the binary opposition between the natural, the organic, and the representational, on the one hand, and the spiritual, abstract, and symbolic or nonmimetic on the other." ${ }^{100}$ These word-pictures take the saints themselves as art objects, describing them as if they were already painted. They try to maintain the balance between the trauma of real suffering, which defies artistic rendering, and the transcendence insisted upon by theologies of martyrdom, which also resists aesthetic 
representation. Literary depictions of such spectacles explore the limits of artistic representation as such.

John Chrysostom (fourth-fifth c.) uses the ekphrastic technique in his sermon "On the Holy Martyrs." He moves fluidly from realist to figural description. Both modes of description interpenetrate one another until the distinctions break down. At one moment, he lifts the veilalways rhetorically — on the brutality that the martyrs faced, describing the torture as an immediate spectacle: "And one could see cavities exposed, ribs opened up, spines shattered... And again one could see sights more cruel than before-two drips coming down out of the bodies, the one of flowing blood, the other of melting flesh."101 These startling images of bodily fragmentation serve a memorializing function. Though sporadic, persecutions were remembered obsessively by early Christian communities. Art served as both a mneumonic and an interpretive device, imbuing victimhood with sacrificial meaning. Martyrs emerge as martyrs ("witnesses") only when beheld by a certain kind of gaze, one willing to witness the process of witness. Ekphrasis exposes the hidden glory to which the martyr bears witness, but the paradoxical tension between violent defeat and transcendent victory remains. John poeticizes the carnage, lacing it with light imagery: "Have you often seen the sun coming up just before dawn and emitting saffron-colored rays? The saints' bodies were like that, seeing that torrents of blood flowed around them in every direction, like some saffron-colored rays, and illuminated their bodies far more than the sun does the sky." ${ }^{\prime 102}$ He invites hearers to see the sun in the martyrs, the martyrs in the sun, producing an image nearly impossible to depict in pigments. His conceit estranges both tenor and vehicle. The ruddiness of both images suggests real similitude, but what does it mean for a viscous, single-toned liquid to resemble beams of light? Indeed, tenor and vehicle become difficult to distinguish, since Chrysostom begins his comparison with the sun. 
Are the saints' bodies like the sun, or is the sun like the saints' bodies? The image destabilizes hearers' attempts to envision the scene of martyrdom, simultaneously raising them above its hard, material reality. Negative cataphasis is not restricted to depictions of violence.

The hagiographical mode often utilizes monsters as a means both of gesturing toward divinity and effecting the protagonist's sanctification. Many saintly protagonists encounter monsters before receiving a more direct and positive sign of grace. They must decode the monster's significance before further sanctification can occur. As we have seen, hagiography invites its readers to follow the saintly gaze. If monsters cue a certain response from the saint, the reader should echo this response virtually. Monsters signal to the reader that reality extends far beyond his capacity to understand it. They function "as triggers for ontological enquiries," providing "a way of mediating the middle ground between human and divine." 103 They always point toward something else, as the etymology of the word suggests. "The monster is definitionally a displacement: an exhibit, demonstrative of something other than itself."104 As such, it confronts the reader with an imperative: read me. This command remains whether the monster proves legible or not.

St. Christopher affords the most famous example of saintly monstrosity. His legend makes explicit the monstrous implications of sanctity because the monster himself becomes the saint. In Western versions, Christopher is a giant who carries the Christ-child across a river. In earlier, Eastern versions, he takes the form of a cynocephalus. He appears first in fifth-century Nestorian apocryphal acts of Andrew and Bartholomew. In the fourteenth-century Ethiopic Gadla Hawâryât (Contendings of the Apostles), Christopher belongs to a monstrous, cannibalistic race. The Angel of God appears to him, commanding that he assist the apostles in their evangelizing mission. He protests, "O my Lord, I am not like all the other men, and I have 
no knowledge of their speech... And if I be hungry, where shall I find men to eat?" 105 From the monster's mouth comes the idea that monstrosity somehow resists intelligibility. Only when ordered to the divine does the monster begin to disclose its meaning. God frees the dog-headed man of his bestial nature, preserving only the human component. The dog-headed man also receives the ability to speak in the human tongue. The monstrous visage, however, remains:

Now his appearance was exceedingly terrible. He was four cubits in height and his face was like unto that of a great dog, and his eyes were like unto lamps of fire which burned brightly, and his teeth were like unto the tusks of a wild boar, or the teeth of a lion, and the nails of his hands were like unto curved reaping hooks, and the nails of his toes were like unto the claws of a lion... and his whole appearance was awful and terrifying. ${ }^{106}$

Wherever Christopher goes, he startles or terrifies people into conversion. His face arrests the gaze. On one level, this monstrosity is an Orientalizing move meant to other then coopt the nonChristian peoples whom evangelists encountered. Downplaying the problematic function of monstrosity in the vitae of St. Christopher would be a mistake. Overemphasizing it, however, risks undermining the cultural potency of those same non- and pre-Christian civilizations. The cynocephalus represented divine power, inspiring the mysterium tremendum, long before the birth of Christ. Most Christian saints associated with dogs have their feasts during the "dog days," when the constellation Sirius is ascendant. Sirius has a long history, one extending past ancient Greco-Roman culture to the jackal-headed god Anubis. ${ }^{107}$ One might find other examples of saints with ghastly visages and pagan origins. St. Bridget of Kildare (fifth-sixth c.) asks God to dissuade her suitor, so he causes one of her eyes to pop out and hang loose. This thoroughly disgusts the would-be husband. Brigid's spontaneous deformation may derive from a detail in the Ulster Cycle. The epic hero Cú Chulainn undergoes a similar deformity when possessed by the frenzy of battle. ${ }^{108}$ In both cases, hagiography absorbs and reinterprets pre-Christian topoi. Incorporating a cynocephalus into the hagiographic pantheon served an iconotropic function, 
allowing Christians to harness and redirect traces of divine awe attached to the figure. The dogheaded man was too striking a character simply to eradicate. Christians needed to watch his "passage from monstrous hybridity to saintly singularity"; Christopher "commenced his life as a monster and at his death was transfigured into an icon, endlessly painted on medieval town walls to bless passing travelers." 109

The monstrosity of sainthood has its roots in Christ's own ineffable person. Attempts to represent God, whether as the Trinity or as the incarnate Second Person, often devolved into the monstrous. These grotesqueries might provide valuable instruction about the divine, as PseudoDionysius would certainly argue, but what happens when they fail? Defamiliarization, or negative cataphasis, risks misrepresenting the divine, producing artistic heresies. Theologians decried the three-headed Trinities found in sculpture and paint. ${ }^{110}$ Not only did they make God himself look monstrous, they presumed to represent the invisible Father and could suggest either modalism or tritheism, depending on how one looked at them. Many scholars, both contemporary and medieval, have imagined Christ's body as monstrous. Robert Mills has noticed and analyzed a cruciform body with a bird's head found in an early fourteenth-century English Book of Hours. ${ }^{111}$ In his Topography of Ireland, Gerald of Wales (twelfth-thirteenth c.) betrays a "sense that the classifications and category crises provoked by Christ's body may be compared, however awkwardly, with wonders of nature like werewolves and Augustine's monstrous races." 112 In many illuminated sacred texts, such as the Book of Kells, "the Word of God itself became 'a habitation of dragons." ${ }^{113}$ Despite the Pseudo-Dionysian defense of unlike images, the threat of their failure always remains. One might not ascend beyond the grotesque, transfixed by the Gorgon's gaze. 


\section{Pure Negation: The Irregardable Saint}

The hagiographical mode may delectate in its cataphatic images, but it also endeavors to push readers beyond sensual and conceptual experience altogether. Of course, being an artistic medium, hagiography can never do this entirely. Yet it can simulate the final stage of apophatic negation, exhorting readers to question and transcend their own sensual and intellectual gazes. ${ }^{114}$ In addition to blurring the line between spiritual and material manifestation, the hagiographical mode occasionally works to undermine the gaze entirely. It does this by depicting bystanders as going blind, by eclipsing the saint's body with another entity (i.e., constructing a scene in which she is present but inapparent), by allowing others to mistake the saint for someone else, and by describing her with grammatical negatives. All of these topoi constitute the heart of hagiography's apophatic poetics.

It seems tempting to call these instances of saintly invisibility. Yet, as mentioned, the presence of a vita before the reader's eyes (or mind) keeps the saint from disappearing altogether. I prefer a less stark term, borrowed from Marion's "Sketch of the Saturated Phenomenon": irregardability. This word maintains the saint's presence and reality while emphasizing her ability to repel the gaze. It describes not absence, but a kind of supermanifestation. The saint repels the gaze not because there is nothing to see, but because there is too much. The mind's eye rolls off of her as it would the sun. "Determining the saturated phenomenon as irregardable amounts to imagining the possibility that it imposes itself on sight with such an excess of intuition [i.e., in-flowing phenomenality] that it can no longer be reduced to the conditions of experience." "Saturated phenomena" (for our purposes, saints) cannot be experientially reduced, or "led back," in the way that regular objects can. Marion acknowledges that this seems to imply impossibility of experience. He insists that the phenomenon "is 
nevertheless seen, but as blurred by the too narrow aperture, the too short lens, the too cramped frame, that receives — or rather that cannot receive it as such." ${ }^{116}$ Rather than enjoying an easy spectacle, the eye sees primarily its own impotence and inadequacy. The direction of experience has been reversed, producing a "counter-experience." 117 This parallels his claim in "The Invisibility of the Saint" that those of a higher order perceive those of a lower order, but not vice versa. The saturated phenomenon constitutes the perceiving subject as a "witness," rather than allowing itself to be constituted as an object. ${ }^{118}$ This works for Marion because the saturated phenomenon par excellence is God. Other phenomenologists have accused Marion of doing theological work under the guise of philosophy. Whether valid philosophy or not, Marion's categories lend themselves beautifully to an analysis of hagiography, a theologico-imaginary discourse that attempts to portray the elusive phenomenon of holiness.

The most straightforward instance of saintly irregardability involves the topos of blindness. In the Passio Agnetis, the virgin's gaze encompasses the entire world, but how does the world view her? In terms of her sainthood, the world cannot see her at all. Once she refuses to recant, the justice has her placed in the midst of a public square, vulnerable to any who wish to defile (polluere) her. ${ }^{119}$ Her exposure produces two reactions, both of which mortify the gaze. Perhaps counter-intuitively, her shame is transferred to the bystanders. Their inability to raise their eyes to her-to "face" her-betrays this. Though they have placed her there in the first place, "the crowd avoided her in sorrow, turning their faces away [aversa vultus] lest any look [conspiceret] too rudely on her modesty." ${ }^{120}$ At her moment of maximal exposure, Agnes becomes least regardable. Agnes is most conformed to Christ during this nadir. As with Christ, however, her glory becomes least apparent at the height of her sanctity. What happens when one individual looks on her with boldness? One man does indeed aim (intendit) an "impudent gaze" 
(procaciter os) at the saint. ${ }^{121}$ Prudentius uses the verb intendere to describe the process by which one directs a gaze. This literary moment anticipates contemporary phenomenology, providing it with some interesting prehistory. Classical phenomenology also describes the outward thrust of perception as "intentionality." The man's wrongheaded intentionality rebounds, to his detriment. After training his gaze on her, "a fire came flying like a thunderbolt and with its quivering blaze struck his eyes, and he fell blinded by the gleaming flash."122 This fantasy of counter-experience imagines that holiness blots out the gaze that fails to recognize itand, paradoxically, to recognize is to avert one's eyes in humility. The rest of the crowd reacts appropriately, voluntarily lowering its collective gaze. The youth who fails to do so has his gaze lowered for him. Prudentius implies, though he does not explicitly state, that Agnes is naked. Yet the vita concerns itself less with whether the bystanders (or readers) see (or envision) her form than it does with how they do so. The vita teaches recognition by blotting out a character's gaze entirely, by extension exhorting readers to ascend beyond their imagistic proclivities as well. The counter-experience reduces the lusty onlooker to a "prostrate sinner" (reo iacenti, or "cast-down guilty party"); he has undergone conversion, a turn-about enabled by his time in darkness. Agnes then restores his sight, giving him "perfect vision" (visus integer). ${ }^{123}$ The experience, or counterexperience, of saintly irregardability has trained and perfected the character's gaze.

Theoretically, it has improved the reader's mental gaze as well. The narrative concludes with a vision that perfect gazing might yield: Agnes's heaven-centric contemplation of the cosmos. The reader enjoys a virtual experience of saintly gazing, seeing through her eyes.

Striking a character blind does not remove the saint from the reader's own mental gaze, so sometimes the hagiographical mode hides her even from virtual sight. In the South English Legendary "Life of Saint Margaret," the dragon episode leads directly to a moment of holy 
eclipse, following the Pseudo-Dionysian stages of apophasis from monstrosity to pure negation. The dragon "forswolwyde" ("swallowed") Margaret whole, so that "Heo wende [went] into a sori wombe." ${ }^{24}$ If one envisions this scene accurately, Margaret does not appear within it. The dragon's flesh cloaks her. Despite the hagiographer's doubt about its verity, and despite the saint's seeming absence, this episode defines the legend of St. Margaret. It associates her with childbirth, and many illuminations depict the spectacular scene of eruption. The reader cannot regard her at this moment pre-eruption, yet it proves the crux of her trial. Her descent into the beast's gullet parallels Christ's descensus ad inferos. Many illuminations of the Harrowing render hell as a monstrous maw out of which he leads those trapped in the beast's belly. The saint joins Christ in this moment of supreme absence and abjection, and we cannot follow her there.

The hagiographical mode also renders a saint irregardable by means of traditional apophasis: the negating of positive statements. Once again, the SEL "Margaret" contains a vivid example of this. Before she encounters the dragon, Margaret endures so much fragmentation that her "gottes [guts] isene were."125 The justice, who has commanded "pat me hure gottes iseo," finds his gaze bent backward once he has obtained this sight. ${ }^{126}$ The SEL offers a naturalistic version of the miraculous blindness found in earlier legenda. The sight of so much gore overcomes him, and he averts his gaze. The justice does not look away simply from shame, since he is one of the few characters who resists conversion. Rather, the act of looking becomes negated; his gaze is repulsed by a force beyond his control. Margaret's irregardability forces his intentionality away. The hagiographer signals this by grammatically negating the looking verbs: “nolde loky" (“couldn't look"), "nemizte for deol it iseo" (“couldn't see it, for sorrow”), "neseie" ("not see it"), "He nemizte hire for deol iseo" ("He couldn't see her, for sorrow"). ${ }^{127}$ The 
hagiographer also signals this irregardability through the justice's physical actions: “Ac bihuld abac and hudde is eizen" ("But he looked away and hid his eyes"). ${ }^{128}$ At one point, he covers his face "Wip is mantel [cloak]." ${ }^{129}$ At the same time all of this non-looking occurs, the hagiographer also tells us about the piteous gore that the justice beholds, and that repels his gaze. Is he looking and seeing, looking and not seeing, or not looking at all? It remains unclear. The hagiographer describes the sight for the reader's benefit, but does that mean the justice beholds those details as well? The justice completes this irregardability by sending Margaret off to a deep, dark dungeon. While her tormentors squint at her fragmented body, Margaret "caste up hure eize [eyes]."130 This seems to indicate a strong-willed meeting of her accuser's feeble gaze, yet the upward gaze ascends even farther. Right before her execution, Margaret utters a final prayer. Readers and onlookers know she prays because "to heuene hure eizen caste."131 The saint looks to God, while those who refuse to recognize her fail to see anything at all.

\section{Learning to Read the Saints}

In some mysterious way, the very idea of sanctity presumes a degree of hiddenness. The humblest saints, after all, must remain unknown and unhonored. From late antiquity to today, Christian thinkers have continually affirmed the existence of anonymous saints. These nameless saints fuel the devotee's hope of heaven. Their glorious obscurity reassures believers that anyone might be a saint. As Marion points out, only God knows for sure-only the shepherd knows his flock. When the church canonizes a saint, it claims merely to have identified an individual who definitely enjoys the beatific vision. The official pantheon by no means excludes those who have not received recognition. The triptych of All Hallow's Eve, All Saints Day, and All Souls Day (Oct. 31-Nov. 2) best honors and articulates the idea of saintly anonymity. In the Legenda aurea, Jacobus de Voragine outlines the reasons for celebrating All Saints. One reason is "to supply for 
the omission of many saints from the calendar," and another is "to atone for neglect in honoring the saints." 132 Whether a saint goes without honor because Christians have forgotten her or because they never knew her in the first place, All Saints covers such omissions through mass homage. What seems a lack actually signifies abundance. Jacobus insists that "we could not have feasts for all the saints" because "the number of them has multiplied until it is almost infinite."133 One wonders if any have died who are not saints, which is exactly the point. All Saints always points to All Souls, which immediately follows. Whereas Christians pray to the holy dead, they pray for all the other dead. Yet the boundary between these two feasts is wonderfully blurred. Karl Rahner notes that "we do not know precisely where the dividing line falls between All Saints and All Souls," which unites the feasts in a "common meaning." 134 One person's beloved dead might be another's anonymous saint.

Perhaps sainthood is not so much recognizable as it is legible, for the written word hides even as it discloses. The black marks are not the referents themselves, yet they point the way. Sainthood is a phenomenon to be read. Hagiography responds to this reality, transcribing and recreating the phenomenon in order to enhance saints' legibility. Drawing implicitly on a long apophatic tradition, Marion calls sainthood “formally invisible." Holiness, God's ineffable core, certainly retains its ineffability. But sainthood? Sainthood is holiness in motion, active and incarnate. The form of the holy might be invisible, hiding the ontological core of sainthood from view. Yet form also has an irreducibly aesthetic component. As a living art form, the lives of the saints do not withhold themselves. Quite the contrary: they give themselves in the mode of witness. One thinker has said that sainthood means living "in such a way that one's life would not make sense if God did not exist." "135 Saintly lives aim to embody and incarnate some portion of the divine Logos. They have a logic and a grammar, however otherworldly. Saints write 
themselves into a larger narrative both theologically and literally. They are creatures of scripture, and of each others' vitae. A recurring motif "in their stories is the importance of an encounter with another saint — sometimes in person, but often through reading a story or hearing a legend."136 Athanasius's "Life of St. Anthony" inspired a young Augustine. Margaret converts after hearing the passions of Sts. Stephen and Lawrence. Jesus himself survived as gospel—as story-long after his body suffered ignominious death and promptly disappeared. The first saints entered "in a graphic way into the dying of Jesus... They were icons of Jesus Christ, awesome signs of the victory of his power." Elizabeth Johnson refers to this as the "christic pattern" that saints' lives assume. ${ }^{137}$ Yet the very idea of a christic pattern contains a paradox. The vita Christi shows forth an image of defeat and seeming meaninglessness. Subject to similar fragmentation and abjection, the first saints imitated the pattern in a literal manner.

Hagiography attempts to pick up the pieces, reassembling them into a "useable story."138 Its creative project reveals latent or lost meanings by inscribing individual lives into the narrative of salvation history. The beginning and end of this story exceed visible reality, so learning to read entails learning to see the invisible. The Liber Peristephanon of Prudentius affords a final example. The passion of St. Hippolytus contains an emergent theory of hagiography. Roman officials devise a grim death for Hippolytus (second-third c.), sentencing him to be pulled apart by horses. This gruesome execution scatters his body and blood across the landscape. Flesh "hangs from the top of rocks, some sticks to bushes, with some the branches are reddened, with some the earth is wet." ${ }^{\prime 139}$ Metacritical about his craft, Prudentius reveals the architectonics of his saint-writing buried within the phenomenon of sainthood itself. Sainthood is autohagiographical, always writing itself, though "unaware of itself." ${ }^{140}$ Prudentius compares the blood to ink: purpureas... notas vepribus inpositas. H. J. Thomson translates this, “[I saw the...] 
scarlet stains imprinted on the briers." ${ }^{" 141}$ A more literal translation draws the metaphor out further: "purple-red marks/signs put on the thorn bush." This ekphrastic meditation slips fluidly from image to event. Prudentius recounts the devotees' attempts to collect the scattered limbs and fragments of flesh. They sop up the blood with their garments. He uses the verb legere to capture this image of gathering. Taking advantage of the verb's literal sense, "to gather," he also implies the priority of its second meaning, "to read." ${ }^{142}$ Hippolytus writes his own vita well before Prudentius puts ink to parchment. The "ought to be read" of legendum applies originally to the actual life, secondarily to the textual life. Yet, for most, this act of reading can only occur by way of text. The text is an extension of the biological life. To see a saint is to read. To read is to discern a meaningful whole where only chaotic fragments appear. The first followers of Hippolytus anticipated the act of reading in their gathering up his broken body. For Prudentius, the very first instant of mourning contains the seeds of legend. Memorialization insists on the meaning of an individual's life. Gathering up and recalling one's holy dead constitutes a process of meaning-making, of poesis. Meaning already suffuses all lives. The process of writing simply recaptures it. One theologian goes so far as to argue that "the first task of the Christian tradition is to tell their [the martyrs'] story." ${ }^{143}$

The same logic applying to individual lives applies to the whole as well. In a miraculous paradox, the totality of holy lives yields one body. How do saints retain their individual geniuses while conforming to the christic pattern? How to gather the members together into one body so that what one ultimately reads is the Logos itself? The "resemblance is something we learn to see... The kinship of sainthood is first of all a set of relationships to God... The unmanageable diversity of the saints is a conceptual problem for $u s$, but in practice it is a wonder of grace."144 Theologically, saints' family resemblances to one another stem from their relationship to God. 
The relationship between saint and devotee is always triangulated. A multitude of stories amounts to one tale. This has a generic truth to it as well, as hagiographers produced and conformed to literary templates, such that many saints became interchangeable with others of the same type. Saints' lives retell the gospel over and over, always remaking it anew. Just as the saints assume Christ's form by inhabiting his story, so can readers of hagiography join the saintly fellowship by inhabiting their vitae. Allowing a saintly exemplar to transform one amounts to joining the body. Communion enables one to approach the saint relationally, through a loving intention of the will, as opposed to just conceptually. Hagiography provides a laboratory within which to exercise and perfect this love. "To paint, to narrate, the artist, the writer, must be able to see not only with the eyes, but with the heart." ${ }^{" 145}$ The same goes for the reader. The communion of saints opens up a space "in which forgotten stories are told, hope engendered, solidarity enhanced." 146 Tale-telling is an intrinsically communal activity. It presumes the possibility of communicating meaning by way of aesthetic mediation. The hagiographical mode underwrites this communication with the promise of communion. Against the abyssal white of a blank page, the dark grows luminous. It shines forth with the promise of meaning, shaped, hewn, and harbored by the void.

\section{Notes}

${ }^{1}$ Jean-Luc Marion, “The Invisibility of the Saint," trans. Christina M. Gschwandtner, Saints: Faith Without Borders, ed. Françoise Meltzer and Jaś Elsner (Chicago: University of Chicago Press) 355 .

${ }^{2}$ Peter Brown, "The Rise and Function of the Holy Man in Late Antiquity," The Journal of Roman Studies 61 (1971): 91. 
${ }^{3}$ Textual accounts of holy individuals appear in many cultures and religions. Hindu swamis and Sufi mystics, for example, appear in texts as well as life. Western scholars often use the word "hagiography" with reference to such writings, but theological differences between religions makes this risky. Using the term indiscriminately elides cultural difference even as it flags striking parallels. In some cases, however, different religions share a holy person in common. Both Islam and Christianity share the cult of Mary, mother of Jesus. In such cases, it becomes possible to speak of a common "hagiographical" tradition. By force of necessity, this project limits its focus to Western hagiography in the Christian tradition, specifically that of thirteenth- and fourteenth-century England, although I do draw on late antique Greco-Roman lives for context; Robert Bartlett, Why Can the Dead Do Such Great Things? Saints and Worshippers from the Martyrs to the Reformation (Princeton: Princeton University Press, 2013): “[Attempting to cover hagiography's globality can take a project] from being understandably over-ambitious to being absurdly over-ambitious" (xvii).

${ }^{4}$ Thomas Head, ed., "Introduction," Medieval Hagiography: An Anthology (New York: Routledge, 2001) xiv; Derek Krueger, Writing and Holiness: The Practice of Authorship in the Early Christian East (Philadelphia: University of Pennsylvania Press, 2004) 5.

${ }^{5}$ Bartlett 21.

${ }^{6}$ Mary-Ann Stouck, ed., Medieval Saints: A Reader (Peterborough, Ontario: Broadview Press, 1999) xvii.

${ }^{7}$ Krueger 6 .

${ }^{8}$ Head xiv.

${ }^{9}$ Unless otherwise indicated, all biblical citations within this introduction are from The New American Bible, Revised Edition. 
${ }^{10}$ Gerald A. McCool, “The Philosophical Theology of Rahner and Lonergan,” God, Knowable and Unknowable, ed. Robert J. Roth, S.J. (New York: Fordham University Press, 1973): “...God is Pure Act, the Infinite Prime Mover whose causal influence is required to ground the movement of the human spirit... The attributes through which He is defined are rooted in being rather than process. They are identical, in fact, with the traditional attributes assigned to divinity by Aquinas. God is ipsum intelligere, ipsum esse, summum bonum, the exemplar, the efficient cause, first agent, and last end of all that is or could be" (123).

${ }^{11}$ Thomas Aquinas, Summa Theologiae, ed. and trans. Timothy McDermott, O.P., vol. 2 (London: Blackfriars, 1964) 83. I, Q. 6, Art. 1.

12 Patrick Sherry, Spirits, Saints, and Immortality (Albany: State University of New York Press, 1984): “The term 'holy' nowadays tends to have almost purely ethical connotations. The biblical term qadosh, however, originally had a much richer depth of meaning than this, for holiness was ascribed to people (and to places, sacred vessels and so on) in virtue of being set apart in relationship to God..." (31).

${ }^{13}$ Marion, "The Invisibility of the Saint" in Elsner and Meltzer, eds., Saints: Faith Without Borders 360.

${ }^{14}$ See Samuel E. Balentine, The Hidden God: The Hiding of the Face of God in the Old Testament (Oxford: Oxford University Press, 1983); J. L. Schellenberg, Divine Hiddenness and Human Reason (Ithaca: Cornell University Press, 2006).

${ }^{15}$ Paul K. Moser, “Cognitive Idolatry and Divine Hiding,” Divine Hiddenness: New Essays, ed. Daniel Howard-Snyder and Paul K. Moser (Cambridge: Cambridge University Press, 2002): "One of Jesus's disciples asks why he will not manifest... himself to the world... The disciple's thinking is familiar: why hide from the world if you have miraculous powers? ...The 
Jewish-Christian God is anything but epistemologically ‘safe,' or controllable. We cannot control either God or God's hiding on occasion... God reveals God on God's gracious terms, as a gift, rather than on our self-crediting terms. Some widely favored epistemological conditions for God involve displays of miracle, power, and sophisticated wisdom. Such conditions amount to a triumphalist epistemology that readily promotes self-exaltation instead of God's humble love" (139).

${ }^{16}$ Marvin Meyer, The Gnostic Gospels of Jesus: The Definitive Collection of Mystical Gospels and Secret Books about Jesus of Nazareth (New York: Harper Collins, 2005) xiv; See also Michael Allen Williams, Rethinking Gnosticism: An Argument for Dismantling a Dubious Category (Princeton: Princeton University Press, 1996); Alastair Logan, The Gnostics: Identifying an Early Christian Cult (London: T\&T Clark, 2006).

${ }^{17}$ See Morton Smith, Jesus the Magician (New York: Barnes and Noble Books, 1978).

${ }^{18}$ John Parker, The Aesthetics of Antichrist: From Christian Drama to Christopher Marlowe (Ithaca: Cornell University Press, 2007) x.

${ }^{19}$ See Candida Moss, The Other Christs: Imitating Jesus in Ancient Christian Ideologies of Martyrdom (Oxford: Oxford University Press, 2012).

${ }^{20}$ Rudolf Otto, The Idea of the Holy, trans. John W. Harvey (Oxford: Oxford University Press, 1958): "We generally take 'holy' as meaning 'completely good'; it is the absolute moral attribute, denoting the consummation of moral goodness... But this common usage of the term is inaccurate" (5); Susan Wolf's essay "Moral Saints" has sparked an interesting conversation about this exact issue. In it, she equates sainthood with moral perfection. Robert Adams answers her directly in The Virtue of Faith and Other Essays in Philosophical Theology, emphasizing the supernatural and non-pragmatic aspects of sainthood. Discussions of postmodernism sometimes 
turn to saints as exemplars of an acceptable ethics. Edith Wyschogrod's Saints and Postmodernism affords one example. This conception of sainthood as pure ethics would have been foreign to medieval thinkers. See Susan Wolf, "Moral Saints," The Journal of Philosophy 79 (1982): 419-439; Robert Merrihew Adams, The Virtue of Faith and Other Essays in Philosophical Theology (Oxford: Oxford University Press, 1987); Edith Wyschogrod, Saints and Postmodernism: Revisioning Moral Philosophy (Chicago: University of Chicago Press, 1990). ${ }^{21}$ Marion, "The Invisibility of the Saint” in Elsner and Meltzer, eds., Saints: Faith Without Borders 355. Marion is building here on Henry's concept of invisibility. (See note 33.) ${ }^{22}$ Petra Turner, “The Unknown Saint: Reflections on Jean-Luc Marion’s Understanding of Holiness," The Postmodern Saints of France: Refiguring 'the Holy' in Contemporary French Philosophy, ed. Colby Dickinson (London: T\&T Clark, 2013) 231.

${ }^{23}$ Marion, "The Invisibility of the Saint" in Elsner and Meltzer, eds. Saints: Faith

Without Borders 356

${ }^{24}$ Otto 12.

${ }^{25}$ Marion, "The Invisibility of the Saint: in Elsner and Meltzer, eds. Saints: Faith Without Borders 356.

${ }^{26}$ Marion, "The Invisibility of the Saint” in Elsner and Meltzer, eds. Saints: Faith Without Borders 357.

${ }^{27}$ Marion, “The Invisibility of the Saint” in Elsner and Meltzer, eds. Saints: Faith Without Borders 361.

${ }^{28}$ Marion, "The Invisibility of the Saint" in Elsner and Meltzer, eds., Saints: Faith Without Borders 362. 
${ }^{29}$ Turner, "The Unknown Saint" in Elsner and Meltzer, eds., Saints: Faith Without

Borders 235.

30 Turner, "The Unknown Saint" in Elsner and Meltzer, eds., Saints: Faith Without Borders 239.

${ }^{31}$ Turner, "The Unknown Saint" in Elsner and Meltzer, eds., Saints: Faith Without Borders 243.

${ }^{32}$ Turner, "The Unknown Saint" in Elsner and Meltzer, eds., Saints: Faith Without Borders 243.

${ }^{33}$ Jacobus de Voragine, The Golden Legend, trans. William Granger Ryan (Princeton: Princeton University Press, 2012) 660.

${ }^{34}$ Krueger 6.

${ }^{35}$ Sherry $1-3$.

${ }^{36}$ Kevin Hart, Poetry and Revelation (London: Bloomsbury, 2016), chapter five (forthcoming). Note Three: "Husserl an von Hofmannsthal (12. 1. 1907)," Briefwechsel, 10 vols: Wissenschaftlerkorrespondenz, ed. Elisabeth Schuhmann and Karl Schuhmann (Boston: Kluwer, 1994) 7:135.

${ }^{37}$ See Michel Henry, Seeing the Invisible, On Kandinsky, trans. Scott Davidson (New York: Continuum, 2009) 3, 13.

${ }^{38}$ E. P. Sanders, The Historical Figure of Jesus (London: Penguin, 1995$) 85$.

${ }^{39}$ See Bruce Holsinger, "Parchment Ethics: A Statement of More than Modest Concern," New Medieval Literatures 12 (2010): 131-136.

${ }^{40}$ Krueger 4.

${ }^{41}$ Bartlett 519. 
42 Bartlett 519.

${ }^{43}$ Patricia Cox Miller, The Corporeal Imagination: Signifying the Holy in Late Ancient Christianity (Philadelphia: University of Pennsylvania Press, 2009). Patricia Cox Miller refers to "the invisible bodies of the saints in hagiography," arguing that saints' lives develop a corporeal poetics in order to make those bodies manifest (8).

${ }^{44}$ Krueger 133.

${ }^{45}$ Krueger 133.

${ }^{46}$ Peter Brown, The Cult of the Saints: Its Rise and Function in Latin Christianity (Chicago: University of Chicago Press, 1982) 87.

${ }^{47}$ Brown, The Cult of the Saints 88.

${ }^{48}$ Virginia Burrus, Saving Shame: Martyrs, Saints, and Other Abject Subjects (Philadelphia: University of Pennsylvania Press, 2008): "Here we view four well-knownindeed, virtually classic_-literary performances of Christian witness..." (19, emphases added); "Writers and readers of ascetic literature, like the persistent pilgrims crying at the doorway or peering into the chinks of an ascetic's cell, are thus positioned as so many 'peeping Toms, ' and the writers of travelogues and hagiographies not only frequently betray awareness of the ocular transgression inherent to their literary endeavors but also sometimes seem to exult in the very shamelessness of these acts of exposure" (36, emphases added); Elizabeth A. Castelli, Martyrdom and Memory: Early Christian Culture Making (New York: Columbia University Press, 2004): “...the cultural production of Christian martyrdom as performance and spectacle transforms the seer into the seen... And it transforms the readers and consumers of this tradition into uneasy voyeurs of the suffering of others..." (133, emphases added) 
${ }^{49}$ Caroline Walker Bynum, The Resurrection of the Body in Western Christianity, 200-

1336, Lectures on the History of Religions 15 (New York: Columbia University Press, 1995):

“...Christians did worry passionately about the bodies of the martyrs" (49).

${ }^{50}$ See Candida Moss, The Myth of Persecution: How Early Christians Invented a Story of Martyrdom (New York: HarperCollins, 2013).

${ }^{51}$ See Larissa Tracy, Torture and Brutality in Medieval Literature: Negotiations of National Identity (Cambridge: D.S. Brewer, 2012).

${ }^{52}$ See Ron Eyerman, Cultural Trauma: Slavery and the Formation of African American Identity (Cambridge: Cambridge University Press, 2001) 2.

${ }^{53}$ Castelli: "Indeed, one might argue that the capriciousness of state violence- - the mere presence of the imperial judicial apparatus with its omnipresent threat of violence, whether or not it was actually carried out—-performed a critical kind of psychological work for all manner of subjected peoples, Christians included" (38).

${ }^{54}$ Castelli 29; See also Richard A. Bauman, Crime and Punishment in Ancient Rome (New York: Routledge, 1996); Richard C. Beacham, Spectacle Entertainments of Early Imperial Rome (New Haven: Yale University Press, 1999); G. W. Bowersock, Martyrdom and Rome (New York: Cambridge University Press, 1995); Alison Futrell, Blood in the Arena: The Spectacle of Roman Power (Austin: University of Texas Press, 1997); Ed. Ralph Jackson, Gladiators and Caesars: The Power of Spectacle in Ancient Rome (London: British Museum Press, 2000); Donald G. Kyle, Spectacles of Death in Ancient Rome (New York: Routledge, 1998); Thomas E. Wiedemann, Emperors and Gladiators (London: Routledge, 1992); Magnus Wistrand, Entertainment and Violence in Ancient Rome: The Attitudes of Roman Writers of the First Century A.D. (Göteburg: Acta Universitatis Gothoburgensis, 1992); Paula James, 
"Prudentius' Psychomachia: The Christian Arena and the Politics of Display," Constructing Identities in Late Antiquity, ed. Richard Miles (London: Routledge, 1999) 74.

${ }^{55}$ Michael Camille, The Gothic Idol: Ideology and Image-Making in Medieval Art, Cambridge Studies in New Art History and Criticism (Cambridge: Cambridge University Press, 1991) 19.

${ }^{56}$ James 75.

${ }^{57}$ James 75 .

${ }^{58}$ Miller, The Corporeal Imagination 7.

${ }^{59}$ Miller, The Corporeal Imagination 7.

${ }^{60}$ Camille, Gothic Idol 222.

${ }^{61}$ Camille, Gothic Idol 240-1.

${ }^{62}$ Henri Joly, The Psychology of the Saints (Fort Collins, CO: Roman Catholic Books)

22. (First pub. 1898).

${ }^{63}$ Denys Turner, "Apophaticism, Idolatry and the Claims of Reason," Silence and the Word: Negative Theology and Incarnation, ed. Denys Turner and Oliver Davies (Cambridge: Cambridge University Press, 2008) 23.

${ }^{64}$ See Filip Ivanović, Symbol and Icon: Dionysius the Areopagite and the Iconoclastic Crisis (Eugene, OR: Pickwick Publications, 2010).

${ }^{65}$ The authority inspired by the pseudonymous identity (that of Dionysius, a convert of Paul in Acts) gave the Mystical Theology a kind of precedence over Gregory of Nyssa's earlier apophaticism.

${ }^{66}$ Pseudo-Dionysius, "The Mystical Theology” in Pseudo-Dionysius: The Complete Works, ed. John Farina, trans. Colm Luibheid (New York: Paulist Press, 1988) 138, 139. 
${ }^{67}$ Camille, Gothic Idol.

${ }^{68}$ Pseudo-Dionysius, “The Mystical Theology” 138.

${ }^{69}$ See Kenneth Gross, The Dream of the Moving Statue (University Park: Penn State Press, 2006).

${ }^{70}$ Deirdre Carabine, The Unknown God: Negative Theology in the Platonic Tradition:

Plato to Eriugena, Louvain Theological \& Pastoral Monographs Ser. 19 (Louvain: Peeters Press, 1995) 301.

${ }^{71}$ Gregory Telepneff, The Egyptian Desert in the Irish Bogs: The Byzantine Character of Early Celtic Monasticism (Etna, CA: Center for Traditionalist Orthodox Studies, 2002).

72 Timothy Ware, The Orthodox Church (London: Penguin, 1993) 63.

${ }^{73}$ Quoted in Ware 63.

${ }^{74}$ The Cloud of Unknowing, TEAMS Middle English Texts Series, ed. Patrick J.

Gallacher (Kalamazoo: Medieval Institute Publications, 2005) 34-5.

${ }^{75}$ Patricia Cox Miller, "Subtle Embodiments: Imagining the Holy in Late Antiquity," Apophatic Bodies: Negative Theology, Incarnation, and Relationality, ed. Chris Boesel and Catherine Keller (New York: Fordham University Press, 2009) 45.

${ }^{76}$ Miller, "Subtle Embodiments: Imagining the Holy in Late Antiquity" in Boesel and Keller, eds., Apophatic Bodies: Negative Theology, Incarnation, and Relationality 45.

${ }^{77}$ Miller, "Subtle Embodiments: Imagining the Holy in Late Antiquity" in Boesel and Keller, eds., Apophatic Bodies: Negative Theology, Incarnation, and Relationality 57.

${ }^{78}$ Miller, "Subtle Embodiments: Imagining the Holy in Late Antiquity" in Boesel and Keller, eds., Apophatic Bodies: Negative Theology, Incarnation, and Relationality 57-8. 
${ }^{79}$ Jacques Fontaine, Naissance de la poésie dans l'occident chrétien: Esquisse d'une histoire de la poésie latine chrétienne du IIIe au VIe siècle (Paris: Études augustiniennes, 1981). Quoted and cited in Miller, Corporeal Imagination 90.

${ }^{80}$ Pseudo-Dionysius, "The Divine Names” 53, 74.

${ }^{81}$ Pseudo-Dionysius, “The Divine Names" 51.

${ }^{82}$ Pseudo-Dionysius, “The Divine Names” 51; Carabine 305-308.

${ }^{83}$ Pseudo-Dionysius, “The Divine Names” 80.

${ }^{84}$ Pseudo-Dionysius, "The Celestial Hierarchy" 149.

${ }^{85}$ Pseudo-Dionysius, “The Celestial Hierarchy” 147-8.

${ }^{86}$ Pseudo-Dionysius, "The Celestial Hierarchy” 150.

${ }^{87}$ Pseudo-Dionysius, "The Celestial Hierarchy” 148.

${ }^{88}$ Andrew Louth, ““Truly Visible Things Are Manifest Images of Invisible Things’:

Dionysios the Areopagite on Knowing the Invisible," Seeing the Invisible in Late Antiquity and the Early Middle Ages, ed. Giselle de Nie, Karl F. Morrison, and Marco Mostert (Turnhout: Brepols, 2005) 22.

${ }^{89}$ Pseudo-Dionysius, "The Celestial Hierarchy”: "In this way the wise men of God, exponents of hidden inspiration, separate the 'Holy of Holies' from defilement by anything in the realm of the imperfect or the profane. They therefore honor the dissimilar shape so that the divine things remain inaccessible to the profane and so that all those with a real wish to see the sacred imagery may not dwell on the types as true" (152).

${ }^{90}$ Otto 16-17.

${ }^{91}$ Pseudo-Dionysius, "The Mystical Theology” 136. 
${ }^{92}$ An entire volume is devoted to the resemblance of Derridean deconstruction to negative theology. Yet while it might be useful to think of putting the divine "under erasure," Derrida has insisted that the empty space of différance cannot be reconciled with any notion of divine presence, however deferred. See Derrida and Negative Theology, ed. Harold Coward and Toby Foshay (Albany: State University of New York Press, 1992).

${ }^{93}$ Pseudo-Dionysius, "The Mystical Theology” 135.

${ }^{94}$ Brown, "Rise and Function of the Holy Man" 87.

${ }^{95}$ See Martha A. Malamud, A Poetics of Transformation: Prudentius and Classical Mythology (Ithaca: Cornell University Press, 1989).

${ }^{96}$ Michelle Karnes, "Marvels and the Medieval Imagination," Speculum 90 (2015): 329. ${ }^{97}$ Karnes 329.

${ }^{98}$ Lois Parkinson Zamora and Wendy B. Faris, "Introduction: Daiquiri Birds and Flaubertian Parrot(ie)s," Magical Realism: Theory, History, Community (Durham: Duke University Press, 1995) 2.

${ }^{99}$ Prudentius, Liber Peristephanon in Prudentius, Loeb Classical Library, ed. Jeffrey Henderson, trans. H. J. Thomson (Cambridge: Harvard University Press, 1953) 343-5.

${ }^{100}$ Miller, The Corporeal Imagination 9-11.; See also Louth 17.; Jaś Elsner, Art and the Roman Viewer: the Transformation of Art from the Pagan World to Christianity (Cambridge: Cambridge University Press, 1995).

${ }^{101}$ John Chrysostom, The Cult of the Saints, ed. Wendy Mayer (Crestwood, NY: St Vladimir's Seminary Press, 2006) 222.

${ }^{102}$ Chrysostom 222. 
${ }^{103}$ Bettina Bildhauer and Robert Mills, "Introduction," The Monstrous Middle Ages, ed. Bettina Bildhauer and Robert Mills (Cardiff: University of Wales Press, 2003) 14-15.

${ }^{104}$ Jeffrey Jerome Cohen, Of Giants: Sex, Monsters, and the Middle Ages (Minneapolis: University of Minnesota Press, 1999) xiv.

${ }^{105}$ David Gordon White, Myths of the Dog-Man (Chicago: University of Chicago Press, 1991) 22-25.

106 White 22-25.

107 White 26.

${ }^{108}$ On the pagan origins of the Brigid legend, see Christina Harrington, Women in a Celtic Church, Ireland 450-1150 (Oxford: Oxford University Press, 2002) 63-68; See also Hugh De Blacam, The Saints of Ireland: The Life-Stories of SS. Brigid and Columcille (Milwaukee: The Bruce Publishing Company, 1942); Dianne Hall, Women and the Church in Medieval Ireland, c. 1140-1540 (Dublin: Four Courts Press, 2003); Elizabeth Rees, Celtic Saints in Their Landscape (Stroud, Gloucestershire: Sutton Publishing, 2001); Elizabeth Rees, Celtic Saints: Passionate Wanderers (London: Thames \& Hudson, 2000); I owe the observation about Brigid's eyeball to Ryen Rasmus.

${ }^{109}$ Cohen 136, 120.

${ }^{110}$ Robert Mills, “Jesus as Monster” from Bildhauer and Mills, eds., The Monstrous Middle Ages 39-41.

111 Mills 34.

112 Mills 48.

${ }^{113}$ Michael Camille, Image on the Edge: The Margins of Medieval Art (London: Reaktion Books, 2008) 17. 
${ }^{114}$ See Miller, "Subtle Embodiments: Imagining the Holy in Late Antiquity" in Boesel and Keller, eds., Apophatic Bodies: Negative Theology, Incarnation, and Relationality 45-58.

115 Jean-Luc Marion, The Essential Writings, Perspectives in Continental Philosophy, ed. Kevin Hart (New York: Fordham University Press, 2013) 120-121.

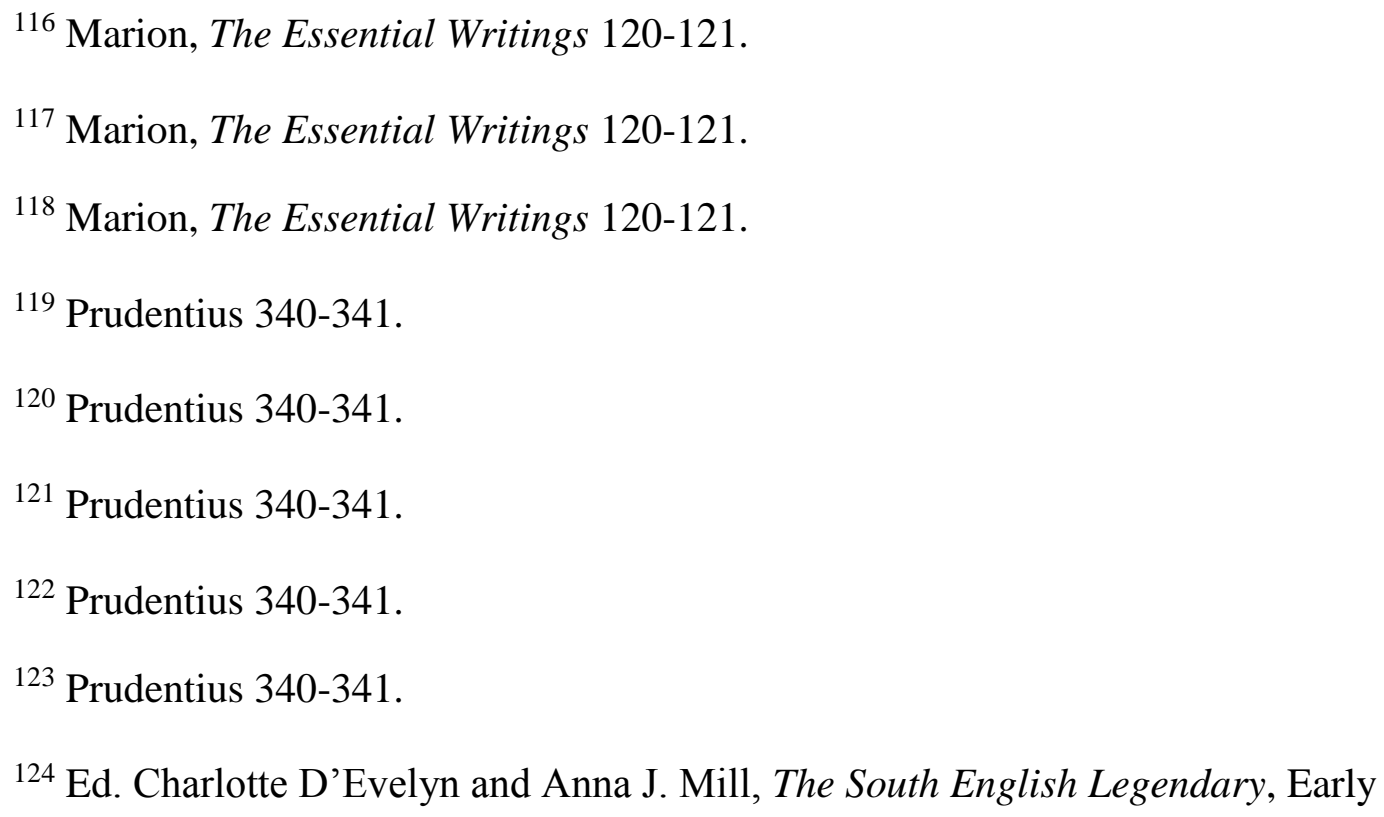


${ }^{134}$ Karl Rahner, Theological Investigations, trans. David Bourke, vol. 8 (New York: The Seabury Press, 1977) 24.

${ }^{135}$ Cardinal Suhard, quoted in Robert Ellsberg, All Saints: Daily Reflections on Saints, Prophets, and Witnesses of Our Time (New York: The Crossroad Publishing Company, 1999) 5.

${ }^{136}$ Ellsberg 5.

${ }^{137}$ Elizabeth Johnson, “May We Invoke the Saints?” Theology Today 44 (1987): 36, 43.

${ }^{138}$ Castelli 29.

${ }^{139}$ Prudentius 312-315.

${ }^{140}$ Marion, "The Invisibility of the Saint" in Elsner and Meltzer, eds., Saints: Faith Without Borders 356.

${ }^{141}$ Prudentius 312-315.

${ }^{142}$ Prudentius 312-315.

${ }^{143}$ Lawrence S. Cunningham, "Saints and Martyrs: Some Contemporary Considerations," Theological Studies 60 (1999): 536.

${ }^{144}$ David Matzko McCarthy, Sharing God's Good Company: A Theology of the Communion of Saints (Grand Rapids: Eerdmans Publishing Co., 2012) 38; see also Stanley Hauerwas, Sanctify Them in Truth: Holiness Exemplified (Nashville: Abingdon Press, 1998).

${ }^{145}$ Bishop Félix Dupanloup, "The Manner of Writing a Saint’s Life" in St. Chantal and the Foundation of the Visitation (New York: Benziger Brothers, 1895) 18.

${ }^{146}$ Cunningham 533. 


\section{CHAPTER ONE}

Sanctity and the Converted Gaze in the South English Legendary "Life of St Margaret"

Saintly bodies are neither real nor unreal; rather, they are effects of the hagiographical texts in which they appear. - Patricia Cox Miller ${ }^{1}$

The story of St. Margaret is, in many ways, typical. As in most virgin martyr legends, the protagonist must contend with hostile forces upon her conversion to Christianity. This confrontation takes the form of resistance to the sexual advances of a pagan suitor. Such resistance invariably elicits a violent response. The antagonist subjects her to torture, which functions as a deferred or coded rape. The South English Legendary's treatment of this archetypal plot excavates and explores a crucial theme of martyrdom: its reliance on the gaze. "Martyrdom” comes from the Greek $\mu \alpha \rho_{\rho} \tau \varsigma_{\varsigma}$ (martys), meaning witness. A martyr is constituted by the crowd that recognizes and affirms her as such. Even if she dies alone with her persecutor, a heavenly cloud of witnesses is imagined as watching (Heb. 12.1; 1 Cor. 4.9). As a concept, martyrdom requires an audience. The martyr is witnessed by others, bearing witness for others to an invisible reality that she herself witnesses. The witness of martyrdom is not only Janus-faced (the saint gazes simultaneously at heaven and the crowd), but binary (the crowd returns the saint's gaze). Though it also describes juridical and spiritual realities, the language of witness is one of vision.

The SEL "St. Margaret" explores the different modes of seeing available to those who would look on a saint. A saint's life may, by definition, depict embodied sanctity, but it must also depict characters who fail to recognize the holy. Immediately following Margaret's torments, the tyrant Olibrius stands back and regards the virgin's naked, brutalized form. The text imagines this regard as a difficult, almost impossible activity:

Alas also pe ssendfol dede hure deorne limes hi totere And pe Iustice for ssunnesse nolde loky perto 
Ac bihuld abac and hudde is eizen \& moni opere also...

Olibrius sat and bihuld hou hure limes ourne ablode

He nemizte for deol it iseo ${ }^{2}$

Once Margaret is most conformed to the abject, crucified Christ, her form repels the gaze. While the text does locate some agency in Olibrius, it also suggests that a force outside of the tyrant compels him to lower his eyes. The vita overdetermines Olibrius's unwillingness to look ("nolde loky") on his handiwork. He hides his eyes ("hudde is eizen") as if trying to escape someone else's gaze. It is not only the case that Olibrius will not look-he cannot look ("He nemizte... it iseo"). The sight itself forces the gaze back, and the text holds both in tension, describing a process of unseeing. Olibrius both beholds ("bihuld") Margaret's bloody form and "bihuld abac." One instance of "beholding" - the beholding that takes him aback or pushes him backwardexposes the blindness latent in the other instance. There exists a mode of beholding that undoes itself in the process of gazing. One must unsee a saint in order really to view her as a saint, for that which constitutes her sainthood ultimately remains invisible.

The text takes the readerly gaze through a process of negation, deconstructing its own hagiographical project. Yet it dismantles the gaze only to reintroduce it with a vengeance. By foregrounding the dark and inscrutable nature of holiness, the vita primes the gaze to witness the invisible reality surrounding its saintly protagonist. It assumes the structure of a diptych. Realism, defeat, fragmentation, and nonrecognition characterize the first half. Epiphany, spectacle, the miraculous, and conversion suffuse the second half. The episode hinging these panels together is one of the most famous in the hagiographical tradition: Margaret asks for a vision of her enemy and is swallowed by that same vision, which appears in the form of a dragon. At this midpoint, Margaret disappears from the reader's "view" entirely, consigned to the dragon's belly. When she returns, all the marvelous trappings of her sanctity are laid bare. 
The $S E L$ "Margaret" insists that the only way to gaze on the holy is to acknowledge its invisibility by enduring the ascesis of unseeing.

This tale enjoyed immense popularity throughout the Middle Ages, in large part because of its spectacular quality. Numerous versions survive. The $S E L$ version is exceptional for its vivid imagery and fast-paced dialogue. It avoids the long didactic and theological asides that characterize later hagiography. The $S E L$ was composed throughout the late thirteenth century and into the early fourteenth. It exists in several redactions. The lives of the $S E L$ have received less critical attention than those of many other less popular (in their day) hagiographical texts, in part due to this bibliographical diffusion. ${ }^{3}$ While liturgical and monastic contexts have been suggested, some believe the legenda were also read by individual laypeople. ${ }^{4}$ The inclusive use of "we" throughout many of the lives, especially those dealing with English national identity, might also suggest a lay audience. ${ }^{5}$ The collection tends to present saints in the thick of their ordeals, refraining from abstract or meditative interludes. More sensational than moralistic, the SEL puts sanctity on display in an especially descriptive, concrete way.

The SEL retelling of the Margaret legend maintains the martyr narrative's foundational concern with inglorious appearance versus miraculous reality. Late antique martyr narratives employed poetic, elaborately wrought word-pictures to spiritualize the brutal displays of violence staged in the arena. They worked hard to create a sense of triumph. For example, in his homily "On the Holy Martyrs," John Chrysostom (fourth-fifth c.) makes extensive use of ekphrasis, describing frescoes memorializing the martyrs before transitioning to highly figural descriptions of actual violence. ${ }^{6}$ This doubly compounded aestheticization reflects the ideology that martyrdom itself is performative—-beautiful and glorious, if rightly seen. ${ }^{7}$ Though vividly imagistic, the $S E L$ does not rely solely on word-pictures and rhetorical paradox in order to train 
the gaze. It makes use of these techniques, but it qualifies them in an interesting way, suggesting that they prove insufficient on their own. The SEL "Margaret" takes the gaze through a process of negation, iconoclastically undoing the images it has conjured. This iconoclasm exposes that which seems visually accessible as illusory or incomplete. In so doing, it prepares reader for the final reveal: an invisible, spiritual world suffusing the visible, material one.

\section{Margaret and the Gaze}

As an account of martyrdom, the $S E L$ "Margaret" shares late antique hagiography's preoccupation with spectacle. Gazing acts as the structuring principle and central activity of the vita and is inextricably bound up with spiritual conversion. The text examines the witness of sainthood refracted through its many onlookers. The life consistently links different modes of seeing with various possibilities of conversion. Sight words pepper the text: "sight" (2 times), “look” (2), “attend” (1), “see” (19), “eyes” (5), “behold” (4), "lo" (1), “search/seek” (3), and "find" (1). Where characters look and what they see relates directly to the movements of their "hearts" (8 times), which are often described as "drawing" (5) toward some perceived good. "Conversion" comes from the Latin conversio, meaning "with" (con) "turning" or "change" (versio, versionis). Its directional sense - to alter one's vector of motion as a result of an experienced change — metaphorizes interior changes like religious conversion. One Middle English word describing an inward shift toward something perceived as valuable by means of a motion-related metaphor is "wende" (15 times). In "Margaret," "wende" describes both interior states and physical motion. It often evokes a sense of "being drawn" by something, though it can also mean "to proceed" in a certain direction on one's own. The text also uses "turn" (4 times), which it prefers when characters undergo dramatic and explicit religious conversion. That these "looking" and "turning" words make up a significant portion of the poet's lexicon indicates his 
concern with the gaze's relationship to religious belief. The latter comes to change by means of the former, so the gaze itself must be converted before religious conversion can occur.

Within the SEL "Margaret," this conversion is initiated by the frustrating experience of unseeing. Occasionally, the spectacle of sainthood becomes opaque, irregardable, fragmentary, partial, or otherwise obstructed. ${ }^{8}$ Perhaps paradoxically, this ascesis of unseeing proves crucial to the text's ultimate project of disclosure. Set against the SEL's densely visual poetry, opaque moments startle the reader into looking more closely. They stand out against the backdrop of description, shadows cast over a tapestry. Throughout the first half of the narrative, "Margaret" explores sanctity in terms of its invisibility, representing these shadowed moments in various ways as the plot advances. More than a leitmotif, hiddenness, irregardability, and other forms of invisibility disrupt Margaret's visual availability - to the reader's mental gaze and to the gazes of other characters - consistently throughout the first half. This complicates the reader's attempt imaginatively to envision the events, and even the hagiographer confesses his inability to "see" certain episodes. A steady stream of squinting onlookers fills the tale, cuing the reader to scrutinize his or her own reactions to this opacity. In frustrating the gaze, "Margaret" draws attention to and critiques it, forcing readers to question what it means to see sainthood as mediated through hagiographical narrative.

Margaret's own conversion is represented as invisible to those around her. Her initial act of faith, arguably the most inscrutable moment of anyone's religious experience, sets the scene for her legend. The text describes this conversion in terms both spiritual and corporeal, locating it within the innermost sanctum of one's personhood: the heart. "For hure herte hure bar anon Cristene forto beo." "9 Beyond this interiority, the text provides no choreography, verbal confession, or external demonstrativeness - at least not yet. Though the reader possesses a kind 
of knowledge about Margaret's act of faith and her desire to serve the Christian God, this knowledge resists visualization and initially eludes those around her. Margaret's act of conversion remains invisible both by nature and by design. She consciously tries to hide it. The tale begins with the tension of dramatic irony. This secret faith is "displayed" for us within one of the most widely-circulated accounts of holiness in the Middle Ages. "Priueliche nizt and day" Margaret cries to God. ${ }^{10}$ Her appeals are constant but private, confined to silent solitude. Even her nurse, who loves her, "nas nozt al iwar to wan hure heorte drou."11 The text highlights this extensive secrecy by transitioning from the nurse's love to her ignorance with the conjunction "ac" ("but"). ${ }^{12}$ The first gazes that fall on the saint recognize her imperfectly or not at all, warning the reader that spectacles of sanctity require a certain mode of perception. The reader is privy to Margaret's sanctity even as other characters remain oblivious, yet the reader sees her faith precisely as a secret, hidden phenomenon, a semi-negated "sight" enabled only by the hagiographical medium. Her father comes to discern a change in her ("Hure fader sone it underzet"), but his discovery seems just that: an accidental uncovering of something his daughter has secreted away. ${ }^{13}$ Margaret begins her vita within the anti-spectacular tradition of catacomb sanctity, the hidden practice of an illegal religion. Even her father joins in this impulse to hide her:

Hure fader sone it underzet pat heo to Cristendom drou He made for hure deol inou ffram home he gan hure send... Viftene mile fram Antioche ${ }^{14}$

He sends her away even though she is "3ong inou" to make such an action seem unduly harsh. ${ }^{15}$ He banishes her to the countryside, where, theoretically, she will be separated from the social forces that might notice her faith and either encourage or punish it. 


\section{Idolatry and Iconoclasm}

Margaret's embrace of Christianity coincides with her rejection of the pagan gods, and this religious conversion is bound up with ideas about seeing. She considers the Greco-Roman gods to be demonic, a typical early Christian response to pagan deities. Many saints' lives identified pagan gods with demons, decrying the old shrines as haunts of evil spirits, in need of exorcism. Another clause follows this judgment of paganism. The text tells us that, "pe false godes heo held deuelen pat heo mizte aldai iseo."16 In this case, familiarity breeds contempt. Margaret can "see" these gods "all day." Constantly on display to the public eye, they lack the nimbus of mystery proper to the holy. Their self-evidential quality prompts suspicion in Margaret. They are too unironic, exactly what they seem. According to the Christian ideology at work in the text, the idol advances a triumphalist theory of the gaze and its capacities. Olibrius gives her another chance to "honure oure heie godes pat alle ping habbep iwrozt."17

Unbeknownst to the speaker, this pious expression contains a double entendre. He means to say that she should "honor our high gods, who have wrought/made all things." Yet because of the ambiguity of the pronoun "pat," the grammar also allows for the following sense: "honor our high gods, whom all things have wrought (who have been wrought by all things)." At the very least, the word "wrought" connotes the crafted, overly visible quality of the divinity thought to suffuse the idols. The concept of idolatry, however, is already laden with condemnation. It constitutes a judgment of one religion passed on another even while the devotional behaviors of pagan and Christian practitioners overlap in inescapable ways. The SEL plays with this proximity, participating in what Michael Camille has described as a "process of iconotropy." Iconotropy consists of "appropriating the alien image into one's own discourse." 18 Saints come 
to resemble idols while ostensibly critiquing them, and idols look less and less like statues and practices that gave offense a millennium prior.

The cultural trauma that attended martyrdom within the collective Christian consciousness was bound up with anxieties about idolatry. A public forum within which the Christian was ordered to offer incense to the gods afforded the dramatic setting for many martyr narratives. Yet where does image-worship appear in this text, and what does it look like? The pagan idols in "Margaret" never appear. They remain out of sight. The reader's aesthetic experience of Olibrius's gods conflicts with Margaret's pronouncements. The hagiographer describes neither statue nor temple. This restraint becomes noteworthy in light of thirteenthcentury Europe's artistic attitude toward idols. As Camille's study demonstrates, medieval Christians depicted idols obsessively, often in great detail. They conjured them in order to shatter them, to dramatize their fall again and again. The SEL "Margaret" destroys no statues because it describes none. Olibrius offers the only description of a "false god": Jesus Christ, an executed criminal "pat Giwes slowe on pe treo." ${ }^{19}$ Why have Christians enshrined a contingent event of history, idolizing the broken body of a failed prophet? Olibrius offers Margaret this challenge. In questioning Christ's divinity, Olibrius voices a concern internal to Christianity, one with which the church fathers contended and which continues today.

Within a medieval context, the character of Olibrius evokes other, heterodox Christians more vividly than it does the pagan tyrants of a millennium prior. The South English Legendary was produced in the midst of the church's struggles against heresy. It was assembled shortly after the Albigensian Crusade. ${ }^{20}$ The legendary circulated widely even as vernacular translations of scripture had become suspect. ${ }^{21}$ By the time of the $S E L$ 's compilation, hagiographical torture most directly alluded to the behavior of Christians. In 1252 Innocent IV licensed torture for the 
eradication of heresy. ${ }^{22}$ Larissa Tracy has described the "orthodoxy of torture," noting its relative acceptability within the $S E L$ 's socio-political context. Ironically, this means that the "form and frequency of torture in hagiography may have provided models of resistance and defiance for heterodox sects who saw themselves and their suffering at the hands of church authorities reflected in the stories of early Christian saints. ${ }^{" 23}$ Torture occurs very rarely in medieval English literature, the exception being hagiography. The excessive, surrealistic torture in works such as the SEL may have implicitly criticized torture as an imported, Continental practice. ${ }^{24}$ Olibrius's disdain for Christ's suffering humanity reflects Cathar concerns about the Incarnation as much as it does late antique pagans' objections. According to Cathar theology, Satan created the material realm, so all materiality bears the taint of sin. Such dualism rejected Christ's humanity, the idea of a Creator-God, and the church's sacramental economy. Despite this repudiation of material reality, the Cathars were often charged with idolatry. ${ }^{25}$ Christian writers (from polemicists to romance authors) tended to characterize all of their religious Others as idolatrous. Never mind that most of these Others (Jews, Muslims, Cathars) possessed anti-imagistic theologies. The accusation of idolatry placed non-Christians within a meta-narrative of stark religious difference. The martyrs, Christianity's first cultic heroes, imbue Christian sanctity with an anti-idolatrous stamp by refusing to offer incense to the gods.

As a category of difference, idolatry was grayer than it seemed, partly because the discourse against it emerged out of concerns internal to "orthodox" Christianity. Various aspects of cultic devotion — from relic veneration to iconography—were decried as Christianized forms of idolatry. ${ }^{26}$ These anxieties about cultic devotion never vanished, though they gained new, subtler expression. By the thirteenth century the Christian West's ambivalence toward holy imagery had become much less pronounced, its material culture reflecting mass acceptance. Yet 
the production of holy images necessitated an explicit discourse exploring the possibility of conflating representation and represented. Artistic depictions of fallen idols intersected with those of triumphant saints, with the latter cast as acceptable replacements. For example, whereas pagan poetry was filled with stories of statues springing to life, Gothic medieval hagiography contained many similar statue miracles, often featuring the Virgin, but sometimes others like St. Nicholas. ${ }^{27}$ This iconotropic technique risked collapsing the two. The typical layperson was unlikely to understand (or even encounter) the subtle theology defining the differences in kind and degree of worship. Only the Trinity was to be accorded latria. The saints received dulia, veneration proper to creatures, however holy. As immaculate Theotokos, the Virgin Mary received hyperdulia, a vague and singular category. ${ }^{28}$ The Middle English word "worship" expressed all three modes. Sometimes things got confusing.

The vita's first sentence might give one pause: "Seinte Margarete was holy maide and god." 29 Through a homographic trick, the first sentence sets forth an ambiguity inherent in Christian sainthood. Margaret is "holy" and "good"; Margaret is "holy" and "God." This latter, idolatrous sentiment has both phonetic and theological force. As the Eastern theology of sainthood makes clear, a saint is a person swept up into the divine life. The process of attaining holiness is one of "divinization" or "deification" (theosis). The parallel, but less striking, Western equivalent is "sanctification." While Christian theology distinguishes between apotheosis (becoming a god) and theosis (union with God), the distinction remains subtle even on the theological level (to say nothing of the aesthetic). Where does the saint end and God begin? A saint, Margaret certainly shares in the divine life. How does this differ from identifying her as a deity? The theological ambiguity lingers. The entire vita will respond to this ambiguity. The first half does so by means of an iconoclastic, negating aesthetic. 
It remains tantalizingly unclear which mode of worship Margaret engages in first. She is converted by the cult of the martyrs. Olibrius wants Margaret to "wende to is false godes to do sacrefise," but Margaret shows no interest in the pantheon she has inherited. ${ }^{30}$ Another spread of sacred heroes catches her attention. Margaret first "sees" the Christian God through the linguistically-mediated witness of the saints, through hagiographical speech or writing. (It remains unclear how, exactly, Margaret hears of the saints who inspire her.) Hearing God's Word, however mediated, is a non-visual mode of seeing — perhaps seeing with the "eyes of the heart." In the lines immediately following Margaret's contempt for the overly-manifest gods of paganism, we learn about the individuals who have redirected her gaze: "Of seinte Steuene heo hurde telle and of sein Lauerence also/ Hou in stronge martyrdom hi were to depe ido/ And of oper martirs ek" (emphases added). ${ }^{31}$ These stories make Margaret long to suffer similar torments and to perish in the name of Christ. "Heo wilnede euer to beo ido for oure Louerdes loue to depe" ("She continuously desired to be done to death for our Lord's love"). ${ }^{32}$ This intense death drive constitutes her faith, reflecting the form of Christ. Not merely inspired by the saints or convinced by the extremity of their testimony, Margaret desires to do exactly as they did. The spectacles of martyrdom that so inspire Margaret are visible only in her mind's eye, which differentiates the hagiographical project from pictorial, dramatic, and sculptural representation. Here, the hagiographer advocates for his own medium - a transformative force without the dangers of idolatry, or so it seems.

Her transformation into martys happens the instant she recognizes Steven and Lawrence as saints, and that recognition is ostensibly recognition of the Christian God. Yet what does it mean that Margaret's conversion is doubly mediated? First, by Christian saints; second, by the words that recount their trials. The reader, a consumer of hagiography, enjoys the privilege of 
watching a saint consume hagiography. Margaret serves as the perfect reader, held up as an aspirational prototype. She exemplifies perfect witness even before she is martyred. She witnesses God's martyrs (themselves witnesses) and immediately enters into their gaze, able to see them as saints by seeing Christ in them. Her desire to imitate them literally might seem pathological, but it also emphasizes her perfect replication of the vitae that she has heard. Seeing the witnesses perfectly, she cannot but witness as they do. ${ }^{33}$

Despite the super-exemplarity of a martyr's being converted by other martyrs, this template of sanctity exercised both orthodox and heterodox Christians. That the SEL compiler chooses to mention St. Lawrence is striking, since Lawrence inspired thirteenth-century Christians to brave martyrdom many centuries after Margaret. The SEL life of Lawrence "reads very much like the trial transcript of an accused heretic," as do other lives in the collection. ${ }^{34}$ Medieval readers would have recognized the instruments of torture as those used by papal inquisitors, who were, like the Roman authorities, often accused of overstepping the already questionable boundaries drawn for them. ${ }^{35}$ Catholic Christians were dismayed when Cathars and Waldensians claimed kinship with the apostles whose cults they rejected, comparing their persecutors to Roman tyrants. ${ }^{36}$ Despite Catharism's doctrinal opposition to cultic devotion, many Cathars recognized that, as victims of violent, religio-political suppression, their situation resembled that of the early martyrs. Centuries later, John Foxe's Actes and Monuments of the Protestant martyrs also drew an analogy between religious dissenters and the earliest saints. Catholic Christians, then, were not in control of "their" saints, not even as mediated through hagiographical texts. This should not be surprising. Many scholars have pointed to the unruly nature of cultic devotion. Aviad Kleinberg describes the grammar of sainthood in this way: "Saints legitimize vocabularies but they subvert syntactical rules. Even when they justify the 
existing order, they serve as demonstrations that contradictions are possible." ${ }^{37}$ Exceptions to the rule, saints often broke the rules, so little wonder if popular devotion to them eschewed regulation. Spectacles of violence-even linguistic spectacles of violence-overran attempts to circumscribe and control their meaning. Just as Margaret sees heroism in political execution, so do thirteenth-century "heretics" see licensed rebellion in a canonical saint.

This puts the hagiographer in a bind. On the one hand, he wants to emphasize the extent of Margaret's sufferings, thereby illustrating her extreme endurance. On the other hand, his religio-political context charged depictions of torture in potentially dangerous ways. Catholic Christians associated religious difference with idolatry. They did so even as they worried over the increasingly idolatrous appearance of their own devotional practices. Margaret's conversion indicates the immediate and powerful transformations that saints' lives could effect. Because of this, hagiography could theoretically inspire idolatrous impulses too, even if the images in question were mental constructs, conjured by written or spoken words. In some ways, a heterodox impulse was an idolatrous impulse: the rendering of improper worship. The $S E L$ "Margaret" recognizes this and engages in an implicit iconoclasm subtler than the explicit iconoclastic disdain for pagan idols. This iconoclasm never goes all the way, though. In that respect, it differs from that of the eighth- and ninth-century iconoclasts or sixteenth-century reformers. This hagiographical iconoclasm wants to preserve saintly worship (as dulia) while condemning saintly worship (as latria). Aesthetically, this self-censorship proves a delicate operation, with a lot of room for ambivalence and heterodoxy.

This impulse to unsee spectacles of the holy can be found in the parallel discourse of apophatic (or negative) theology. Techniques and ideas imported from apophatic theology do iconoclastic work while preserving the orthodoxy of cultic devotion. Without abolishing images 
(either actual or discursive), apophatic theology could critique material culture, reminding devotees of God's ultimate invisibility and transcendence. As far as I can tell, Patricia Cox Miller is the first scholar to argue that the paradoxical rhetoric of late antique hagiography endows the saint with an "apophatic body," one that escapes reification. ${ }^{38}$ It is not, however, immediately apparent that hagiography would find an ally in apophatic discourse. PseudoDionysius became known for statements like, "I pray we might come to this darkness so far above the light!" 39 He would seem to have "provided grist to the iconoclast mill, [but] there is precious little evidence that the iconoclasts made any use of this. ${ }^{\circ 40}$ Iconoclasts did not recognize Pseudo-Dionysius as an ally_despite his seemingly anti-imagistic claims. No doubt this is because his apophatic Mystical Theology made sense only when read against his cataphatic treatises (Celestial Hierarchy, Ecclesial Hierarchy, Divine Names). Apophatic negation was not destruction, but a kind of working, meditative erasure enabling the devotee to imagine past material and linguistic symbols while retaining their truth value. In hagiography, this takes the form of negating or undoing the saint's aesthetic availability, reminding readers that holiness stands at a remove from mundane reality even as it inhabits it. By drawing a rhetorical veil over its holy subject matter, a saint's life could remind devotees that holiness did not reduce to any material thing. It could not be reified, therefore holy persons should not be adored for their own sake. This apophasis functioned as a quasi-iconoclastic defense against idolatrous veneration. Before making the apophatic move, the text reconstructs the false seeing that might seduce the gaze - negative looking in the moral, not the apophatic, sense. Throughout much of the first half of the SEL "Margaret," the protagonist's persecutors perform acts of negation on her body. These negating moments differ from the iconoclastic impulses in the text. In fact, they expose various parts of her to the persecuting eye. This bares her before the hagiographical and readerly eyes as 
well, implicating the devotional gaze by forcing it to share in that of the persecutor. (This could have drawn attention to the Catholic church's role as persecuting agent.) The reader participates in a mode of gazing that the hagiographer will ultimately criticize.

To "persecute" means to follow or seek (sequor, sequi) something through (per) to the end. This "going out" to find hidden Christians is described as a kind of "wending," a sinister version of the "wending" of Margaret's heart toward Christ. ${ }^{41}$ The persecuting gaze fantasizes that it might overtake its object-indeed that there is an object to overtake, rather than an irreducibly mysterious Other. The pagan official Olibrius, a servant of Diocletian, embodies this gaze. A literal persecutor of Christians, he attempts to see Margaret comprehensively through every means available to him. This rapacious gaze seeks information forcibly and totally, preferring penetrative violence to reverent patience. Both the emperor and his servants are described as "Luther" ("cruel") because they "destrude al Cristene men and wel wide sozte" (emphases added). ${ }^{42}$ In order to enact their violent agenda, they must uncover Christians who have gone into hiding, working against the privacy that Margaret seeks. Diocletian's servants search "wel wide," "alonde wide," "in everich side," and "into Asie."43 These persecutors are sent to "finde" and "seche" Christians, demanding that they honor the Roman gods or suffer execution. $^{44}$ Their gaze does not passively fall on Christians, it actively seeks them out, registering political treachery as opposed to sanctity. ${ }^{45}$

According to the logic of a saint's life, the persecutors do not see the saints at all. The negating violence they enact reflects their fragmentary vision. They do, however, recognize the saintly individual as exceptional. This gaze, though utterly wrongheaded within a hagiographical text, contains the germ of possibility for a purified gaze: pure potentiality in the negative. Diocletian's soldiers seek the hidden saint, but in exactly the wrong way. They enact the wrong 
kind of gaze, providing readers with an antichristian example of what they themselves should be doing. The hagiographer weaves pagan and Christian looking together, setting up a dichotomy that will characterize the entire text. The friction between these two gazes opens up the space for conversion - a religious conversion that begins with frustration of the gaze. By adjusting the way one looks, one might come to recognize holiness. The experience of opacity or obstructed visibility acts as a prelude to this conversion. John Chrysostom describes these two gazes in a homily about martyrdom: "For the tyrant and the martyr weren't looking at the same things. Both had the same eyes, but of the flesh. But the eyes of faith were no longer the same. Instead the former looked at the present life, the latter viewed the future toward which he was about to fly." $" 46$ The tyrant sees only what is before him; the saint sees heaven. The tyrant looks with his eyes; the saint, with her soul.

Form, Beauty, and Torture

Little wonder that these tyrannical "eyes of flesh" would possess an intrinsically pornographic quality. The same desire to expose divinity by crafting idols manifests in Olibrius's desire to uncover, touch, and penetrate the saint's flesh. ${ }^{47}$ Olibrius would have the story become literally pornographic (i.e., "writings about prostitutes"). As soon as Margaret denies him definitively, he refers to her as "pis hore." 48 From the beginning, he has presumed her sexual availability. Out on his mission to "seche Cristene men and quelle" them, Olibrius spies Margaret shepherding her flock. ${ }^{49}$ The official's visual intake of the saint contrasts sharply with her auditory intake of Sts. Lawrence and Stephen. The text overdetermines her exposure to the eye. He "bihuld" her and "rizt in fole loue is herte to hure drou." 50 The language with which the text describes Olibrius's “foul love” resembles Margaret's religious conversion. Her own "heorte drou" to a lover as well — to Christ, to whom she commends her "bodi in clannesse."51 Olibrius's 
desire for Margaret mirrors and inverts her desire for God, signaling to readers that whatever this gaze beholds it will profane. Indeed, the forceful, tactile sense of "be-hold" emerges right after Olibrius determines to "is wille habbe in folie" with Margaret. ${ }^{52}$ Not content to contemplate, the persecuting gaze must consume. "He bihuld pis maide faste," demanding she tell him if she comes from aristocratic blood. ${ }^{53}$ This second instance of "behold" is even more ambiguous. Does it mean that the justice's gaze has intensified, fired by lust? Or has he, at this point, made his way across the field and seized her? The adverb "fast" suggests the latter meaning: to "hold someone fast" means to "fasten" that person in your grip. For Olibrius, looking bleeds into touching.

One source of tension between Margaret and Olibrius seems to lie in their radically opposed conceptions of the beautiful. By extension, this affects their attitudes toward desire. Olibrius characterizes Margaret's faith as an aesthetic offense. When Margaret reveals herself to be a Christian, Olibrius appeals not to law, force, tradition, piety, or even questions of belief — at least not during this first, instinctive reaction. Rather, he transitions from an aesthetic evaluation of the saint's superficial beauty to an evaluation of Christianity on the same terms. The assumption that a phenomenon's ready visuality reflects its essence lies beneath such a valuation. He claims that, unlike her lovely name (which means "pearl"), the name of Christian "bicomp pe rizt no3t as pou mizt iseo." 54 This characterization of Christianity as "unbecoming" or "not comely" seems odd because it describes a metaphysical reality in the register of physical beauty. The logic strikes a discordant note. Olibrius offers his proof of Christianity's aesthetic inferiority as self-evident: "as you might see." It seems to be the case with profane gazing that the cognitive sense of "see" coincides with its literal, visual sense. This echoes the phrase with which the hagiographer first expresses Margaret's suspicion of the pagan gods: "pat heo mizte aldai iseo." 55 The self-evidence arousing the saint's suspicion functions as an unproblematic premise for the 
tyrant. The vast spiritual gulf between them reduces to a difference in looking. The gaze acts as a cipher for the spiritual state of a character. What, though, is Christianity's aesthetic crime?

Christianity offended ancient understandings of the beautiful. That the new religion centered on an executed criminal proved as distasteful formally as metaphysically. Olibrius sets Margaret's eroticized body against Christ's abject body, explicitly stating that these bodies, one beautiful and one deformed, do not belong together:

pat pou honure pane false god pat Giwes slowe on pe treo Such noble maide as pou ert God ssulde pat it so nebeo For such hendi body as pou berst bicome bet in boure In min armes ligge iclupt panne a false god honure ${ }^{56}$

Referring specifically to the mode of death ("slew on a tree") reminds readers that crucifixion was a particularly ignoble mode of execution, reserved for traitors who threatened the empire's stability. It displayed the body in order to ridicule it, as opposed to beheading, a swift and “nobler" mode of execution. In Christianity's earliest days, it was by no means certain that the cross would become the religion's most emblematic symbol. Yet by the twelfth century, it loomed foremost in the Christian imagination — so much so that preferring not to look on images of the Crucifixion was identified with heresy. Devotion to the crucified Christ affected ascetic praxis. Within certain monastic communities, self-flagellation became a popular means of participating in the Passion event. For many theologians, especially Peter Damian (eleventh c.), “to refuse in one's mistaken — indeed, diabolical—modesty to appear naked before one's fellows and to suffer Christ's ignominy and pain was to refuse to look on Christ himself." 57 This transvaluation of abject bodies from ugly to beautiful required a great deal of poetic infrastructure and theological bolstering. In viewing the crucified Christ as a figure of humiliation, Olibrius articulates the reaction voiced by the anti-Christian polemicist Celsus in the third century. Olibrius demythologizes the Crucifixion story, casually recounting it as a 
contingent event of history — a partisan, uniquely Jewish event. The lack of written mentions of Jesus dating back to his own life and immediately after testifies to the initial pagan opinion that the carpenter from Galilee was of little consequence. ${ }^{58}$ While the tyrant finds Christ's naked body distasteful, he would like to see Margaret's. He makes the less intuitive leap from Christianity's apparently failed god to Margaret's "hendi body," which would better please the eye as a sexually available form on a bed than prostrate in Christian worship. Why does Olibrius object to her faith? Because of its unseemly cruciform aesthetic (especially offensive without the restorative light of the Resurrection), yes, but also because it renders her inaccessible to him. ${ }^{59}$ Ultimately, these objections amount to the same thing, an impatience for that which holds back, resisting a certain kind of gaze. The profane gaze is no gaze at all but, rather, a mouth that consumes, destroying the thing for which it hungered. Margaret responds to Olibrius's logic with an explanation of Christian salvation ("we were poru is dep out of pine ibrozt"), but he will have to experience the opacity of the Cross for himself. ${ }^{60}$ Rapacious looking runs itself up against a wall, encountering that which it cannot comprehend. The ascesis of invisibility trains such a gaze not to demand exposure and immediate access. That or it frustrates it into solipsistic madness: a gaze gazing at itself gazing.

The profane gaze demands exposure not for its sake alone, but out of a desire to penetrate and possess. The more or less explicit desire to penetrate Margaret sexually, once frustrated, reveals its underlying rapacity. This penetrative looking transfers its energies from the sexual to the overtly violent. Metaphysical questions frame the concerns worked out on Margaret's flesh: where is divinity located, what does it look like, how does one render it right worship? Despite the religious nature of Margaret's crime, Olibrius trains his energies on her body, not her soul. His desire to access what should remain private or mysterious assumes a fierce literalism. After 
his intimidation tactics fail, he asks her to "reu on pi faire bodi" so that it will not be "forpere" by punishment. ${ }^{61}$ The word "forpere" continues the aesthetic line of persuasion, contending that torture would "mar" her "fair body." His prioritization of her physical beauty reveals a monstrous misperception soon to have actual consequences. Radically privileging his own eyes and what they desire to "behold," Olibrius disregards the life animating that "hendi body." As is characteristic of virgin martyrdoms, the text transitions from the threat of sexual violence to the realization of physical violence, linking the two explicitly. Ironically, Olibrius calls Margaret "hore" once she has shown herself willing to suffer martyrdom in order to preserve her chastity, identified with her commitment to Christ. ${ }^{62}$ He fancifully transfers his own lust onto the saint's body, imagining that which holds itself back as promiscuous. Yet Margaret has not held herself back, but has given herself, body and soul, to Christ. This comprehensive givenness to the invisible arouses the official's ire.

By fetishizing her exterior beauty, Olibrius sets this beauty up to be either negated or apotheosized. He has created an idol by loving Margaret's surface appearance for its own sake. The worshipful language of love poetry is generically adjacent to tyrannical speech within virgin martyr narratives. ${ }^{63}$ This misplaced devotion proves analogous to the error that iconoclasts feared devotees might make with regard to religious artwork: they might offer their worship to the material object, rather than the person to whom it refers. While a living individual's preoccupation with another's beauty might be seen as a kind of idolatry, Margaret's beauty is a rhetorical construct. This means that Olibrius's idolatry occurs in the reader's imagination, and these mental images are evoked by the hagiographer's text. Tyrant, reader, and hagiographer are all complicit in this idolization of Margaret's external beauty. The story of Pygmalion provides a direct example from the pagan past. Most famously recounted by Ovid in the Metamorphoses, it 
depicts a sculptor who falls in love with the external beauty of a statue he has carved. It gives the lie to iconoclastic arguments, though, since Aphrodite rewards his love by imbuing the statue with life. Stories such as that of Pygmalion hovered in the background of early Christian suspicion of images, especially rounded sculptures. ${ }^{64}$ It was a real concern that similar idolizing impulses might find a home within cultic devotion. The superficial appearing of a saintwhether in body or in art—must be transcended. At the height of the text's celebration of Margaret's beauty, it engages in iconoclastic violence in order to undo that beauty.

In keeping with the virgin martyr subgenre, Margaret emphatically rejects all attempts to sexualize her. Her Christian assent and erotic "no" (at least to a pagan suitor) collapse into one movement of the will. The virgin's unalterable intentionality signals an interior realm to which the tyrant has no access. He abruptly shifts registers, pivoting on the word "whore" from persuasion to force. Betraying the violence with which he has viewed Margaret all along, he commands that the torturers "towdrawep hure so uel \& fleiss pat me hure gottes iseo" (emphases added). ${ }^{65}$ He has her "strupte naked" and bound "faste." 66 "Fast" here echoes the moment of initial meeting, wherein Olibrius "beheld her fast." The "holding down" has become undeniably violent now. What was latent in his gaze is now realized in his actions. The form he must have undressed with his eyes, as it were, is now stripped by armed guards. The body that he desired naked in the private space of a bower is now publically exposed to a multiplicity of gazes. Olibrius sentences Margaret to total appearing, requiring that the innermost parts of her be revealed to his eye. Where once he wished to see her within the circle of his arms, he now wishes to "see her guts." This grisly exteriorization of the interior only approximates the power he desires: to control her will, "converting” her soul away from Christ. ${ }^{67}$ Margaret realizes as much, acknowledging that "Pou hast poer of mi body forto do pi wille/ Ac me Louerd wit mi soule wel 
pou nessel hure no3t aspille." ${ }^{68}$ Much to his frustration, Olibrius can only exercise his will over her body. Her soul remains inviolate and protected by God. Olibrius resists this hiddenness in visual terms, uncovering everything he can. Perhaps the most aesthetically paradoxical moment in the vita follows the justice's articulation of his desire to "see her guts." The text participates, at least aesthetically, in Olibrius's desire, describing the torture in vivid, poetic terms. This description of torture seems a delectation of violence, meditating on body parts as they undergo hurt.

What follows is a poetic shattering or negating of the saint's physical form. The scene begins with Olibrius ordering her stripped naked and beaten. Vivid as any sonnet, the passage describing Margaret's torture presents readers with an example of what one might call hagioblazonry. Such descriptions of bodily torment appear not only in accounts of martyrdom, but in the lives of those saints (most saints) who practiced various forms of asceticism. These moments recur enough to merit the status of generic convention and prove comparable to love poem blazonry in several ways. They literalize the fragmenting violence implicit in categorized paeans to the female body. ${ }^{69}$ These poetic catalogues take deconstruction all the way to destruction in martyr narratives. While the male body is occasionally eroticized, female dismemberment is nearly always given in sexual tones, often with a male suitor looking on as in the SEL account of St. Margaret. ${ }^{70}$ With its combination of pity and poetry, the torture of St. Margaret is especially visceral. Olibrius demands to see her guts, and this word-painting follows, affording readers and tyrant alike a visual of the brutalized body:

pe maide hy strupte naked sone $\&$ bond hure faste inou Al fram pe eorpe hi honge hure up \& leide hure on to gronde Wip scorgen and kene pricken \& made hure many a wonde $\mathrm{Al}$ hi todrowe hure tender vleiss pat reupe it is to telle Bi stremes pat blod orn adoun so water dop of welle For hure limes tender were pe scorgen smart and kene 
Bi peces pat fleiss fel adoun pe bones were ysene Alas hure swete tender body so villiche todrawe so Alas hou mizte enyman such dede for rupe do Wip oules hi todrowe hure wombe pe gottes isene were ${ }^{71}$

In preparation for the scene, the justices strip the saint bare and hang her from a tree. Like Christ on the Cross, she is maximally exposed, stretched out and unclad. The text then delivers a pictorially and emotionally vivid account of the pain inflicted. The modes of damage abound, presented as a catalogue of wounds. The torturers penetrate her skin through scourging, stabbing, and tearing, causing "many a wound." The text describes the "pieces of flesh" that "fall down" as well as "streams of blood" and a "torn-open womb." Even as it presents these details, the text presents them as seen. What readers imaginatively envision, onlookers are imagined to witness. The seeing verb ("y/isene") here describes portions of the anatomy characterized by their hiddenness, structures that should never be seen: "the bones" and "the guts." onlookers can see these private structures indicates the severity of the beating. The hagiographer concludes his blazon with a declarative statement of Olibrius's initial command. "The guts were seen." Both torture and poetry conclude once this exteriorization of Margaret's innards has been achieved.

Olibrius is not the only one in love with Margaret's beauty. In an odd moment—perhaps symptomatic of the virgin martyr subgenre- the hagiographical gaze shares in the tyrant's. ${ }^{73}$ Just as Pygmalion fell in love with the work of his own hands, so does the hagiographer admire the "tender little virgin" he has constructed. Once Margaret has denied Olibrius's offer of marriage, he calls her "whore." The hagiographer succumbs to a similar temptation to sexualize his protagonist, lingering over the body his rhetoric disfigures. He admires her form even as he constructs a passion scene that fragments that form, undoing her external beauty. Truly a variety of blazon, this passage aestheticizes the torments, and it does so to produce a titillated sort of 
pity. As in love poetry, the hagiographer isolates a piece of female anatomy and refers readers to some other, comparably beautiful thing. It is worth noting that the SEL "Margaret" keeps figuration to a minimum, making this interlude all the more striking. He describes Margaret's bleeding in figurative, romanticized terms, streaming "like water from a well." In his fascination with the martyr's blood, the hagiographer resembles Olibrius, who tries to determine whether or not her veins flow with "gentil blod."74 The variation in verb usage as well as the compounded modifiers ("kene," "smart," "villiche," "faste") make this passage self-consciously poetic (the tale's verse form notwithstanding) as do the narrator's pathetic interjections. Emotive outbursts ("tender flesh," "ruth it is to tell," "limbs tender," "sweet tender body," "how might any man for pity...") seem to set the hagiographer's devotion against the tyrant's rapacity, justifying his (and our) voyeurism by means of virtual compassion. If Margaret suffers, at least the reader suffers along with her. Yet mediated by the convention of hagio-blazonry, we experience the saint's agonies in the mode of poetic passion, which gives itself as aesthetic pleasure. The blazon is a convention with an erotic genealogy, rendering that pleasure - in the context of martyrdomsomewhat culpable. The hagiographer "suffers" like a lover scorned and left alone with his poetry. His heroine is imagined to suffer in her flesh. This move may be an ethically dubious aspect of the politics of representation inherent in the virgin martyr subgenre. The hagiographer may also, however, be redirecting this conventional topos toward a larger critique of the gaze. The poem guides readers into a gaze at odds with the saint's, setting us up to experience correction. Margaret herself proves the truest iconoclast, at least in this first half. She flintily rejects the pity her situation generates in both onlookers and narrator. In response to the crowd's plea that she pity her body, she replies, "3e wikkede conseillers gop fram me anon," echoing Jesus's words to Peter, "Get behind me, Satan" (Matt. 16.23). ${ }^{75}$ The sympathy that ostensibly 
differentiates narrator from tyrant produces an uncanny alliance. For Olibrius, too, calls Margaret's body "hendi" and asks her to "rue on her fair body." admiration of Margaret's young, nubile form, the hagiographer draws readers into a subtler mode of the tyrant's this-worldly gaze. The very project of poetically rendering a scene of torture, providing a linguistic account to be envisioned, necessarily compromises both hagiographer and reader. Whether we will or no, we are forced to share in Olibrius's pornographic gaze, simply by virtue of our reading the tale. The legend itself acknowledges this complicity with a grotesque literalism. The tormenters scrape Margaret's body with "awls," a tool used to produce parchment. The saint's body becomes the page on which her life is inscribed. Where do we stand ethically and spiritually once we have imagined those "tender" limbs, stung and torn by a crowd of leering men? Yet the more Olibrius uncovers the saint, the more remains unapparent. Olibrius comes to sense his blind spot, infuriated that so much remains out of the purview of his gaze. At this moment of maximum exposure, Margaret becomes most resistant to the gaze. The only way to convert such a gaze is to disrupt it altogether. Immediately after Margaret's guts are exposed, the gaze turns in on itself, and Margaret becomes irregardable.

\section{The Martyr's Irregardability: Negating the Gaze}

The hyper-poetic visuality of Margaret's passion feeds the gaze so richly only to suggest that such seeing constitutes a mode of blindness. Once the torture has concluded, the crowd stands back to take her in. This moment of beholding lasts twenty-five lines, a contemplative pause in-between her ordeal and her second imprisonment. Yet the crowd finds its collective gaze repulsed. The people lower their eyes, unable to look on Margaret once she is most conformed to Christ. Here, a mysterious irregardability comes over Margaret. As mentioned earlier, Marion offers irregardability as one category of the saturated phenomenon: "Determining 
the saturated phenomenon as irregardable amounts to imagining the possibility that it imposes itself on sight with such an excess of intuition [in-flowing phenomenality] that it can no longer be reduced to the conditions of experience (objecthood), therefore to the I that sets them." 77 This is one way of understanding the spectacle of martyrdom. The phenomenon before Olibrius exceeds his ability to perceive it; the net result of this is an experienced darkening of the senses. The mob that has exposed so much to the eye finds itself incapable of even literal witness. They cannot train their eyes on her.

These twenty-five lines contain a disproportionate number of the tale's sight words, yet almost all of those words are grammatically negative. Olibrius "nolde loky perto/ Ac bihuld abac and hudde is eizen \& moni opere also." ${ }^{.78} \mathrm{He}$ cannot bring himself to look upon her. The hagiographer restates this fact in several ways, clarifying the point that this irregardability has force and reality — is literal, and not rhetorical shorthand. Several sight words are repeated and undone in this moment, revealing the blindness that has always characterized Olibrius's gaze. Where once the tyrant "beheld" Margaret in lust and perhaps even "be-held" her in force, now he "beholds back." He "sat and bihuld" her bloody limbs, abashed. ${ }^{79}$ Margaret now repels his persecuting gaze, pushing it back. If she could not to remain "ihud" from the official's eyes, the official now hides those same eyes from the saint. ${ }^{80}$ Emphasizing the retreating gaze, the hagiographer literally cloaks Olibrius's eyes: "He nemizte for deol it iseo ne monie pat pere stode/ Wip is mantel for reupe and deol he helede bope is eize/ So dude monie anoper ek pat hi pe del neseie." 81 These lines combine a sense of inability ("nemight") with unwillingness. He puts his cloak over "both" eyes, hiding ("helede") them. Where once he desired to see all the way inside of her, now he cannot bear to look on her, for all her bleeding: "He nemizte hire for deol iseo so deoluoliche blede." ${ }^{\prime 22}$ The overdetermined hiddenness of eyes that once rousted 
hidden things from their sanctuaries manifests the triumph of saintly phenomenality, and its necessary overwhelming of the gaze. That is, the wrong sort of regard goes dim in the holy's presence, exposing the fact that it was nothing but a mode of blindness all along.

The passage makes an explicit link between conversion of the gaze and conversion of the soul. Toward the end of this passage, the narrator uses a sight word in a more cognitive manner, asserting that Olibrius "sees" that he cannot convert Margaret to his will. ${ }^{83}$ The counter-spectacle of saintly destruction, while it turns the gaze in on itself, forces Olibrius to articulate his blindness further. He betrays his distorted sense of value by asking her to pity her beauty, and by insisting she end these torments by converting (or reverting) back to her pagan faith. He asks that "pou wolle pi po3t wende" (emphasis added) ${ }^{84}$ Shortly after, he makes the same request in terms that strikingly echo the hagiographical sensibility: "turn zute pi pozt ich rede/ And among alle wymmen pat ich knowe best lif pou sselt lede." ${ }^{, 5}$ Both exhortations employ conversion words ("wende," "turn"), expressing the tyrant's desire to access the inner sanctum of Margaret's personhood. He wills that she will to convert. ${ }^{86}$ Yet this second statement possesses an added valence, casting Olibrius as both a consumer of hagiography and as the worst sort of reader. As Margaret absorbs the lives of Sts. Lawrence and Stephen, so does Olibrius have the opportunity to learn from Margaret's exemplarity.

The hagiographer subtly offers Olibrius as a counter-example to Margaret's perfect reception of hagiographical lore. Olibrius adds "ich rede" to his command. Context suggests that the verb's stronger sense is "advise," but it can also mean to "read." Olibrius does read Margaret, but her sanctified existence does not translate into an idiom he can understand. She remains illegible to him. Should she convert, he insists that she would have the "best life" that a woman might lead ${ }^{87}$ Applied to Margaret, the word "life" cannot but evoke the literary genre of "saint's 
life" as much as embodied existence. Olibrius imagines a counter-narrative to the one that we read. He wishes Margaret's life moved according to a different grammar, making him indisposed toward hagiographical seeing and giving his blindness a textual-literary dimension. He cannot see that he is the antagonist in someone else's story. This height of profanity actually promises revelation. Paul the apostle catalogues the abuses he has undergone, calling himself a "spectacle" or theatron (1 Cor. 4.9). Building on this lament, John Parker describes this theatrical space as condemned to work out its salvation by way of an antichristian aesthetic. The martyr's theatron stages "the apparent absence of divine protection, or worse, the seeming license of demonic mimicry to parody the divine," yet it "actually promotes the faith in a coming fulfillment... As long as history lasts, divinity shall be like this: mediated by tragedy and the monstrous, by Leviathan and Behemoth, forgeries and farce, the godawful swirl of the whirlwind, the cross, and Antichrist. The Lord has approved this sort of temporal interference in an act of sublime artistry, or cunning-love, maybe." 88 Behemoth does indeed make an appearance in the "Life of St. Margaret." Not until the saint has been desolated by human persecutors do true monsters come forth.

Seeing the Invisible: Death, Doubt, and the Dragon

Were Margaret to die from her wounds, the SEL life would be a relatively straightforward, non-fantastic account of martyrdom, however stylized. The persecution-era martyr narratives tend to describe violence in realistic, if poeticized, tones, reserving miracles for the saints' relics. Some of the earliest examples of hagiographical texts were trial transcripts, and the willingness to die was considered extraordinary enough. By the thirteenth century, martyr narratives had become surreal, miracle-laden fantasias - a tone set by Prudentius's Liber Peristephanon (fourth c.) — which situated the passions within spiritualized landscapes. ${ }^{89}$ The 
first half of the SEL vita is noteworthy for its non-fantastic quality. Yet at the plot's nadir, something happens that changes the terms of both passion and text. At the "sight" of a saint tortured and hung on a tree, the text radically reorients its mode of depiction. The nebulous portrait of sainthood afforded by the first 150 lines - troubled by an iconoclastic impulse to convert the gaze - reaches a kind of vanishing point or singularity, subsequently introducing a style-shifting element of the fantastic. This spectacular intrusion of the supernatural overlays the saint entirely, removing her from "view." In one dramatic episode, the reader must accommodate both the temporary disappearance of Margaret and the appearance of an invisible realm. In order to definitively scandalize the corporeal imagination, the hagiographer presents readers with a vision of monstrosity. Margaret disappears from her own "theatron" entirely, swallowed by a manifestation of all that has worked against her: the dragon. Monster eclipses saint. Yet from this vanishing point, the text erupts into the gleaming spectacle of sanctity foreshadowed by the first half. ${ }^{90}$

The text begins again where it would appear to be finished. The first half of this vita takes Margaret to the brink of death. Before Margaret suffers execution, however, she undergoes a symbolic death. By reimagining death symbolically, mediated through a fantastic, mythical scene, the hagiographer can subject it to aesthetic investigation. No one can experience or testify to death, yet how can one understand the extent of Christ's conquest without some means of meditating on it? Early Christians met this challenge by imagining Christ's descent to the dead in vivid terms, exploring the activities of Christ, the souls bound in She'ol, and the demons who bind them. ${ }^{91}$ The hagiographer draws on this tradition, painting a descensus ad inferos into his vita. Poetic depictions of the descensus help push our notional conception of death to the limits of thinkability. Why do these moments of holy dying demand such fantastic, poetic interludes? 
"The danger is very real that we, as spectators of a drama beyond our powers of comprehension, will simply wait until the scene changes."92 Putting the question in dramatic, visual terms, Hans Urs von Balthasar contends that phenomena that remain invisible to us run the risk of being bracketed indefinitely. ${ }^{93}$

The supernatural makes its appearance-however present it has always been-only once Margaret is hidden from view. Olibrius returns Margaret to the "deop" and "derk" dungeon, where she sits alone, bemoaning her eviscerating wounds. ${ }^{94}$ This dungeon-possibly subterranean—functions as a kind of hell space. She sits there, out of sight. Margaret may now be invisible to others, but only here does an entire invisible realm expose itself to her gaze. This moment of extreme solitude elicits the first miracle in the vita. The saint cries out in agony over her wounds, and angelic beings rush to her aid:

pis maide lay in prison strong wel elinge al one Heo nuste of hure wonden to wan make hure mone Bote angles confortede hure and adoun to hure alizte ${ }^{95}$ Angelic ministry is a familiar motif in accounts of martyrdom. The church fathers made much of Paul's claim to have been made "a spectacle to the world, and to angels," so hagiographical depictions of angelic participation were less sentimental fancies than earnest theological statements (1 Cor. 4.9). Yet it is worth noting that this dungeon visitation affords the first glimpse at the supernatural agents invested in the success of God's athletes. That which the saint has taken on faith now becomes explicit. Yet the episode also betrays a longing for that which remains unseen. Literature can deliver what seems or is absent in spectacles of real suffering, providing a means of interpreting actual violence. As Elizabeth Castelli points out, this is exactly the function that cultic devotion to the martyrs was meant to perform. It preserved a collective memory of the dead while imbuing their deaths with meaning. Yet an "ethical ambivalence" 
haunts the cultural phenomenon of martyrdom, "where privileged meanings emerge only out of death." ${ }^{96}$ Hagiography weaves that supernatural affirmation back into the passion event itself. Margaret can and must receive the angelic aid that Christ himself refused (Matt. 26.53). These angelic ministrations - evidence of that which Margaret has seen with the eyes of faith - make the saint bold.

In order to defeat the idolatrous enemies surrounding her, Margaret, perhaps counterintuitively, asks that her enemy be made apparent to her. Not content with this vision of her allies, Margaret asks God "pat he sende hure som siztel Of pe deuel pat worrede hure" (emphases added). ${ }^{97}$ This request for a vision of her enemy constitutes the first instance of the saint's desire to see with her fleshly eyes. (As we will see, the corporeal nature of Margaret's interaction with the "vision" proves its fleshiness.) Margaret's desire to peer farther into the invisible realm occasions a representational crisis in the text and an epistemological crisis for the hagiographical "I." It seems Margaret is equipped to experience something that neither the hagiographer nor the reader can experience. Where she goes, we cannot follow. Rather than remain silent like the gospels, the vita becomes self-consciously literary. The SEL precedes the overtly didactic turn hagiography would take in the fourteenth and fifteenth centuries, preferring concretely rendered drama to abstract, devotional asides. This interlude proves a notable exception, however, with the narrator interrupting the flow of events not only to gloss them, but to comment on his own act of representation.

At its most spectacular, the imaginative vision of Margaret's vita becomes hardest to swallow; indeed, the vision seeks to do the swallowing. Foiling the interpretive capacity of our mind's eye, it affords a kind of "anti-image," "counterspectacle," or "counter-experience."98 This instance of monstrosity reflects a key moment in the logic of Pseudo-Dionysian apophasis. When 
the contemplative negates positive, intuitive images of the divine, he necessarily pauses on images that are startling, incongruous, and even monstrous. Why, for example, does scripture represent celestial beings in grotesque, chimerical forms? They would seem to debase that which they represent:

We cannot, as mad people do, profanely visualize these heavenly and godlike intelligences as actually having numerous feet and faces. They are not shaped to resemble the brutishness of oxen or to display the wildness of lions. They do not have the curved beak of the eagle or the wings and feathers of birds. We must not have pictures of flaming wheels whirling in the skies... The Word of God makes use of poetic imagery when discussing these formless intelligences... These pictures have to do with beings so simple that we can neither know nor contemplate them. ${ }^{99}$

Yet why represent the unrepresentable incongruously, he asks, rather than using more straightforwardly analogous imagery? Monstrous images better highlight the fact that there is no straightforwardly analogous imagery that can represent the immaterial. They spare us from "a passionate dependence upon images" while preserving the hidden things of God from the "unworthy." 100 This semantically jarring stop-gap is meant to push the mind upward toward the indescribable. Yet before this mental transcendence can occur, the mind's eye must experience something like repulsion. Although Pseudo-Dionysius protests that these poetic constructs are not for art's sake, he characteristically paints an elaborate word-picture that conjures mental images of the profanity he purports to avoid: "One would likely then imagine that the heavens beyond really are filled with bands of lions and horses, that the divine praises are, in effect, great moos, that flocks of birds take wing there or that there are other kinds of creatures all about..."101 What a fully realized menagerie! This heavenly zoo is irresistible, evoking the material paradise of Eden, where even the lowing of cattle gives praise.

The monstrous, while a necessary semantic inhabitant of the space in-between naïve mimesis and transcendent contemplation, proves unstable. Medieval thinkers also associated 
monstrosity (especially hybridity) with idolatry, man's attempt to improve upon nature.

Simulacra, or mimetic representations of real creatures, were permissible. ${ }^{102}$ Yet attempts to depict the divine occasionally worked against themselves, sometimes to scandalous effect. Three-headed depictions of the Trinity, though common, were condemned as monstrous and potentially heretical. ${ }^{103}$ Bestiaries tended to compare "the wonders of nature and the mystery of the incarnation," and some illuminations take these comparisons into the visual realm. ${ }^{104}$ Robert Mills has noted an incredible illustration of a bird-headed man in a cruciform posture. The meaning of this image remains unclear, but medieval writers often likened the God-Man's body to birds, such as the pelican and phoenix. ${ }^{105}$ An aesthetics of the monstrous affords expression to otherwise unimaginable aspects of the divine, but representing the mysteries of divinity always bears the whiff of idolatry. ${ }^{106}$ Idolatry is exposed as a shifting term for that which represents the divine in a questionable manner. The SEL "Margaret" dissects this loaded term, exploring traditional pagan idolatry and monstrous hybridity, all the while flirting with the implicit possibility that its protagonist — a textual icon - might prove an idol herself.

With the appearance of a dragon, the hagiographical gaze is put to the test and wavers here between doubt and faith. It undergoes a kind of conversion. The hagiographer introduces this episode as hearsay, subjecting himself to the conditions of hagiographical experience (Margaret "hurde telle" of Sts. Stephen and Lawrence): "Me telp pat pe deuel com to pis maide swie/ In pe forme of a dragon ac inot weper me lie" (emphases added). ${ }^{107}$ The dragon comes to the hagiographer through linguistic accounts (whether aural or textual) provided by others. $\mathrm{He}$ has received it in the testimony of other hagiographers, and it strikes him as untrue. Both Margaret (at the tale's start) and hagiographer have been "told" something incredible regarding sanctity. The hagiographer represents the saint's believing response to the reader, but will he 
himself believe? He confesses he knows not whether they lie. This hearing, or being-told, comprises the non-visual portion of witness: that of the Word received and believed. The Word is both the (counter)spectacle of Christ crucified and the faithful reception of the evangelion by way of his saints. Seeing the truth of this linguistically delivered Logos amounts to a vision of the invisible. Christ presents faith this way in the Parable of the Sower. Some receive the Word, and some do not. Those who do not receive the Word properly have not the "eyes to see," and, indeed, first it is necessary that they experience the ascesis of blindness (Matt. 13). Yet hagiography's prerogative - to represent invisible realities by way of fantastic spectaclecomplicates its injunction to believe.

Hagiographical doubt threatens to interrupt the narrative with the same skeptical I/eye that ruptured the saint herself. Perhaps more completely than the titillated sympathy evoked and shared by the hagiographer earlier, this moment of dubious gazing aligns him with his readers, ironically authenticating the less fabulous aspects of his account. Just as he was "told" something unbelievable, so does he recount that same unbelievable thing, but as unbelievable. By assuming and building his readers' incredulity into his account, though, he makes the dragon easier to "swallow." The rhetoric of doubt coats the rough kernel of this episode. The hagiographical gaze covers Margaret in a scaly mantle at the moment when her request for an apparition would render her point-of-view most critical. He crowds her out with first-person pronouns and contrary conjunctions (“ac," "but"):

Ac pis netelle ich nozt to sope for it nis nozt to sope iwrite Ac weper it is sop oper it nisi not noman pat wite Ac azen kunde it were pat pe deuel were to depe ibrozt For he nemai polie nannen dep I nemai it leue nozt And also I neleoue nozt pat is mizten were so stronge A so holy creature inis wombe auonge ${ }^{108}$ 
The hagiographer expresses anxiety about what is heard, what can be known, and what merits belief. On the one hand, the hagiographer suspends disbelief, confessing a state of unknowing ("whether it is true or not, no man knows"). On the other hand, he insists that the episode repels belief ("it is not written as truth," "he may not," "I may not believe it," "I do not believe that"). His primary objection is that this bit of hagiography is not recounted "to sope" ("as truth"). Despite all this, he decides to include the fantastic episode, depicting it in vivid terms.

This objection against the "telling" is superficially aesthetic, recalling the nature of Olibrius's doubt. As this chapter argues, hagiography's aesthetic concerns mediate and address theological ones. Something about this picture looks wrong to the hagiographer. It does seem a study in excess, painting a grotesque portrait of sanctity. What theological complications does this episode entail? What does not ring true? He offers a twofold objection. First, it is "against kind" that a devil could be brought to death. ${ }^{109}$ The word "kunde," related to "kin," refers to the "nature" of a thing and can double for the word. It seems unnatural that a spiritual entity should have its being terminated, suffering death. Second, he also cannot believe that a demon would possess the strength to take something holy into its "womb." 110 The gross materiality of this scene presents a conundrum about the natural and existential realities of invisible beings, specifically evil spirits. As it turns out, the hagiographer is right to be suspicious. This episode is thought to be a Western accretion and does not appear in older Greek accounts of St. Margaret (Marina, in the Eastern tradition). ${ }^{111}$ Some have suggested the influence of a wider folk tradition of tales about woman-serpent interaction. ${ }^{112}$ So while medieval readers in some way accepted the presence of miracles in saints' lives, this particular miracle violates even an "enchanted" view of reality. What purpose does it serve, then? If hagiography — the genre of "legend"-accomplishes anything in a postmodern world, it insists we conceive of truth more capaciously. A moment of 
female vulnerability, gratuitous materiality, and the exteriorization of interior things - is the dragon episode simply an extension of the tale's pornographic elements? Perhaps not. The true scandal of the dragon episode lies not in its fantastic visibility, but in its invisibility. While the other characters get to see Margaret's guts, Margaret herself is taken into a monstrous gutmomentarily seeing nothing and herself unseen.

The saint disappears entirely from view for the first time in this scene- not only from the reader's but also from the hagiographer's as well. He hands her over with great reluctance, but he does hand her over. For the space of a few lines, this is a saint's life without an apparent, appearing saint. It would be easy to ignore her temporary disappearance, bedazzled by an extended description of the act of swallowing, the dragon's fearfulness, and the hagiographer's uncertainties. Yet the dragon forces us to contend with death in another way: through epistemological doubt, aesthetic mortification, and the ascesis of invisibility. ${ }^{113}$ It is as if the hagiographer intrudes so much in order to fill the silence left by Margaret's absence. Margaret has become invisible - that is, if the reader envisions the scene as the hagiographer describes it. If profane gazing and iconoclastic rhetoric obstructed her glory before, now the base-level perceptibility of her body has been removed as well. Olibrius pulls a cloak over his face. Here, tradition pulls one over Margaret. We cannot regard her, even with a purified gaze; we must wait. This is the darkness of Holy Saturday. If the Cross gives us the face of death, the closed tomb conceals even that face. Reading this scene typographically does not elide the problem of the holy's invisibility. Rather, it locates a more original instance of that same scandal, one presumed by the logic of imitatio to inform every saint's life — and death.

When we compare illuminations of Margaret's eruption from the dragon's belly to images of Christ's Harrowing of Hell, a number of similarities emerge. Despite hagiographers' 
protestations, illuminators reveled in the grotesque corporeality of this miracle. Often Margaret emerges from an opening in the back or belly of a lovingly rendered dragon, and (as if to remind readers of the sordid route she took to get there) the hem of her garment sometimes dangles from the beast's jaws. Margaret's conquest of the "devil that worried her" takes the form of escape from the innards of a monster. The Harrowing's iconographic tradition may have inspired depictions of Margaret. Christ is often imagined as leading the virtuous patriarchs up out of the bowels of a beast. Hell is figured as organic, a creature whose jaws Christ pries open with his Cross. Informed by medieval illuminations, the $S E L$ provides readers with a vivid word-picture:

Me telp pat pe deuel com to pis maide swie In pe forme of a dragon ac inot weper me lie He zonede and gan is ouer cheke ouer hure heued do And is neper cheke and is tonge binepe at hure ho And forswolwyde so in pis maide he zonede er wel wide Heo wende into a sori wombe ac heo wolde lite abide For pe signe heo made of pe crois pe deuel barst anon And pis maide hol and sond out of pis worm gan gon ${ }^{114}$

This elaborate description of swallowing depicts the experience of death, but with the promise of resurrection already encoded within it. She went into his grievous womb but would abide only for a little ("ac heo wolde lite abide"). ${ }^{115}$ Just as Christ props Hell's jaws open with his Cross, so does "pe signe heo made of pe crois" cause the devil to burst open. ${ }^{116}$ Margaret invokes the Cross when she can see nothing else. This gesture stands against the rest of the vita as the one thing readers should not be able to see but are given anyway, for she makes it within the pit. If the Son of Man must be lifted up like the serpent, then his Cross proves a healing spectacle. Discerning the salvific potential of this moment of death purifies the gaze, preparing it to see all of reality. The martyrs join their deaths to this moment of salvation history, and their witness participates in that of the Cross. 
Margaret's request for a vision dramatically reverses the direction of gazing in the vita. Margaret, who has been the object of others' gazes, now trains her gaze on an object of its own. Once the gaze is reversed, saintly vision exposes the true nature of profane gazing as essentially demonic. The dragon episode sheds light on all antagonism the saint has faced. The persecuting, pornographic, and penetrative gazing, epitomized by Olibrius, reveals itself as no gaze at all. Rather, the profane gaze is a gigantic mouth. It desires not to behold, but to consume. The "jaws of death" epitomize hunger, and any mode of looking that devours participates in the destructive reality of death. The hagiographer overemphasizes the scale of the dragon's mouth, describing only its oral cavity and gastrointestinal system. He uses the verb "3onede” (yawned, gaped) twice, indicating the extent to which the dragon's anatomy stretches in order to consume Margaret. The "for-" prefix in "forswolwyde" derives from Old English and intensifies the verb it modifies, emphasizing the dragon's insatiability. Its mouth assumes exaggerated proportions: "he yawned and put his top jaw over her head and his bottom jaw and his tongue beneath her," "he gaped well wide." 117 (The "wideness" echoes that of Diocletian's servants as they search for Christians.) These jaws are almost apocalyptic, reminiscent, for example, of Ragnarok: "Fenrir's slavering mouth will gape wide open, so wide that his lower jaw scrapes against the ground and his upper jaw presses against the sky; it would gape still wider if there were more room." ${ }^{118} \mathrm{~A}$ world-eclipsing maw is the last thing Margaret sees before everything goes dark.

This moment of monstrous opacity ushers in the epiphanic second half of the vita. Margaret erupts from the dragon's "wombe." 119 The monster births the saint, making her supernaturally sourced power explicit. So much so that she undertakes to patronize women in labor, vowing to "bring pat child to sizt/ And al sauf of is moder wombe" if the mother prays to her. ${ }^{120}$ It is worth noting that she casts this service in visual terms. If the mother has faith, she 
will bring that which is unseen "to sizt." Margaret's midwifery reverses the dragon episode, in which the vision she has requested gives birth to her. Her request for a sign both indicates her belief in immaterial reality and calls it into question. Jesus famously rebukes the generation that seeks a sign. Yet he offers the enigmatic "sign of Jonah," which many theologians associate with the descensus. And, indeed, Margaret's request for a sign forces her to reenact the descensus, itself a manner of anti-sign. Even in its belly, she invokes Christ. ${ }^{121}$ This gesture of faith ruptures the sign, causing her to be reborn, or resurrected. ${ }^{122}$

Whatever doubt surrounds the act of representation, the very structure of depiction requires from both hagiographer and reader an act of faith. The act of faith is first and foremost aesthetic. The hagiographer takes the initiative to construct the tableau, attending to its image and translating it into verse. He invests "pis worm" with as much detail as his other creations, unsparing in craftsmanship. We know from the textual traditions of various lives that hagiographers frequently excised passages they found less than serviceable. The SEL compiler suffers the dragon to remain. Envisioning and reinscribing that which resists belief constitutes an act of low-level faith, even if it remains a purely imaginative exercise. It allows that which is unseen to appear, assumes that there is an unseen to appear. Artistic endeavor as a means of working out or performing faith addresses the question of medieval belief from an aesthetic, as opposed to a purely epistemological, angle. Hagiography encodes its own doubt, but it does so in order to nudge the lethargic devotee into more active belief in a world not immediately accessible to the senses. ${ }^{123}$

The second half of the vita begins with a second demonic apparition. This episode recasts all prior action in supernatural terms, but with some interesting reversals. Once Margaret has slain the dragon, a second devil appears. Margaret engages with this devil's mouth in a different 
way. Manifesting power instead of weakness, she replays and reverses the interrogation to which her human enemies submitted her, drawing answers up out of the devil's throat. If before she listened, now she orders, using violence to reinforce her demands:

pis maide aros wel baldeliche $\&$ gripte him bi pe honde pou hast heo sede inou ido pou ne sselt namore... Heo nom him bi is luper pol and harde him to gronde caste And hure rizt fot sette anon up is necke bihinde faste ${ }^{124}$

This scene inaugurates a triumphal second half. Like Perpetua, Agnes, Michael, the Virgin Mary, and many other saints, Margaret throws her adversary to the ground and "hure rizt fot sette anon up is necke bihinde faste," pinning it down. ${ }^{125}$ This was such a familiar motif that Prudentius could refer to Agnes's pes almus ("nourishing foot"). This image of a holy person with her foot on the devil's throat is an eschatological depiction of the final conquest of evil, heralding the general resurrection of which saints' bodies seemed to partake prematurely. ${ }^{126}$ Christ's Harrowing anticipates and ensures this final victory, so it is perhaps fitting that these two demonic confrontations follow one another in the text.

The demon reveals itself as the force animating and encouraging the saint's human enemies. When it begins to speak, its syntax recalls Olibrius's. It laments being cast down by a "hende" and "tendre maide." 127 She "scorgede him wel sore," punishing the demon in a manner recalling her own torture. ${ }^{128}$ Margaret directs her violence against an enfleshed evil spirit. Her violence is moderated, not the extreme, eviscerating forms of torture that English Christians associated with the Continent and their religious Others. Her first question is, "Wy worre ze Cristene men"? ${ }^{129}$ This demonic "worrying" of "Christian men" evokes the opening lines of the vita, in which the hagiographer describes the persecutions carried out against "Cristene men." Similarly, Margaret calls the demon a creature that "fleop aboute so wide," recalling the persecutors who "wende alonde wide" seeking Christians. ${ }^{131}$ Both the human and the demonic 
forces that put themselves against Christians have a capacious reach, emblematized by the serpent's yawning mouth.

In response to Margaret's questions, the demon relates a faux-origin story explaining the presence of demons in the world. It recounts a tale of yet another form of idolatry: worship of Mammon. It offers an apocryphal account of "kyng Salamon," who "ouercam us attelaste" by trapping all evil spirits in a "strong veteles (vessel)" and throwing them "in a putte (pit)."132 The enclosure and desolation of the demons mirrors Margaret's own forsakenness in the dragon's belly. For a short time during Solomon's rule, the world was free of evil spirits. Of course this does not last, and the impetus for this second Fall is humankind's "couetise of golde."133 The demon then describes a typical medieval hellmouth (such as the one in the Vale Perilous of Mandeville's Travels): “we gonne blowe \& blaste/ And brizt fur glowinde red out of pe eorpe caste." 134 The sulfuric pit affords another image of hell, less symbolic than the gaping mouth of the beast. The trapped demons produce their own light show. It succeeds in attracting the downward gaze of men. The demon describes this process using sight verbs, indicating that the first fall is that of the gaze toward the pit. Sure enough, "per come men" who "pis fur iseie pere" (emphasis added). ${ }^{135}$ Speculating that the fire heralds treasure, the men say "Lo... loke we anon" ("See... as we can see") and begin to dig. ${ }^{136}$ Seduced by the sight, the men speculate it might be “pat pere gret tresor" lies. ${ }^{137}$ If one's heart lies with one's treasure, then the heart of man is fixed on material gain. They break the vessel open, releasing demons back into the world. In some way, then, the root of all evil—especially the ills that "worry Christians" — can be traced to this original moment of profane gazing, imagined as a hungry, downward stare.

Saints seek to convert the gaze, but so do demons. The hagiographer employs a homograph of his favorite conversion word, using the past tense of "wene" to describe the men's 
state of mind. They "wende wel to cacche" ("thought for sure to obtain") the treasure within the vessel. ${ }^{138}$ This moment of thinking doubles as a turning toward greed, drawing on both senses of "wende." Human "wending," which occurs first in the heart, enables a demonic "wending" or "going out": "we were of prison ido/ And wende and fulde al pe eir aboue \& pus in euerich sidel We wendep \& deriep men in pe lond aboute wide" (emphases added). ${ }^{139}$ The language here echoes not only the language of interior conversion used by both Christians and pagans but also that of literal comings and goings - especially of the persecutors. Having obtained this information, Margaret “pis foule ping let wende," and the demon flies away. ${ }^{140}$ This notion of Satan as traveling far and wide might allude to Job, in which the juridical Satan of the Hebrew Bible tells God, "I have gone round about the earth, and walked through it" (Job 1.7). The hagiographer bolsters this parallel between demons' literal movement and the tyrant's attempts to turn Margaret's heart in the succeeding lines. The next day, Olibrius summons Margaret before him and "esste were hure wille were" and whether she has "turne hure pozt."141 Having survived her "wending" into the dragon's "wide" womb as well as having obtained an account of man's semi-original turn toward evil, Margaret has symbolically conquered the devils that worried her. ${ }^{142}$ After this fantastic interlude depicting a symbolic descent to the dead, the vita seems to begin again. Like the first half, the second half could stand on its own, but it would represent a different style of hagiography. The second summons before the tyrant also inaugurates a series of tortures. These tortures differ significantly from the torments that penetrated her body and rendered her irregardable in the first half. As with the first round, however, the gaze remains utterly implicated. 


\section{Seeing is Believing (or Not): Witnessing the Glorified Body}

The second half of the vita sheds its realism, depicting the miracle of saintly impassivity. The hagiographer now presents a martyr who seems superhuman, almost divine. Nothing can topple this figure, one who takes the time to build a cult to herself before allowing the executioner to free her soul. Is it possible aesthetically to render the invisible phenomenon of sanctification without it resembling idolization? As with the Resurrection of Christ, whose glorified body can walk through walls and disappear, Margaret's body should be read in light of the abject first half. The same reader who imagines this semi-divine being has just imagined her body leered at, eviscerated, and swallowed by a monster. The text functions like a diptych, with both versions of the story remaining in dialectical tension. This binocular portrait of a martyrdom exposes the invisible victory immanent in visible defeat. The SEL Margaret is relatively unique in its inclusion of both the brutalized and the impervious body, especially in its presentation of two separate passions. Having conquered death, at least symbolically, Margaret participates in the Resurrected body of Christ. Yet the Resurrection apparitions of Christ are fraught with misrecognition and doubt, whereas Margaret's post-descensus body assumes a hyper-visibility, saturated with unmistakable power. It resembles less the body in which Christ said "Do not touch me" than the glorified body that has ascended and will come again at the end of time. Her form anticipates the general resurrection. ${ }^{143}$ Belief in the power of saintly corporeality had many iterations: relic veneration, tomb shrines, incorruptibility, and miracles of physical contact or intervention. Unlike the first bout of torture, which brought Margaret to the brink of death, this second round has no effect. If the initial violence rendered her irregardable, this concluding violence discovers her inviolability. The theology of sanctification necessarily collapses humility and potency into one phenomenon, the latter sourced by God as the self-centeredness of the 
human person dissolves. The SEL hagiographer has split these realities into two disparate halves, separated by a symbolic commentary on spiritual vision and rebirth.

In the second half, Margaret's physical intactness reveals the inability of her soul to be "turned" or damaged, just as her torn form had exposed the profanity of her oppressor's gaze. Again Olibrius "strupe pe maide naked," hoping to recreate the illusory power he enjoyed previously. ${ }^{144}$ He casts her into a fire, but the fire goes out, leaving her "hol and sond." 145 The hagiographer uses the same formulation to describe her emergence from the dragon's belly: "pis maide hol and sond out of pis worm gan on." ${ }^{146}$ Margaret's actual flesh has undergone some kind of transfiguration, testifying to a supernatural reality. Fire failing, Olibrius binds her feet and hands and tosses her into deep waters; her bonds break, and she emerges unharmed. ${ }^{147}$ Determined "in som manere" to kill her, he prepares a vat of boiling water. ${ }^{148}$ Not only does the water fail to harm her but the earth also quakes "Swupe grisliche aboute" that people grow afraid. ${ }^{149}$ The earthquake recalls the earth's response to the moment of Christ's death. Whereas previously the hagiographer describes the torturers as "grislich," now Margaret and her attendant miracles are "grislich," inspiring an awe akin to dread ("drede"/"dradde"). ${ }^{150}$ This body, which can suffer no damage unless the saint wills it, grants readers and onlookers a foretaste of the glorified body doctrinally promised to them.

The display of intactness serves as Margaret's first public miracle, coming in the form of fantastic spectacle. The overdetermined exposure of Margaret's tortured body made her sanctity invisible, at least to those incapable of identifying it with the Cross. The tension between her holiness and such pretentious gazing resulted in her irregardability. She repelled onlookers' intentional gazes because they were profane (penetrative, idolatrous, pornographic, persecutorial), not looking but consuming. The ascesis afforded by this blindness, however, 
invites the gaze to revise itself - to convert. Having undergone blindness, the crowd is prepared for an explicit vision of her sanctity, for holiness to manifest as such. After Margaret's concluding prayer, for example, thunder and lightning rock the sky, causing many to "folle adoun for drede/ And leie pere as hi were astoned." 151 The response of heaven to Margaret's actions literally knocks them over. The spectacle of a "whole and sound" body resisting worldly onslaughts will reveal whose soul has been "turned" and whose resists. To what are they being converted? Not to the saint herself, but to her Christian faith. Margaret mediates this conversion.

The hagiographer acknowledges these miracles as a manifestation of God's power in a prayerful interjection: "Louerd muche is pi mizte as me may alday iseo" (emphases added). ${ }^{152} \mathrm{He}$ flags God's activity as a thing to be seen, and not just on rare, cataclysmic occasions, but "alday"- meaning all or every day. It is always available for those with eyes to see, immanent in daily reality. This gives the lie to the notion that only these spectacular miracles render Christ available to the crowd. Miracles only make the mundane fact of his presence explicit. The hagiographer's statement tellingly recalls two previous statements. He evokes and revises two earlier examples of seeing as objectification. This evocation with a difference affords yet another example of the hagiographer's chiasmic poetic. The true meaning of words and phrases becomes clear only at the end — often by undergoing inversion (or conversion)—with the monstrous interlude functioning as the vita's crux or turning point. As mentioned earlier, Margaret rejects the pagan idols "pat heo mizte aldai iseo."153 Later, Olibrius uses similar language to characterize Christianity's aesthetic offense as self-evident ("bicomp pe rizt nozt as pou mizt iseo"). ${ }^{154}$ The hagiographer highlights the incommensurability between this final vision of God's omnipotence and the idolatrous and pornographic seeing characterizing the first half. Precisely because Olibrius thinks he understands the Crucifixion, dwelling on its superficial appearance, he misses 
it entirely. As well, the idol fallaciously purports to comprehend an incomprehensible divinity, delivering the invisible up to the eyes. God's "might," however, gives all of reality its being and should be self-evident. That is, if one is really seeing. The spectacular manifestation of God's power as mediated by the saint exposes all other modes of seeing as blindness. Learning how to see a saint is learning how to see.

In contradistinction to Olibrius's enduring blindness, the text describes other characters whose eyes are opened. Both hagiographer and saint exhort onlookers really to see in this final scene. This true vision proves coincident with faith. The converted gaze reveals a converted soul, and it is impossible to place one before the other in either chronology or priority. "Vif pousond men in pe place po hi pis iseie/ Turnde anon to Cristendom and herede oure Louerd wel heie." 155 The first sentence relating mass conversion enjambs the thought at "iseie/Turnde." The one seems to begin precisely where the other ends, and yet there is no temporal rupture between them. They are two facets of one event. It is unusual in the SEL "Margaret" for a line break to occur in the midst of a sense unit, pushing the verb so far from the subject. It is also interesting that the crowd hears ("herede") the Lord as well as "seeing" his power. Hearing the Word of God, which Margaret does through the lives of the saints, amounts to answering an invisible call. God is not all spectacle; the Hebraic "small, still voice" requires an ascesis of vision, or a vision transcending literal eyesight. Christ is Word made flesh. Immediately after the hagiographer has said that anyone might see God at any time, thousands convert. ${ }^{156}$ Zooming from micro to macro, the text offers a specific example in the conversion of Maltus, Margaret's executioner. Margaret is brought out of the dungeon to "a manquellare [executioner] Maltus was is name/ He fondede hou he mizte lede pis maide mid mest ssame." 157 An arch-villain type, Maltus wonders how he can maximize Margaret's sense of shame. Despite this, he allows her to say a final prayer. Little 
does Maltus know that he has created space for the saint's final display of power. Though initially brutish, he sees the "lizt of heuene" all around her as she prays and begs her to let him "wende" to heaven with her. ${ }^{158}$ Maltus does a spiritual one-eighty, converting not only to Christianity, but to a desire for martyrdom (much like Margaret's own conversion). She commands him to perform his function, and he dies immediately upon doing so, presumably to join Margaret that day in paradise. Moments like these provided Christianity with an origin story, imagining its own dissemination in dramatic, miraculous, and almost inevitable terms. When Olibrius "isei" the people who "turned so," he martyred them as well. ${ }^{159}$ The converted participate in Margaret's witness, themselves becoming martyrs, multiplying the original act of witness exponentially.

\section{The Saintly Gaze as Prayer}

The saintly gaze is essentially prayer, and prayer is represented as a gaze. As in the early iconoclastic debates, the greatest claim for cultic devotion is that it directs the gaze ultimately to God. It may do so by way of the holy figure, but only because type participates in and indicates archetype. To see a saint properly is not to objectify and worship her, but to enter into her gaze, one anticipating the beatific vision. In the Legenda aurea, Jacobus de Voragine's entry for All Saints' Day explains this mediating function: “The saints make festival in heaven over us, for there is joy before the angels of God and holy souls over one sinner doing penance, and so we should make a fair return by celebrating their feasts on earth." 160 The saints are celebrated not for their own sake, but because they eternally celebrate any soul's turn toward God. If the profane gaze directs the eyes and soul downwards, the saintly gaze directs them upward.

These literal vectors function as poetic indicators of the soul's orientation. As soon as Maltus gives Margaret permission to say her prayers, "pis holy maide sat akneo \& to heuene 
hure eizen caste." 161 She then thanks God for bringing her to the point of martyrdom and requests that he allow her to patronize those who call on her in child labor, as well as anyone who builds an altar to her. These cult-making activities flow from her role as mediator, sharing in Christ's function as type shares in archetype. When she assumes the posture of prayer, she lifts her gaze to the sky instead of bowing her head. Earlier in the vita, immediately after her torture, "pe maide caste up hure eize."162 The saint's heavenward gaze demonstrates her habit of constant prayer, understood in a weak sense as the orientation of one's being toward God, or in a strong sense as intentional, heaven-directed thought. St. Margaret's popularity may stem from her close encounters with dragon and demon, but the bulk of her activity consists of prayer. At the beginning, she addresses God privately, seeking martyrdom ("Priveliche nizt and day in oure Louerd gan crie"). ${ }^{163}$ Every time something alarming happens, Margaret turns instinctively to God. The minute Margaret spies Olibrius approaching for the first time, she "gan to crie" to God. ${ }^{164}$ This prayer, like most in the text, is no passing invocation. It lasts seven lines, engaging in several modes: praise (remembrance of Christ's life), petition (that she withstand torture), plaint (evil men surround her), and so on. ${ }^{165}$ The first thing she does when summoned before the judgment seat is cross herself and "to oure Louerd al ire nom" ("give her anger to our Lord"), a prayerful gesture of self-abandonment. ${ }^{166}$ The hagiographer makes it clear through both Margaret's speech and her thought that she undertakes martyrdom as an act of worship motivated by "love." ${ }^{167}$ Understood in this light, every aspect of her passion becomes an expression of praise. In prison after her torture, she is "faste in orisons bidaie \& eke binizte." 168 Margaret's prayer for a vision initiates the dragon episode. We have already seen how the hagiographer brackets the wonders of the concluding scene with exclamatory prayer, glossing them for readers. ${ }^{169}$ Prayer is not just demonstrative, but rather a way of being. It is not one feature of 
sainthood, but a key feature of saintly identity, holy returning to holy. The more charity in the individual's relation to the divine, the more sanctification she undergoes. We might say that a saint's life concerns itself less with literal exemplarity—providing a template of desirable activity - than with exhorting readers to loving and contemplative relationality with God. This intimacy is realized through prayer, understood as the perfect gaze. It is the condition of possibility for sainthood.

Margaret herself signals prayer's centrality in her final orisons, highlighting the role of saint as intercessor. The prayer that converts Maltus differs from her prayers elsewhere in the text. In it, Margaret lays the foundation for her role as saintly intercessor, asking that those who pray to her in times of need might have their requests granted. Like Christ, she teaches others how to pray - to her. Margaret addresses God primarily, of course, yet the prayer's oral, public nature doubles its function. It both entreats and instructs others how to entreat. Its structure reduplicates that of the martyr's witness, which is both verbal and substantive. She asks that "Zif hi biddep in god entente grante hom milce \& ore/...3if hi biddep ping pat is to bidde grante hom for pe loue of me." ${ }^{170}$ Margaret seeks to patronize those who undertake cult-making activities. As a subject for meditation, her entire life assumes an intercessory quality, and one gets the feeling that the cult-making activities will themselves serve as answers to prayers, providing comfort and illumination. Margaret prays for "enimon" who "hap gode munde Louerd of mine liue" as well as anyone who raises a "chapel” or "weued" (altar), accoutrements of prayer. ${ }^{171}$ Margaret indirectly instructs the people how to build and furnish a cult, a cultural space for prayer directed and mediated by St. Margaret. Using the generic word "life," Margaret the character both performs and prophesies her sainthood. 
Is this idolatry? The protagonist's self-consciousness conflicts with Marion's claim that "holiness is unaware of itself." 172 To represent a saint as a saint is hagiography's purpose and its problem. In retroactively narrativizing the life of a saint, the hagiographer encodes self-conscious meaning within her actions and words. Yet saintly performance is also marked by the demands of artistic representation from the beginning. The first martyrs knew they were being hauled into a spectacular, dramatic setting — one with costumes, stage effects, and an audience. Conceiving of the audience in cosmic terms, they seem to have performed accordingly, producing spectacula Christiana to rival the spectacle of Roman power. ${ }^{173}$ The very project of hagiography presupposes that one's life can and must be a work of art. ${ }^{174}$ This assumption was likely shared by the first saints: the martyrs who died, placing their sufferings on a cosmic stage, a spectacle for angels and men. The hagiographer must make explicit, must represent, the logic of holiness. If Marion is right, that holiness is formally invisible and must be so in order to escape idolatry, then artistic representation of the holy, endowing the invisible with form, will always be fraught with danger. ${ }^{175}$ The Incarnation — as a theological doctrine, historical event, and social ethicprovided proponents of artistic representation and cultic devotion with their key defense. The material world had been redeemed; any bit of it could become sacramental or transfigured. Appreciating this without reifying that materiality depended upon the eye of the beholder, and that "eye" needed to be trained. As this chapter has sought to demonstrate, hagiography is aware of this and seeks to convert the gaze, enabling it to see materiality in Christic terms. Since late antiquity, hagiographers conceived of their task as sacred, self-consciously following the footsteps of the four evangelists. ${ }^{176}$ Margaret prays for any who "writ" or "ret" her life, always with "god entente." 177 The hagiographer has inscribed himself into the vita, putting himself into 
the saint's own mouth and under her patronage. His entire labor assumes the quality of prayer, since writing Margaret's life achieves her intercession.

Thus, the hagiographical gaze could be considered saintly recognition of the highest degree. It acknowledges sanctity and represents it so that it might be recognized by others. Through literary ingenuity, the hagiographer directs the soul toward the saints, who themselves direct it toward God. The ending makes this explicit: "Of gret uertue is hure lyf wo so peron po3t.../ Hit were god pat hi radde hure lyf pe sikerore ze seop it were." ${ }^{178}$ Her life, embodied and textualized, possesses virtue, understood as moral excellence and thaumaturgic power. This last line has been translated a number of ways, but my (relatively literal) translation is: "It would be a good thing if they read her life; it would be safer, you see." Wendy Larson's translation in Medieval Hagiography: An Anthology reads, "It is good that they read her life, for certainly it is the truth." ${ }^{179}$ Considering the hagiographer's theme, almost a structuring principle, of visuality, it makes sense to translate "seop" as the present plural form of "seo" (see). Having presented the saint's life, culminating in her own offering of that life as an aesthetic and intercessory phenomenon, the hagiographer concludes with "you see." This abrupt turn to the second person includes his readers among the onlookers within the text, making the same offer in textual form that the onlookers receive from the martyr herself. The second-person form of any verb would have achieved this sense of inclusion or implication; his choice of a sight verb specifies the manner of inclusion. It reminds readers that their gaze (literal, cognitive, and spiritual) must be carefully attended as well. Having taken his readers through scenes constituted in part by profane gazing - thereby implicating them in those modes of vision - the hagiographer has shown readers the stakes of envisioning sanctity. Moving them from a subject/object model to a participatory one, the hagiographer concludes by fulfilling this injunction to see by way of 
prayer. A gaze that sees so clearly has the potential to purify and heal that on which it looks. Perhaps for this reason, the SEL "Life of St. Margaret" concludes as follows: "Nou seinte Magarete pe holy maide we biddep attenende/ pat pou bidde for us pat we mote to pe ioie of heuene wende." ${ }^{\prime 80}$ The final lines are themselves a prayer to the saint, requesting first that she "attend," stretching her gaze over those who invoke her. The final word of this couplet, rhyming with "attend," is "wende." The ultimate goal of every prayer is nothing other than this final "wending," an upward motion to follow an upward gaze.

\section{Notes}

${ }^{1}$ Patricia Cox Miller, The Corporeal Imagination: Signifying the Holy in Late Ancient Christianity (Philadelphia: University of Pennsylvania Press, 2009) 115.

${ }^{2}$ Eds. Charlotte D’Evelyn and Anna J. Mill, The South English Legendary, Early English Text Society No. 235 (Oxford: Oxford University Press, 1956). (lines 126-128, 137-138); Like many who have worked on the SEL, I base my reading primarily on the Early English Text Society text, edited by Charlotte D’Evelyn and Anna J. Mill. This edition uses MS. Corpus Christi College, Cambridge, 145 as its primary source, supplementing with MS. Harley 2277. C 145 and H 2277 represent the most complete redactions available.

${ }^{3}$ Heather Blurton and Jocelyn Wogan-Browne, "Rethinking the South English Legendaries," Rethinking the South English Legendaries ed. Heather Blurton and Jocelyn Wogan-Browne (Manchester: Manchester University Press, 2011): "no two existing manuscripts of the $S E L$ are exactly alike, and the $S E L$ 's texts themselves appear in a wide variety of manuscript contexts" (8).

\footnotetext{
${ }^{4}$ Blurton and Wogan-Brown 9.
} 
${ }^{5}$ Anne B. Thompson, Everyday Saints and the Art of Narrative in the South English Legendary (Burlington, Vermont: Ashgate, 2003) 46.

${ }^{6}$ John Chrysostom, The Cult of the Saints, ed. Wendy Mayer (Crestwood, NY: St. Vladimir's Seminary Press, 2006) 222.

${ }^{7}$ Patricia Cox Miller, "Relics, Rhetoric and Mental Spectacles in Late Ancient Christianity," Seeing the Invisible in Late Antiquity and the Early Middle Ages, ed. Giselle de Nie, Karl F. Morrison, and Marco Mostert (Turnhout: Brepols, 2005): "In their own ways, all three of these authors [Victricius, Prudentius, Augustine] were, in effect, theorists as well as participants in the cult of relics, and all three 'saw' the invisible by using verbal imagery to express an abstraction, that is, the belief that relics were conduits of divine power" (28).

${ }^{8}$ See pp. 9-11 of the "Introduction." Jean-Luc Marion, "The Invisibility of the Saint," Saints: Faith Without Borders, ed. Françoise Meltzer and Jaś Elsner (Chicago: University of Chicago Press, 2011) 355-362.

${ }^{9}$ SEL 292 (line 7).

${ }^{10}$ SEL 292 (line 32).

${ }^{11}$ SEL 293 (lines 35-36).

${ }^{12}$ SEL 293 (line 36).

${ }^{13}$ SEL 292 (line 14).

${ }^{14}$ SEL 292 (lines 14-15, 17).

${ }^{15}$ SEL 292 (lines 19).

${ }^{16}$ SEL 292 (line 8).

${ }^{17}$ SEL 295 (line 104). 
${ }^{18}$ Michael Camille, The Gothic Idol: Ideology and Image-making in Medieval Art

(Cambridge: Cambridge University Press, 1989) 240.

19 SEL 294 (line 79).

${ }^{20}$ Larissa Tracy, Torture and Brutality in Medieval Literature: Negotiations of National Identity (Rochester: D. S. Brewer, 2012) 52.

${ }^{21}$ Tracy 32; See also John Frankis, “The Social Context of Vernacular Writing in Thirteenth-century England: the Evidence of the Manuscripts" in Blurton and Wogan-Browne, eds., Rethinking the South English Legendaries 66-83.

22 Tracy 22.

23 Tracy 32.

24 Tracy 40.

${ }^{25}$ Camille 13.

${ }^{26}$ Miller, The Corporeal Imagination 7.

${ }^{27}$ Camille 220-241.

${ }^{28}$ Robert Bartlett, Why Can the Dead Do Such Great Things? Saints and Worshippers from the Martyrs to the Reformation (Princeton: Princeton University Press, 2013): "During the disputes over the status of the Virgin Mary in the 420s, the patriarch Nestorius (later condemned as a heretic) warned, 'do not make the Virgin a goddess.' It was not an unfounded worry” (162).

${ }^{29}$ SEL 292 (line 1).

${ }^{30}$ SEL 294 (line 92).

${ }^{31}$ SEL 292 (lines 9-11).

${ }^{32}$ SEL 293 (line 38). 
${ }^{33}$ For a study of how exemplarity changes after Constantine, see Catherine Sanok, Her Life Historical: Exemplarity and Female Saints' Lives in Late Medieval England (Philadelphia: University of Pennsylvania Press, 2007); See also Elizabeth Allen, False Fables and Exemplary Truth: Poetics and Reception of Medieval Mode, The New Middle Ages (London: Palgrave Macmillan, 2005).

34 Tracy 45.

35 Tracy 47.

36 Tracy 47-48.

${ }^{37}$ Aviad Kleinberg, "Apophthegmata” in Elsner and Meltzer, eds., Saints: Faith Without Borders 396.

${ }^{38}$ Patricia Cox Miller, "Subtle Embodiments: Imagining the Holy in Late Antiquity," Apophatic Bodies: Negative Theology, Incarnation, and Relationality, ed. Chris Boesel and Catherine Keller (New York: Fordham University Press, 2009) 45.

${ }^{39}$ Pseudo-Dionysius, “The Mystical Theology” in Pseudo-Dionysius: The Complete Works, trans. Colm Luibheid (New York: Paulist Press, 1987) 138; This aesthetic of dark holiness culminates in "La noche oscura del alma" by John of the Cross. John of the Cross, "The Dark Night" in The Collected Works of St. John of the Cross, trans. Kieran Kavanaugh, O.C.D. and Otilio Rodriguez, O.C.D. (Washington D.C.: ICS Publications, 1991): “O guiding night!/ O night more lovely than the dawn!/ O night that has united/ the Lover with his beloved,/ transforming the beloved in her Lover" (359).

${ }^{40}$ Andrew Louth, “'Truly Visible Things Are Manifest Images of Invisible Things': Dionysios the Areopagite on Knowing the Invisible" in de Nie, Morrison, and Mostert, eds., Seeing the Invisible in Late Antiquity and the Early Middle Ages 23. 
${ }^{41}$ SEL 292 (lines 27, 29).

${ }^{42}$ SEL 292 (line 25).

${ }^{43}$ SEL 292 (lines 25, 27, 28, 29).

${ }^{44}$ SEL 292 (lines 26, 28, 30).

${ }^{45}$ Incidentally, this hyper-aggressive history of persecution is partly revisionist. Christian communities did suffer persecution, but these "round-ups" were sporadic and by no means systematic. However, the spectacle of such executions may have been traumatic enough for Christians to remember those early centuries as mostly hostile. In any case, martyrdom provides the first, most original template of Christian sanctity. See Candida Moss, The Myth of Persecution: How Early Christians Invented a Story of Martyrdom (New York: HarperOne, 2014).

${ }^{46}$ John Chrysostom, "Homily 2 on the Maccabees," The Cult of the Saints: St. John Chrysostom 149.

${ }^{47}$ Karen Winstead, Virgin Martyrs: Legends of Sainthood in Late Medieval England (Ithaca: Cornell University Press, 1997): "One obvious source of appeal is the virgin martyr legend's emphasis on sex, violence, and sexual violence... [T] he virgin martyr legend offers a heroine who is invariably young, beautiful, and endangered by sexual predators. Her narrow escapes from brothel and boudoir provide moments of suspense, while the torments she does not evade are rendered palatable — possibly even enjoyable — by their necessity and by the certainty of her body's ultimate miraculous restoration. The virgin martyr legend thus affords a safe distance from which to indulge 'innocent' escapism as well as less innocent fantasies of 'harmless' violence against women” (12); Maud Burnett McInerney, Eloquent Virgins from Thecla to Joan of Arc (New York: Palgrave Macmillan, 2003): “The plot of the narrative 
becomes formulaic, and one of its constitutive elements is the threat of rape, never fulfilled" (75).

${ }^{48}$ SEL 295 (line 111).

${ }^{49}$ SEL 292 (line 28).

${ }^{50}$ SEL 293 (lines 43, 44).

${ }^{51}$ SEL 293 (lines 36, 54).

${ }^{52}$ SEL 293 (lines 60).

${ }^{53}$ SEL 293 (line 61).

${ }^{54}$ SEL 294 (line 78).

${ }^{55}$ SEL 292 (line 8).

${ }^{56}$ SEL 294 (lines 79-82).

${ }^{57}$ Rachel Fulton Brown, From Judgment to Passion: Devotion to Christ and the Virgin Mary, 800-1200 (New York: Columbia University Press, 2005) 104.

${ }^{58}$ E. P. Sanders The Historical Figure of Jesus (London: Penguin Books, 1993): "But knowledge of Jesus was limited to knowledge of Christianity; that is, had Jesus' adherents not started a movement that spread to Rome, Jesus would not have made it into Roman histories at all" (50).

${ }^{59}$ See Sarah Salih, Versions of Virginity in Late Medieval England (Woodbridge, Suffolk: D. S. Brewer, 2001).

${ }^{60}$ SEL 294 (line 87).

${ }^{61}$ SEL 295 (line 101).

${ }^{62}$ SEL 295 (line 111). 
${ }^{63}$ See Michael Roberts, Poetry and the Cult of the Martyrs: The "Liber Peristephanon" of Prudentius (Ann Arbor: University of Michigan Press, 1993) 99.

${ }^{64}$ Camille 42.

${ }^{65}$ SEL 295 (line 112).

${ }^{66}$ SEL 295 (line 116).

${ }^{67}$ SEL 295 (line 110).

68 SEL 296 (lines 144-145).

${ }^{69}$ See Nancy J. Vickers, "Diana Described: Scattered Woman and Scattered Rhyme,” Critical Inquiry 8 (1981): 265-279.

${ }^{70}$ For a discussion of queer blazonry, see Richard Rambuss, "Pleasure and Devotion: The Body of Jesus and Seventeenth-Century Religious Lyric,” Queering the Renaissance, ed. Jonathan Goldberg (Durham: Duke University Press, 1994) 253-279; Richard Rambuss, Closet Devotions, Series Q (Durham: Duke University Books, 1998).

${ }^{71}$ SEL 295-296 (lines 116-125).

${ }^{72}$ SEL 296 (lines 122, 125).

${ }^{73}$ The virgin martyr legend emerged over time, a slow homogenization of a diverse array of martyr stories. See Elizabeth Castelli, Martyrdom and Memory: Early Christian CultureMaking, Gender, Theory, and Religion (New York: Columbia University, 2007).

${ }^{74}$ SEL 293 (line 47).

${ }^{75}$ SEL 296 (line 135).

${ }^{76}$ SEL 295-296 (lines 101, 132).

${ }^{77}$ Jean-Luc Marion, Being Given: Toward a Phenomenology of Givenness, trans. Jeffrey L. Kosky (Stanford: Stanford University Press, 2002) 215. 
${ }^{78}$ SEL 296 (lines 127-128).

${ }^{79}$ SEL 296 (line 137).

${ }^{80}$ SEL 293 (line 65).

${ }^{81}$ SEL 296 (lines 138-140).

${ }^{82}$ SEL 296 (line 148).

${ }^{83}$ SEL 296 (line 147).

${ }^{84}$ SEL 296 (line 133).

85 SEL 296 (lines 141-142).

${ }^{86}$ SEL 296 (line 133).

${ }^{87}$ SEL 296 (line 142).

${ }^{88}$ John Parker, The Aesthetics of Antichrist: From Christian Drama to Christopher Marlowe (Ithaca: Cornell University Press, 2007) 41-42.

${ }^{89}$ Miller, "Relics, Rhetoric and Mental Spectacles in Late Ancient Christianity" in de Nie, Morrison, and Mostert, eds., Seeing the Invisible in Late Antiquity and the Early Middle Ages 38 .

${ }^{90}$ Wendy R. Larson, ed. and trans., "Three Thirteenth-Century Lives of St. Margaret of Antioch," Medieval Hagiography: An Anthology, ed. Thomas Head (New York: Routledge, 2001): "Although the dragon scene in Margaret's life met with ecclesiastical disapproval, it could not be easily removed from the legend. The dragon is featured in Margaret's iconography, and the saint's safe emergence from the dragon's split womb also became associated with her role as patroness of women in childbirth" (676).

${ }^{91}$ Hans Urs von Balthasar, Mysterium Paschale, trans. Aidan Nichols, O.P. (London: T\&T Clark, 1990): "the mid-point of this restorative action is necessarily the place of the original rupture: death, Hades, lostness far from God" (12). 
${ }^{92}$ Balthasar, Mysterium Paschale 50.

${ }^{93}$ Balthasar 151.

${ }^{94}$ SEL 294 (line 91).

${ }^{95}$ SEL 297 (lines 151-153).

${ }^{96}$ Castelli 9.

97 SEL 297 (lines 155-156).

98 The terms belong to Camille (The Gothic Idol), Burrus, and Marion (Being Given), respectively. Virginia Burrus, The Sex Lives of Saints: An Erotics of Ancient Hagiography, Divinations: Rereading Late Ancient Religion (Philadelphia: University of Pennsylvania Press, 2007).

${ }^{99}$ Pseudo-Dionysius 148.

${ }^{100}$ Pseudo-Dionysius 148.

${ }^{101}$ Pseudo-Dionysius 148.

102 The Book of John Mandeville draws an explicit distinction between idols and simulacra. Sarah Salih, "Idols and Simulacra: Paganity, Hybridity and Representation in Mandeville's Travels," The Monstrous Middle Ages, ed. Bettina Bildhauer and Robert Mills (Cardiff: University of Wales Press, 2003) 121.

${ }^{103}$ Robert Mills, “Jesus as Monster” in Bildhauer, ed., The Monstrous Middle Ages 38.

${ }^{104}$ Mills, "Jesus as Monster" 35.

105 Mills, "Jesus as Monster" 48.

${ }^{106}$ In an interesting contemporary analogy, Marion has argued that metaphysical discourse is idolatrous in its impulse to explicate and define God. Jean-Luc Marion, God Without Being, trans. Thomas A. Carlson (Chicago: University of Chicago, 1991). 
${ }^{107}$ SEL 297 (lines 156-157).

108 SEL 297 (lines 165-170).

${ }^{109}$ SEL 297 (line 167).

110 SEL 297 (lines 169-170).

${ }^{111}$ Lois Drewer, "Margaret of Antioch the Demon-Slayer, East and West: The Iconography of the Predella of the Boston Mystic Marriage of St. Catherine," Gesta 32.1 (1993): 11-18; Monica White, “The Rise of the Dragon in Middle Byzantine Hagiography," Byzantine and Modern Greek Studies 32.2 (2008): "In late antique hagiography, dragon-slaying episodes tended to be minor miracles. When, however, these vitae were rewritten in the ninth century and later, the combat was usually given more attention, often at the expense of other miracles. The defeat of the dragon thus became a new focal point of the stories and, in some cases, the miracle for which the saint was most famous" (150).

${ }^{112}$ Karen Smith, "Snake-Maiden Transformation Narratives in Hagiography and Folklore," Fabula 43.3 (2002): 251.

${ }^{113}$ Elaine Scarry, The Body in Pain: The Making and Unmaking of the World (Oxford: Oxford University Press, 1987): "To have pain is to have certainty; to hear about pain is to have doubt" (13).

${ }^{114}$ SEL 297 (lines 157-164).

115 SEL 297 (line 162).

${ }^{116}$ SEL 297 (line 163).

117 SEL 297 (lines 159-161).

${ }^{118}$ Kevin Crossley-Holland, The Norse Myths (New York: Pantheon Books, 1980) 174. ${ }^{119}$ SEL 297 (lines 162, 170). 
${ }^{120}$ SEL 301 (lines 285-286).

${ }^{121}$ SEL 297 (line 163).

${ }^{122}$ See Renate Blumenfeld-Kosinski, Not of Woman Born: Representations of Caesarean Birth in Medieval and Renaissance Culture (Ithaca: Cornell University Press, 1990).

${ }^{123}$ See Steven Justice, "Did the Middle Ages Believe in Their Miracles?"

Representations 103 (2008); See Steven Justice, "Eucharistic Miracle and Eucharistic Doubt," Journal of Medieval and Early Modern Studies 42.2 (2012).

${ }^{124}$ SEL 297 (lines 174-175, 177-178).

${ }^{125}$ SEL 297 (line 178).

${ }^{126}$ Caroline Walker Bynum, The Resurrection of the Body in Western Christianity, 2001336 (New York: Columbia University Press, 1995).

${ }^{127}$ SEL 298 (lines 184, 186).

${ }^{128}$ SEL 298 (line 183).

${ }^{129}$ SEL 298 (line 195).

${ }^{130}$ SEL 297, 298, 292 (lines 156, 195, 25, 28, 30).

${ }^{131}$ SEL 298, 292 (lines 194, 27).

${ }^{132}$ SEL 298 (lines 203, 206, 207).

${ }^{133}$ SEL 298 (line 212).

${ }^{134}$ SEL 295 (lines 110-111).

${ }^{135}$ SEL 295 (line 112).

${ }^{136}$ SEL 299 (line 217).

${ }^{137}$ SEL 295 (line 113).

${ }^{138}$ SEL 299 (line 221). 
${ }^{139}$ SEL 299 (lines 224-226).

${ }^{140}$ SEL 299 (line 231).

${ }^{141}$ SEL 299 (line 235).

142 SEL 297 (lines 161-162).

${ }^{143}$ Bynum: "The specific adjectives, analogies, and examples used in treatises on resurrection suggest that the palpable, vulnerable, corruptible body Christ redeems and raises was quintessentially the mutilated cadaver of the martyr" (43).

${ }^{144}$ SEL 299 (line 238).

145 SEL 299 (lines 238-240).

${ }^{146}$ SEL 297 (line 164).

${ }^{147}$ SEL 300 (lines 241-244).

${ }^{148}$ SEL 300 (lines 246-247).

149 SEL 300 (lines 249-250).

${ }^{150}$ SEL 295, 300-302 (lines 110, 250, 291, 310).

${ }^{151}$ SEL 301 (lines 291-292).

${ }^{152}$ SEL 300 (line 253).

${ }^{153}$ SEL 292 (line 8).

${ }^{154}$ SEL 294 (line 78).

155 SEL 300 (lines 255-256).

${ }^{156}$ SEL 300 (line 253).

157 SEL 300 (lines 261-262).

${ }^{158}$ SEL 302 (line 305).

159 SEL 300 (lines 257-258). 
${ }^{160}$ Jacobus de Voragine, "All Saints Day," The Golden Legend, trans. William Granger Ryan (Princeton: Princeton University Press, 2012) 660.

${ }^{161}$ SEL 301 (line 268).

162 SEL 296 (line 134).

${ }^{163}$ SEL 292 (line 32).

${ }^{164}$ SEL 293 (line 51).

165 SEL 293 (lines 52-58).

166 SEL 295 (line 97).

${ }^{167}$ SEL 295 (line 98).

${ }^{168}$ SEL 297 (line 154).

${ }^{169}$ SEL 300 (line 253).

${ }^{170}$ SEL 301 (lines 277, 282).

${ }^{171}$ SEL 301 (lines 274, 279, 280).

172 Marion, "Invisibility of the Saint" 356.

${ }^{173}$ Castelli 117.

${ }^{174}$ With the rise of new modes of sanctity, certain individuals began to live their lives aware of the fact that they might be remembered as saints. See Aviad M. Kleinberg, Prophets in Their Own Country: Living Saints and the Making of Sainthood in the Later Middle Ages (Chicago: University of Chicago Press, 1992).

${ }^{175}$ Marion, "The Invisibility of the Saint" in Elsner and Meltzer, eds., Saints: Faith Without Borders.

${ }^{176}$ See Derek Krueger, Writing and Holiness: The Practice of Authorship in the Early Christian East (Philadelphia: University of Pennsylvania Press, 2011). 
${ }^{177}$ SEL 301 (line 276).

${ }^{178}$ SEL 302 (lines 316-318).

${ }^{179}$ Wendy Larson, "Three Thirteenth-Century Lives of St. Margaret of Antioch,” Medieval Hagiography: An Anthology (London: Routledge, 2001) 691.

${ }^{180}$ SEL 302 (lines 319-320). 


\section{CHAPTER TWO}

\section{Saints and Salvation in The Book of John Mandeville}

...the holy man was deliberately not human. He was the 'stranger' par excellence.

-Peter Brown ${ }^{1}$

The Book of John Mandeville tells of a knight-errant named Sir John who undertakes a pilgrimage to Jerusalem. On his way, he stops in a Greek town named Stagira. The pilgrim cares about Stagira for one reason: Aristotle was born and "y-grave" in it. ${ }^{2}$ Medieval thinkers admired Aristotle so much, they referred to him simply as "the philosopher." The narrator shares this enthusiasm, quoting him in the opening Prologue. Medieval cartographers situated Jerusalem at the world's center. Sir John argues, rather tautologically, that this proves Jerusalem's priority among earthly locales. He appeals to Aristotle, noting that "therefore seith the philosofre thus: virtus rerum in medio consistit." ${ }^{33}$ Sir John appropriates and re-contextualizes Aristotle's words, using them to valorize a Judeo-Christian geography in which Jerusalem's "middle-ness" indicates its virtue. None of this is surprising. Late medieval theology owed its philosophical vocabulary to Aristotle's vast corpus. ${ }^{4}$ The next time the narrative invokes Aristotle, it does so on the philosopher's own turf. In Stagira, however, Aristotle's corpse speaks for itself.

The philosopher's grave radiates power. Sir John watches with amazement as Stagirans venerate his remains, enacting graveside rituals:

And at Strages was Aristotle y-grave, and ther is an auter uppon his tumbe. And ther they make a greet feste every yer als though he were a seynt. And uppon his auter they holden greet conseylis. And they trowth that thorgh inspiracioun of God and of hym they shal have the better consail. ${ }^{5}$

These devotees, probably Orthodox Christians, treat Aristotle "als though he were a seynt." Canonized by popular acclaim, Aristotle enjoys all the trappings of a cult following. The locals "make a greet feste every yer" in his honor. Most named saints had a spot on the calendar, yet 
only the most beloved patrons had significant festivals associated with their cults. The "auter uppon his tumbe" testifies most powerfully to Aristotle's quasi-saintly status. Saint cults formed around the bodies of the first martyrs, whose graves served as a nexus for devotional praxis. This intimacy with dead bodies violated pagan taboos but lay at the heart of Christian saint cults. ${ }^{6}$ Most striking of all, supernatural forces appear to confirm Aristotle's sanctity. Stagirans "holden greet conseylis" at his tomb, believing that "thorgh inspiracioun of God and of hym [Aristotle] they shal have the better consail." This custom implies two radical assumptions: first, that Aristotle has the intercessory powers attributed to Christian saints, and, second, that it pleases God to work "thorgh" a pagan. His grave has become a locus of sacred power, where the dead mediate between this world and the next. ${ }^{7}$ Whether those memorializing Aristotle actually consider him a saint remains unclear. The subjunctive clause "als though he were a seynt" could indicate a situation in which sainthood functions as an analogue, or it could signal a kind of informal canonization. Whatever the case, the Mandeville-author makes an aesthetic and conceptual choice to describe this phenomenon using the language of cultic devotion.

Sainthood renders the spectacle legible. It provides a template with which to encounter religious and cultural difference. Aristotle's cult affords just one example among many. Throughout The Book, the Mandeville-author interprets strange practices-especially those regarding the sacred - through a hermeneutic of sainthood. Saints provide a pattern of attention, a means of viewing "diverse folk" with an eye that seeks the form of sanctity. ${ }^{8}$ Sir John identifies as a pilgrim, which makes his telos, by definition, the holy. The Book's contents reflect this. The narrative constantly waxes hagiographical—citing, alluding to, invoking, or somehow recalling various saints. A partial litany includes: Alban, Michael, Sophia, Justinian, Dismas, Helen, Constantine, Peter, Anne, John Chrysostom, Luke, George, Nicholas, John of Patmos, Paul, 
Hilarion, Bernard, the Virgin Mary, James, Barbara, Catherine, Jerome, Joseph, Mary Magdalene, Benedict, Stephen, John the Baptist, Thomas, Elizabeth, Simon, Thecla, Theodosius, Silvester, Andrew, Gabriel, Augustine, Gregory, Eustace, Athanasius. The word "seynt" occurs on its own as well. Though usually appended to a proper name, the Mandeville-author also uses the word to discuss cultic devotion in the abstract and to describe non-Christian religious praxes. His mode of reference proves as diverse as it is rich. The saints serve his descriptive enterprise in numerous ways and are perhaps even constitutive of it. It might seem strange that a thinker so intrigued by religious difference would discover in this orthodox Christian tradition a touchstone for interreligious contact. By the fourteenth century, sainthood had solidified into a complex and elite institution. For the most part, only religious orders had the financial and scholarly wherewithal to advance a cause, and every canonization required the pope's approval. ${ }^{9}$ Yet holiness — the essence of sainthood—remained radically mysterious.

If institutional sainthood is subject to delimitation, sanctity itself escapes it. Holiness (synonymous with sanctity) retains semantic flexibility by right. Its reification would be tantamount to idolatry. The holy does not conform to an ideology or paradigm. Anyone who offers a totalizing articulation of the holy sets himself up as the standard by which to measure it. "Holy" means "set apart." Everything else is profane (pro fanum, "outside the temple"). God alone is holy, according to the Judeo-Christian scriptures. ${ }^{10}$ One contemporary phenomenologist argues that God's absolute alterity imposes itself precisely as his holiness. ${ }^{11}$ Sanctity marks sacred difference. Yet the imperative "be thou holy" accompanies God's own proper holiness. ${ }^{12}$ This opens up the possibility of sanctification: God's conferring of his holiness on human persons. The transfer of this irreducibly mysterious quality endows sanctified persons with an incomprehensibility of their own. As a cultural form, sainthood has various aesthetic and 
structural features that allow Sir John to recognize it. As a spiritual phenomenon, however, it must remain mysterious. Thomas Aquinas describes it as the orientation of one's being toward the divine. ${ }^{13}$ How to recognize something so indeterminate, especially when the symbolic structures that render it perceptible grow increasingly alien? This binocular quality, in which form and spectacle overlay cognitive darkness, makes sainthood the perfect technology with which to view non-Catholic and non-Christian religiosity. Unknowing keeps the concept of sainthood open, while the traditional elements of cultic devotion cue the spectator (or reader) to the presence of a saint. Throughout The Book, the constant variable of sainthood enables Sir John to recognize sanctity in Others. Conversely, these strange sanctities reveal the uncanniness inherent in all saints, who baffle as often as they instruct. Saints hold contradictory things in tension, paradoxically reconciling opposites without collapsing them. ${ }^{14}$ This opens up a space of soteriological possibility.

The Mandeville-author's insistence on the universality of sainthood leads him into daring, hopeful statements about the salvation of non-Christian peoples. The manuscript tradition reflects this passion. The Book turns up in several interesting collections, including "an 'Olympian' compilation of works concerning salvation history and missions to the non-Christian peoples." 15 The text presents itself as an entertaining account of "diverse schap of men and of beistis," but it constitutes a work of vernacular "imaginative theology" as well. ${ }^{16}$ Nicholas Watson has observed that vernacular theology tends toward universalism. ${ }^{17}$ No medieval text could overtly affirm universalism without being condemned as heretical. The Book can only insinuate it by way of unknowing. Sir John famously says that "we wyteth [know] noght wham God loveth most, and wham he hateth most." The Mandeville-author negates the possibility of certain knowledge ("wyteth noght"), which effectively affirms the possibility of a more universal 
salvation. ${ }^{18}$ Beyond the boundaries of the visible church lies the epistemological no-man's-land of the invisible church. This inclusive impulse occurs within a space of unknowing. It has to. If holiness resists comprehension, then who can definitively proclaim upon the sanctity of another? The opacity of holiness unites the possibility of universal salvation with apophatic, or negative, theology.

Apophatic theology saturated medieval English thought. Its most authoritative text, the Mystical Theology of Pseudo-Dionysius (fifth-sixth c.), "ran through England like the wild deer," according to one chronicler. ${ }^{19}$ Thomas Aquinas refers to Pseudo-Dionysius around 1,760 times in his Summa. ${ }^{20}$ Apophatic thought was more than in the air by the time the Mandeville-author was writing. This mode of theological discourse emphasizes God's ineffability, enjoining believers to negate statements about the divine. Such negation does not imply falsity, but signals a higher, transcendent reality. By defamiliarizing traditionally received ways of thinking about God, one might better understand God's absolute otherness. The via negativa complements the cataphatic (affirmative, positive) tradition, which emphasizes God's immanence in Christ and the sacraments. ${ }^{21}$ Scholars have tended to focus on apophatic theology's influence on the contemplative tradition. ${ }^{22}$ My project shifts the focus to the literature of sainthood. ${ }^{23}$ The inscrutability of holiness imbues medieval representations of sanctity with a poetics of apophasis. Moments of opacity, invisibility, darkness, indeterminacy, and repulsion occur repeatedly within depictions of sainthood. These topoi frustrate the mental gaze in its attempt to envision the saint. This apophatic poetic both avoids the sin of cognitive idolatry and preserves the intrinsic ineffability of holiness. It is worth dwelling on the shadows cast by such an otherwise spectacular genre. They create a space of possibility, wherein things like universal salvation become thinkable. 


\section{Hagiography and The Book}

The Book of John Mandeville has both a dynamic and diffuse textual history. It was a bestseller, translated from the original Anglo-Norman into at least nine other languages. ${ }^{24}$ The Book has a notoriously diffuse manuscript tradition. Around three hundred manuscripts survive, varying from one another to different degrees. ${ }^{25}$ Because of this radical instability, Iain Macleod Higgins has suggested we refer to it as "the mandevillean multi-text." 26 Its popularity inspired constant transcription, translation, and alteration. ${ }^{*}$ Nineteenth-century scholarship revealed the dramatic degree to which The Book is a composite text, cobbling together bits of Pliny, Marco Polo, Odoric of Pordenone, William of Boldensele, and others under a fraudulent claim to eyewitness testimony. ${ }^{27}$ The pilgrim-knight Sir John of Mandeville is as much a fiction as the dog-headed men he claims to have seen. The Book seems to have been compiled by a cleric, possibly a Dominican who would have felt kinship with the friars from whose texts he borrowed, such as the Dominican William of Boldensele (Book of Certain Regions Beyond the Mediterranean), the Dominican Pseudo-William of Tripoli (Treatise on the State of the Saracens), and the Franciscan Odoric of Pordenone (Account [of travels in China]). The first half of the narrative instructs Western Europeans about how to make a pilgrimage to the Holy Land. Mandeville provides various routes and gives colloquial advice about what to see when in Jerusalem. The second half shifts our gaze from the medieval center of the world to the periphery, cataloguing the so-called "marvels of the East."

For many reasons, The Book can be hard to take seriously. And no surprise: once the pilgrim-knight leaves Jerusalem for the Far East, his focus shifts from holy sites and Muslim doctrine to homunculi, giant ants, and cannibalism. Shameless in his fabulism, the Mandeville-

\footnotetext{
* This project takes MSS Royal 17 C (TEAMS ed.) and Egerton 1982 (EETS ed.) as its primary texts, two of the most intact Middle English redactions.
} 
author asks his readers for herculean feats of credulity. Yet Stephen Greenblatt has suggested that medieval readers considered The Book an authoritative source of information. Well into the sixteenth century, actual explorers like Columbus and Hakluyt referred to its account during their own imperialist endeavors. ${ }^{28}$ Without dwelling on the exact nature of this credulity, we can imagine that the text resonated more keenly with premodern readers - for whom large swatches of the map remained blank, filled in with imaginative inference. Textual variance notwithstanding, this work reached large and diverse audiences. It likely "had a position far more central than has hitherto been claimed, even by those who acknowledge how much it was read. It seems that the book was printed more often than any other English non-religious work from the Middle Ages, including Chaucer, Lydgate, and Langland." 29 Based on material evidence, it seems safe to assume a widespread acquaintance with anecdotes in the "mandevillean multitext." Only one other genre produced a compilatio to rival The Book, one equally fantastical and amoebic: hagiography. In his praise of The Book's transregional appeal, one scholar insists that "to find works that reached as many far-flung corners of Latin Christendom, one has to turn to saints' lives (in particular, the mid-thirteenth-century Legenda Aurea or Golden Legend)..."30 It is perhaps no coincidence that The Book and the Golden Legend jointly shared priority of place in the hearts and minds of medieval readers. After all, the Mandeville-author borrows heavily from other works, including the Golden Legend itself. The texts overlap, literally the same at moments. Certainly the Mandeville-author excels at folding popular, preexisting tales into an overarching narrative; readers may have derived pleasure from recognizing anecdotes from other sources. This probably had an authenticating effect, as opposed to inspiring suspicion akin to modern notions of plagiarism. Hagiography and The Book had an intertextual relationship of mutual reinforcement. Yet The Book's relationship to saints' lives proves more than citational or 
allusive. The major claim of this chapter will be that we cannot understand The Book apart from its saints, and that sanctity provides a lens through which Mandeville invites us to read the world. As a pilgrim narrative, The Book was already participating in a popular subgenre of hagiography. In his short but perspicacious study on pilgrim literature, Donald Howard suggests that, before The Book, "it remained for somebody to see the literary possibilities of the genre." 31 Pilgrim narratives constituted a "major literary genre" with about " 262 composed in the two centuries after 1320."32 Departing from the didactic and reporting ethic that animated earlier pilgrim narratives, the Mandeville-author compiled, reframed, and de-politicized some of the most compelling moments in previous travelogues. Recent criticism has considered it "a piece of prose fiction, of 'popular' literature — a romance of travel." 33 Though it required great learning to assemble The Book, the Mandeville-author constructs a proto-novelistic narrator. He neither pretends to write a guidebook nor assumes "the bookish stance of citing authorities: though he had a library of travel books before him as he wrote, he concealed it." ${ }^{34}$ Instead, he operates in the playful world of fantasy, giving his readers' imaginations freedom to meditate on his assertions in whatever way they choose.

The Book's proximity to hagiography is directly related to its speculative, fantastical ethic. The cult of the saints predates even the assemblage and canonization of the Christian Bible. Indeed, early Christians' veneration of martyred bodies helped produce the Incarnational theology developed during the great councils. As with any folkloric tradition, to some degree cultic devotion (and its attendant stories) is the doctrine of the people. Because these popular wisdoms and fancies assume the form of narrative, the discomfort and enjoyment they produce are almost indistinguishable. Heterodox thought and speculative theology are difficult to pinpoint when they come in the form of a dragon. ${ }^{35}$ This blending of obvious untruths, exotic marvels, 
and traditional miracles engenders a special mode of incredulity — one in which aesthetic delight and religious belief are charged with something like hope. The "page and the reader's imagination effect an alchemy" creating an impression more saturated and fantastic than firsthand experience could produce. ${ }^{36}$ Stories designed for mass consumption, indiscriminately beloved by people from all tiers of society, often give voice to the otherwise inarticulable desires and impulses of a culture. Both The Book and the Golden Legend blur the boundaries between fantasy and history, the stuff of legend.

A side-effect of this generic fabulism is the radical opening-up of Christian sanctity. Both texts take the sacred as experienced and enacted by human persons for their subject matter. By gleefully occupying the popular and magical territory between doctrine and romance, both The Book and the Golden Legend render the holy in spectacular, unexpected, and often bizarre terms. Their rollicking claims to authority (from the faux-etymologies in the Golden Legend to Sir John's statement that the pope has ratified his account) liberate them from authoritative scrutiny, so tongue-in-cheek are they. When the Catholic church's campaign against heresy and vernacular translations of scripture was at its peak, hagiography and travelogue flourished in numerous languages. ${ }^{37}$

Because he understands travel as pilgrimage, travel-writing is hagiography for the Mandeville-author. This assertion is not merely theoretical, but is born out in a rough statistical examination of The Book's content. Some versions of The Book contain mention of as many as fifty named saints. If we include references to the Hebrew patriarchs, virtuous pagans, and mythical heroes, the holy head-count more than doubles. The concept of sanctity rules the text, and the word "saint" occurs even more frequently than mentions of concrete persons. The Mandeville-author leans heavily on this designator. Considering the pervasiveness of 
hagiographical themes, tropes, and topoi in The Book, it becomes clear that the theorization of sanctity is one of its primary concerns. Due both to the complexity of the manuscript tradition and the dizzying panorama of wonders, we tend to read over, around, and through the narrative's most recurring character: the holy exemplar, the sanctus.

Jerusalem-bound, Sir John of Mandeville casts himself as a pilgrim first and foremost. ${ }^{38}$ Every Christian pilgrimage has as its telos a person of virtuosic sanctity. The pilgrim seeks holy things, which are often marvelous as well. Yet going beyond the explicit borders of Christian sanctity, Sir John encounters marvels and wonders about their holiness. The question "What is holiness?" drives the entire narrative. This places The Book in a long genealogy of hagiographical travel-writing. Late antique pilgrimages to biblical holy sites almost always involved visits to living holy persons. The rise of asceticism made the prophetic past visible in the spectacular lives of the desert fathers and mothers. Pilgrims to Egypt often prepared for their trip by reading saints' lives. Conversely, geography was "the organizing principle" of the earliest vitae of the desert fathers. ${ }^{39}$ Pilgrimage to Jewish and Christian sites routinely involved visiting the holy persons whose lives showed forth a direct continuity with biblical times. The process of going on pilgrimage (or of reading about one) sanctified the pilgrim-reader in turn. Jerome's account of Paula's pilgrimage to the Holy Land contains long asides about the woman's sanctity, turning "the pilgrimage account into a hagiography." 40 Since its earliest days, the project of Christian travel-writing has been to provide a vicarious experience of saintly spectating to its readers.

Paradise Deferred: Apophasis and Travel-Writing in The Book

The Book's itinerative structure participates in and reflects its poetics of apophasis. The unknowing of travel intersects with the inscrutability of the holy. Almost by definition, travel- 
writing purports to make the unknown known. The traveler produces a linguistic rendering of his own experiences, in which the reader can vicariously share. He reveals the world, if only virtually. This mandate assumes an added layer of drama when the protagonist has ventured into new spaces_-new, that is, to him and to readers "back home." As he discovers the world to himself and the reader, the blank spaces on his map shrink. Or do they? The Book of John Mandeville both participates in and criticizes these conventions. In so doing, it underscores the deeper truth of all travel-writing: the more one learns, the more one learns there is to learn. Each revelation points beyond itself to new vistas of the unknown. Travel both discloses newness and gestures toward further reaches. Understanding this, the Mandeville-author re-veils as he reveals. ${ }^{41}$ The Book constantly journeys beyond the protagonist's ken, describing locales to which his path never took him and speculating about people he never met. He alludes to these unseen wonders with a dubiety that throws their very existence into question. The incredulity with which he treats hearsay would seem to authenticate his eyewitness claims, yet the narrator enshrouds even his own experiences in mystery.

The Mandeville-author delivers his story through the character of Sir John, an English pilgrim-knight who claims to recount that which he has seen and is now remembering. Making his intention plain, Sir John says in the Prologue, "Y shal divise a parti of that $\mathrm{Y}$ have seye in the worlde as hit may come to my mynde herafter." ${ }^{42}$ The narrator will represent phenomena that he has seen firsthand, as recalled by his memory. Despite the repetition of "see" throughout the Prologue, the eyewitness gaze is qualified by both its partial replication ("a parti") and its temporal remove ("herafter"). Sir John playfully admits to the incompleteness and fallibility of his eyewitness account, thus highlighting the fictionality of The Book as a whole. ${ }^{43}$ A deep irony underlies this admission: Sir John's account may well be flawed, since Sir John himself never 
existed. Not only that, but, as many critics like to say, the author himself probably never traveled beyond the nearest library. ${ }^{44}$ What is truth, then? What sort of knowledge does such mendacity afford? Rather than evade the fraught nature of its assertions, The Book confronts it head-on. It maintains a dialectic between revelation and hiddenness. The text itself functions as the horizon from which phenomena emerge, and into which they recede.

The Book's preoccupation with the unknown manifests on the level of grammar. The Mandeville-author makes extensive use of apophatic language. Apophasis involves unsaying that which has been said. Such language proceeds by way of denial, negating affirmative statements in order to highlight the incomprehensibility of the thing communicated. Cataphatic speech, on the other hand, is affirmative and referential, emphasizing the tangibility or conceptual accessibility of the thing described. At first blush, travel-writing seems like a cataphatic discourse. It seeks to represent concrete realities encountered by one journeying into the previously unknown. Yet to sally forth is to encounter new limits: the road unfurls endlessly, always ramifying. Each positive choice implies any number of negative choices, all the roads not-taken. The adverb "not" appears constantly throughout the text. It allows the Mandevilleauthor to depict marvels while simultaneously putting them under erasure.

The Mandeville-author's apophatic rhetoric occurs most frequently when he describes spectacles he has not seen-places to which he has not yet ventured. This has the effect of deferring exotic landscapes indefinitely. Sir John describes an island where Hippocrates's daughter was transformed into a hundred-foot-long dragon and now resides. He wisely qualifies the story with "as men seyn, for I have hit nought seye."45 Though the Mandeville-author will plead hearsay numerous times, he does so especially when his reportage has grown exceptionally marvelous. By introducing some doubt, he creates space for his readers to enjoy the episode on 
their own epistemological terms, sharing in his incredulity though free to realize the spectacle in their minds. ${ }^{46}$ Despite the evocative quality of these marvels, the Mandeville-author presents hearsay precisely as unseen ("nought seye"). Physical invisibility provides not only a metaphor for the unknown ("I don't see what you mean") but also an existential reality within the fiction of the narrative. Some eyewitness. Later, Sir John describes a land where only nettles will grow, saying, "as Y have herd say-for Y was never ther." ${ }^{47}$ He also introduces one of several mountains with unreachable peaks. Noah's Ark sits on Mount Ararat still, but "a man may noght wel go theder uppon that hille for snow that lith alway uppon that hille winter and somer." As a result, "ther cometh never man sithe Noe was," except for one monk who fortunately retrieved a relic. ${ }^{48}$ The Mandeville-author describes the site of a biblical event that Christians are enjoined to believe, yet offers a natural reason (a snow-capped peak) for its inaccessibility. He alludes to many such deferred landscapes.

One example is so compounded as to imply an almost infinite regress of marvels. After recounting Sir John's death-defying trip across the Vale Perilous, a demon-haunted valley from which four of his companions fail to emerge, the narrator grows a bit giddy. He states that "byyonde that valey is a gret ile wher that peple ben as gret as gyauntes." 49 The immediacy of his description ("they have no clothing but beestes skynnes") implies Sir John may have seen these giants himself. ${ }^{50} \mathrm{He}$ never asserts this, though, so the text remains ambiguous. He goes on to note that "byyonde that yle was another yle wher beth gretter gyauntz." 51 Sir John says of these larger, more remote giants, "Y sey hem noght." 52 The narrator invites his readers to imagine an unending chain of islands, peopled by larger and larger giants. The quintessential monster, the giant often stands in for the unknown, the limits of the human imagination. ${ }^{53}$ One thinks of the Nephilim of Hebraic lore, the eald enta geweorc of Anglo-Saxon poetry, or Swift's 
Brobdingnagians. These twinned islands, one dwarfing the other, evoke this hall of mirrors on their own, yet the Mandeville-author continues. "And another ile is ther wher ben wicked and lither wymmen" who, Medusa-like, kill men with their gazes. ${ }^{54}$ And still "Another ile is ther of faire peple," who fear virgins for the "eddres [adders] in her bodies." 55 One gets the sense that there will always be "another ile." Mandevillean poesis remakes the world anew, describing a world so vast and fecund that the earth's surface area could never accommodate it. The narrator ends this particular chain of marvels on an ironic and moralizing note. Continuing his refrain, he says, "Another ile is ther wher they chesen the kyng...noght for his rychess... but he that is of good condiciouns and most ryghtwys and trywest." One must journey far indeed-encountering numerous monsters on the way - to discover a truly righteous king. ${ }^{56}$ The fabulist interludes escort readers far from home so that they might return to it with a critical eye. Yet Mandevillean apophasis does not restrict itself to pointing "byyonde" to things he has not seen.

Sometimes Sir John simply withholds information from his reader, pleading his own finitude. This open-endedness actually includes the reader in a special way, inviting her to participate in the narrator's world-building. From the beginning, Sir John has acknowledged that he will only convey "a parti" of what he has seen. ${ }^{57}$ This apologia recurs throughout the text: "Many other maner of peple beth theraboute, of wham hit were to moche to telle." 58 The wonders overwhelm his attempts at storytelling. Having only so much time and space, he has to be strategic. These teasers reveal the incompletion of his narrative while leaving it unbounded. The apophatic landscapes that remain in darkness, out of sight, enrich his affirmative accountsshadows cast by visible wonders. Unseen locales charge the given, cataphatically-described landscapes with the glamour of themselves having a "byyonde." Even the hyper-marginal dogheaded men could leave to seek a newer world. ${ }^{59}$ 
The Mandeville-author concludes with an apophatic coup de grâce. He acknowledges all that must remain off-page by protesting that he will not speak of those things:

Ther beth many other contrees and mervayles which Y have noght y-seye, and therfor Y can noght speke propurly of hem. And also on contrees wher Y have y-be beth many mervailes of which Y speke noght, for hit were to longe tale. And also $\mathrm{Y}$ wole say no more of mervayles that beth ther, so that other men that wendeth theder may fynde many nywe thynges to say, of whiche $\mathrm{Y}$ have noght tolde nother y-spoke. For many man hath gret likyng and desire to hyre nywe thynges. ${ }^{60}$

Sir John's experience of unknowing bears directly upon what sorts of linguistic proclamations he can make. He finds his "speech" (i.e., writing metaphorized as oral tale-telling) severely hampered: "Y can noght speke propurly," "Y speke noght," "Y wole say no more" "Y have noght tolde nother y-spoke.” All of these denials constitute an act of unsaying. Yet, paradoxically, he must mention the "other contrees and mervayles," "many mervailes," "more... mervayles," "nywe thynges," and more "nywe thynges" in order to apologize for not mentioning them. This rhetorical trope, known as occupatio, is one form of apophatic speech.

Not only can Sir John "noght speke," he cannot speak "propurly.” What would proper speech entail? The narrator does not seem to consider his apophatic unsaying — his negative speech — to be "proper." He fantasizes about a cataphatic and affirmative mode of description in which he might engage if he only had more knowledge. Sir John offers the excuse that his travels have not been comprehensive ("many other contrees and mervayles which Y have noght yseye"). This seems reasonable: one cannot speak of what one does not know. Yet Sir John reports hearsay constantly. Have the non-eyewitness anecdotes consisted of improper speech? Perhaps Sir John alludes to marvels about which he has heard nothing beyond the fact of their existence —or perhaps not even that. If these allusions have no specific referent, then how does he know "other... mervayles" are out there at all? This requires a kind of faith or hope. Sir John 
suffers from temporal as well as geo-spatial finitude. He lacks both the time and patience to recount even the wonders he has seen. Of some he will not speak, whether properly or improperly. Sir John cheekily asserts, "Y wole say no more" because "hit were to longe tale." Unseen wonders aside, it would take too long to convey even those he has witnessed. His tale would grow unwieldy, "to longe." This statement pricks at the reader's curiosity. Narrative gaps serve as entry-points into the text, spaces that the reader can fill with whatever most delights her. Sir John refuses to perform exegesis on his own text, leaving wonders for others to find and recount.

This whimsical gesture has a New Testament antecedent. Sir John's apology echoes the famous concluding lines of his evangelistic namesake: "But there are also many other things which Jesus did; which, if they were written every one, the world itself, I think, would not be able to contain the books that should be written" (John 21.25). This instance of scriptural occupatio opens up the most canonical of Christian narratives. A vast apocryphal tradition attests to its effectiveness in generating creative interventions into the vita Christi. Perhaps this biblical example of apophatic speech inspired the Mandeville-author's narratival ethic.

The Book's most significant deferred locale reflects the text's concern with the sacred. Sir John identifies as a pilgrim, which charges his sight-seeing with spiritual significance. ${ }^{61}$ He seeks nothing less than heaven on earth. The quintessential deferred landscape is, of course, Eden. Sir John longs to get back to the Garden, but it resides at an infinite remove from humankind. Chagrined, Sir John voices one of the great understatements of medieval literature: "Of Paradyse can I nat speke propirly for I have nat be there, and that angoreth me."62 Only Eden's remoteness elicits an emotional response from Sir John. Anger tinges his unknowing, as if paradise should 
rightfully belong to him. No place engenders comparable desire, yet the terrestrial paradise remains physically unreachable.

The Mandeville-author surrounds Eden with a fantastic topography, encoding apophatic denial into the landscape. The geography manifests and overdetermines its unattainability. Paradise is "the hyghest londe of the worlde... so high that it toucheth nere to the sercle of the mone." Not even the Flood reached this place. ${ }^{63}$ This mountaintop motif recurs throughout the text, but here it reaches hyperbolic heights. Eden's mountain has cosmic proportions; its peak almost brushes the moon. The Mandeville-author makes paradise as unearthly as possible while maintaining its physical reality. Other obstacles block the way. Eden "is enclosed all aboute with a walle," a structure designed to keep others out. Walls endow landscapes with a negative grammar, insisting that certain agents will "not" pass. Additionally, the wall itself is hidden from sight, camouflaged by a thick blanket of moss, so that "men may se no stone ne nothynge ellis wherof it is. ${ }^{964}$ Again, apophatic speech grows paradoxical. If no one can see the wall, how can anyone assert its existence? Even the barrier shares in Eden's inaccessibility; ironically, this obviates its function, making it purely symbolic. Should a wanderer reach the general vicinity of paradise, she would not be able to discern its boundaries, much less its entrance. This hiddenness poses the least of her problems, though, as other obstacles will prevent her from getting that close. Four unnavigable rivers both lead to paradise and cut it off from the rest of the world. Four actual rivers (the Ganges, Nile, Tigris, and Euphrates) assume extraordinary, inhibiting qualities the closer they get to paradise. Typical of the Mandeville-author's marvels, the rivers possess super-natural qualities in the truest sense of supernatural. Their natural features are exaggerated to an impossible degree, revealing the marvels inherent in the natural world while gesturing toward the invisible reality suffusing it. "Ne by those ryvers may no man passe," for their waves 
wax too great. ${ }^{65}$ Their fury exhausts, blinds, and deafens those who try them. ${ }^{66}$ In case any doubt remains, Sir John puts it bluntly, and in two different ways: "no man lyvynge may go unto that Paradyse" and "no man may passe there but thorough special grace of God." 67 The former forecloses on any possibility of visiting this marvelous, if physical, landscape. Yet the second introduces the possibility that God's favor might grant passage to select souls. This raises the question of sanctity.

The material realities of Sir John's journey have metaphysical implications. It takes a special kind of grace to reach paradise. Sir John asserts the same thing about the Vale Perilous, another liminal, spiritualized place. The Vale contains "an entré to Helle," and those who traverse it risk "beth anoon astrangled with fendes." Only "a good Cristen man that is stable in his faith" can pass over unharmed. ${ }^{68}$ The fact that Sir John manages to do so theoretically confirms his sanctity. Greenblatt says of the protagonist, "The agents of mobility had found their secular saint." 69 According to the text's own logic, we could drop the modifier "secular" and still be correct. Eden evokes and presages the heavenly paradise, connecting humanity's telos to its origins. Perhaps earthly pilgrimage cannot culminate in Eden, but it can and should lead one to heaven. This seems to be the metaphoric implication and theological assertion behind the Mandeville-author's account of paradise. When we see God face-to-face, then will we be able to speak properly, as logoi cede to Logos. His final lines, part benediction, part prayer-request, clarify this. He hopes his readers will share in "my good pilgrimage and other good dedes that Y have do and $y$-wrought and do sithe to my lifis eynde."70 Equating his pilgrimage with his life's good works, he asks for God's grace and hopes God will bring everyone "to His joy that ever shall last." ${ }^{71}$ For the Mandeville-author, the hope of heaven motivates all other journeys. 


\section{Mandeville's Hagio-Navigation and its Receding Holy}

Sir John navigates by the saints, describing places in terms of holy association.

Everywhere he goes, he sees them. The variation with which they appear makes it difficult to categorize or classify their appearances. Sir John's most straightforward encounters involve the shrines of recognized Christian saints. Their relics seem to provide a concrete, sacramental mode of presence, though the Mandeville-author often problematizes this givenness. Other mentions are more associative; he finds himself in a place where a living saint once stood, or where a relic used to be housed. Saints are omnipresent in the form of nominalization, lending their names to towns, bodies of water, and churches. Religious orders and communities continue to honor their founders. Occasionally, blood or other secretions from saintly bodies have colored stones and saturated soil. The press of their limbs marks the ground. As the narrative moves east, Christian saint cults show up in locales of increasing remoteness. The Mandeville-author uses them as a hinge with which to put Eastern Orthodoxy in dialogue with Western Catholicism. He points to the apostolic origins of heterodox Christians as well. Both text and pilgrim move according to a process we might call hagio-navigation. At first, this process proves fairly straightforward. Recognizable townships and landmarks have canonical associations with Christian holy people. As Sir John moves east, the saints become less recognizable in their association with nonWestern and heterodox Christians. Eventually, they leave Christianity behind altogether.

The Book of John Mandeville is an inquiry into the sanctity of the unknowable Other.

Scholars have noted that the Mandeville-author seems primarily concerned with "what people believe., ${ }^{, 2}$ From Christian folklore to Near Eastern religiosity to monstrous ritualism, the text explores the diversity of religious impulse. Some have described this narratival lens as anthropological. We should avoid ascribing neutrality to this text, however. Though the text is 
exceptional in its cultural relativism and seeming tolerance, Christianity remains the unquestioned assumption beneath its observations. One especially devastating failure stands out and must be addressed before focusing on more positive portraits of religious difference. Like many late antique and medieval thinkers, the Mandeville-author honors the Old Testament patriarchs while entertaining an invidious paranoia about his Jewish contemporaries. In other words, he chooses to include anti-Semitic anecdotes from his source texts, rather than excise or soften them as he does in other sections. Stephen Greenblatt has argued that The Book's ability to admire distant Others is radically compromised by its inability to do the same for religious difference somewhat closer to home. ${ }^{73}$ This virulent anti-Semitism disappoints a modern reader, to say the least, especially so in an otherwise comparatively open-minded text. In its best and worst features - its tribalism, its proclivity for marvels, and its fascination with sanctity - The Book resembles and participates in the hagiographical tradition.

In addition to its importance for pilgrimage, Jerusalem served as a great generator of hagiographical lore. Trips to the Holy Land centered on adoration of Christic monuments, but they also entailed veneration of the Virgin, the apostles, Mary Magdalene, and other gospel saints. Many of the sites Christians visited were "Old Testament" locations, both because these sites were obviously important to Jesus himself and because the tombs of the patriarchs and sites associated with narratives from the Hebrew Bible were interesting in their own right. ${ }^{74}$ Eastern Christians traditionally referred to these Hebraic figures as "saints," whereas Latins tended to accord them a different mode of veneration. ${ }^{75}$ Paying homage to biblical figures often bled over into veneration of more contemporary holy persons. Pilgrims to Jerusalem frequently included journeys to Egyptian shrines and monasteries in their trip. Additionally, pilgrims themselves were sometimes canonized, building up Jerusalem's saintly superstructure with their own lives. 
St Helena's supposed discovery (or "invention") of the True Cross provided a foundational example, as well as her translation of various other relics. Her pilgrimage cemented the practice's importance and centrality for Christians, consolidating imperial power in the process. ${ }^{76}$ The empress's life would itself generate a large body of hagiographical discourse, with pilgrimage assuming center stage in her vita. Inasmuch as it is a pilgrim narrative at all, then, The Book participates in a subgenre of hagiographical narrative. Yet its hagiographical qualities exceed this intrinsic connection to Holy Land pilgrimage. Its preoccupation with saints begins before Sir John leaves home and continues well past his time in Jerusalem.

At the very beginning of his narrative, Sir John uses the saints to locate himself in space and time. The references are so banal as to seem inconsequential, yet they provide the starting coordinates of the pilgrim's journey. In the first sentence the narrator locates himself in England, specifically "the toun of Seynt Albons." 77 Toward the end of the Prologue, he describes himself as "bore in Engelond in the toun of Seynt Albones and [having] passed the see in the yer of the Incarnacioun of Oure Lord Jhesu Crist 1332 uppon Seynt Michelis day." ${ }^{, 78}$ The Mandevilleauthor chooses to locate his protagonist in a town named for a foundational English martyr, St. Alban. Like many of the most celebrated Mediterranean martyrs, St. Alban was executed during the fourth-century reign of Diocletian, connecting the English periphery to the Roman center of Christendom. By naming St. Michael's day (Sep. 29), Sir John indicates that he has set out in autumn, which seems odd. Chaucer identifies pilgrimage as a springtime activity, undertaken when the weather is pleasant and living things itch for movement and diversion. Why would Sir John choose to depart during Michaelmas, in the middle of a festival? More symbolic than anything else, the date anchors his voyage to a particular holy day. These nominalizations signal different modes of cult. The city's toponymy refers to the event of martyrdom and the 
subsequent abbey that took its name from the saint. "Michaelmas" refers to a calendar day, reminding us that medieval people used the saints to measure time. ${ }^{79}$ This festival in turn memorializes an angelic apparition. The saintly names provide concrete plot detail and serve a thematic function. Patrons of space and time, they signal the metaphysical longitude and latitude by which the pilgrim navigates. Their seeming inconsequentiality reflects the banality of sainthood. Subsequent and relentless invocations of saintly figures imbue these opening mentions with significance.

Upon leaving home, Sir John finds that saints line the road to Jerusalem. The first half of The Book provides brief sketches of various routes to Jerusalem and then describes the city itself. Sir John's list of attractions consists mostly of relics, shrines, churches, and biblical sites. We might think of the Mandeville-author's manner of hagiography as topographical invocation. Sometimes the Mandeville-author provides names in passing; sometimes he describes the moment when that saint's vita intersects with the path he delineates, briefly narrating an episode from the saint's life. En route to Jerusalem, for example, one might visit the church "of Seynt Sophie," the Hagia Sophia. ${ }^{80}$ The potentially titular quality of "holy" caused visitors to associate the basilica with St. Sophia, a second-century woman martyred with her children Faith, Hope, and Charity. Like many early saints' lives, this symbolic story is likely fictitious and itself alludes to the same concept of Second Person as Holy Wisdom for which the church was actually named. This conflation of saint, symbol, and church illustrates the mutually refractory relationship of texts and lives, a cultic hall of mirrors in which legends were continuously born and reborn. Constantinople also houses "Seynt Anne Our Lady Moder," "the body of John Crisostom," and "Seynt Luke the Evangelist." These and "many other relikes beth ther" for anyone who desires to see them. ${ }^{81}$ Shipping out from Constantinople, one will likely navigate the 
“Brace de Seynt Gorge." 82 The Hellespont (or Dardanelles) does have an arm-like shape, and St. George was martyred in modern-day Turkey in the early fourth century. On the way from Constantinople to Jerusalem, one might pass Pateran, "wher Seynt Nicholas was bore." 83 Anyone who sails by Colossae should note that "Seynt Poule in his pistle wrot to the men of that ile." ${ }^{84}$ In Cyprus is a monastery that houses "the cros of Dismas the good theef" who is venerated as a saint. There one might also visit "the body of Seynt Hillari," noting that "Seynt Bernard [was] ibore" nearby. ${ }^{85}$ In Shefa 'Amr (which the Mandeville-author calls "Caffere") "Seynt Jame and Seynt John [were] ybore." ${ }^{86}$ In Egypt is "a fair cherche of Our Lady wher she dwellid 7 yer when she was out of the lond of Jude... And their lith the body of Seynt Barbara the virgin." ${ }^{\text {"87 }}$ As this brief spread of examples indicates, Sir John highlights saintly sites indiscriminately. He includes figures coincident with and adjacent to the life of Christ: his mother, his grandmother, Dismas, disciples, evangelists, and Paul, who became an apostle after Jesus's death due to a visionary experience. Some of these figures are historically attested; others exist solely within the realm of legend and tradition. Sir John also topographically invokes theologians and bishops from the fourth century to the twelfth. He mentions late antique martyrs as well, such as Barbara and George. The list varies in both saintly type and saintly association. Some mentions involve secondary relics (the cross of Dismas); some, actual bodies (and, by extension, their attendant shrines, churches, liturgies, and local cultic devotions). Some are birthplaces, and some served as temporary shelter. Again, some of these events are certain historical facts (the birth of St. Bernard); others occupy a more legendary space (the Flight to Egypt). The Arm of St. George is a geographical feature anthropomorphized through its association with a life lived near its shores. In this case, the saint has merged with the landscape, literally used to map the land. These sites of cultic activity and association proclaim the movements of holy persons through space, 
occasionally collapsing the lives into the landmarks. They would seem to insist on the saints' lingering presence.

In fact, the shadow of saintly absence haunts most of these sites, even the relic-bearing ones. The text's apophatic epistemology, a structural feature of itinerative discourse, works in conjunction with the apophatic quality of holiness. The Book constitutes a textual site where the unknowing of travelogue and the unknowing of holiness intersect. The experiences of sainthood that Sir John offers often involve empty tombs, imprinted stones, hidden marvels, and missing relics. The phenomenon of translatio, or movement of a relic from one place to another, accounts for some of this. One might consider this a process of despoiling or furta sacra, especially with regard to Jerusalem. ${ }^{88}$ As mentioned, St. Helena's trip both consolidated imperial power and helped legitimize the popular but theologically questionable practice of pilgrimage to Jerusalem. It also resulted in the discovery of several key relics. One reason a visitor to Constantinople can visit the body of St. Anne is that "Seynt Eline brought hure ther fro Jerusalem." ${ }^{89}$ Later, Sir John repeats this fact, using the legitimizing word "translate." $" 90$ It would be easy to consider this translation a kind of theft — the dubious authenticity of such discoveries notwithstanding — and Eastern Christians would consider similar translations after the sack of Constantinople (1204) in that manner. Of course, St. Helena also discovered the True Cross, which had supposedly been "i-hudde in the erthe under the roch of the mount of Calvarie." ${ }^{91}$ Hiddenness characterized this relic of relics, at least initially. Sir John admits to the indeterminacy of even Christic relics. The crown of thorns, for example, can be seen in both Paris and Constantinople, throwing both into question. $^{92}$

Not all empty shrines have a human translator-thief to blame. The Mandeville-author says St. John the Evangelist made it to Ephesus before he died, and there one might find the 
saint's tomb, over which a church has been built. Yet "in the tumbe of Seynt John is nothyng elles but manna, for his body was translatid into Paradis." 93 Having slept "uppon Our Lordes kne," St. John saw "many prevy thynges of hevene."94 Perhaps the "disciple whom Jesus loved" harbored too many heavenly secrets to remain outside of heaven. God himself has removed St. John's body to heaven, having done something similar for the Virgin. A pilgrim might visit the Church of the Assumption, but not the body that bore Christ. The Mandeville-author uses translation to describe movement into the terrestrial paradise as well as the heavenly one. He mentions that some think God made Adam in Damascus then "translatyd [him] into Paradis," upon which arrival he was almost immediately driven back out. ${ }^{95}$ The ever-deferred Eden, in which it seems impossible to dwell, is here analogous to heaven-a final, hoped-for destination, but one that cannot be seen until the darkest of journeys is undertaken. Saints are often translated out of sight, dislocated from their places of death and rendered inaccessible.

The Mandeville-author provides an exemplary instance of deferred sainthood in his description of St. Catherine's monastery on Sinai. This passage is missing from most of the major redactions, surviving in the Egerton manuscript. For this reason, scholars refer to it as the "Egypt gap." "Gap" is a felicitous descriptor for this narrative about the site that emblematizes unknowing within the Judeo-Christian imagination: Mount Sinai. "pat place es called pe schadow of Godd." 96 Drawing on the ascent of Moses narrated in Exodus, Pseudo-Dionysius uses the mountain as a figure for God's mystery. Similar works, such as the fourteenth-century Cloude of Unknowyng, do the same. The Catherine episode deserves its place in this genealogy of vernacular apophatic religious writing. The Mandeville-author's aesthetic of the marvelous and his fictional frame narrative make it easy to overlook the passage's apophatic qualities. Its generic difference (from a contemplative treatise) obscures its theological resemblance, for here 
travel-writing, hagiography, and negative theology intersect. The Egypt gap illustrates Mount Sinai's obscurantist effects on the cult of St. Catherine. It provides an explicit example of hagiographical writing as apophatic discourse. Home now to one of the most popular late antique martyrs, Mandeville's Sinai retains its reputation as the via negativa's pinnacle. St. Catherine's monastery at Sinai continues to be an important site for Eastern Christians. A highly cataphatic miracle has driven this popularity, and reports of it began in late antiquity. Sir John reports that "commez oute a litille oile as it ware swete... [and] pai gaffe a lytille quantitee til pilgrimes."97 In addition to this miraculous oil, the monks "schewes pe relyques of pis virgin," as well as “many oper relyques," to pilgrims. ${ }^{98}$ The Mandeville-author's repetition of the verb "show" suggests that there should be much to see on Sinai. And, indeed, there is. Yet these partial glimpses highlight all that remains hidden, revealing only the tourist's version of Sinai.

Though monks display her head and distribute holy oil, the rest of Catherine's body is missing. This fact alone is not unusual, but the circumstances surrounding its disappearance overdetermine her remoteness. Angels have translated the virgin's body to yet another, more distant mountain (“anoper grete mount whare pe aungels groue pe body of sayne Kateryne"). ${ }^{99}$ Maybe. According to the saint's collect, Sir John muses, Catherine should be buried where God gave the Law. ${ }^{100}$ Her body is missing from Sinai, however, and is said to be buried within an unmarked grave on a farther, unnamed mountain: "And pare whare sayne Kateryne was grauen es na kirk ne na chapelle ne oper dwelling place, bot per es a hepe of stanes."101 The collect must be either wrong or poorly worded, Sir John concludes, chagrined. Otherwise two places ("twa steeds") share one name ("beres bathe a name"), further confusing the matter. ${ }^{102}$ An aura of supernatural mystery surrounds the relics of St. Catherine. Nothing but a mysterious cairn remains to identify the great philosopher-martyr, and that lies on an uncertain spot on a mountain 
of dubious identity. The use of "y-grave" to describe her body lends it a carved or engraved sense, even as it refers to the pit into which it is lowered. This apophatic unsaying of a saint's body, which the Mandeville-author presents only to obscure, implicates the landscape. A mountaintop more remote than Sinai? This out-negates the central landmark of negative theology. The second mountain provides yet another example of the Mandeville-author's penchant for landscapes just beyond the actual and epistemological horizon. The mystery of the holy (angelic burial in a hidden grave) blends with the remove of distant locales (which mountain?) - a geographical apophasis. The Mandeville-author ties this cultic confusion into the mountain's history as a place of hiddenness. He points out that "na man wate whare he [Moses] was grauen." 103 Moses's body remains lost as well. The only relic one might see of the holy patriarch is "pe fourme [or 'impression'] of his body" left in the rock face when God commanded him to hide, "so fast he thrast his body perto."104 As proof of Moses's (non-)vision of God, one can view the hollow space carved out by his fearful flight from divine presence, a holy concavity.

To compound the secrecy of St. Catherine's cult further, the monks themselves prove hesitant to share information. Sir John has heard reports that when a prelate of this monastery dies, a miraculous scroll appears on the altar, revealing the name of the next prelate. He "asked pe mounkes if it ware so, bot pai wald nozt say." When pressed, they admit that "sumtyme it felle swa." This secrecy rankles Sir John, who considers it his mission to report marvels to the world. He reproves the monks, arguing that their duty regarding "Goddes myracle and his grace" is "to publisch it and schew it... to excit men til deuocioun." 105 This partial-saying of marvelous events reminds readers of Sir John's promise to tell only "in part.” Religious mysteries involve as much discretion as disclosure, the cult of the saints being no exception. The monks guard as 
much as they reveal, identifying certain miracles as unspeakable. Here, Sir John seems to articulate the Mandeville-author's literary ethic. His project has imperative force. He recounts these marvels in order to "excite men to devotion." His role as a marvel-monger has a pastoral component. ${ }^{106}$ As The Book repeatedly indicates, an aesthetic of the marvelous cannot be a straightforwardly cataphatic one. Mysteries have to be revealed as mysteries. His narrative must reflect the deferral of their complete disclosure.

The Mandeville-author's description of the Holy Land brings this sense of a deferred holiness to its greatest pitch. If holiness can be located and touched anywhere, surely it is in Jerusalem? Yet at the center of the text—and the medieval center of the world-pilgrims discover along with Mary Magdalene that "He is not here" (Matt. 28.6). At first blush, the sacred seems utterly immanent. Holy stones and tombs and churches abound. Mandeville imbues tangible markers with sacral significance, suggesting that there, at least, the rocks will cry out. The ground seems saturated with divine presence. ${ }^{107}$ A closer examination belies this instinct, exposing the medieval center of the world as itself centerless. At the start of his book, Sir John insists that the Holy Land surpasses all earthly places in dignity because it "is y-blessed and yhalwed" by the blood of Christ. ${ }^{108}$ Indeed, Christ's death has hallowed this land. "Hallowed" in The Book has both a homophonic and a conceptual relationship to "hollowed." Christ's holy presence has carved itself into Jerusalem, forcing pilgrims to mark his absence. Each of the holy sites or objects mentioned manifests in the mode of empty space—-such as the Sepulcher, the Ark, wells, and imprints left in the ground by holy bodies. Paralleling the impenetrability of lands on the brink of Mandeville's world, the center itself offers no direct conduit to the holy. Like nesting dolls, it contains a void or series of voids. 
As with Sinai, Jerusalem contains only contours of the divine. Pilgrims find it necessary to focus attention on the shells that form themselves around the empty space standing in for God. Most of its sacred sites have one thing in common: hollowness. God continues to hide himself, even where he revealed himself. (Not unlike his fraught Resurrection apparitions; St. Thomas has to place his hand inside Christ's wound before recognizing him, paradoxically displacing his divine flesh at the point of most intense intimacy.) The Holy Sepulcher offers the most obvious example, a site rendered extraordinary for its deliberately vacated nature. This "holy grave" is located outside the city, though walls have been built to contain it. ${ }^{109}$ Sir John tells us that "the sepulcre was alle opne, that men myghte kysse hit and touché hit," but the Sultan has since walled it off. ${ }^{110}$ Why? Overly zealous pilgrims have tried to carve into the tomb, engraving the walls so that they might take pieces of stone home with them. This tomb, holy because Jesus was once holed up in it, is now empty, carven into, and walled off. It is in danger of being further hollowed out by those who have come to see it, who, like modern-day tourists, must have their cataphatic souvenirs - concretizations of a too-elusive experience. The Temple itself is equally inaccessible. As with the Sepulcher, its immense holiness necessitates a certain removal from the crowds. Beside the Temple is a rock on which the Ark itself once stood. The Ark has long since disappeared, however, having been taken by Titus to Rome and never heard of again. Let us not forget that the Ark itself is a hollow container, rendered metonymically holy by the Law it once contained. Sir John also provides a catalogue of tombs, hollow structures made holy by the bodies they contain. Finally, the rocks themselves - hard material objects that Christ threatened the Pharisees would sing out should his human followers be silenced - the stones of Jerusalem also derive their holiness from displacement, from the empty spaces they contain. 
Sir John describes a rock on which Jesus set himself when people threatened to stone him. The rock "cleff in two, and in that clyft He hydde Hym." form of Moses imprinted onto the rock of Sinai. Whereas the latter was formed by the patriarch's attempt to hide from God, the former testifies to the God-man's attempt to flee the human mob. As with the rock on Sinai, pilgrims can view a stone structure preserving the contours of holiness. Presented to their view, then, is a structure marked by divinity's attempt to hide itself. Even Christ, the Second Person come to dwell with humankind, actively hides from human eyes. To view that hiding-place, one need only contemplate the negative space created when the rock obediently cleft itself in two. Even the Incarnational reality bears an intensely apophatic aspect. Mandeville also lists several places where a holy body part has left an impression in the ground - such as Christ's handprints at Gethsemane and a spot on the Mount of Olives where "yit semeth ther the stappes of Hys lyft foot in the stoon" from when he mounted up to heaven. ${ }^{112}$ Many other examples exist. We could point to the holy wells as sites of sacred hollowness. ${ }^{113}$ The same goes for a pit in the ground, marking the pillar against which Christ was scourged. ${ }^{114}$ Similarly, one can also see a white and red stone where "the Cros as y-sette in a morteyse."115 Again, one might not find much to see in the slotted space that constitutes the mortice itself, but the stone evokes another stone mentioned elsewhere. One might also visit the chapel by Mount Zion to see "that greet ston... which that covereth the sepulcre when Crist was leyd therynne."116 The stone obstructing Jesus from view, then removed to reveal his absence, is also on display. True, everything in Jerusalem bears holy connotations, directing the pilgrim's attention to God, but, ironically, God's absence-presence as mediated by empty space proves the most sacred relic of all. What else can a pilgrim expect? He is not here. Readers of The Book and pilgrims to Jerusalem experience the holiness of the Holy Land as hollowness. This pilgrim 
narrative does not allow its readers to rest in Jerusalem, sated by a surfeit of cataphatically-given holiness. They must see without seeing. The intrinsic elusiveness of the holy, its resistance to reification, primes readers for the strange sanctities residing on the margins.

\section{Sainthood Estranged: Recognizing Unfamiliar Sanctities}

Sainthood provides a lens through which to view religious difference. A lens, of course, is transparent; one doesn't see much when one looks at a lens. Yet look through it and all is

clarified. Though transparent, it brings other phenomena into focus. One might recognize a saint without having to articulate what constitutes her sanctity. In his phenomenology of the holy, Rudolph Otto describes holiness as an "absolutely primary and elementary datum, while it admits of being discussed, it cannot be strictly defined." 117 The saint serves as a locus for unfamiliar religious praxes, or familiar praxes made strange. She exposes the unfamiliar stranger as the defamiliarized neighbor. The Mandeville-author offers the saint as the condition of possibility for readerly empathy with alternate religiosity. Sir John looks on as people with different sensibilities, histories, values, and beliefs repurpose "his" saints and even create their own. The shared nature of the saint—-her semantic promiscuity—diffuses her nativity. The Other's devotion to the saint, or his own proper saintliness, renders him more neighborly, simultaneously imbuing sainthood with an alien quality. This brings the holiness of various nonCatholic, non-Christian, and non-human beings into view. Their metaphysical beliefs, ethical systems, and religious practices are at least partially legitimized by their resemblance to aspects of Latin cultic devotion. This same process renders the western cult of the saints strange, challenging Latin Christians' cultural ownership of both canonized saints and sanctity as such. Like a bridge, sainthood links western Christianity with its religious Others even as it articulates the measure of that difference. While the cultural phenomenon of sainthood might be 
recognizable, identifiable, and familiar, the essential reality of sainthood—sanctity_-proves more elusive. The festival whirlwind of cultic devotion has the saint's sanctity as its placid vortex. Alexander Irwin describes saints as harbors of the impossible; the saint "is a 'sliding' positionality of resistance to the normalizing effects of dominant social value systems."118 Aviad Kleinberg notes the ways in which they hold contradictory things in tension, paradoxically reconciling opposites without collapsing them. For him, saints "are amphibian creatures."119 Ambiguity becomes a space of possibility.

Holiness can be found where one wouldn't think to look. It can be sought as well as happened upon. Expanding upon his doctrine of the "anonymous Christian," Karl Rahner says something like this about the saint. He asserts that "the invocation of an 'official' saint... is always the invocation of all the saints," including those we do not recognize - those that remain invisible. ${ }^{120}$ Most of the holy dead remain mute and inglorious. Sainthood is universal, banal. Cultic devotion only recognizes, memorializes, and spectacularizes a chosen few. The banality of sanctity has an analogue in contemporary phenomenology. Marion's "saturated phenomenon" elicited protests by philosophers who questioned how frequently saturated phenomena were likely to occur. Marion responded in a chapter of The Visible and the Revealed entitled "The Banality of Saturation." ${ }^{121}$ He argues that such counter-experiences (of which sanctity is one) can occur anywhere, at any time, and that they are often subtle. This is pertinent for our study because his essay on sainthood brings these disparate features together in the person of the saint. Marion has argued that the saint must remain formally invisible. ${ }^{122}$ Indeed, sanctity in The Book is often mediated by disconcerting cultural differences.

As Sir John travels east, the "practice of Christianity becomes steadily more exotic."123 The first gradient of difference with which he must contend is that separating Latin Catholicism 
from Greek Orthodoxy. The task of reaching across the Great Schism by means of the saints seems promising. Early martyrs and confessors sustained the largest cults, and most lived before East and West severed ties. For the Mandeville-author, their lives provide a ready-to-hand shared history. Sir John acknowledges "the diversité that is bytwixt our faith and heres," but moves immediately to common ground. ${ }^{124}$ Specifically, The Book uses the thought of holy persons to reconcile theological divisions between Orthodoxy and Catholicism. The Mandeville-author cites patristic thinkers in order to bolster the Orthodox position on confession. In so doing, he employs a scholastic methodology. This makes sense, since his use of primarily Dominican and Franciscan sources suggests the author was himself a friar. He exploits the liberating potential of scholastic quaestio, fully articulating the counter-point of a given question. Instead of pivoting on the sed contra toward an authoritative, orthodox conclusion, The Book refuses to foreclose on either possibility. Rather than construct a tradition-backed case for the orthodoxy of Western theology, the Mandeville-author uses the Fathers to blur the boundaries between East and West. The rhetoric of sanctity enables this reconciliatory move. He turns to saintly theologians whom, to some extent, both traditions share, drawing on their authority in support of both viewpoints.

Sir John rehearses and affirms the Orthodox case against auricular confession-a risky thought experiment. The Mandeville-author explains that Orthodox Christians believe a sinner can efficaciously confess to God without the mediation of a priest. On his own initiative, the narrator invokes three profoundly influential theologians to indicate how they might be read otherwise than western Catholics read them. He notes that "Seynt Austyn and Seynt Gregore seyth thus:... 'Who that knoweth his synne and is y-turned, he may hope to heve forgefnesse." "125 Augustine and Gregory seem to imply that internal acknowledgement of one's sins achieves forgiveness. It is interesting that Sir John refers to Augustine, since his work has 
tended to produce disagreement between Eastern and Western Christians. Sir John then cites St. Hilary, cuing readers to his source material: "Hillary seith thus:... Synnes that ben of long tyme shal pershe in twynclyng of an eye, if the despisying of hem be y-bore of a mannes herte."126 The "twynclyng of an eye" idiom suggests that repentance effects its own, immediate absolution. The Mandeville-author surrounds an alternate teaching with a cloud of witnesses testifying to its reasonability. He deliberately refers to Augustine and Gregory as "Seynt" as opposed to "master," "doctor," or some other pedagogical term. For the Mandeville-author, the authority of these theologians stems from their holiness. This charitable use of scholastic citation makes The Book a remarkable instance of Dominican skill being applied in defense of, rather than in combat with, heterodox thought - a striking moment in intellectual history. This interpolation gives the Constantinople episode a more accommodating tone than exists in its source-text, William of Boldensele's Book of Certain Regions Beyond the Mediterranean. ${ }^{127}$ Having opened the gate to one heterodox teaching, others inevitably rush in.

The Mandeville-author goes on to describe Christians with extremely remote customs and doctrines, implying that saints bridge the gap across radically divergent Christianities. ${ }^{128}$ Sir John alludes twice to an order of "freres" called the "Georgens, for Seynt George funded hem." ${ }^{129}$ Later he adds that "St. George converted" them, claiming that these friars "doth more worship to seyntes of Hevene than other men doth." 130 The "Georgians" exceed Western Christians in their devotion to the saints, doing them more "worship." It seems at first like this group enjoys the patronage of the universally venerated Saint George, the Roman soldier martyred in fourth-century Palestine. St. George would eventually symbolize England itself, surviving the Reformation and reappearing as Spenser's Redcrosse Knight. The Book alludes to this canonical St. George in several places. Readers would probably have assumed this cult 
belonged to the celebrated martyr. The Mandeville-author seems happy to let this interpretation prevail, however erroneous. The order's appellation actually refers to the fourth-century heresiarch Bishop George of Cappadocia, whom Arian Christians venerated as a martyr. ${ }^{131}$ That heretics might have their martyrs suggests the possibility of an alternate, parallel Christendom. Whether the Mandeville-author knew this or not, the text occludes any trace of the order's heretical bent, focusing instead on its devotional zeal. Somehow, the interpersonal relationship between patron and devotee matters more than abstract, propositional belief statements. Saints provide the common ground upon which mutual respect and understanding might be built. The Mandeville-author exclaims over the "many wonderfull kyndes" of Christians. ${ }^{132}$ Religious difference becomes another species of marvel, eliciting more wonder than fear.

Sometimes a saint's legitimizing function derives from his role as apostolic founder. According to an apocryphal tradition, the apostles traveled far and wide - from Gaul to Indiaeffecting mass conversions. Their exploits provide an origin story for the dissemination of the Christian faith. In truth, the communities that claimed apostolic origin varied in theology and ritual. Nestorian Christians, for example, claimed St. Thomas as founder. Nestorianism denied the hypostatic union, severing Christ's human and divine natures. The Syriac-speaking Jacobite Christians claimed an apostolic founder as well: "Seynt Jame converted" them. Sir John brazenly adds that "Seynt John Baptist baptized them," placing their sect solidly within the gospel mythos. ${ }^{133}$ Western Christians needed reminders of the cultural and geographical proximity of "remote" Christianities to the saints nearest Christ. If Europeans failed to respect easterners' shared (and often prior) claims to saintly patronage, they risked detaching themselves from Christianity's origins. When forging these ties, the Mandeville-author prefers the designator "seynt." 
In the Mandevillean East, cultic devotion assumes a hyperrealism, manifesting in intense and saturated hues. Such excesses reveal the exorbitance of basic Western beliefs, such as the sacrality of relics. They make the familiar strange. Sir John tells readers that on the coast of India "lyth Seynt Thomas in flesh in a fair tumbe." 134 The shrine has the grotesque appeal of a roadside attraction, as the hand that Thomas put in Christ's side remains on display outside of the tomb. The hand casts away unjust petitions, drawing pilgrims who seek legal restitution. This bizarre miracle, an animate, law-giving hand, fits seamlessly into Sir John's program of "marvelmongering." Theoretically, all relics contain power, but, in the east, relics manifest this power in exaggerated ways. When actualized so vividly, this theological precept becomes startling. Reading The Book, western Christians might fantasize about animate relics that lay conveniently out of sight. Such legends jolted devotees into a renewed wonder over their own apparently inert relics. The saints are alive and active, the Mandeville-author seems to suggest, but this only becomes apparent at Christendom's ever-receding horizon.

The cult of St. Thomas also holds a mirror up to the Christian valorization of asceticism. Like all medieval specula, this one warps the original image, revealing its potential for distortion without adding anything that is not already there. Devotees process around town transporting a "greet ymage" or "simulacrum" in "a chayre." This festive tableau immediately spills over into unsettling excesses:

And som of tho that cometh in pylgrimage bereth sharp knyves in her hondes, and as they goth by the way they kytte her owen shankes and her thyes, that the blood may com out for the love of that ymage. And thay sey that he is holy that wole deye for his goddes sake. ... som falle adoun byfore that chare [a wagon bearing the image] and lete the wheles go over hem, and so they beth dede, and som have ther her armes and sholdres to-broke. ${ }^{135}$

Such dramatic self-mutilation seems so far removed from Latin Christianity as to be innocuous. Yet this episode uncovers beliefs that orthodox Christianity may imply. The ritual cutting ("they 
kytte her owen shankes and her thyes") resembles various forms of ascetic self-harm, such as flagellation, burning, wearing chains, and self-starvation. This episode reminds readers that Christianity glorifies suffering flesh. ${ }^{136}$ The spectacle may criticize the logic of Christian asceticism as advocating a body-denying ethic. On the other hand, perhaps Christian asceticism stops short of true transcendence. During the Tang Dynasty (618-907 AD), Buddhist saints are said to have occasionally burst into flames. Spontaneous combustion ignited by an otherworldly degree of holiness, this "auto-cremation" freed the saint from the world. ${ }^{137}$ Seppuku, or selfdisembowelment, afforded Japanese samurai an honorable means of escaping imprisonment and torture. Contemporary to the rise of chivalry, seppuku has no medieval European equivalent. ${ }^{138}$ Sati, the ancient Indian mourning rite, provides another example of complete rejection of the world. Yet medieval readers would not have had to look so far east for examples of noble suicide. Greek and Roman figures like Socrates, Cato, and Seneca attained quasi-saintly status for preferring death — even self-inflicted death — to disgrace.

The pagan ethic of noble suicide sat adjacent to the martyr's enthusiastic embrace of death, especially as depicted by hagiographical writing. The viragos of Prudentius's Liber Peristephanon (fourth c.) rush into death's arms. St. Agnes, for example, gives her executioner an erotic welcome. Upon seeing his "naked sword" (mucrone nudo), Agnes exclaims, "This lover, this one at last, I confess it, pleases me. I shall meet his eager steps halfway and not put off his hot desires." 139 Tertullian (second-third c.) exhorts Christians to expect and welcome untimely deaths, inviting them to imagine the tortures that their persecutors will suffer in the afterlife. St. Perpetua (second-third c.) directs the gladiator's unsteady blade toward her throat. Ignatius of Antioch (first-second c.) fantasizes that the beasts will consume his body so thoroughly, no trace will remain. He endeavors "to write himself out of corporeal existence."140 
This late antique death-drive survives as a hagiographical topos into the late Middle Ages. For example, in the South English Legendary (thirteenth c.) vita of St. Margaret (discussed in the last chapter), the young virgin longs for a martyr's death upon hearing the legends of Sts. Stephen and Lawrence. She commands her executioner to do his duty, threatening, "bote pou do pis dede/ pe netit no part perof wip me."141 Given the chance to prolong her life, Margaret refuses. She threatens her executioner with damnation, should he fail to do his job. Though medieval Christian doctrine held suicide to be a grave sin, the "early Christians were the first to develop a full-fledged ideology of martyrdom," one celebrating the Christian's willingness to endure death. $^{142}$

Zealous suicides become saints within the Mandeville-author's uncanny universe. Christ's own sacrificial death inspires this self-annihilating mode of imitatio. Why rejoice over an early and violent death? Because "he is holy that wole deye for his goddes sake."143 Within a Judeo-Christian economy, God demands blood. Anselm's satisfaction theory of atonement held that Christ's death pays the debt of justice owed by humankind to God. Though this became the dominant theory, it was occasionally met with horror. Peter Abelard (eleventh-twelfth c.) exclaims, "How cruel and wicked it seems that anyone should demand the blood of an innocent person as the price for anything... still less that God should consider the death of his Son so agreeable that by it he should be reconciled to the whole world!"144 Yet this is precisely the mystery that passion narratives both rehearse and celebrate. This traumatic core of Christian doctrine creates saints in its image, leaving an indelible mark on Christian sanctity as such. As soon as Constantine legalized Christianity (313 AD), Christians sought alternate ways of participating in martyrdom, a mode of sanctity no longer readily accessible. They analogized martyrdom, performing death through lesser feats of self-denial. ${ }^{145}$ As is only reasonable! These 
Mandevillean devotees, on the other hand, do not attempt to sanitize or mitigate the martyr's exemplarity. They take it literally, offering themselves as blood sacrifices. Lacking a persecutor's hand, they die by their own. The Book's bloody spectacle of devotion to St. Thomas logically extends the cult of the martyr. These devotees appropriate and re-perform the martyr's mode of sanctity, acquiring their own devotees and creating a self-perpetuating chain of martyrs. The Mandeville-author canonizes those who kill themselves not just "for goddes sake," but for love of their patron. Individuals who die for love of a saint become saints themselves. Cultic suicide equates to auto-martyrdom. Sir John offers an analogy in which westerners appear lame by comparison: "And as a man thenketh in our contre that he hath gret worship if he have a holy man to his kyn, so they say that tho that ben slayn ben seyntes." ${ }^{146}$ Whereas westerners are content osmotically to receive sanctity from holy relatives, these devotees pursue sanctity themselves, even unto death.

The Mandeville-author surrounds this excess with the familiar trappings of cultic devotion. Living devotees take "relykes" from the suicides, memorializing them in "letenyes." The text immediately veers from the homely to the unhomely, alienating the reader from otherwise familiar practices. These worshippers "brenne her [the saints'] bodyes," and the relics are actually the ashes. ${ }^{147}$ Premodern Christians viewed cremation with suspicion. ${ }^{148}$ That particular burial practice was coded pagan, whether Greco-Roman or Northern European. The Book keeps tradition and taboo in a tight, dialectical dance, never allowing the reader to rest in her complacency. The differences that make the familiar strange encourage readers to question their cultural defaults and theological assumptions. The Mandeville-author selects cultic devotion as the phenomenon with which to make his point. By turning to the friends of God, 
with whom all Christians craved intimacy, The Book reveals the saint as the stranger at the hearth.

Not until he reaches the Far East does Sir John encounter a living saint. This suggests that saintly living is the rarest marvel of all. As Sir John gets farther away from the corrupt Catholic West, he encounters more and more examples of living holiness. The thirteenth and fourteenth centuries saw a rise in "living sainthood," the veneration of individuals as saints during their lifetimes. The newly formed mendicant orders, of which the Mandeville-author was likely a member, did much to inspire this mode of veneration. ${ }^{149}$ The Brahmin Hindus provide Sir John with the strongest example of sanctity he has encountered in his travels. They enjoy such renown for their "good lyff" - their fair-mindedness, physical moderation, and devotion - that their home has been dubbed "the Ile of Feith." 150 They have eliminated murder, lechery, and poverty. Since they hold all things in common (like the early apostolic communities) and practice moderation, they suffer neither war nor hunger. They never undergo natural disasters or any sort of "tribulacioun." "151 This seems to indicate God's blessing, yet "they be noght Cristen," nor does Sir John imply any sort of miraculous or hidden knowledge of Christ. ${ }^{152}$ If they are conformed to Christ, their faith remains entirely implicit, not even self-aware. In the Legenda aurea, Jacobus de Voragine explains that the Feast of All Saints (Nov. 1) supplies "for the omission of many saints from the calendar" (propter omissorum suppletionem). Even if the church managed to identify these secret saints, it could not possibly fete them all. For "the number of them has multiplied until it is almost infinite." This account of All Saints implicitly theologizes that many holy persons must remain hidden from the institutional church's view, and that they are more numerous than one might expect. ${ }^{153}$ All Saints celebrates the fact that no one can delimit the cloud of witnesses. The Book's project builds on this strain of religious thought, extending the 
possibility of sainthood into the non-Christian realm. The Brahmins' incontestable sanctity challenges Sir John in the same way that the largesse of the Great Khan and the nobility of the Muslim sultan take Christians to task.

The holiness of others does nothing so much as shame Sir John on behalf of Latin Christians. He enjoins them to reform on numerous occasions. After recounting the honorable treatment he has experienced among Muslims, whose doctrine surprises him with its proximity to Christianity, Sir John reveals his chagrin at the Muslims' knowledge of Christians' bad behavior. He laments that "they that sholde be turned [converted] by our good techyng and ensample uppon Cristen feithe, be withdrawe thorgh oure yvel ensample of lyvenge."154 In other words, there is no hope of evangelizing without the exemplarity of sanctified living. For this reason if for no other, Christians should abandon their crusading ethic. What cannot be earned cannot be held through force. Were Christians to reform, they would come into their "right heritage."155 Yet what would inheritance look like if true sanctity was the precondition? Sir John seems to imply that Christian holiness might inspire others to convert, producing a bloodless global unity. (Again, this relatively pacifistic approach should not be confused with cultural relativism.) The power of sanctity is a kind of weakness; it draws others into pilgrimage rather than inciting them to crusade. The experience of a saint (objective genitive) has both an apophatic and an itinerative quality, and, by some mysterious alchemy, these amount to the same thing. ${ }^{156}$ Sainthood is the phenomenon by which Sir John gets his bearings, yet sanctity is indeterminate enough that strangers reflect its strangeness back.

In The Book, the unknowing of travelogue intersects with the mysterious core of sanctity, and this has implications for the question of who can be saved. Sir John refers frequently to "my way," alluding both to the thread of his narrative and to his function as a giver of geographical 
directions. ${ }^{157}$ The repetition of this word also evokes Christ's declamation "I am the way" in the Johannine gospel, suggesting that Sir John's course proves most ultimately the Christian faith (John 14.6). Despite the freighted quality of this word, Sir John's peripatetic narrative brings him repeatedly to things that "toucheth nought to my way." 158 These distractions have a liberating effect upon the text and are perhaps even its point. Sir John recounts several "weyes" one might take to Jerusalem, admitting that there are still more possible itineraries, depending upon one's place of origin. 159 "And thogh hit be so that ther beth many other weyes that men may go by, after the contreis that men cometh fro, and at the laste they cometh to oon eynde," 160 What is the "one end" to which every path "at last" leads? This sweeping reference to Jerusalem evokes more than the Holy Land; it seems to describe the span of a human life. If traversing the way to Jerusalem metaphorically demonstrates the hope of heaven, then the acknowledgement of there being many ways to the city destined for transfiguration (into the heavenly Jerusalem) implies the possibility of religious universalism.

\section{"Other Sheep Have I"}

The Book of John Mandeville insists on the sanctity of the unknowable Other. As we have seen, the Mandeville-author seems primarily concerned with "what people believe."161 From Christian folklore to Near Eastern religiosity to fantastic ritual, the text explores the diversity of religious impulse. We should avoid ascribing neutrality to this text, however. Though the text is unusual for its curiosity and comparative tolerance, Christianity remains the unquestioned assumption beneath its observations. It offers an implicit "theology of religions," a theological enterprise that attempts, from within a set religion, to account for the variety of religious beliefs in the world. A bold enterprise for an Inquisition-era thinker, this hardly counts as relativism. ${ }^{162}$ 
Still, one might advance a universalizing theory of salvation without ceding one's framing salvation narrative.

If non-Christian people have recognizably saintly lives, who can deny their sainthood with certainty? Sir John uses the cultural phenomenon of sainthood as a point-of-entry into God's ineffable will. The apophatic essence of sanctity creates space for a Christian theology of religions. The undeniable, virtuosic examples of goodness that suffuse the space outside the visible church imply that the Body of Christ must extend farther than the explicitly Christian eye can see. The very inclusion of monstrous races on the medieval cartographic landscape "suggests that even such creatures as these are capable of Christian salvation." 163 One might view this as either a forceful imposition of Christianity on the rest of the world or a goodwill desire to include Others within an accepted salvation history. These constitute two poles of one impulse, in fact. Sir John invites his readers to endure the ascesis of epistemological darkness so that they might learn to recognize alternate sanctities.

Only through unknowing can one recognize the saints who reside outside the boundary of one's religion. The parable of Hamschen illustrates this, literalizing the figurative conceit of a contemporary apophatic, vernacular text, The Cloude of Unknowyng (fourteenth c.). The Cloudeauthor suggests that one can know God only by striking at the dark cloud surrounding him (which represents the utter negation of all concepts and ideas) with the "scharp darte of longing love." 164 As on Sinai, this cloud surrounds God's inscrutable essence, yet to experience the cloud is, in some sense, to experience the divine (Exod. 24.16). The Mandeville-author might have this text in mind when he describes "Hamson," converting spiritual metaphor into geo-spatial travel anecdote. Hamschen has long been covered with darkness, which Sir John describes as "a gret mervayl." A Christian town in the midst of hostile neighbors, Hamschen receives the darkness as 
a gift: "And they say that hit is derknesse that cometh thorgh miracle of God that He shewed for Cristen men." "165 This darkness is God's "showing," and behind the darkness reside secret, hidden Christians. The parable reflects the Mandeville-author's longing that the entire world be filled with hidden Christians, especially saintly ones. Somewhere out there is a Prester John, a Chinese emperor who kisses the cross, a sultan who discourses with a friar-if only the darkness would lift. Paradise, of which John "can... nat speke propirly" is another "myrke [dark] londe where no man may see on day ne on nyght."166 The site of primordial blessing, to which humanity longs to return, can no longer be seen. But it exists. It remains a place with a physical location. These hidden "sights" symbolize God's emergent kingdom, which is always to-come, both immanent within and transcendent of history. The cloud surrounding God is mysteriously coidentifiable with his saints, the great "cloud of witnesses" (Heb. 12.1). They surround God's throne, obscuring and revealing his glory.

The Book concludes with an explicit argument for a more inclusive soteriology. Sir John works from within the Judeo-Christian tradition in order to demonstrate that God's providence extends beyond the explicitly Judeo-Christian tradition. Drawing on the idea that Job, from the land of Uz, was not an Israelite, he points out several times that "Jope... was a paynem," yet God "helde hym for His triwe servaunt, and many other." ${ }^{167}$ Exemplars become all the more striking when they are "outsiders" - the Good Samaritan, for example. Referring to the Brahmins, Sir John affirms that, "although hit be so that they have noght alle the articles of our faith, yit Y trowe that God love hem neverthelasse for her good purpoos." 168 This brazen and confident statement invites readers to share the belief that God loves those who are good. Period. Shifting the emphasis, we might say that no one can be good and remain outside of God's love. Sir John does not renounce the articles of the Christian faith, but dogma recedes in importance in the face 
of saintly living. Explicit confession yields priority of place to lived holiness. A "good purpoos" is self-justifying, proof of God's approbation. The Mandeville-author quotes scripture in support of this universality. The "godespell saeth thus... I have other sheep that beth noght of this foold." ${ }^{169}$ In the Gospel According to John, Jesus says, "And other sheep I have, that are not of this fold: them also I must bring, and they shall hear my voice, and there shall be one fold and one shepherd" (John 10.16). Who are these enigmatic other sheep? Where is their fold? What constitutes "this fold"? "Fold" can mean "world" in Middle English, suggesting that there exist many worlds beyond those present to the eye. Some of the Good Shepherd's flock remain unapparent, waiting until eschatological fulfillment to be called. The Mandeville-author also quotes God's admonition to Peter that all things are clean that God calls clean (Acts 10.15). ${ }^{170}$

From these scriptural citations, he draws the simple conclusion that "we wyteth noght wham God loveth most, and wham he hateth most." 171 What words of wisdom does Sir John impart to his readers? What has he learned from his extensive travels? "We wyteth noght." We know not. If one can learn that, then one has learned much. Saintly people - through their outstanding performances of goodness, their promiscuous signification, the omnipresence of their cults, and the variation of their professed beliefs - baffle those who see them. Strange in every aspect but their goodness, they provide the stranger with safe harbor. As Sir John realizes, there is nowhere they are not. Yet no one can search them out. They show the way by showing that "ther beth many other weyes that men may go by... and at the laste they cometh to oon eynde." 172

\section{Notes}

${ }^{1}$ Peter Brown, "The Rise and Function of the Holy Man in Late Antiquity," The Journal of Roman Studies 61 (1971): 91. 
${ }^{2}$ The Book of John Mandeville, TEAMS Middle English Texts Series, ed. Tamarah Kohanski and C. David Benson (Kalamazoo: Medieval Institute Publications, 2007) 27 (line 210).

${ }^{3}$ The Book, TEAMS 21 (lines 22-23).

${ }^{4}$ See John Marenbon, Pagans and Philosophers: The Problem of Paganism from Augustine to Leibniz (Princeton: Princeton University Press, 2015); Ed. István P. Bejczy, Virtue Ethics in the Middle Ages: Commentaries on Aristotle's "Nicomachean Ethics," 1200-1500, Brill's Studies in Intellectual History 160 (Leiden: Brill, 2008); Helen S. Lang, Aristotle's "Physics" and its Medieval Varieties (Albany: State University of New York Press, 1992); Ed. Lloyd A. Newton, Medieval Commentaries on Aristotle's “Categories,” Brill's Commentaries on the Christian Tradition (Leiden: Brill, 2008); Jessica Rosenfeld, Ethics and Enjoyment in Late Medieval Poetry: Love After Aristotle (Cambridge: Cambridge University Press, 2011); Henry Ansgar Kelly, Ideas and Forms of Tragedy, from Aristotle to the Middle Ages (Cambridge: Cambridge University Press, 1993).

${ }^{5}$ The Book, TEAMS 27 (lines 210-213).

${ }^{6}$ Peter Brown, The Cult of the Saints: Its Rise and Function in Latin Christianity (Chicago: University of Chicago Press, 1981): “Tomb and altar were joined. The bishop and his clergy performed public worship in a proximity to the human dead that would have been profoundly disturbing to pagan and Jewish feeling" (9).

${ }^{7}$ Brown, The Cult of the Saints: "Whatever their relation with the ecclesiastical hierarchy, the Christian Mediterranean and its extensions to the east and northwest came to be dotted with clearly indicated loci where Heaven and Earth met. The shrine containing a grave or, more frequently, a fragmentary relic, was very often called quite simply, 'the place': loca 
sanctorum... It was a place where the normal laws of the grave were held to be suspended. In a relic, the chilling anonymity of human remains could be thought to be still heavy with the fullness of a beloved person" (10-11).

${ }^{8}$ The Book, TEAMS 23 (line 66).

${ }^{9}$ André Vauchez, Sainthood in the Later Middle Ages, trans. Jean Birrell (Cambridge: Cambridge University Press, 1997): "On the legal plane, no new text appeared in the late twelfth or early thirteenth centuries until the Fourth Lateran Council... However, a number of solemn declarations by Innocent III confirm that the papacy was by then confident it possessed the privilege of canonizing saints. The bull of canonization of St Cunegund in 1200 contains two important passages which are relevant here; the first concerns pontifical reservation, which is clearly asserted: 'since this sublime judgement belongs solely to He who is the successor of St Peter and the Vicar of Jesus Christ'; the second, for the first time, explicitly relates the power of the pope to canonize saints to his plenitudo potestatis" (27); Thomas Head, "Introduction," Medieval Hagiography: An Anthology, ed. Thomas Head (New York: Routledge, 2001): “The proliferation of such contemporary saints caused clerics to become anxious about their control over the legends and the cults of the new saints. Beginning in the eleventh and twelfth centuries, but decisively in the thirteenth century, the papacy moved to take control of the legal means by which new saints were officially recognized. Such papal canonization involved legal inquiries into the lives of reputed saints [processus canonizationis]... a new form of hagiography..." (xxiii); See also Robert Bartlett, Why Can the Dead Do Such Great Things? Saints and Worshippers from the Martyrs to the Reformation (Princeton: Princeton University Press, 2013); Kenneth L. Woodward, Making Saints: How the Catholic Church Determines Who Becomes a Saint, Who Doesn't, and Why (New York: Simon \& Schuster, 1990). 
${ }^{10}$ E.g., 1 Sam. 2.2, Isa. 6.3, Apoc. 4.8, Apoc. 15.4

${ }^{11}$ Jean-Luc Marion, “The Invisibility of the Saint,” Saints: Faith Without Borders, ed. Françoise Meltzer and Jaś Elsner (Chicago: Chicago University Press, 2011): “God's alterity imposes itself as absolute precisely as the alterity of holiness. And this alterity of holiness is manifested only as it remains invisible" (360).

${ }^{12}$ E.g., Lev. 11.44, 1 Pet. 1.16

13 Thomas Aquinas, Summa Theologiae, ed. and trans. Kevin D. O’Rourke, O.P., vol. 39 (London: Blackfriars, 1964) 30-31. II-II, Q. 81, Art. 8.

${ }^{14}$ Aviad Kleinberg, "Apophthegmata” in Meltzer and Elsner, eds., Saints: Faith Without Borders: "[The saints communicate] different things to different audiences. By contradicting they make unison possible — at least temporarily. On closer look smooth social surfaces always turn out to be mosaics" (395).

${ }^{15}$ Kathryn Kerby-Fulton, Books Under Suspicion: Censorship and Tolerance of Revelatory Writing in Late Medieval England (Notre Dame: University of Notre Dame Press, 2006) 115; Kerby-Fulton locates The Book within a long tradition of mendicant spirituality, which preferred missionary initiatives to martial ones. "Joachite liberalism helped create the popular Franciscan alternative to crusading that by the next century would turn up in vernacular literature like Mandeville's Travels and Piers Plowman" (72).

${ }^{16}$ The Book, TEAMS 21 (line 4); Narratival works often engage in "imaginative theology," allowing theological implications to emerge from poetics and plot. Barbara Newman, God and the Goddesses: Vision, Poetry, and Belief in the Middle Ages (Philadelphia: University of Pennsylvania Press, 2003); Caroline Walker Bynum notes that poetic topoi and images often take over when theological discourse runs out of propositional ways of expressing ideas. 
Caroline Walker Bynum, The Resurrection of the Body in Western Christianity, 200-1336, Lectures on the History of Religions Series 15 (New York: Columbia University Press, 1995) xvi.

${ }^{17}$ Nicholas Watson, "Visions of Inclusion: Universal Salvation and Vernacular Theology in Pre-Reformation England," Journal of Medieval and Early Modern Studies 27 (1997): 145-6; See also Nicholas Watson, "Censorship and Cultural Change in Late-Medieval England: Vernacular Theology, the Oxford Translation Debate, and Arundel's Constitutions of 1409," Speculum 70 (1995): 822-864; Nicholas Watson, "Cultural Changes," English Language Notes 44 (2006): 127-135; The Latin version of The Book attempts to contain and stabilize the unwieldy tradition. This official-seeming version censors some of the most relativistic passages. John of Mandeville, "The Book of John Mandeville" with Related Texts, ed. and trans. Iain Macleod Higgins (Indianapolis: Hackett Publishing Company, Inc., 2011): “[In the Latin translation] a close-minded translator meets an open text... he also dogmatically hardens $T B J M$ 's religious attitudes and even deliberately reverses some of the author's claims" (206).

${ }^{18}$ The Book, TEAMS 90 (line 2637); Andrew Fleck offers a more negative reading of this Christian framework. Andrew Fleck, "Here, There, and In between: Representing Difference in the 'Travels' of Sir John Mandeville," Studies in Philology 97 (2000): 389.

${ }^{19}$ Timothy Ware, The Orthodox Church (London: Penguin, 1963) 63.

${ }^{20}$ Ware 63; Pseudo-Dionysius, "The Mystical Theology,” Pseudo-Dionysius: The Complete Works, ed. John Farina, trans. Colm Luibheid (New York: Paulist Press, 1988) 138, 139.

${ }^{21}$ Religious studies scholars have begun to weave the two threads together more concertedly, arguing for an apophatic materialism. Ed. Chris Boesel and Catherine Keller, 
"Introduction," Apophatic Bodies: Negative Theology, Incarnation, and Relationality (New York: Fordham University Press, 2010): “Apophatic bodies. If the phrase stops the reader short, perplexes, provokes a pause, it will have begun to do its work. Indeed, the modifier 'apophatic' - that which 'unsays' or 'says away' — presses toward the pause and the silence within language. It pauses before the unknowable infinity of: bodies?" (1)

${ }^{22}$ E.g., Vincent Gillespie and Maggie Ross, "The Apophatic Image: The Poetics of Effacement in Julian of Norwich," The Medieval Mystical Tradition in England, ed. M. Glasscoe (Cambridge: D. S. Brewer, 1992) 53-77.

${ }^{23}$ Patricia Cox Miller's work on late antique hagiography affords a notable exception. See Patricia Cox Miller, "Subtle Embodiments: Imagining the Holy in Late Antiquity" in Boesel and Keller, eds., Apophatic Bodies: Negative Theology, Incarnation, and Relationality 45-58.

${ }^{24}$ Iain Macleod Higgins, Writing East: The "Travels" of Sir John Mandeville (Philadelphia: University of Pennsylvania Press, 1997) vii.

${ }^{25}$ Higgins, "The Book of John Mandeville” and Related Texts xiii.

${ }^{26}$ Higgins, Writing East viii; See also C. W. R. D. Moseley, "The Metamorphoses of Sir John Mandeville,” The Yearbook of English Studies 4 (1974): 5-25.

${ }^{27}$ Higgins, Writing East 15.

${ }^{28}$ Stephen Greenblatt, Marvelous Possessions: The Wonder of the New World (Chicago: The University of Chicago Press, 1991) 30-31.

${ }^{29}$ C. W. R. D. Moseley, “'New Things to Speak of': Money, Memory, and Mandeville's Travels in Early Modern England," The Yearbook of English Studies 41 (2011): 5.

${ }^{30}$ Higgins, "The Book of John Mandeville” and Related Texts xiii. 
${ }^{31}$ Donald R. Howard, Writers and Pilgrims: Medieval Pilgrimage Narratives and Their Posterity (Berkeley: University of California Press, 1980) 54.

${ }^{32}$ Colin Morris, "Pilgrimage to Jerusalem in the late Middle Ages," Pilgrimage: The English Experience from Becket to Bunyan, ed. Colin Morris and Peter Roberts (Cambridge: Cambridge University Press, 2002) 143.

${ }^{33}$ Howard 55. Citing Josephine Waters Bennett, The Rediscovery of Sir John Mandeville (New York: Kraus Reprint, 1971) 1-86.

${ }^{34}$ Howard 59.

${ }^{35}$ See, for example, the dragon episode in the South English Legendary "Life of St Margaret." The narrator breaks the flow of action to state, "ac inot weper me lie" (158). Eds. Charlotte D'Evelyn and Anna J. Mill The South English Legendary, Early English Text Society (Oxford: Oxford University Press, 1956) 297.

${ }^{36}$ Molly Lefebure, Samuel Taylor Coleridge: A Bondage of Opium (New York: Stein and Day, 1974) 181. Donald Howard cites this text (p. 4) in his examination of Colderidge's “Kubla Khan." Coleridge fell asleep reading Purchas His Pilgrimage, or Relations of the World and the Religions Observed in All Ages and Places discovered, from the Creation unto this Present (1613), thus attesting the long afterlife that pilgrim literature, if not pilgrimage itself, enjoyed in England.

${ }^{37}$ Larissa Tracy, Torture and Brutality in Medieval Literature (Cambridge: D. S. Brewer, 2012): "The SEL [South English Legendary] and GiL [Gilte Legende] circulated freely in the vernacular at a time when translating biblical texts was considered heresy; the exemplarity of these legends and the defiance of the saints may have inspired a certain amount of heterodoxy" (39). 
${ }^{38}$ Even his status as a knight may have reflected nostalgia for the mythos of the pious soldier, a myth cultivated especially by clerical authors who offered warrior-saints as exemplars to the pillaging martial class. See James B. MacGregor, "Negotiating Knightly Piety: The Cult of the Warrior-Saints in the West, ca. 1070-ca. 1200," Church History 73 (2004): 317-345.

${ }^{39}$ Georgia Frank, "Miracles, Monks, and Monuments: The Historia Monachorum in Aegypto as Pilgrims' Tales," Pilgrimage and Holy Space in Late Antique Egypt, ed. David Frankfurter (Leiden: Brill, 1998) 483, 497, 484, 488.

${ }^{40}$ Jaś Elsner, "Piety and Passion: Contest and Consensus in the Audiences for Early Christian Pilgrimage," Pilgrimage in Graeco-Roman \& Early Christian Antiquity: Seeing the Gods, ed. Jaś Elsner and Ian Rutherford (Oxford: Oxford University Press, 2005) 422; See also Susan Weingarten, The Saint's Saints: Hagiography and Geography in Jerome (Leiden: Brill, 2005).

${ }^{41}$ A phenomenological formulation I borrow from Jean-Luc Marion.

42 The Book, TEAMS 23 (lines 67-68).

${ }^{43}$ Howard, Writers and Pilgrims 61.

${ }^{44}$ Higgins, Writing East: "It is rather a compilation of others' writings, many of them by genuine travelers to the East, put together by someone who may never have traveled anywhere (except to a good library)" (8); Howard: "Travel itself is 'imaginative': travels are fictions to the extent that the traveller sees what he wants or expects to see, which is often what he has read" (10).

${ }^{45}$ The Book, TEAMS 29 (line 305).

${ }^{46}$ Steven Justice, "Did the Middle Ages Believe in Their Miracles?” Representations 103 (2008): "Doubt and controversy not only attended miracles, but were actively cultivated in 
defining them. Procedures of canonization, developed across the twelfth and thirteenth centuries, presupposed the commonsense recognition that some events emerged in natural processes and others did not" (6); Steven Justice, "Eucharistic Miracle and Eucharistic Doubt," Journal of Medieval and Early Modern Studies 42 (2012): "Far from trying to suppress skepticism and speculation into obedient quiescence, these stories are willing to risk them in an effort to prod quiescent and unreflective belief back into life. The doubt they worry about is what transpires, not when the mind starts up, but when it shuts down" (325); Howard: "[The Mandeville-author] keeps a balance between his own credulity and the seeming fantasy of his subject matter, matching the reader's skepticism to his own... [This performed dubiety made the tales] vouched for seem the more authentic" $(65,66)$.

${ }^{47}$ The Book, TEAMS 53 (line 1206).

${ }^{48}$ The Book, TEAMS 59 (lines 1438-1440).

${ }^{49}$ The Book, TEAMS 87 (line 2525).

${ }^{50}$ The Book, TEAMS 87 (line 2525).

${ }^{51}$ The Book, TEAMS 87 (line 2528).

${ }^{52}$ The Book, TEAMS 87 (line 2529).

${ }^{53}$ Jeffrey Jerome Cohen, Of Giants: Sex, Monsters, and the Middle Ages, Medieval Cultures Ser. 17 (Minneapolis: University of Minnesota Press, 1999): "The giant is humanity writ large, a text literally too big to ignore" (xii); Cohen: "The monster is definitionally a displacement: an exhibit, demonstrative of something other than itself" (xiv).

${ }^{54}$ The Book, TEAMS 87 (lines 2530-2531).

${ }^{55}$ The Book, TEAMS 87 (lines 2542-2543).

${ }^{56}$ The Book, TEAMS 87 (lines 2546-2548). 
${ }^{57}$ The Book, TEAMS 23 (line 67).

${ }^{58}$ The Book, TEAMS 71 (lines 1896-1897).

${ }^{59}$ On the figure of the cynocephalus, see David Gordon White, Myths of the Dog-Man (Chicago: University of Chicago Press, 1991).

${ }^{60}$ The Book, TEAMS 94-95 (lines 2828-2832).

${ }^{61}$ See Jaś Elsner and Ian Rutherford, "Introduction” in Elsner and Rutherford, eds., Pilgrimage in Graeco-Roman \& Early Christian Antiquity 5; Howard: "For, as was always true, pilgrimage was a metaphor for human life: life is a one-way passage to the Heavenly Jerusalem and we are pilgrims on it" (6-7).

62 The Book, TEAMS 91 (lines 2705-2706).

${ }^{63}$ The Book, TEAMS 91-92 (lines 2707-2708).

${ }^{64}$ The Book, TEAMS 92 (lines 2710-2711).

65 The Book, TEAMS 92 (line 2731).

${ }^{66}$ The Book, TEAMS 92 (lines 2729-2736).

${ }^{67}$ The Book, TEAMS 92 (lines 2735-2736).

${ }^{68}$ The Book, TEAMS 86 (lines 2507-2508).

${ }^{69}$ Greenblatt 38.

${ }^{70}$ The Book, TEAMS 95 (lines 2852-2853).

${ }^{71}$ The Book, TEAMS 95 (line 2856).

${ }^{72}$ Howard 67.

${ }^{73}$ Greenblatt 50 .

${ }^{74}$ The pilgrim Egeria visited mostly Old Testament shrines, which suggests that these sites had been maintained and honored before the Jesus movement. Deuteronomy 16.16 recounts 
the imperative that Jewish men assemble at Jerusalem, where they worshipped and held regular fairs. John Wilkinson, “Jewish Holy Places and the Origins of Christian Pilgrimage,” The Blessings of Pilgrimage, ed. Robert Ousterhout (Urbana: University of Illinois Press, 1990): "the idea of saints' tombs had a long tradition in Israel, of which there was a revival in the time of the Maccabees" (45-50).

${ }^{75}$ Bartlett 205-210; Recent scholarship on pilgrimage has sought to understand the Jewish origins of Christian pilgrimage even as it attempts to differentiate Christian "pilgrimage" from the sacred mobility of the pagan past. E.g., Scott Scullion, “'Pilgrimage and Greek Religion: Sacred and Secular in the Pagan Polis" in Pilgrimage in Graeco-Roman \& Early Christian Antiquity 111-130.

${ }^{76}$ Kenneth G. Holum, "Hadrian and St. Helena: Imperial Travel and the Origins of Christian Holy Land Pilgrimage” in Ousterhout, ed., The Blessings of Pilgrimage 67, 73-5.

${ }^{77}$ The Book, TEAMS 21 (line 2) .

${ }^{78}$ The Book, TEAMS 22-3 (lines 59-60).

${ }^{79}$ See: Jacques Le Goff, In Search of Sacred Time: Jacobus de Voragine and "The Golden Legend" (Princeton: Princeton University Press, 2014).

${ }^{80}$ The Book, TEAMS 24 (line 98).

${ }^{81}$ The Book, TEAMS 26 (lines 180-197).

${ }^{82}$ The Book, TEAMS 26 (line 201).

${ }^{83}$ The Book, TEAMS 29 (line 299).

${ }^{84}$ The Book, TEAMS 30 (lines 344-345).

${ }^{85}$ The Book, TEAMS 31 (line 369).

${ }^{86}$ The Book, TEAMS 32 (line 413). 
${ }^{87}$ The Book, TEAMS 33 (lines 439-441).

${ }^{88}$ Patrick J. Geary, Furta Sacra: Thefts of Relics in the Central Middle Ages (Princeton: Princeton University Press, 1978): "It is possible, then, to understand how various communities of the central Middle Ages viewed theft as an appropriate means of relic acquisition. Were they in fact seen as true thefts, morally reprehensible and hence sinful, or were they but one more acceptable way of acquiring a saint? The answer to this question is that they were seen as both, sometimes simultaneously, and hence the translationes exhibit a certain tension which is the result of the hagiographers' efforts to justify and glorify a tradition with which they were not altogether comfortable" (108).

${ }^{89}$ The Book, TEAMS 26 (lines 192-193).

${ }^{90}$ The Book, TEAMS 42 (line 784).

${ }^{91}$ The Book, TEAMS 25 (lines 149-150).

92 The Book, TEAMS 25 (line 164).

93 The Book, TEAMS 29 (line 291).

94 The Book, TEAMS 43 (line 831).

95 The Book, TEAMS 35 (lines 510-511).

${ }^{96}$ Ed. M. C. Seymour, The Egerton Version of Mandeville's Travels, Early English Text Society Series (Oxford: Oxford University Press, 2010) 34 (line 4).

${ }^{97}$ Egerton Version, EETS 34 (lines 11-12).

${ }^{98}$ Egerton Version, EETS 34 (line 17).

${ }^{99}$ Egerton Version, EETS 35 (lines 29-30).

${ }^{100}$ Egerton Version, EETS 35 (lines 12-26).

${ }^{101}$ Egerton Version, EETS 35 (lines 29-30). 
${ }^{102}$ Egerton Version, EETS 35 (line 35).

${ }^{103}$ Egerton Version, EETS 35 (line 22).

${ }^{104}$ Egerton Version, EETS 35 (lines 16-17).

${ }^{105}$ Egerton Version, EETS 34 (line 32).

${ }^{106}$ Caroline Walker Bynum points out the tight connection between "miracle" and “marvel.” Caroline Walker Bynum, "Wonder,” American Historical Review (1997): 9.

${ }^{107}$ Greenblatt notes that the sacred rocks of Jerusalem "function as tangible materializations of sacred stories" and are "infused with the manifest will and residual power of their maker" (39).

108 The Book, TEAMS 21 (line 12).

${ }^{109}$ The Book, TEAMS 38 (line 612).

${ }^{110}$ The Book, TEAMS 38 (lines 619-620).

${ }^{111}$ The Book, TEAMS 42 (line 766).

112 The Book, TEAMS 44 (line 866).

${ }^{113}$ The Book, TEAMS 44 (line 837).

${ }^{114}$ The Travels of Sir John Mandeville, ed. and trans. C. W. R. D. Moseley (London: Penguin, 1983) 86.

115 The Book, TEAMS 38 (line 627).

116 The Book, TEAMS 43 (lines 819-820).

${ }^{117}$ Rudolph Otto, The Idea of the Holy, trans. John W. Harvey (London: Oxford University Press, 1958) 7.

118 Alexander Irwin, Saints of the Impossible: Bataille, Weil, and the Politics of the Sacred (Minneapolis: University of Minnesota Press, 2002) 221. 
${ }^{119}$ Kleinberg, "Apophthegmata” in Meltzer and Elsner, eds., Saints: Faith Without Borders 395.

${ }^{120}$ Karl Rahner, "Why and How Can We Venerate the Saints?" Theological Investigations, Vol. III, trans. David Bourke (New York: The Seabury Press, 1977) 23.

${ }^{121}$ Jean-Luc Marion, The Visible and the Revealed, trans. Christina M. Gschwandtner (New York: Fordham University Press, 2008) 119-144.

122 Jean-Luc Marion, “The Invisibility of the Saint” in Meltzer and Elsner, eds., Saints: Faith Without Borders 355-62.

${ }^{123}$ Howard 67.

${ }^{124}$ The Book, TEAMS 29 (line 278).

${ }^{125}$ The Book, TEAMS 50 (lines 1078-1080).

${ }^{126}$ The Book, TEAMS 50 (lines 1082-1085).

${ }^{127}$ See Higgins, “The Book of John Mandeville” with Related Texts 221-235.

${ }^{128}$ For an overview of the various forms of Christianity to emerge from the Jesus movement, see Bart D. Ehrman, The Lost Christianities: The Battles for Scripture and the Faiths We Never Knew (Oxford: Oxford University Press, 2003).

129 The Book, TEAMS 45 (line 898).

${ }^{130}$ The Book, TEAMS 50 (lines 1093-1094).

131 Tamarah Kohanski and C. David Benson, "Index," The Book, TEAMS 162.

${ }^{132}$ The Book, TEAMS 50 (line 1100).

${ }^{133}$ The Book, TEAMS 49 (lines 1067-1068).

${ }^{134}$ The Book, TEAMS 64 (line 1626).

${ }^{135}$ The Book, TEAMS 64-5 (1638-1658). 
${ }^{136}$ Caroline Walker Bynum, Holy Feast and Holy Fast: The Religious Significance of Food to Medieval Women (Berkeley: University of California Press, 1987): “Christianity is different from the other world religions - none of which has quite this emphasis on the glory and salvific potential of suffering flesh" (418); See also Rudolph Bell, Holy Anorexia (Chicago: University of Chicago Press, 1985) 24; Geoffrey Galt Harpham, The Ascetic Imperative in Culture and Criticism (Chicago: University of Chicago Press, 1987); Howard: “[Mandeville] describes religions that parody Christianity — parody the death-loving, pessimistic side of medieval Christianity with its emphasis on martyrdom, 'mortification,' 'contempt of the world.' We encounter 'saints' who kill themselves for the love of an idol; their kinsmen who collect and worship the 'saint's' relics" (73).

${ }^{137}$ James Benn, “Spontaneous Human Combustion: Some Remarks on a Phenomenon in Chinese Buddhism," Heroes and Saints: The Moment of Death in Cross-cultural Perspectives, ed. Phyllis Granoff and Koichi Shinohara (Newcastle: Cambridge Scholars Publishing, 2007) 117.

${ }^{138}$ See William E. Deal, Handbook to Life in Medieval \& Early Modern Japan (New York: Facts on File, 2006); Andrew Rankin, Seppuku: A History of Samurai Suicide (New York: Kodansha USA, 2011).

${ }^{139}$ Prudentius, Liber Peristephanon from Prudentius, trans. H.J. Thomson, Loeb Classical Library 398 (Cambridge: Harvard University Press, 1953): “Hic, hic amator iam, fateor, placet: ibo inruentis gressibus obviam, nec demorabor vota calentia” (342-3).

${ }^{140}$ Elizabeth A. Castelli, Martyrdom and Memory: Early Christian Culture Making (Columbia: Columbia University Press, 2004) 80. 
${ }^{141}$ The South English Legendary: "Of seinte Steuene heo hurde telle and of sein Laurence also/ Hou in stronge martyrdom hi were to depe ido/ And of oper martirs ek pat polede pine here/ Heo ne wilnede nozt so muche as to beo hore yuere" (292); See also The South English Legendary 301.

${ }^{142}$ Candida Moss, Ancient Christian Martyrdom: Diverse Practices, Theologies, and Traditions (New Haven: Yale University Press, 2012) 1.

143 The Book, TEAMS 65 (line 1641).

${ }^{144}$ Peter Abelard, "Exposition of the Epistle to the Romans," in A Scholastic Miscellany: Anselm to Ockham, trans. and ed. Eugene Fairweather (New York: Macmillan, 1970) 282-83. Quoted in John Parker, The Aesthetics of Antichrist: From Christian Drama to Christopher Marlowe (Ithaca: Cornell University Press, 2007) 71.

${ }^{145}$ See Catherine Sanok Her Life Historical: Exemplarity and Female Saints' Lives in Late Medieval England (Philadelphia: University of Pennsylvania Press, 2007).

146 The Book, TEAMS 65 (line 1665).

${ }^{147}$ The Book, TEAMS 65 (line 1667).

${ }^{148}$ Bynum, Resurrection of the Body: "He [Tertullian]... explains that Christian opposition to cremation has nothing to do with a need to preserve cadavers. Christians prefer to treat corpses gently out of respect, he says, but death is absolute" (48); Caroline Walker Bynum, Fragmentation and Redemption: Essays on Gender and the Human Body in Medieval Religion (New York: Zone Books, 1992): “As one of the more conservative theologians might have said: Material continuity is identity; body is univocal; the whole will rise and every part is in a sense the whole" (294). 
${ }^{149}$ Aviad Kleinberg, Prophets in Their Own Country: Living Saints and the Making of Sainthood in the Later Middle Ages (Chicago: University of Chicago Press, 1992).

${ }^{150}$ The Book, TEAMS 87 (line 2580).

${ }^{151}$ The Book, TEAMS 88 (line 2586).

${ }^{152}$ The Book, TEAMS 88 (line 2574).

${ }^{153}$ Jacobus de Voragine, The Golden Legend, trans. William Granger Ryan (Princeton: Princeton University Press, 2012) 658, 659; Jacobus a Voragine, Legenda aurea, ed. T. Graesse (Osnabrïck: Otto Zeller Verlag, 1969) 718; According to Karl Rahner, All Saints encompasses "anonymous... unknown saints who have not made any general impact in the Church and are not mentioned in her praises." (24).

${ }^{154}$ The Book, TEAMS 56 (line 1328).

${ }^{155}$ The Book, TEAMS 22 (line 42).

${ }^{156}$ Petra Turner points out the "itinerarian themes" needed to theorize the holy. Petra Turner, "The Unknown Saint: Reflections on Jean-Luc Marion's Understanding of Holiness," The Postmodern Saints of France: Refiguring 'the Holy' in Contemporary French Philosophy, ed. Colby Dickinson (London: T\&T Clark, 2013) 244.

157 The Book, TEAMS 28 (line 275).

158 The Book, TEAMS 28 (line 275).

${ }^{159}$ The Book, TEAMS 53 (lines 1186-1192).

${ }^{160}$ The Book, TEAMS 53 (line 1188).

${ }^{161}$ Howard 67.

162 Greenblatt 50.

${ }^{163}$ Higgins, Writing East 144. 
${ }^{164}$ The Cloud of Unknowing, ed. Patrick J. Gallacher, TEAMS Middle English Texts

Series (Kalamazoo: Medieval Institute Publications, 1997) 36.

165 The Book, TEAMS 81 (lines 2310-2311).

166 The Book, TEAMS 91 (lines 2698-2699).

${ }^{167}$ The Book, TEAMS 60, 89 (lines 1463, 2623-2624).

${ }^{168}$ The Book, TEAMS 89 (line 2622).

${ }^{169}$ The Book, TEAMS 90 (lines 2629-2630).

${ }^{170}$ The Book, TEAMS 90 (lines 2630-2637).

${ }^{171}$ The Book, TEAMS 90 (line 2637).

172 The Book, TEAMS 53 (line 1188). 


\section{CHAPTER THREE}

\section{Alien Intercession: The Communion of Saints in Pearl}

...one should say that the refreshment of the saints is not understood by us, unless by a corporeal image. - Nicholas of Lyra ${ }^{1}$

Of his bones are coral made;

Those are pearls that were his eyes:

Nothing of him that doth fade

But doth suffer a sea-change

Into something rich and strange.

- The Tempest ${ }^{2}$

“[T]here sayntes sete," the Pearl Maiden says, describing Christ's heavenly retinue. ${ }^{3}$

Heaven is the state of being a deceased holy person, reborn into a new mode of life. It is spiritual proximity to God, maximal illumination. Metaphorically speaking, it is the place where the saints go when they die. Thomas Aquinas argues that, in heaven, the saints see God in his essence. ${ }^{4}$ The concept of sainthood is fundamental to a comprehensive understanding of the fourteenthcentury Middle English poem Pearl. Though the narrator never describes the Pearl Maiden as a "saint," the theological and aesthetic realities of medieval cultic devotion are implicit throughout the poem. Additionally, the Pearl Maiden identifies her own company as one of "sayntes." Various aspects of Pearl would have evoked specific saints, certain feast days, the communion of saints, and/or the general idea of sainthood for both lay and clerical readers. These evocations render sainthood less a theme or motif than a governing principle of the work. Pearl depicts a transfigured and glorified humanity. The narrator paints a portrait of the church triumphant - the souls resting in paradise, enjoying the beatific vision while they await the general resurrection.

Pearl takes as its subject matter the communion of saints. The Pearl Maiden, though she engages with the Dreamer individually, belongs to a heavenly retinue. Both Dreamer and reader peer into heaven's courts, a place where "sayntes sete." This vision of heavenly community was 
celebrated most explicitly in the Feast of All Saints. Pearl responds to liturgical and hagiographical texts related to this feast. It does so both in its inquiry into the possibilities of posthumous relationality and in its citation of the Book of Apocalypse, from which the poet borrows the 144,000 virgins with which he populates heaven. Apocalypse featured largely in liturgical readings for Allhallowtide (Oct. 31-Nov. 2), and Pearl draws on this cultural context as much as it does the scripture itself. The poem acts as a theological investigation of the communion of saints, but it also draws on one particular hagiographical tradition: the virgin martyr legend. The repetition of "pearl" evokes Saint Margaret, whose name means pearl, as Jacobus de Voragine notes in the Golden Legend entry devoted to her. The poem borrows a number of stock topoi from the virgin martyr archetype, a cultural phenomenon with which its readers and hearers would have been extremely familiar. If on a macro level the poem addresses the communion of saints, then on a micro level it explores the mechanics of saintly intercession. For the Pearl Maiden has momentarily "left" the retinue in order to admonish and encourage one who has fallen asleep on her grave. Mourner and maiden engage in a dialectic intended to sanctify the Dreamer, even if it makes his sainted relation seem cold and remote.

A pervasive alienness surrounds the Pearl Maiden like a cloud, limiting her accessibility to the Dreamer. This opacity stems in large part from her sanctified state. Medieval devotees imagined saints as both approachable and elusive; they stood at the crux of neighborliness and alterity. The traditions of cultic devotion (relic veneration, pilgrimage, and so on) insisted on the possibility of intimacy while betraying a sense of trauma at the distance between the living and the holy dead. Cultic devotion has "at its core a social desire for kinship that is settled in the cosmos." "This "social desire" for communion with the saints strives for closeness while highlighting the gaps that need overcoming. The Pearl Maiden's alien habitus is in keeping with 
the apophatic strain in hagiography that this project attempts to excavate. It makes sense that such an epiphanic text—revealing sanctity's telos as otherworldly beatitude-would foster a sense of mystery, experienced by the dreamer as befuddlement. The history of cultic devotion can be told in two ways: as an Incarnational fantasia or as separation anxiety. Both emphasize longing for contact with the saints, focusing on either their availability or elusiveness. These accounts map onto two distinct but complementary threads of thought: apophatic theology (via negativa) and cataphatic theology (via positiva). Apophasis emphasizes God's inscrutability, seeking ways to unsay statements about the divine. Cataphasis focuses on God's linguistic affirmability and the holy's tangible presence, afforded in the sacraments and, most ultimately, the Incarnation. Rather than view these approaches as opposed, most theologians see them as mutually reinforcing, two sides of one coin. Much has been said about the cataphatic nature of cultic devotion; less about its apophatic aspects.

In recent years, theologians and scholars of religion have begun to put sainthood in dialogue with apophatic theology. This conversation remains small and has yet to be heartily joined by literary scholars. A recent collection on apophatic embodiment contains one essay on hagiography by Patricia Cox Miller. Concerned about idolatry, late antique hagiographers qualified the bodies of their subjects through various textual techniques that rendered them indeterminate. Cox argues that such techniques produce an "apophatic body" or "subtracted self," developing an aesthetic of "subtle embodiment." Another branch of the conversation is taking place within phenomenological studies. Theologians interested in the experience of sainthood wonder what one perceives when one perceives embodied holiness. What does it mean to see a saint as a saint? Jean-Luc Marion, known chiefly for his theory of the saturated phenomenon, addresses the question of saintly phenomenality in an essay entitled "The 
Invisibility of the Saint" (2009). The essay is short and stark. In it, he offers the startling claim that, "No one has ever seen a saint. For the saint remains invisible, not by chance, but in principle and by right." Holiness, he contends, is the very site of God's alterity. When saints participate in God's holiness, they are swept up into a phenomenon that exceeds human perception. He bolsters this argument with the claim that Christ's divinity was least visible at the moment of his death, the paradoxical pinnacle-nadir of his holiness. Death functions similarly to holiness, he argues, and the two often intersect. It is at the crux of these phenomena that the Dreamer encounters the Pearl Maiden. Petra Turner elaborates this theory, drawing on Marion's previous work to clarify his jarring assertions about sainthood. Excessive in its intuition (or overflow of phenomenality), sainthood is not impoverished-it is super-plenteous. It overflows the perceiver and can be experienced only as an impact, not as an object. This impact inscribes itself on the individual as a sense of "moral or ethical disparity." A saintly encounter comes with the imperative to change one's life and is experienced as an "interplay of recognition and ignorance." ${ }^{8}$ Pearl also imagines an encounter with sainthood as dialectical. The poem notices something about the structure of holiness centuries before philosophers of experience arrived at similar conclusions. Medievalists have much to contribute to a conversation about the apophatic side of sanctity. They can provide the phenomenology of holiness with a prehistory.

The apophatic aspects of cultic devotion require excavation because they are the traces upon which layers of cataphatic engagement have sedimented. Peter Brown has noted the extent to which cultic devotion was developed in order to conjure or recapture the saint's physical praesentia. $^{9}$ In their controversial but magisterial work on pilgrimage, Edith and Victor Turner describe pilgrimage as a "therapy of distance." 10 The saint's metaphysical distance gets reduplicated in the physical remoteness of the shrine. Overcoming the latter simulates - and 
perhaps even effects - an overcoming of the former, a therapeutic remedy for the separation anxiety haunting cultic devotion. The saintly absence for which cultic activities compensated proved the mysterious flipside of heavenly patronage. If saints truly participate in God's holiness, then they must stand at a remove from those less intimate with the divine. The most influential text of apophatic theology—the Mystical Theology of Pseudo-Dionysius (fifth-sixth c.) - describes the supra-being of God, who exceeds sense perception, conceptual understanding, and being itself. According to this theology, the Word is only "made manifest to those who travel through foul and fair, who pass beyond the summit of every holy ascent, who leave behind them every divine light, every voice, every word from heaven, and who plunge into the darkness where... there dwells the One who is beyond all things." 11 The contemplative may be able to achieve some kind of temporary union with God, but the experience (if experience it can be called) must ultimately remain indescribable. ${ }^{12}$ The imagery of ascension refers indirectly to the soul's quest for heaven, imagined as "up there." Indeed, the discipline of contemplation lay at the heart of the monastic "devotion to Heaven." 13 The Cloude of Unknowyng, authored by an anonymous contemporary of the Pearl-poet, follows in the Pseudo-Dionysian tradition. (Indeed, the Cloude-author translated the Mystical Theology into the vernacular.) It describes God as surrounded by a "thicke cloude of unknowyng" that one must "smyte... with a scharp darte of longing love." ${ }^{14}$ On the one hand, this cloud represents the epistemological no-man's-land described by Pseudo-Dionysius: God cannot be cognitively comprehended. Yet the cloud can be broached by means of love. The cloud of unknowing alludes to the cloud that descended on Sinai, mentioned in Exodus, but it also evokes the Pauline "cloud of witnesses" imagined to surround God's throne (Heb. 12.1). This Janus-faced company keeps its eyes on God even as it encourages living Christians to run the race. It has all the mystery of a cloud, both surrounding 
and blocking God, permeable but opaque. ${ }^{15}$ The nebulous enclosure surrounds and showcases God. It is the ultimate reliquary. Its very proximity to divinity renders it mysterious. This is the communion of saints.

\section{Pearl and Apophatic Theology}

The Dreamer concludes his lengthy blazon of the Pearl Maiden's splendor with the confession that, "A mannes dom moght dryyly demme/ Er mynde moght malte in hit mesure" (“A man's judgment might greatly dim before the mind could take its measure"). ${ }^{16}$ The Dreamer's mind darkens before this apparition of sanctity. ${ }^{17}$ This dimming of mental faculties is reminiscent of the "darkness so far above light" celebrated by Pseudo-Dionysius, the Cloudauthor, and later John of the Cross. ${ }^{18}$ Here, the spectacle that blinds the mind's eye is one of beatified humanity. Paradoxically, though, this transcendent phenomenon gives itself to the Dreamer through the hyperreality of material richness, and to the reader through an intricate and lapidary poetic form. ${ }^{19}$ The poem negotiates this tensile relationship between material appearing and the transcendent substance of that appearing, implying that the gemlike quality of heaven and its residents is itself a translation of otherwise imperceptible realities. Heaven translates itself into dream; the narrator translates that dream into an account; the poet translates the account into an art object. Word-pictures of the holy require a good deal of textual maneuvering in order to prevent reification and idolatry. The stakes are even higher when the holy appears within God's immediate "vicinity": heaven.

For medieval thinkers, dream visions were generically linked to the contemplative tradition. There were many kinds of dreams - some demonic, some divinely inspired, and some with purely naturalistic explanations. A. C. Spearing points out that the Macrobian terminology used to discuss dreams in naturalistic terms was adapted by spiritual writers in order to interpret 
visionary experiences. ${ }^{20}$ Richard of St.-Victor includes in his catalogue of dreams the somnium mentis, in which the dreamer transcends her own cognitive faculty: "Thus to see a dream is to pass over in the mind into the secret place of divine contemplation. Hence he sleeps and sees a dream who, through ecstasy of the mind, rises into the contemplation of divine things." 21 The "sleep of the mind" is one iteration of the visio spirituale described by Augustine, in which "spiritual forces affect the imagination as if they were sensory images."22 The Pearl Maiden uses this terminology to describe John of Patmos, saying, "The apostel hem [Christ] segh in gostly drem" ("The apostle saw him in a spiritual dream"). ${ }^{23}$ Apophatic theology is deeply intertwined with what has come to be called "bridal mysticism," but which might be more comprehensively described as contemplatio. ${ }^{24}$ In its attempt to commune with the divine, the soul leaves the mind behind, the mind is blinded by holy spectacle, or the mind receives a visio-allegorical image of an otherwise ineffable reality.

The Dreamer himself describes his dream as a kind of rapture. "Fro spot my spyryt ther sprang in space" ("My spirit sprang from that spot into space"). ${ }^{25}$ His vision resembles the raptus described by Paul (2 Cor. 12.2). The Dreamer's spirit goes from being rooted in its bodily locale - its specific spot - to being unconfined by place: spotless. This state of spotlessness to which it springs is an immaterial reality, without a locus, referring to heaven before the general resurrection and return of the saints' bodies. It is also an utterly sanctified reality, spotless because souls "there" lack the stain of sin. The tag in the preceding stanza set is "perle wythouten spot," the "without spot" contrasting neatly with the specific spot from which the Dreamer has sprung. The last word of Fitt I ("wythouten spot") links to the first words of Fitt II ("Fro spot"). Still possessing a body and a sinful nature, the Dreamer finds himself disoriented in this spotless "place." Spearing notes that the Christian visionary is not an epic hero like 
Odysseus or Aeneus, but typically a "saint or holy man for whom the other world is not one of wailing ghosts and unreality, but is more real than this world." ${ }^{26}$ Unlike Paul and John, though, the narrator of Pearl is not especially sanctified or prophetic. He is perfectly average, poignantly human. His vision of sanctity cannot be understood as possessive ("sanctity's vision") but as an objective genitive (“a vision of sanctity," i.e., "sanctity is seen by him"). If even saints find visions of heaven baffling, then no wonder the hapless Dreamer stands "as style as dased quayle" (“as still as a dazed quail"). ${ }^{27}$ Heaven produces an experience of unknowing in the Dreamer, highlighting his ignorance and earthliness.

If heaven cannot be comprehended, then it must necessarily resist aesthetic depiction and linguistic description. This is a problem for the Dreamer, the narrator, and for the Pearl-poet himself. Apophasis is primarily a linguistic term, of which paralipsis is a type. It constitutes the rhetorical technique of speaking away or unsaying what has been said. In Pearl, heaven's inarticulability is bound up with human loss. Ann Chalmers Watts examines the poem's reliance on the "inexpressibility topos." She compares Pearl to a long tradition of mourning poems that insist on the incommunicability of the experience of loss. Paradoxically, "words say that words cannot say" and so "words keep loss present"; in Pearl, however, the narrator "is moved to inexpressibility not directly by his loss but by his dream of unspeakable beauty," which slightly modifies the traditional inexpressibility topos. ${ }^{28}$ The separation occasioned by death is mirrored in the separation between language and the reality it describes. Pearl redirects the linguistic challenges of mourning toward the description of an otherworldly reality. According to David Aers, death challenges human identity by shattering "networks in which human identity is created and sustained." 29 Separation from loved ones makes the self a question to itself. Human identity is contingent upon relationality. Another scholar links the alliterative vernacular form to 
these thematic concerns about linguistic failure. The "low" alliterative form was "prone to infelicities of style, because of its dependence on conventional devices left over from an earlier, simpler age when performance... was oral." ${ }^{30}$ The Pearl-poet exploits these awkward vestiges of orature to emphasize heaven's resistance to poetic rendering. Both its cataphatic description and its apophatic unsaying highlight the Dreamer's cognitive limitations.

The poem itself, though a luminous example of medieval word-craft, draws attention to the troubled relationship between its content and the words used to express it. On the one hand, the narrator insists, "I in speche expound" the vision, and, indeed, Pearl consists of several lavish, hyper-visual constructs. ${ }^{31}$ It is not difficult to envision the bright, mineral figures he describes. The narrator's eloquence does not extend to the Dreamer, who sees much ("thou may wyth yyen me se," the Pearl Maiden concedes) but finds it unintelligible. ${ }^{32}$ Almost every time he responds to the Pearl Maiden with questions or observations, he incurs a rebuke. Trying to break through her seeming imperviousness to his suffering, the Dreamer outlines the ways in which he has "ben a joyless juelere." 33 Confronted with the egoistic pangs of human mourning, she "soberly" insists that "ye haf your tale mysetente" ("you have mistakenly construed your account"). ${ }^{34}$ The Pearl Maiden critiques not only the way he has articulated his story, but its very conception. It has miscarried, and this becomes apparent in the Dreamer's mode of speech. From the Old French mesentendre, "mysetente" means to mis-intend (Latin, in + tendere). The etymology of "intend" is to "stretch, distend, or aim toward or into." One's intention is an unfurling of some aspect of one's self toward another; in this case, by way of a verbally communicated idea. The Dreamer has, through speech, stretched toward the Pearl Maiden either in the wrong manner or in the wrong direction. The Dreamer contrasts markedly with John of Patmos, whose text the poet quotes. John asks the right questions because they are provided by 
the vision itself. Indeed, in Apocalypse, the vision asks questions of John, who replies, “I don't know," and so receives answers. ${ }^{35}$ John uses only the appropriate "termes" to describe the New Jerusalem because - according to the logic of the text - he receives those terms instead of producing them himself. ${ }^{36}$ The Dreamer resists accepting his vision's (or the Pearl Maiden's) terms. In fact, the Dreamer might be understood as having been dropped into John's vision, considering the Pearl-poet's heavy reliance on Apocalypse. Someone has already written the text, has already had this same vision. The Dreamer must therefore submit to a process of exegesis - to the logic of another's "ghostly dream," one with scriptural authority. The moment he invents his own terms by leaping into the river, he gets ejected from the dream. Throughout the poem, the Dreamer tries to set the terms for his relationship to the Pearl Maiden.

His insistence on setting the terms leads him into a dialectic with the Pearl Maiden. The dialectical process lends itself to an exploration of the incomprehensible, inviting the interlocutors deeper into a mystery without ever resolving it wholly. It constructs a language that "must more or less openly disavow itself, forcing the reader to look not only beyond words, but beyond the diachronic world in which we (apparently) exist." ${ }^{37}$ Dialectic proliferates words, and presumably insights, fostering wisdom without settling on a definite formulation of reality. The Dreamer would like to settle the terms, but the Pearl Maiden keeps drawing her interlocutor into a place of unknowing. She answers the Dreamer's questions, yet her chastising responses suggest that the Dreamer ought to adopt a quiet, contemplative attitude toward his vision. The Dreamer contrasts with Christ who, the Pearl Maiden says, "closed... hys mouth fro uch query" when faced with the prospect of suffering and death. ${ }^{38}$ In contradistinction to the Word's eloquent silence, the Dreamer peppers his loved one with questions and self-justifications. She responds to his plaint by explaining that living things resemble the rose, which withers and fades. To this he 
timidly suggests that he might be happy if he could only cross the river to join her. Again, she chides him about his misuse of language: "Thre wordes has thou spoken at ene;/ Unavysed.../ Thou ne wost in worlde quat on dos mene;/ Thy worde byfore thy wytte con fle" ("You have spoken three things in one, unadvised. You have no idea what even one means. Your speech flies before your wit")..${ }^{39}$ The Dreamer speaks without knowing, his words dislocated from the reality they attempt to describe. Yet he will speak. The Dreamer feebly upholds his end of the dialectic by unfurling tendrils of his speech toward the unknown. His words reach beyond what knowledge and understanding he already possesses, yet their blind groping sends back new information. Unlike the mute Lamb or the contemplative who has broached the silent, "unheardof canticles" of heaven, the Dreamer confronts his unknowing with linguistic striving. ${ }^{40}$

The Pearl-poet does the same, though with studied artistry as opposed to dialectical befuddlement. Close to but perhaps distinguishable from the poet's own voice is that of the narrator. Though he stands apart from the Dreamer's confusion, the narrator both recapitulates the dialogue and surrounds it with lavish description. Presumably, the narrator recounts everything with the benefit of waking-hour hindsight, no longer caught in the moment of (non)recognition or subject to the transcendent logic of heaven. The poet, of course, constructs it all. The relationship between these three figures is a much-debated aspect of Pearl, and it is important not to collapse Dreamer, narrator, and poet into one.

The poet, for his part, has the task of "figuring the unfigurable." 41 The words that the characters exchange are not the only words in the poem, nor are they the only ones that strive toward the unknown. Barbara Newman contrasts “the Maiden's blunt, even rude vernacular and the supremely artificial structure that contains her. ${ }^{, 42}$ Some discussions of the imagery in Pearl 
emphasize the radical alterity of heaven. J. Allan Mitchell, for example, argues that the poem

completely disavows language's ability to represent anagogic reality:

As is customary to note, the otherworld in Pearl is ultimately incommensurate with human language and logic, abstracted from time and space, and therefore fundamentally alien to the expressions we invent to speak of that realm - the truly undiscovered country. ...commentators have thus variously argued that the poem engages the vast representational problem of verbal revelation: it is said that the Pearl-poet uses paradox, illogical cruxes, the inexpressability [sic] topos, aenigma, word-play, and mixed styles to problematize verbal discourse on heavenly realities. So while the text resists the figural view in particular, it is involved in a co-extensive negative and perhaps nominalist critique of religious language in general. The radical alterity of Heaven calls into question the traditional repertory of religious language or 'God-talk' (those parables, analogies, and figures adduced for the purpose) that one inevitably brings to bear on the subject. ${ }^{43}$

Lusty declamations of theological language have become part and parcel of a postmodern theology increasingly divorced from traditional apophatic thought. They serve as useful reminders of the divine's otherworldliness, yet remain stuck on one side of the dialectical pendulum. These studies cite "the negative epistemology of Pseudo-Dionysius" without reference to the Neo-Platonist's other, highly cataphatic works. ${ }^{44}$ If the Pearl-poet was influenced by Pseudo-Dionysian thought (as he certainly was), his project is as likely to lean on the Divine Names as to offer a critique of religious language as such. Piotr Spyra states, "The general picture of the disjunction between heaven and earth presented by the Pearl-Poet is bleak. ...the two worlds cannot be bridged..."45 Truly, the poet does not provide a literal bridge across which the Dreamer might venture. Only death enables one to cross over. Yet it matters that the Pearl Maiden somehow "leaves" her heavenly abode for a wider orbit. Or, to put it another way, she miraculously includes a beleaguered loved one within her beatific gaze. He is not overlooked. He receives gracious welcome. She bows, removes her crown, and greets the Dreamer ("Enclynande lowe in wommon lore,/ Caghte of her coroun of grete tresore/ And haylsed me..." "Bowing low in a womanly manner, she removed her precious crown and hailed 
me"). ${ }^{46}$ This greeting is striking for its humility and grace. Both transfigured and queened by heaven, the Pearl Maiden bows low and removes the sign of her elevated state. She does this even before the Dreamer has greeted her; he is her guest. Most importantly, she ventures contact by way of spoken communication: "Ho proffered me speche" ("She offered me speech"). ${ }^{47}$ While "haylsed" can mean "to greet," it homonymically evokes "halsen," which means "to interpret a dream" or to "beseech God." The Pearl Maiden will do both of these things for the Dreamer. The bulk of the poem consists of her helping him to make sense of his dream. We will return to the question of intercession. The desire on both sides is for contact and understanding. However absolutely different their states of being, the intentionality of love draws them together. Most medieval writers would hardly have embraced such a totalizing rejection of religious language or symbolism. Especially the Pearl-poet, much of whose language is simply scriptural quotation and citation (e.g., Apocalypse, the Parable of the Vineyard). Indeed, scholars have noted that these passages rely less on poetic prowess than on re-description of biblical texts, a topos popular with medieval readers yet often viewed as a literary "failing" by modern critics. ${ }^{48}$ What might strike twenty-first-century readers as dull and conventional, however, imbued medieval texts with the heft of scriptural authority. What these hyper-apophatic readings occlude is the Incarnational reality central to Christian doctrine: that the Word became flesh, and himself used language to paint word-pictures. Even the most accomplished contemplative was firmly grounded in a liturgical, ecclesial, and sacramental context. The poem's very existence mitigates too apophatic of a reading. As Theodore Bogdanos puts it, "The hero-narrator pleads at some point the ineffable. But the poet continues speaking, inspired by that silence into effulgent eloquence..." ${ }^{, 49}$ Bogdanos laments overly negative readings of Pseudo-Dionysius, because they lose sight of the indispensable process of aesthesis. The apophatic "dissimilar similitude" relies 
both on difference and sameness, and there is no utterly self-transcending symbol. ${ }^{50}$ For medieval Christians embedded within a sacramental economy, there need not be. Traces of the negative scour and shadow the positive. They enhance its mystery without altogether effacing it. If Pearl is a textual image of the ineffable, it remains an image.

\section{The Virgin Martyrs}

Critics have noted the poem's participation in many genres, with examples including dream vision poetry, apocalyptic writing, courtly love poetry, biblical exegesis, lapidary, spiritual visio, and tales of the faerie Otherworld or heaven. Yet hagiography has seldom been examined as a literary context for Pearl. This is surprising, since the poem explores heady issues regarding the communion of saints and the dynamics of intercession. More colloquially, though, the poem's aesthetic links it to a popular subgenre of hagiographical literature. The Pearl Maiden's resemblance to the virgin martyrs imbues her with a host of connotations. James W. Earl explored this similitude four decades ago in a brief article. Though he was not the first to note this connection, it has remained an understudied aspect of Pearl. In "Saint Margaret and the Pearl Maiden," Earl investigates the relatively obvious fact that another pearl maiden loomed large in medieval Europe. ${ }^{51}$ The Pearl-poet occasionally refers to pearls as "margarys" or "mariorys," using the Latinate word for "pearl" (margarita) ${ }^{52}$ Margaret was a common name in medieval Europe, in part thanks to the immense popularity of Saint Margaret of Antioch (fourth c.). One colorful episode makes Margaret's otherwise typical virgin martyr legend stand out: she is swallowed by a dragon and erupts from its belly. This tableau captured the medieval imagination, generating a great deal of iconography. ${ }^{53}$ She was one of the Fourteen Holy Helpers as well as one of the saints from whom Joan of Arc claimed to have received messages. Thanks to the pervasiveness of her cult, Margaret became an almost archetypal virgin martyr. A mind 
grasping for a template through which to envision the Pearl Maiden might quickly and subconsciously select that of Saint Margaret.

In addition to lapidaries and biblical texts, Earl argues, Pearl draws on this hagiographical context. ${ }^{54}$ The poem's refrain "precios perle" echoes the most popular Western version of Margaret's vita. Each life in the Golden Legend (thirteenth c.) begins with a fanciful etymology. The opening lines of Margaret's vita linger over the connotations of her name: “The name Margaret is also the name of a precious (pretiosa) jewel called margarita, pearl, which is shining white, small (parva), and powerful. So Saint Margaret was shining white by her virginity, small by humility, and powerful in the performance of miracles." ${ }^{, 55}$ The Pearl-poet uses a similar set of adjectives, including "precious," of course, but also "small." Gazing on the Pearl Maiden, the Dreamer describes her as "So smothe, so small, so seme slyght" ("So smooth, so small, so becomingly delicate"). ${ }^{56}$ Something about a pearl's smooth, white curvature makes it seem especially miniature and graspable. Both Jacobus and the Pearl-poet apply "small" to a feminine subject identified with a' pearl. In both works, these lapidarian descriptions produce an erotic subtext. Spearing has pointed out that "sydez could mean either the surface of a pearl or the flanks of a woman. ${ }^{\circ 7}$ The Golden Legend interprets parva tropologically (as humility), yet has it both ways by describing Margaret's desired and brutalized flesh within the narrative proper. Among other things, the pearl is said to mitigate against the "effusion of blood," which Jacobus takes to refer to the blood baptism of martyrdom. ${ }^{58}$ The tyrant Olybrius presents an alternate etymology once she tells him her name: “...you are known to be noble and you are lovely as a pearl. ${ }^{, 59} \mathrm{He}$ concerns himself with the quality of her physical presence, caring little for her immaterial soul. The possessiveness latent in the Dreamer, whom the Pearl Maiden calls 
"no kynde jueler," is explicit in Olybrius's imperative, "Unless you yield to me, I'll have your body torn to shreds!"60 The tyrant desires to possess the small, smooth sides.

Similarly, the Dreamer's grasping attitude inhibits his ability to communicate with the Pearl Maiden. He, too, fixates on her physical presence and her availability to him. The Dreamer's first words to the Pearl Maiden repeat "pearl" compulsively, noting the pearls on her clothing as well as her own pearly quality. The Dreamer's emphasis on his own longing seeks to collapse the space between him and the Pearl Maiden, subsuming her into him. He denies her freedom by defining her as proper to him (her place is beside him), which is a short step removed from property of him (she belongs to him) ${ }^{61}$ The hyperbolic context of the "Life of Saint Margaret" provides a backdrop against which Pearl can be read as a less dramatic, more average version of the dynamic between the hagiographical stock characters of tyrant and virgin. The Dreamer is certainly not bloodthirsty; his possessiveness is not savage, but stifling. The Pearl Maiden, who "lyfed not two yer in oure thede" ("lived not two years in our land"), probably died as a toddler. ${ }^{62}$ Yet the Pearl-poet's decision to depict her soul as a mature, marriageable young woman accentuates her resemblance to the virgin martyrs, further suggesting a deliberate intertextual allusion. The context is fourteenth-century Christian England as opposed to the fourth-century pagan Near East. Still, this makes the Pearl Maiden's resemblance to the likes of Saint Margaret all the more noteworthy.

The Pearl-poet's decision to depict the 144,000 as a "prosessyoun" of pearl maidens is a deliberately striking twist on tradition. ${ }^{63}$ In Fitt XVII and Fitt XVIII, the Dreamer describes heaven by quoting and elaborating upon moments from chapters twenty-one and twenty-two of Apocalypse. These chapters describe the physical layout of the New Jerusalem. Once he has painted this picture, the Dreamer "sodanly" notices a troupe "Of such vergynes in the same gyse/ 
That was my blysful anunder croun./ And coronde wern alle of the same fasoun,/ Depaynt in perles and wedes qwyte;/ In uchones breste was bounden boun/ The blysful perle wyth gret delyt" ("Of virgins in the same guise as my lovely one, under her crown. All were crowned in the same manner, bedecked with pearls and white clothing; the blessed pearl was firmly bound on each one's breast, with great delight") ${ }^{64}$ This company consists of virgins who resemble the Pearl Maiden in their bearing and apparel. They are all similarly crowned, which suggests that these are the queens of heaven alluded to previously (VIII, IX). This is the group that the Pearl Maiden had earlier described as "maydennes an hundrethe thowsande,/ And fowre and forty thowsande mo" ("Maidens, a hundred thousand, and forty-four thousand more"). ${ }^{65}$ Yet the poem's source-text contains no mention of maidens. The 144,000 also comes from the Book of Apocalypse where it is mentioned in chapters seven and fourteen. In chapter seven, the 144,000 are the ones whose foreheads are signed in order to spare them the tribulations of the world's end. They include members from the twelve tribes of Israel as well as a great, international multitude clothed in white robes and holding palms (Apoc. 7.9). One of the ancients explains to John that, "These are they who are come out of the great tribulation, and have washed their robes, and have made them white in the blood of the Lamb" (Apoc. 7.14). Later, the same 144,000 souls are described as "they who were not defiled with women: for they are virgins...without spot" (Apoc. 14.4-5). ${ }^{66}$ Patristic and medieval commentators had many ideas about who these 144,000 were. Possibilities seemed to include martyrs, the entire church, virginal men, and virginal male martyrs. Until this point, the Dreamer has taken little license in his description of the New Jerusalem. Now, however, "The 144,000 chaste men have become pearl maidens, the static scene of the Bible has been set moving so that the crowd forms a procession, and the setting of the scene is no longer the earthly Mount Zion but the Heavenly 
City of Apocalypse 21. ${ }^{\circ 67}$ Why depict this spotless assemblage in a feminized manner? The detail that they "were not defiled by women" seems to foreclose upon the possibilities of these being female virgin martyrs — or women of any kind.

This depiction of the virgins as a company of regal maidens extends and develops the allusion prompted by the evocation of Saint Margaret. The virgin martyrs were a favorite category of saint, their tales a familiar subgenre of hagiography. The familiarity of this template of sanctity would have given readers purchase on the alien Pearl Maiden. ${ }^{68}$ The virgin martyr of hagiographical lore was both remote and ready-to-hand. ${ }^{69}$ She proved a recurrent figure in the medieval imagination, yet her particular mode of sanctity had lost its original context. Jacobus de Voragine offers four categories of saint in his entry for All Saints Day, and this taxonomy reflects popular ways of organizing the saints. The categories are apostles, martyrs, confessors, and virgins. Though both male and female saints prized virginity, the virgins were typically gendered female: "they are the brides of the eternal King." Alluding to Apocalypse, Jacobus notes that "virgins enjoy many privileges. They will have golden crowns, they alone will sing the canticle, they will wear the same garments that Christ wears, they will always march after the Lamb himself." ${ }^{, 70}$ The trial of virginity struck hagiographers as a more interesting spectacle if the virgin was a young, beautiful, and nubile girl because it raised the possibility of rape. It was especially titillating if the presence of a sexual and religious predator embodied this threat explicitly. These plot points were studiously cultivated, with accounts of older widows morphing into sensational tales of young girls. The imagery favored by hagiographical accounts of virgin martyrs as stubborn brides of Christ is visible also in spiritual writing about men. Christians had long imagined the church, and individual souls, in feminized terms. This was owing in part to early Marian theology, to commentaries on the Song of Songs, and to the feminine gender of the 
noun anima. Since the soul was imagined as the feminine Bride to Christ's Bridegroom, the 144,000 of Pearl might also be read as allegorical representations of both men and women. The text complicates this, though, by making its particular Pearl Maiden definitively female. The Dreamer, with one foot in the earthly world, understands her as female. While he notices that she appears older than when she died, he is not startled by her feminine appearance. The language of queenliness also emphasizes the femininity of these souls. This company of regal virgins resembles visual and textual representations of the virgin martyrs. I do not argue that the 144,000 maidens of Pearl are meant to be virgin martyrs; details from the poem suggest otherwise. Yet they are aesthetically identified with them, so much so that readers probably imagined this "moteles meyny" with recourse to virgin martyr iconography and lore. ${ }^{71}$

Several motifs, plot points, and character traits are most legible when read against the genre of hagiography. The crown that the maiden doffs, which receives numerous mentions, echoes the "crown of martyrdom" alluded to by the earliest martyrs and canonized by Prudentius's Peristephanon Liber. One contemporary example of the crown motif appears in Chaucer. The Pearl-poet might have been familiar with the Second Nun's Tale, a re-telling of the "Life of St. Cecilia." As a sign of their impending martyrdom, Cecilia and her husband Valerian (whom she has convinced to remain chaste) receive "Corones two" made of "roses and of lilie." "Snow white and rose reed," these crowns are identified with both their chastity and their martyrdom. ${ }^{72}$ In addition to the Pearl Maiden's crown and "snow white" garments, her royal bearing identifies her with the virgin martyr legend. The Pearl Maiden explains that Christ "toke myself to hys maryage,/ Corounde me queen in blysse." It is unclear whether any soul, or Bride, might reign as a heavenly queen, or whether only the virgins have that honor. Though all share in the plenitude of heavenly bliss, the "spotless" virgins do seem to hold a special place. Still, with 
the crown so thoroughly identified with the iconography of martyrdom, perhaps readers were meant to share the Dreamer's dismay that she is "quen mad on the fyrst day" ("made queen on the first day"). ${ }^{73}$ With the crown comes authority.

Authoritative posturing and dialectical prowess are also typical of the virgin martyr figure. In one redaction of the life of Saint Margaret, the hagiographer engages in "thesaurusstraining bursts of artistry that illustrate Margaret's spiritual power through her verbal control in the midst of her physical trials. ${ }^{.74}$ The virgin martyr is not only faithful but also articulate. ${ }^{75} \mathrm{In}$ his case against a strictly allegorical interpretation of Pearl, Spearing argues that the Pearl Maiden's exegetical responses to the Dreamer cannot be read symbolically because "the Maiden is here doing what the writers of medieval devotional works do: expounding allegory, not writing it." ${ }^{76}$ The Pearl Maiden — as a biblical exegete, dialectician, and teacher — has the striking authority of holiness. There is no better teacher of doctrine than a beatified saint. The teaching hierarchies of earth disappear since "The court of the kyndom of God alyve/ Has a property in hytself beyng" ("the court of the living God has an inherent property") by which the elevation of one does not "depryve" another. ${ }^{77}$ The Dreamer, interpreting her from an earthly standpoint, is bemused. In the midst of a blazon lauding her beauty, the narrator notes that "Her semblaunt sade for doc other erle" ("Her visage was grave enough for a doctor or earl"). ${ }^{78}$ This scholarly habitus seems to contrast with her airy splendor. The Dreamer initially balks at her authority but ultimately comes to respect it, asking her to excuse him "if I speke errour." that his responses might be considered "error" in her eyes, the Dreamer eventually yields exegetical authority to the Pearl Maiden. She does not refrain from scolding him or questioning the soundness of his judgment ("Me think thy tale unresounable"), but their dialectic remains a mild version of similar hagiographical encounters. ${ }^{80}$ 
While many virgin martyrs dole out strongly-worded chastisements to their oppressors, Saint Catherine of Alexandria serves as the exemplar par excellence of rhetorical virtuosity. Her learnedness frustrates the tyrant Maxentius so much that he summons "Fyfty men.../ Grettest clerkys and wys of lare:/ In al wisdom and eke Latyne/...For to dysspute with Kateryne."\$1 These learned men all convert and are martyred. Catherine's debate with the fifty philosophers remains iconic and may also color the exchange in Pearl. Catherine's legend contains the conventional twofold response to saintly exhortation: the individual receiving instruction will either convert or run mad (as the tyrant usually does). The Dreamer's reaction to the Pearl Maiden's dialectical instruction contains the germs of both possibilities, though with a difference. As his vision reaches a pitch, the language of madness momentarily takes over. The Dreamer describes himself as "ravyste" and "dased," certain that "No fleschly hert ne might endeure" such sights. ${ }^{82}$ This experience of ecstasy differs from the hagiographical tyrants' bloodthirsty ravings. It stems from his status as a still-living person. Yet it echoes the motif of madness seen in virgin martyr lore. In both the hagiographical tradition and Pearl, the frenzy increases asymptotically the closer one gets to the holy. In many virgin martyr legends, the tyrant's madness culminates in death. The Dreamer, too, undergoes a kind of death, leaping into the Stygian stream and getting ejected from the dream. Yet the conversion dynamic is at work as well. The Dreamer wakes with a renewed sense of patience, committing his pearl to God ("to God I hit bytaghte"). ${ }^{83}$ Nevertheless, neither potentiality (insanity or conversion) ripens into actuality. He laments that he acted before seeing more of heaven's mysteries and remains deeply ambivalent about the whole experience. The Pearl-poet, who probably had pastoral duties of his own, offers readers more realism than can be found in a traditional saint's life, refusing to make the Dreamer into a caricature. When faced with a holy apparition, the poet suggests, most 
individuals would find it dizzying and opaque. Any transformation that a saint inspires is as likely to be subtle as dramatic.

\section{Intercession}

While aesthetic evocations of the virgin martyr legends situate Pearl within a hagiographical milieu, the poem's plot structure reflects a fundamental aspect of sainthood: intercession. Pearl depicts a beatified soul "departing" from heaven to aid a still-living soul that has cried out for (or invoked) her. "Why can the dead do such great things?" Augustine asks in City of God. ${ }^{84}$ From at least the second century, Christians developed the practice of praying to their extraordinary dead—especially to the martyrs, whose deaths witnessed to an invisible reality. They "prayed for their (ordinary) dead but they prayed to the martyrs." ${ }^{15}$ A theology of patronage developed, based on the urban political dynamics of late antique Rome. Unlike worldly justice, however, "the justice of the saint was all that justice should be-it was manifest, swift, and remarkably mild." ${ }^{86}$ Posthumous miracles were as important a part of the hagiographical tradition as the saints' earthly lives and came to be gathered in books of their own. The earliest free-standing books of miracles feature Saint Stephen and Saint Thecla. ${ }^{87}$ The genre illustrates the theology of a tripartite church formed of the church militant (the living), the church suffering (the souls in purgatory), and the church triumphant (the saints in heaven). While the prayers of the living might benefit the souls in purgatory, the prayers of the saints assisted the living. The holy dead could even help the living osmotically, by virtue of mere proximity. The practice of burial ad sanctos developed because, as Maximus of Turin put it, "If we rest with the holy martyrs, we escape the shades of hell, if not by our own merits at least by holiness of association." ${ }^{88}$ The Dreamer instinctively prostrates himself ad sanctos, though he might not understand his loved one as a saint before his dream. He says of his pearl, "I leste hyr in on 
erbere;/ Thurgh gresse to grounde hit fro me yot.../ Sythen in that spote hit fro me sprange,/ Ofte haf I wayted..." ("I lost her in an arbor; it went from me through grace and to the ground... Since it sprang from me in that spot, I have often waited...") ${ }^{89} \mathrm{He}$ falls asleep on a mound that is either a symbolic or an actual grave. As a result, he receives a spiritual vision in the form of a dream. What follows could be understood as an elaborate miracle story. He receives the visitation for which he has longed, though it frustrates his expectations.

By both shifting the intercessory act to a heavenly "space" and maintaining distance between saint and supplicant, the Pearl-poet offers a more theologically precise, less mythic account of saintly intercession. This necessarily results in a more apophatic portrait of sainthood, as it renders the saint less intelligible to earthly logic. Most hagiographical accounts of intercession take place on earthly terrain. They startle and interrupt the flow of this-worldly processes, either by administering otherwise unavailable justice or providing succor. Yet these intercessory acts are usually legible on earthly terms. However saintly mediation actually functions, miracle stories imagine it as some mode of earthly presence. Hagiographical representations of intercession do for saints what beast fables do for animals. A fable anthropomorphizes non-human subjects, and a liber miraculorum imagines saints in worldly terms, however qualified. Hagiographers depict saints as behaving in ways that are fickle, playful, amorous, or even cruel. Sometimes their antics are referred to as joca-jokes. ${ }^{90}$ While their actions are arresting, they remain bound up in the emotional economy of earthly human life. In one example from Gautier de Coincy, a young gallant places his ring on a statue of the Virgin Mary, vowing to serve her. He soon forgets his promise and marries. Jealous, the Virgin appears between his wife and him in their bed, demanding that he become a celibate. ${ }^{91}$ This sort of characterization emphasizes continuity between earthly humanity and transfigured humanity, 
drawing as much on romance and fabliau as on theological precepts about sanctity. The saints are homely and relatable, at least relatively so. Pearl departs from such representations; its portrait of intercession — mediated by a dream — takes place on heavenly terrain. The Pearl Maiden seems detached, even cold. She is not susceptible to the Dreamer's emotional pleas, even if she bears him goodwill. By bringing the supplicant into the saint's territory, the Pearl-poet is able to preserve the alien, transfigured aspects of sainthood without forgoing real communion. The strangeness that hagiography bestows upon the saint's "apophatic body" explodes into its transcendent glory. ${ }^{92}$

By the time the Pearl-poet was writing, Thomas Aquinas had offered a comprehensive account of saintly intercession. He asks whether or not the saints have knowledge of living people's prayers. He proffers several reasons why it seems that they do not: it would disturb their peace, only God reads the heart, the relatives and friends of deceased saints suffer like anyone else (implying a lack of intercessory relief), and so on. Aquinas argues that, by participating in the divine essence, the saints are cognizant of all that they need to know. ${ }^{93}$ In seeing God, the saints see most clearly. They enjoy a complete vision of reality. Therefore, they must be cognizant of earthly prayers. Saints, however, are not omniscient. They need only share in the beatific vision enough to be perfectly happy. This means they see in the Logos all things that pertain to them. Cognizant, then, of individuals praying to them, what do the saints do? Nothing they are not already doing. The activity of their heavenly communion is sufficient for intercession. Their wills already coincide perfectly with God's. In heaven, knowing and doing are the same thing, because all that is truly true is all that God wills. The repose of the holy dead is not interrupted, yet they are not unaware of those who address them from the other side of death. $^{94}$ 
This placid theological portrait is reflected only darkly in the quirky, mythologized activity imagined by hagiographical accounts of posthumous intercession. The theological version proves difficult to imagine in anything other than conceptual terms. Intercession appears utterly passive; it is part and parcel of the saints' heavenly bliss. Perhaps most challenging of all, the prayers of the living do not stir the passions or evoke an emotional response. Saints are perfectly happy. ${ }^{95}$ Empathy disappears because it requires a shared experience of suffering. The dead leave this behind, and empathy is purified into a more otherworldly version of itself: complete goodwill, understood as alignment with divine will. Perhaps this sounds appealing as an eschatological final destination, but it does not make for a warm, comforting encounter. The saints have passed beyond the trials of the human heart. They have transcended heartache but, the Pearl-poet tantalizingly suggests, may seem heartless as a result. ${ }^{96}$

The Pearl Maiden puts it neatly when she says, "I am holy hysse." 97 Nothing of her being belongs to anyone but Christ. All other claims are false if not rerouted through the Lamb. She is utterly given over to him, as are all the heavenly souls. The Dreamer learns the hard lesson that his pearl is already possessed by another man, one who has purchased her, paradoxically, by giving himself to her entirely. The word "holy" possess a homonymic quality, meaning either "wholly" or "holy." The sentence could read either "I am wholly his" or "I am holy, [being] his." Both senses amount to the same thing. To belong completely to Christ is to be truly "holy," since holiness consists of participation in the divine life. Unless it is shared, the holiness of another can only be experienced "as something outside of and foreign to oneself... [perceived] as a conceptual lack, as a space where the profane cannot enter." 98 The holiness of another baffles as much as it soothes. The Pearl Maiden occupies a space the Dreamer cannot approach, and this distance causes him great anguish. A river divides the Edenic (but also purgatorial) antechamber 
to heaven from heaven proper. Before he even sees the Pearl Maiden, the Dreamer longs to cross it ("Now were I at yow byyonde thise wawes,/ I were a joyfol jueler"; "Now, if I were with you beyond the wayves, I'd be a joyful jeweler"). He cannot join her: "Bot the water was depe, I dorst not wade,/ And ever me longed ay more and more" ("But the water was deep, I dared not wade/ And yet I always and increasingly longed to do so"). ${ }^{99}$ The space between them is dangerous and impossible to traverse. She not only refrains from inviting him across, she rebukes him for even desiring to cross. This dream, which began as a comfort, immediately generates more longing. The Dreamer is an endless well of desire. David Aers points this out in his article on the insatiability of mourning and masculine desire:

Bliss has generated a new sense of lack in the dreamer even though this has definitely not been in response to any theocentric yearnings... His desire has shifted from the lost object, detached from the missing pearl on whose grave his body still lies, and reattached itself to this unknown land across the water... At this moment of newly formed desire premised on a new sense of lack, the dreamer suddenly sees [the Pearl Maiden]... With this resurgence of the old desire, inevitably, comes a double fear - the fear that 'so strange a place' may signify unknown changes and, decisively, the fear of loss, the fear that she on whom he now gazes will elude him again... ${ }^{100}$

The Dreamer's desire expands to encompass everything that remains out of his reach. For him, there is no repose here, only more pain as the heart stretches out toward an infinite good without recognizing it as such. By the end of the dream, this desire has grown into the undeniable wish: "I wolde be there." 101 Of course he jumps, which jolts him out of the dream. He wakes to find himself oppressed by “A longeyng hevy," still feeling trapped in "thys doel-doungoun."102 Though clearly not free from all vestiges of his former desire, the Dreamer has, by the poem's end, perhaps grudgingly come to a better understanding of heavenly ways. He now recognizes that part of his attraction to the Pearl Maiden was also the experience of being "drawen to Goddes present" and laments that he did not see "mo of his mysterys." ${ }^{103}$ His desire for his 
particular beloved ("my lyttel queen") has led him into the deeper waters of love for the divine. Yet the way has been painful. The Pearl Maiden refuses to offer herself as an emotional refuge. She does not pretend they are ontologically the same, nor that he should desire to join her as he is. Perhaps unlike the welcome Dante receives from Beatrice, the Pearl Maiden tries to make herself transparent before Christ. Her splendor is his splendor, yet the Dreamer, who loved her particularly, has difficulty seeing through her.

In addition to this symbolic separation, the entire encounter is plagued by communicative disconnect: she understands him, but he does not understand her. Their exchange truly is dialectical in that each response adjusts to perceived inadequacy in what has just been said. They are seldom in accord. Though the conversation does progress, the process is a painful one-for both Dreamer and reader. While the narrator can compare the Pearl Maiden's intercessory speech to "jueles," the Dreamer shows more resistance. ${ }^{104}$ He vacillates between apologetic solicitation ("To be excused I make requeste," "Rebuke me never wyth wordes felle") and reproach ("My precious perle dos me gret pyne," "Thou cowthes never God nauther plese ne pray," "Me thynk thy tale unresounable"). ${ }^{105}$ He continually questions her authority, both because his sense of hierarchy is earthly and because her statements deny him the immediate, emotional succor he desires. The Pearl Maiden does not hold back. She laces her instruction with rebuke, usually targeting the shortcomings in the Dreamer's speech and reasoning: "Though art no kynde jueler," "So madde ye be," "Ye setten hys [God's] wordes ful westernays," "Thou moste abyde."106 Even worse than this mortifying reversal of roles, however, is the distance implied by her chastisements. The Dreamer loves her desperately, even if that love is limned by possessiveness. He offers the Pearl Maiden a heart-wrenching plaint, identifying their exchange as discordant and pining for the unity that they enjoyed in life. On earth, he insists, "we wern at on" ("we were 
at one"). As if speaking to someone who has been journeying and now finds home strange, he says, "God forbade we be now wrothe,/ We meten so selden." This piteous understatement does two things. It acknowledges the extraordinary nature of their encounter (which is nothing other than saintly intervention) while lamenting its seemingly anguished quality. It is wondrous but disturbing in its strangeness. As if he speaks with a child who has left home and become more sophisticated than her rustic parents, he abases himself in an attempt to shame her into compassion: "Thagh cortaysly ye carp con,/ I am bot mol and maneres mysse" ("Though you can speak prettily, I am only dust and lack manners"). ${ }^{107}$ Her newfound eloquence disorients him, exposing the uncouthness of his own speech. This marks a turning-point for the Dreamer, who slowly comes to realize the effectiveness of addressing her as a lofty creature with greater understanding. Seeking their former unity, he adopts this rhetorical posture before fully understanding it. By the end of the poem, his paternalism has given way to the attitude of a devotee: "I yow bycalle,/...As thou art glorious" ("I call on you... As you are glorious"). 108 Mourning has assumed the hue of invocation.

Despite the distance between them, the Pearl Maiden has indeed come to the Dreamer's aid. Concerned with his salvation, she acts as a true intercessor, not simply a scold. She will not be possessed by him, but she does present herself to his sight. She deigns to be proximate to him, her words hovering over the water that divides them. This nearness "symbolizes her divinely vouchsafed role as instructor-intercessor."109 The Pearl Maiden attempts to relieve his pain, even if the medicine tastes bitter. ${ }^{110}$ His longing is for her, so she must sternly insist that nothing but heaven satisfies. This message resides at the heart of all saintly intercession. As Aquinas argues, saints are beings whose wills align perfectly with God's. The Pearl Maiden chastises the Dreamer for believing only what he can see. Now that he can "wyth yyen me se," the Dreamer is 
satisfied. ${ }^{111}$ This not only makes an idol out of the Pearl Maiden, it indicates a lack of faith. If faith is belief in things unseen, and more blessed are those who believe without seeing, then faith has a special role to play in the mourning process. The survivor must decide what to do and believe once his loved one has disappeared from view. Blessed are those who mourn, yet that basic human instinct has always pressed against Christian doctrine. Delicately deploying the third-person, the Pearl Maiden rebukes "that jueler.../ That leves oure Lorde wolde make a lye,/ That lelly hyghte your lyf to rayse..." ("that jeweler who believes our Lord would lie, who loyally promised to resurrect you"), giving the Dreamer an opportunity to denounce such doubt — to not be that hypothetical jeweler. ${ }^{112}$ Christ warns his disciples not that his death will cause them sorrow, but that soon they will not see him (John 16.16). It is the sight of an empty tomb that occasions Mary Magdalene's panic (Matt. 28.6). In the first letter to the Thessalonians, Paul exhorts the churches not to sorrow over the dead like those who do not believe in the resurrection of the body (1 Thess. 4.12-15). The Pearl Maiden, in redirecting the Dreamer's desires from herself to Christ, follows in the same tradition of seemingly callous exhortation. She sees beyond the Dreamer's sorrow to his ultimate good: "The oghte better thyselven blesse,/ And love ay God, in wele and wo" ("You would do better to bless yourself, loving God always, in joy and woe"). ${ }^{113}$ The statement contains more than a command, prefacing the advice with a promise of blessing. She does not belittle the Dreamer's sadness. Rather, she insists that he would more likely flourish if he could rest in God, believing in his promise of salvation, during times of trouble. It is a mark of the Pearl-poet's realism and pastoral sensitivity that her admonition does not inspire an instant conversion. Pearl begins and ends with sadness, though arguably moving the Dreamer from the bitterness of despair to hope-inflected lamentation. Religious consolation does not provide an easy escape from earthly realities. That the poet honors this by concluding 
the poem with a still-sorrowing, if chastened, narrator indicates his own respect for the human heart.

Festival

Finally, Pearl's liturgical evocations give it a significant hagiological context. The narrator has his dream at the beginning of autumn, a season of several festivals relevant to the poem's content. The holy days alluded to by the poem feed into its theme of apophatic sainthood. As will be seen, they emphasize the strange, transfigured reality of the church triumphant. Both in its content and in the calendrical context imagined by its frame narrative, the poem draws on liturgical readings and festival customs for Allhallowtide: the Vigil of All Saints (Oct. 31), All Saints Day (Nov. 1), All Souls Day (Nov. 2). Most likely a cleric, the Pearl-poet would have lived by the rhythm of these readings. He would have instinctively associated the Book of Apocalypse with these days celebrating the collective dead. In the Sarum Breviary, the readings for the vigil and All Saints come from Apocalypse, and the readings for All Souls address the theme of resurrection. ${ }^{114}$ There is significant overlap between the liturgical readings and Pearl's use of Apocalypse, both thematically and in the poem's actual citations. The cultural phenomena of these festivals help us to understand the poem's logic, yet few scholars have used this calendrical context as a means of understanding the poem. We might consider Pearl a literary extension of medieval cultic devotion.

If spring is the season of rebirth, fall is the season of dying — of departures and decay. When scholars address Pearl's relationship to feast days, they begin with the month suggested by the poem itself: August. The narrator gives his frame narrative an autumnal setting. He visits the precious site "In Augoste in a high seysoun, / Quen corne is corven wyth crokes kene" ("In August during a time of festival, when corn is carved with sickles keen"). ${ }^{115}$ Many have linked 
the spice-laden garden with the Edenic dream space in which the Dreamer finds himself, noting that one paradisal spot leads him into another; the Pearl-poet twists the conventional locus amoenus topos slightly by setting his narrative during fall rather than spring. ${ }^{116}$ This harvest-time context tinges the garden with the threat of mowing (corn is reaped) even as it promises transmutation (corn comes from seeds, corn becomes food). His pearl has fallen and lies buried in the earth. Despite the tantalizing spices that hint of transfiguration and rebirth (though also of burial rites and the grave), it takes the Pearl Maiden to draw the parallel between pearl and seed. She points out that heaven is her true "cofer," and if that is the case, how can the Dreamer bemoan her death? ${ }^{117}$ This fails to satisfy him because the Dreamer desires his own happiness as much as hers. The Pearl Maiden shifts focus to the inevitability of the Dreamer's own death: "Thy corse in clot mot calder keve" ("Your body must go, cold, into the earth"). ${ }^{118}$ He rejoins with a protestation of his own sorrow. Finally, toward the poem's end, the Pearl Maiden becomes more explicit. She juxtaposes the image of the Dreamer wailing over a mound of earth with the reality behind that image: her perfect enjoyment of the beatific vision. She says, "Althagh oure corses in clottes clynge,/ And ye remen for rauthe wythouten reste,/ We thurghoutly haven cnawyng;/ Of on dethe ful oure hope is drest" ("Although our bodies dissolve into the earth, and you cry for pity without resting, we have the fullness of knowing; our hope rests wholly on one death"). ${ }^{119}$ One falls into the sleep of death but wakes to perfect knowing. Autumn seems to signify the moment before all things become new. In that moment, however, all one sees is death. Yet autumn is also the moment before the hardship of winter; it is a time of abundance and festivity. The "high seysoun" probably refers to a feast day of some kind. This festive context makes the Dreamer's isolation and despair all the more striking. Bogdanos suggests either the Transfiguration (Aug. 6) or the Assumption (Aug. 15) for the poem's calendrical 
context. ${ }^{120}$ Either would provide a nice theological framework. Transfiguration would prepare both reader and Dreamer for the sea-change of beatification. The Assumption celebrates the Virgin's own crossing-over, imagined as a falling asleep (the Dormition of the Mother of God) by Eastern Christians. August inaugurates a season of festivals with which Pearl explicitly resonates. While earthly celebrations move calendrically, following the cycle of life and death, heavenly celebrations are constant and ceaseless.

Pearl provides a glimpse into heavenly festival; this allies it with the Feast of All Saints. This festival imagines saintly festivity most fully. Of all the feast days, only this one honors the communion of saints in its vast and unknowable totality. During All Saints, the church militant's celebration mirrors the church triumphant's in a deliberate, unitive way. This burst of energy, occurring on November first, acknowledges the endless festivity characterizing heaven. In his entry for All Saints, Jacobus de Voragine insists that the feast was instituted "to allow a fair exchange" (propter debitum mutuae vicissitudinis) between earth-dwellers and heaven's denizens. The saints deserve a comprehensive feast day_one that celebrates them collectively, as a body — because they constantly celebrate the sanctification of the living. He says, "The saints make festival in heaven over us, for there is joy before the angels of God and holy souls over one sinner doing penance, and so we should make a fair return by celebrating their feasts on earth." ${ }^{121}$ It is impossible to know and name every saint who ever lived and died, so a catch-all feast day is needed. All Saints insists on imagining this heavenly festival by mirroring it on earth.

Someone like the Dreamer's loved one, who died in obscurity, would enjoy the anonymous honor of such a day. Throughout most of the poem, the Pearl Maiden acts as an intercessory figure particular to the Dreamer. Her soul is proximate to his, having spent earthly life in his company. The final portion of the poem gestures beyond their intimacy toward a larger 
community: the communion of saints. Citing Apocalypse, the Pearl Maiden describes heaven as the place where the "sayntes sete," as we have already seen. ${ }^{122}$ This community of saints rejoices each time a soul is added to their number: "The mo the myryer.../In compayny gret our luf con thryf..." ("The more the merrier... Our love thrives within a large company"). ${ }^{123}$ Heaven is a merry company, whose joy increases with its numbers. Yet despite this increase, their joy is never deficient. This logic of plenitude is unique to heaven. The Pearl Maiden explains it exhaustively to the Dreamer in her exegesis of the Parable of the Vineyard (Fitt X). He cannot reconcile his sense of justice to this description of God's gratuity, at least not until his attempts to reason it out are overwhelmed by a dynamic vision of this commonality. He responds positively to the non-hierarchical structuring of heaven only when he sees its members gathered together in shared festivity. The Dreamer becomes "war of a prosessyoun" (“aware of a procession") in which the intensity of everyone's joy defies the concept of degree ("Tor to knaw the gladdest chere," "it was hard to know who had the happiest demeanor"). ${ }^{124}$ The entire procession is led by the Lamb himself. The static image in Apocalypse is reimagined as a festive event - the ultimate Corpus Christi procession. ${ }^{125}$ The Dreamer cannot help but share the participants' enthusiasm. Whereas before he contested the Pearl Maiden's right to be a queen, the sight of his "lyttel quene" celebrating with everyone else now throws him into ecstasies. ${ }^{126}$ His instinct is to join the merry company: the longed-for telos of every Christian life. His desire remains imperfect and particular yet is thoroughly reoriented. He no longer wants to bring his pearl back with him; he wants to join her. He never would have imagined that All Saints Day would apply to her. Once he understands that it does, he wants it to apply to himself as well. The frame narrative begins with the narrator's aloofness on a day of earthly festival. The dream ends with an attempt to join a heavenly festival. 
The most canonical portrait of the communion of saints is found in the Book of Apocalypse. Little wonder that the liturgical readings for All Saints and its vigil draw from this text. In the Sarum Breviary, the vigil readings include Apocalypse 5.6-12, and the All Saints readings include Apocalypse 7.2-12. The former depicts the crowds—angelic and human - that throng about the Lamb's throne. They marvel over the book with seven seals, lamenting the lack of one worthy to open it until the Lamb himself steps forward. This is the moment to which the Pearl Maiden refers when she says, "Inmydes the trone, there sayntes sete,/ The apostel John hym saw as bare,/ Lesande the boke with leves sware/ There seven syngnettes wern sette in seme" ("In the midst of the throne — where the saints sat — the apostle John saw him clear as day, opening the book with its square leaves, where seven seals gripped the seam"). ${ }^{127}$ Though the narrator quotes from Apocalypse in his description of the heavenly city, the Pearl Maiden's allusion to John proves more citational. She compares her relationship with the Lamb ("my lemman swete") with John's account, implicitly inserting herself into the saintly company surrounding his throne. ${ }^{128}$ This becomes explicit when we turn to the readings from the feast day itself.

Chapter seven of Apocalypse is one of two places referring to the 144,000 "signed" by the Lamb. The Pearl-poet zooms in on just one of these souls. Medieval readers and hearers of Pearl would have understood this biblical allusion by way of its liturgical context. In other words, Pearl cannot allude to this scriptural moment without alluding to All Saints. Indeed, Pearl seems to reimagine Apocalypse in this festive light, as "associated manuscript illustrations... [depict] a royal progress through exultant crowds of saints and angels." ${ }^{129}$ As mentioned, the Pearl-poet imagines the 144,000 as a company of spotless pearl maidens. Who were they really? In Apocalypse, they include members of the twelve tribes of Israel as well as a vast multitude of 
individuals clothed in white robes. An elder tells John, "These are they who are come out of great tribulation, and have washed their robes, and have made them white in the blood of the Lamb" (Apoc. 7.14). ${ }^{130}$ Though this seems to refer to martyrs of some kind, many patristic commentators insisted on a more universal interpretation. Caesarius of Arles suggests, "The 144,000 represent the fullness of the church. For it does not say that they washed their robes in their own blood but in the blood of the Lamb, that is, in the grace of God through Jesus Christ, our Lord." ${ }^{\prime 131}$ Bede says something similar in his commentary on Apocalypse, noting the number's symbolic quality: "By this finite number is signified the innumerable multitude of the whole church..." 132 This early emphasis on totality turned the 144,000 into the ideal symbol of the church triumphant; it included all saints. If the Pearl Maiden is one of that number, then she must explicitly be named a saint. In addition to hearing the Mass for All Saints Day, medieval devotees might also have read or heard the Golden Legend entry. Though All Saints included souls of every kind, the last type in the catalogue elaborated by Jacobus is the virgin. He quotes Jerome's praise of marriage for begetting virgins: "I gather a rose from thorns, gold from the earth, from the shell a pearl!" 133 The most commonly read text on All Saints contains mention of a pearl associated with the spotlessness of virginity. The entry bears still another thematic resemblance to Pearl. Jacobus asserts that the festival was moved to November so that devotees might have a proper feast day. ${ }^{134}$ Since harvest-time means abundance, autumnal festivals make for the best feasts. This practical explanation for the feast's date is echoed by the beginning of Pearl, which points to the paradox of abundance in the midst of death.

All Saints is bittersweet in its adjacency to All Souls. The reality of death limns its vision of transfigured triumph like a dark halo. Karl Rahner meditates on the tight connection between the holy days. For him, one ought to "regard All Saints and All Souls as connected by the fact 
that a single common meaning is to be found in both. In fact we do not know precisely where the dividing line falls between All Saints and All Souls. In the deepest sense, indeed, it is not of any great significance, and is in any case provisional." 135 To some degree, All Saints constitutes an optimistic version of All Souls. Both remain mysterious - indeterminate and open, yet finite like the symbolic 144,000. On All Souls Christians pray for the dead, and on All Saints they pray to the dead. Yet as Rahner elegantly notes, no members of the church militant can know for sure "where" exactly their beloved dead reside. The major exception, of course, being the canonized saint. She represents the hope of heaven most dramatically, as the church proclaims her blessedness with certainty. Yet her blessedness by no means excludes. This is the provisional quality of the line dividing the feast days into two. All Souls is the shadow cast by All Saints. It preserves the dignity of human mourning, but its affinity with November first imbues it with the prerogative to hope. The twinning of these holidays ensures that "the brilliance of the saints falls upon the unknown saints, and can truly bring the consolations of eternity to the heart that is willing to receive them." 136 This proves exactly the sort of consolation that the Pearl Maiden offers to the Dreamer. All Saints deliberately fosters this celebration of the anonymous saint, and so must bleed into All Souls.* Though contemporary scholars have expounded upon this insight to great effect, it is a medieval one.

Pearl's thematic resonance with the principle of unity underlying the Allhallowtide triduum is itself a powerful antecedent to Rahner's account. Both Pearl Maiden and narrator work to illumine mourning with the hope of heaven. She calls it a "mad porpose" to despair over her death, arguing, "For that thou lestes was bot a rose/ That flowred and fayled as kynde hyt gef" ("That which you lost was but a rose, which flowered and failed as was its nature"). ${ }^{137}$ It is

\footnotetext{
* The theological sameness underlying these holy days has become explicit in contemporary celebrations. Some Latin American countries celebrate the entire triduum as "the day of the dead."
} 
the nature of living things to die, but their transient loveliness should not cause despair. This ineluctable reality should not be resisted, but seen beyond. Death is a false telos; this is perhaps Christianity's central principle. Why should the Dreamer mourn his pearl when she is "in cofer so comly clente" ("perfectly fitted into a casket")? Taking up his metaphor, she likens the coffin to a jewel's precious setting, finally transcending material metaphors by revealing the true casket to be her heavenly surroundings. As mentioned previously, the Pearl Maiden intercedes in order to help the Dreamer see past her demise and, ultimately, his own. Although November first belongs to the saints, they need no intercession themselves. It makes sense, then, that on the day set aside for them, the saints would do nothing other than "come together to intercede universally for us..."138 Even the Pearl Maiden's intercessory activities associate her with All Saints Day.

One particular anecdote in the Golden Legend entry for All Saints resembles Pearl very closely. Ever scholastic, the entry consists mostly of lists and distinctions: reasons for the holiday, types of saints, and so on. It concludes with a story, however. On one particular All Saints Day, the warden of the Church of Saint Peter moves from altar to altar, petitioning all the saints. Tired from his efforts, he falls asleep and is rapt in a ghostly dream. ${ }^{139}$ He has a vision of Christ's throne surrounded by angels. "Then the Virgin of virgins came forward, wearing a gleaming diadem and followed by an innumerable multitude of virgins and the continent." A procession of saints moves past him, then all chant matins. Afterwards, an angel explains what and whom the dreamer has just seen. The angel then transports the dreamer to purgatory, showing him souls in various states of agitation. Those enjoying themselves reap the benefits of the prayers of the living. He enjoins the lowly warden to "establish after the feast of all the saints a day of commemoration for the souls of all the departed..." This anecdote provides the origin story for All Souls Day, linking the holidays in legend as well as theologically. Locating the 
origins of All Souls within All Saints illustrates their seamlessness, the provisional quality noted by Rahner. Though their states temporarily differ, the saints, the souls in purgatory, and the living are unified, members of one church. Caught up in prayers of supplication, the warden (a figure for the church) has forgotten to offer intercessory prayers himself.

Both texts seek to foster concern for the dead, purifying lamentation with devotion to heaven. Both are presented as spiritual dream visions. Both allude to the vision of Christ's throne recounted in Apocalypse. Unlike Apocalypse, both imagine the scene as a procession and insist on the Virgin's primacy as "Cortayse quen." ${ }^{140}$ Both emphasize the virginal quality of the company (mentioned in Apocalypse fourteen) and give the scene a liturgical hue ("mylde as maydenes seme at mas"). ${ }^{141}$ It is true that textual and visual depictions of the church triumphant tended to draw from Apocalypse. That alone would account for some of the commonality between Pearl and any account of All Saints. Yet the foregrounding of the Virgin, the lowliness of the dreamer, the thematic resonances, as well as the sheer popularity of the Golden Legend, all work together to suggest a direct connection. At the very least, both texts position themselves in a specifically Johannine tradition of dream vision and exploit the hagiological implications of the apostle's vision. The holidays and the texts explicating them met the emotional and spiritual needs of individuals confronting the reality of death. While the legends, traditions, and theologies surrounding these days offered comfort, a twinge of panic often lingered.

The estrangement experienced by the Dreamer is a literary representation of real anxieties inspired by the communion of saints. Despite the hope afforded by cultic devotion, medieval devotees worried that the saints' transfiguration might sever their earthly bonds. The Cistercian Bernard of Clairvaux — himself eventually canonized — was among those whose mourning process was plagued by this fear. The death of his brother Gerard was a heavy blow. In addition 
to the pain of loss, Bernard was anxious about what their heavenly reunion would entail. $\mathrm{He}$ addresses his brother in a sermon, saying, "Your love has not been diminished but only changed..."142 He believes that all things are made new in heaven but wonders what effect this will have on a soul's earthly loves. Sorrow gives salt to wisdom, and other meditations on his loss resemble the Dreamer's attitude. "Gerard was mine, so utterly mine," he insists, describing him as "snatched" and "torn" from him. He imagines his brother's death as a species of robbery, as though a precious belonging had been stolen from him, personally. ${ }^{143}$ Though immersed in the monastic devotion to heaven, Bernard mourned as keenly as any layperson. His personal experience affords an interesting case study of the intersection of All Saints and All Souls. It highlights the realism and relatability of the Dreamer's psychological state.

Much of Bernard's theorizing about the afterlife occurs in his sermons for All Saints Day. Anna Harrison has explored Bernard's grief for Gerard in the context of these sermons. She notes that Bernard imagines heaven as a place of repose and of feasting. Despite the grief attested in other documents, he does not imagine heaven as a place of "soul-to-soul" interactions. Rather, all feast on Christ, eyes trained on him. They share each other's company, but only because they share Christ. ${ }^{144}$ Bernard anticipates Thomas Aquinas's theory of intercession by describing the saints as totally absorbed into the will of God: “...to lose yourself in a certain manner, just as if you were not you... and to empty your very self, and to be almost annihilated (paene annullari), is of heavenly life not of a human state..."145 This abstract description of heaven differs from the way in which saints' lives imagine intercession. The pure intentionality of the soul toward God resembles a kind of annihilation. Theologians struggled to hold the continuity and disruption of something like the self in tension. Yet the issue cannot remain speculative for Bernard, who has experienced loss. Saints keep their memories. He insists on 
this. They do not forget those whom they have loved. If they forgot, then how could they give welcome? ${ }^{146}$ Both Bernard and Rahner insist that "we have the right to hope that we can find all those whom our hearts have loved" among the saints. ${ }^{147}$ Bernard frets about the nature of his relationship with Gerard and how heaven will change it. While he experiences alienness as a possibility, he rejects it as a reality. On this side of heaven, our emotional experience of the idea of heavenly communion is one of dispossession, loss, and alienation. This is the phenomenon that Pearl explores, inserting a living person into the afterlife. The Pearl Maiden insists, though, that the truth exceeds what the Dreamer can fully understand in his earthly state. Ultimately, one must take on faith the fact that all of this change transforms souls into their truest forms. Bernard contrasts the experience of this truth with the truth itself:

Does the heavenly habitation harden the souls that it admits, or deprive [them] of memory, or strip away kindness? Brothers, the breadth of heaven dilates, not contracts, the heart; it delights, not estranges (alienat) the mind; it enlarges, not tightens (contrabit) the affections (affectiones). In the light of God, memory is made clear not obscured; in the light of God, that which is unknown is learned, that which is known is not unlearned. ${ }^{148}$

Bernard focuses on the question of the heavenly soul's continuity with its earthly existence. This problem is refracted through the question of the glorified soul's capacity for relationality.

Memory becomes the lynchpin to Bernard's assertion that human relationality continues to exist in heaven, however transfigured. Aquinas's account resembles Bernard's in its insistence on both the soul's utter focus on God and its ability to be in relation with the living. Both dissolution into the will of God and affection for those it has loved characterize the soul, and simultaneously. If Bernard needed to argue against the saints' alienation from the living — if he spent All Saints preaching on the saints' care for the living - then clearly others (even his fellow Cistercians) needed convincing. As pastoral documents, sermons provide instruction and consolation to their listeners and readers. Even if Bernard's longer sermons were meant only to be read, they still 
addressed what he saw as a pressing concern. Pearl is a pastoral text as well, one exhibiting concern, respect, encouragement, and correction for people like the hapless Dreamer, a sort of Everyman.

The Dreamer experiences the same anxieties as Bernard, vacillating between alienation and familiarity throughout the entire poem. The Pearl-poet invests the Dreamer's first sight of the Pearl Maiden with an ambivalence that haunts the entire encounter. His recognition of her is gradual and cautious ("On lenghe I loked to hyr there;/ The lenger, I knew hyr more and more," "I looked upon her for a long time. The longer I looked, the more I knew her"), not dramatic and joyful. ${ }^{149}$ For all this, though, it is certain (“I knew hyr wel”). ${ }^{150}$ Though he feasts on her splendor with his gaze, registering a real connection, the reunion comes as a shock. He refrains from calling to her because "baysment gef myn hert a brunt;/ I sey hyr in so strange a place,/ Such a burre might make myn herte blunt" ("astonishment gave my heart a blow. I saw her in such a strange place... Such a blow might well stop my heart"). ${ }^{151}$ Everything in the dream is spiritual and, thus, non-representable. The poet tries to convey this by imbuing the encounter with cognitive dissonance. Or, rather than dissonance, a hyper-polyvalency. (She is an infant and a maiden, a pearl and a person, his relative and a bride of Christ.) Something seems familiar, yet the maiden's ethereal appearance and surroundings render her identity indeterminate. At least, this is how the still-living Dreamer experiences her. He translates this spiritual experience into a physiological one: the apparition is wreaking havoc on his cardiovascular system. The overlay of alien onto familiar powers the entire dialectic. The Pearl-poet himself introduces the word "strange," and one might consider the entire poem as variations on the theme of strangeness. Yet as Pearl Maiden, poet, and perhaps even narrator insist, these "mysterys" that disturb the living are the joys of the saints. ${ }^{152}$ As long as the Dreamer attempts to conform the Pearl Maiden to his 
memories and ideas of her, he denies her the splendor of her transfiguration. Her truest self is not to be possessed by him, but by Christ. And this Christic possession differs in kind: possession by Christ is inseparable from possession of Christ, who gives himself in love. Pushing against the Dreamer's romantic rhetoric, she insists “The Lambes vyves in blysse we bene” ("The Lamb's wives in bliss we are"). ${ }^{153}$ To be a saint is to recognize one's purchase by Christ, a state of being that is most fully comprehended and enjoyed in heaven. To see a saint is to recognize this fact; to see and seek Christ first. The saints are most fully conformed to him, so they can only be understood through his form. ${ }^{154}$

Hagiological art is filled with attempts to capture the strangeness of their subject matter. Nicolas of Lyra says that "the refreshment of the saints is not understood by us, unless by a corporeal image." 155 Yet how qualified an image! Bogdanos calls the poem an "imagistic conceit of eternity," comparing it to another genre of image purporting to depict eternal realities: the icon. He says, "As the dreamer and we with him seek to enter this realm with our perception and thus to possess it, it freezes into an icon, a perfect artifice of ideality... an impenetrable, enigmatic image [of] the mystery that we are after." ${ }^{\prime 156} \mathrm{He}$ also describes the maiden as a "precious effigy" and a "frozen image of hieratic ideality." 157 Reference to this other sacred art form is useful. The stylized, abstracted, and formulaic depiction of saintly figures preserved their otherworldliness while insisting that they remained present to the living. Icons were imagined as doorways to heaven, images that opened onto a transfigured reality. Sketched in charcoal, the Dreamer has wandered into the bright planes of an icon. The paradox of the icon is that its surrealism gestures not toward unreality, but toward reality's essence. Yet the holy is experienced as a cognitive gap, as an alienness just outside our perceptual ken. Converting it into a perceivable image, then, requires an artistry as indeterminate and baffling as it is glorious. 


\section{Conclusion}

Pearl was read and written within a context of cultic devotion. This hagiological context sheds light on the nature of its apophaticism. When medieval thinkers pondered their relationship to the holy dead - to heaven - they confronted the doctrine of the communion of saints. The church triumphant, church suffering, and church militant were mysteriously united in Christ, yet the difference in states problematized attempts to think through that relationality. Heaven's denizens see God face-to-face, but the living can only peer through a glass darkly. How, then, can the living see the saints through that dark glass? The Pearl-poet takes this perspectival difference seriously. He chooses to imagine the beatific clarity indirectly, through the Dreamer's marginal point-of-view. (What would it mean, after all, to recount the "silent lauds" of heaven itself in words? $)^{158}$ The Pearl Maiden's own seeing comes to us only through her intercessory interactions with one who has invoked, or called upon, her. Beatitude is the goal of every Christian, yet its ultimate reality defies imagination. We may narrate the lives of the saints, but the afterlives prove a bit trickier.

Pearl is not about the radical disjunction between God and humanity, heaven and earth. It is about a continuity that cannot be seen through to the end. Saints are Other, but not wholly Other. Their alterity invites rather than repels. Saints' lives work to inscribe this transcendence into their narratives, so that the otherwise incarnational genre contains moments of opacity, indeterminacy, unknowing, and invisibility. This saintly apophasis conveys the otherworldly in negative terms. It is what heaven looks like from a this-worldly perspective. If sanctity is participation in the divine life — perfected only in death — it makes sense that saintly persons would share in God's inscrutability. 
Yet this experience of unknowing always contains the invitation to change one's life. It is always intercessory. One can either inhabit or resist the mysteries. By the end of Pearl, the Dreamer, who has found the Pearl Maiden so alienating, confesses that he has actually been "drawen to Goddes present" ("drawn into God's presence"). If he had reformed his desire in accordance with the Pearl Maiden's instruction, he might have experienced "mo [more] of his mysterys." 159 As far as late antique and medieval theologians were concerned, the saints were entirely pro nobis, conjoined with God's will for the salvation of souls. They willed the living toward greater holiness, but this procession into the divine life was in part experienced as darkness. The "learner's dilemma" of Plato affords a nice analogy for the process of sanctification. How can one learn anything that one does not already know? What is the moment when the unknown thing becomes known? Similarly, holiness exceeds perception, yet the more it is shared, the more it is known. This seems tautological. At what point does the devotee see or understand it enough to participate in it? Something about the tension between knowing and unknowing, familiarity and strangeness, enables sanctification. The dialectic is not interminable, however. The Pearl Maiden suggests that the darkness of ignorance must give way to faith, a provisional unknowing purified by the alignment of one's will with Christ's. This perfects the soul in charity, a progression visible in the Dreamer's movement from possessive desire to celebration of the Pearl Maiden's queenliness.

In one sense, sanctification is the perfection of a soul in charity. The cult of the saints provides context within which to understand a paradox central to Pearl: the tension between particular and universal love. On the one hand, devotees show loyalty to individual patrons, just as we love our families more than we love strangers. This is natural but perhaps not supernatural. One scholar suggests that All Saints Day was instituted in order to combat this devotional 
tribalism. Medieval devotees "were perhaps too attached to the singular relation of devotion to one saint, one protector or patron." ${ }^{\prime 160}$ All Saints reminded them that all were one in Christ. It encouraged celebrants to adopt a heavenly perspective, one that saw the entire body as well as individual members. The poem's governing image moves both readers and Dreamer toward this principle of unity. The pearl conveys particularity with great effectiveness. It is small, discrete, particular in the sense of being particle-like. Pearls are precious in their individuality; just one is worth a lot of money. We speak of singular, instantiated pearls, less often of pearl as a continuous substance. The Dreamer understands the Pearl Maiden in this way, as his particular beloved, affiliated with him because her life was proximate to his own. Seeing her in a heavenly context, however, the Dreamer must confront her by means of a different mode of relationality. Christ does not love only those with whom he passed his days. He loves universally while maintaining the particular. The beatific vision, conjoining souls with God's own will, imbues saints with this transcendent capacity for love. In heaven, the particular is not extinguished (individual souls do not collapse and merge into one pool of soul-stuff) but is purified. The pearl of great price is the kingdom of heaven, where all souls share in Christ, whose complete and utter gratuity frees them from competition. The pearl maidens each wear numerous pearls, including one large, emblematic one. The sheer multiplication of pearls would be enough to nullify a desire to possess any one of them. Unlike earthly inflation, heavenly inflation does not decrease the pearls' value. The poem goes even further than this plenitude in order to illustrate the saints' unity. It draws from a perplexing moment in Apocalypse twenty-one. Citing John, the Dreamer describes the gates of paradise: "uch yate of a margyrye,/ A parfyt perle" ("each gate of a pearl, a perfect pearl"). ${ }^{161}$ The grammar seems confused. It describes individual gates that seem to each have a pearl but, in fact, all share a single, miraculously pluralized pearl. ${ }^{162}$ The Latin is, 
et singulae portae erant ex singulis margaritis, translated in the Douay Rheims version as, "and every several gate was of one several pearl." ${ }^{163}$ Commentators noticed this. Victorinus of Pettau reads this grammar as a deliberate illustration of the unity enjoyed in Christ:

It is one thing to speak of each of the pearls; it is another thing to speak of the one pearl from which they come. For when it speaks of each pearl, it is shown that in each pearl one pearl is shining forth and that this one pearl is our Lord Jesus Christ. ${ }^{164}$

All the pearls comprising heaven, then, are co-identifiable with the pearl: Christ. "Abide in me," he says to his disciples (John 15.4). All can follow this command, but it is perfected in heaven.

The communion of saints helps the living cultivate this universal charity. Devotion to the saints assists in purifying one's love, especially during the feast of All Saints. The saints are definitive members of Christ's body, and love of saints unites the church militant with that body. Far from being a distracting and peripheral aspect of Christianity, "The unity with Christ achieved in love of the saints is rather something that is explicit and definitively complete and is the object of faith." 165 It affirms Christ by identifying the church with his body. Should the Dreamer venerate the Pearl Maiden as a saint (having been assured of her heavenly status), such behavior would not exclude his particular love. For invocation is nothing other than "the courage of that love that utters a 'thou' that extends beyond all death, and the courage to believe that noone lives alone." ${ }^{166}$ Devotion to the saints preserves the impulse inherent in mourning but transfigures it with hope. It allows devotees to see beyond the grave. The Pearl-poet represents the Dreamer's loved one in saintly trappings in order to get at this truth. At the end of the poem, the Dreamer understands divinity in increasingly familiar terms: "A God, a Lorde, a frende ful fyin" ("A God, a Lord, a fine friend"). ${ }^{167}$ The friends of God extend this friendship to all. Little wonder that saints are both strange and homely: in befriending a saint, one befriends God. Pearl reminds readers not to remain parochial in their devotions. All Saints and All Souls intersect, and 
every act of mourning should be illumined by something like cultic devotion. The poem's exultation of this anonymous girl insists we remember "those nameless saints who are consecrated in silence and upon the private altars of our own hearts." ${ }^{.168}$ Many saints remain invisible simply because human life is finite, circumscribed by place and time. The unknown saint, too, intercedes.

\section{Notes}

${ }^{1}$ Nicolas of Lyra, Nicholas of Lyra's Apocalypse Commentary, trans. Philip D. W. Krey, TEAMS (Kalamazoo: Medieval Institute Publications, 1997) 231.

${ }^{2}$ William Shakespeare, The Tempest, ed. David Lindley (Cambridge: Cambridge University Press, 2013) 122.

${ }^{3}$ Sir Gawain and the Green Knight, Pearl, Cleanness, Patience, ed. J. J. Anderson (London: Orion Publishing Group, 2005) 32 (line 835).

${ }^{4}$ Thomas Aquinas, Summa Theologica, trans. Fathers of the Dominican Province, vol. 3 (New York: Benziger Brothers, 1948) 2959. Supplementum Tertiae Partis, Q. 92, Art. 1.

${ }^{5}$ David Matzko McCarthy, Sharing God's Good Company: A Theology of the Communion of Saints (Grand Rapids, MI: William B. Erdmans Publishing Company, 2012) 27.

${ }^{6}$ Patricia Cox Miller, "Subtle Embodiments: Imagining the Holy in Late Antiquity," Apophatic Bodies: Infinity, Ethics, and Incarnation, Transdisciplinary Theological Colloquium 6, ed. Catherine Keller and Christopher Boesel (New York: Fordham University Press, 2009) 47, 58.

${ }^{7}$ Jean-Luc Marion, “The Invisibility of the Saint," Saints: Faith Without Borders, ed. Françoise Meltzer and Jaś Elsner (Chicago: University of Chicago Press, 2009) 355. 
${ }^{8}$ Petra Turner, “The Unknown Saint: Reflections on Jean-Luc Marion's Understanding of Holiness," The Postmodern Saints of France: Refiguring 'the Holy' in Contemporary French Philosophy, ed. Colby Dickinson (London: Bloomsbury T\&T Clark, 2013) 239, 233.

${ }^{9}$ Peter Brown, The Cult of the Saints: Its Rise and Function in Latin Christianity (Chicago: University of Chicago Press, 1981) 86-105.

${ }^{10}$ Victor Turner and Edith Turner, Image and Pilgrimage in Christian Culture (New York: Columbia Press, 1978) 15. (Quoted in Brown, Cult of the Saints 87).

${ }^{11}$ Pseudo-Dionysius, "The Mystical Theology" in Pseudo-Dionysius: The Complete Works, trans. Colm Luibheid (New York: Paulist Press, 1987) 136.

12 Pseudo-Dionysius, "The Mystical Theology": "But my argument now rises from what is below up to the transcendent, and the more it climbs, the more language falters, and when it has passed up and beyond the ascent, it will turn silent completely, since it will finally be at one with him who is indescribable" (139).

${ }^{13}$ Jean Leclercq, O.S.B., The Love of Learning and the Desire for God: A Study of Monastic Culture (New York: Fordham University Press, 1982) 53-68.

${ }^{14}$ The Cloud of Unknowing, TEAMS series, ed. Patrick J. Gallacher (Kalamazoo: Medieval Institute Publications, 1997) 36.

${ }^{15}$ The Holy Bible, Douay Rheims Version. Revised by Bishop Richard Challoner. Rockford, Illinois: Tan Books and Publishers, 2000: “And they heard a great voice from heaven, saying to them: Come up hither. And they went up to heaven in a cloud: and their enemies saw them" (Apoc. 11.12).

${ }^{16}$ Anderson 9 (lines 223-4). 
${ }^{17}$ In his translation of the poem, J. J. Anderson suggests the wonderful expression "utterly eclipsed," building on the poem's lunar motif. Anderson 9 (note for line 223).

${ }^{18}$ Pseudo-Dionysius, "The Mystical Theology” 138.

${ }^{19}$ A. C. Spearing, Medieval Dream-Poetry (Cambridge: Cambridge University Press, 1976): Spearing describes the gemlike qualities of the poem's form. "Pearl, indeed, is perhaps the most completely self-enclosed of all medieval dream-poems: the most perfect artistry, pearllike in its circularity of structure, so 'smothe' that its surface gives no purchase for any attempt to lever apart the real and the imagined" (120).

${ }^{20}$ Spearing, Medieval Dream-Poetry 116.

${ }^{21}$ Quoted in Spearing, Medieval Dream-Poetry 116.

${ }^{22}$ Spearing 117.

${ }^{23}$ Anderson 30 (line 790).

${ }^{24}$ See Amy Hollywood, Sensible Ecstasy: Mysticism, Sexual Difference, and the Demands of History (Chicago: University of Chicago Press, 2002) 9.

${ }^{25}$ Anderson 3 (line 61).

${ }^{26}$ A. C. Spearing, The Gawain-Poet: A Critical Study (Cambridge: Cambridge University Press, 1976) 109.

${ }^{27}$ Anderson 41 (line 1085).

${ }^{28}$ Ann Chalmers Watts, "Pearl, Inexpressibility, and Poems of Human Loss," PMLA 99 (1984): 26.

${ }^{29}$ David Aers, “The Self Mourning: Reflections on Pearl," Speculum 68 (1993): 56. 
${ }^{30}$ Anne Howland Schotter, "Vernacular Style and the Word of God: The Incarnation Art of Pearl," Ineffability: Naming the Unnamable from Dante to Beckett, ed. Peter S. Hawkins and Anne Howland Schotter (New York: AMS Press, 1984) 25.

${ }^{31}$ Anderson 2 (line 37).

${ }^{32}$ Anderson 12 (line 296).

${ }^{33}$ Anderson 10 (line 252).

${ }^{34}$ Anderson 11 (lines 256-7).

${ }^{35}$ For example: "And one of the ancients answered, and said to me: These that are clothed in white robes, who are they? and whence came they? And I said to him: My Lord, thou knowest. And he said to me: These are they who are come out of the great tribulation..." (Apoc.

\subsection{3-14) Douay Rheims Version.}

${ }^{36}$ Anderson 40 (line 1053).

${ }^{37}$ Peter S. Hawkins, "Dante's Paradiso and the Dialectic of Ineffability," in Hawkins and Schotter, eds., Ineffability: Naming the Unnamable from Dante to Beckett 9.

${ }^{38}$ Anderson 31 (line 803).

${ }^{39}$ Anderson 12 (lines 291-4).

${ }^{40}$ Jean-François Lyotard, The Confession of Augustine, trans. Richard Beardsworth (Stanford: Stanford University Press, 2000): “There emanates from the super-celestial numbers that people it a continual hymn of praise to you: unheard-of canticles, silence...speech is noise after the silence of the lauds" $(41,43)$.

${ }^{41}$ J. Allan Mitchell, "The Middle English Pearl: Figuring the Unfigurable," The Chaucer Review 35 (2000): 86-109. 
${ }^{42}$ Barbara Newman, "The Artifice of Eternity: Speaking of Heaven in Three Medieval Poems," Religion \& Literature 37 (2005): 1-24.

${ }^{43}$ Mitchell, "The Middle English Pearl: Figuring the Unfigurable" 88.

${ }^{44}$ Mitchell, "The Middle English Pearl: Figuring the Unfigurable" 93.

${ }^{45}$ Piotr Spyra, The Epistemological Perspective of the Pearl-Poet (Surrey: Ashgate, 2014) 91 .

${ }^{46}$ Anderson 10 (lines 236-8).

${ }^{47}$ Anderson 10 (line 235).

${ }^{48}$ Spearing, The Gawain-Poet 166.

${ }^{49}$ Theodore Bogdanos, "Pearl": Image of the Ineffable: A Study in Medieval Poetic Symbolism (University Park: Pennsylvania State Press, 1983) 34.

${ }^{50}$ Bogdanos 6.

${ }^{51}$ James W. Earl, "Saint Margaret and the Pearl Maiden," Modern Philology 7 (1972): 18.

${ }^{52}$ Anderson 9 (lines 199, 206).

${ }^{53}$ Wendy R. Larson, “Three Thirteenth-Century Lives of St. Margaret of Antioch,” Medieval Hagiography: An Anthology, ed. Thomas Head (New York: Routledge, 2000) 675-6. ${ }^{54}$ Earl 5-6.

${ }^{55}$ Jacobus de Voragine, "Saint Margaret," The Golden Legend, trans. William Granger Ryan (Princeton: Princeton University Press, 2012) 368; Jacobus A Voragine, “De sancta Margareta," Legenda aurea, ed. T. Graesse (Osnabrück: Otto Zeller Verlag, 1969) 400.

${ }^{56}$ Anderson 8 (line 190).

${ }^{57}$ Spearing, The Gawain-Poet 138-9. 
${ }^{58}$ Jacobus de Voragine, The Golden Legend 368; Jacobus A Voragine, Legenda aurea 400.

${ }^{59}$ Jacobus de Voragine, The Golden Legend 368.

${ }^{60}$ Anderson 11 (line 276); Jacobus de Voragine, The Golden Legend 369.

${ }^{61}$ See Helen Barr, “Pearl, or 'The Jeweller's Tale,"” Medium Aevum 69 (2000).

${ }^{62}$ Anderson 19 (line 483).

${ }^{63}$ Anderson 42 (line 1096).

${ }^{64}$ Anderson 42 (lines 1099-1104).

${ }^{65}$ Anderson 33 (lines 869-70).

${ }^{66}$ Douay Rheims Version.

${ }^{67}$ Rosalind Field, “The Heavenly Jerusalem in Pearl," The Modern Language Review 81 (1986): 10 .

${ }^{68}$ J. Allan Mitchell, Becoming Human: The Matter of the Medieval Child (Minneapolis: University of Minnesota Press, 2014): Mitchell goes so far as to argue that the Pearl Maiden exceeds the category of "human." "A most sensational case is the Middle English Pearl, an anonymous poem about a deceased infant girl who returns in a vision from beyond the grave. A radiant messianic figure, the dead infant becomes transhuman partly in virtue of the fact that she is such a meager, immature being" (7).

${ }^{69}$ For the remoteness of the virgin martyrs and their mode of sanctity to late medieval Christians, see: Catherine Sanok, Her Life Historical: Exemplarity and Female Saints' Lives in Late Medieval England (Philadelphia: University of Pennsylvania Press, 2007).

${ }^{70}$ Jacobus de Voragine, The Golden Legend 661, 665.

${ }^{71}$ Anderson 34 (line 899). 
${ }^{72}$ Geoffrey Chaucer, “The Second Nun's Tale,” The Riverside Chaucer, ed. Larry D. Benson (Boston: Houghton Mifflin Company, 1987) 265.

${ }^{73}$ Anderson 19 (line 486).

${ }^{74}$ Wendy Larson, Medieval Hagiography: An Anthology 679.

75 See Maud Burnett McInerney, Eloquent Virgins from Thecla to Joan of Arc (New York: Palgrave Macmillan, 2003); Ed. Kathleen Coyne Kelly and Marina Leslie, Menacing Virgins: Representing Virginity in the Middle Ages and Renaissance (Newark: University of Delaware Press, 1999).

${ }^{76}$ Spearing, The Gawain-Poet 131.

${ }^{77}$ Anderson 18 (lines 445-6, 449).

${ }^{78}$ Anderson 9 (line 211).

${ }^{79}$ Anderson 17 (line 422).

${ }^{80}$ Anderson 23 (line 590).

${ }^{81}$ Middle English Legends of Women Saints, TEAMS series, ed. Sherry L. Reames (Kalamazoo: Medieval Institute Publications, 2003) 180.

${ }^{82}$ Anderson 41 (lines 1082, 1085, 1088).

${ }^{83}$ Anderson 46 (line 1207).

${ }^{84}$ Robert Bartlett, Why Can the Dead Do Such Great Things? Saints and Worshippers from the Martyrs to the Reformation (Princeton: Princeton University Press, 2013) 3.

${ }^{85}$ Bartlett 3. (Quoting Augustine).

${ }^{86}$ Brown, The Cult of the Saints 112.

${ }^{87}$ Bartlett 558.

${ }^{88}$ Quoted in Bartlett 625. 
${ }^{89}$ Anderson 1 (lines 9-10, 13-14).

${ }^{90}$ See Kathleen Ashley and Pamela Sheingorn, Writing Faith: Text, Sign, and History in the Miracles of Sainte Foy (Chicago: University of Chicago Press, 1999) 32-39.

${ }^{91}$ As cited in Michael Camille, The Gothic Idol: Ideology and Image-making in Medieval Art (Cambridge: Cambridge University Press, 1989) 237.

${ }^{92}$ Miller, "Subtle Embodiments" in Boesel and Keller, eds., Apophatic Bodies: Negative Theology, Incarnation, and Relationality 45-58.

93 Benziger 2960-2961. ST Supplementum, Q. 72, Art. 1.

${ }^{94}$ Benziger 2960-2961. ST Supplementum, Q. 72, Art. 1.

${ }^{95}$ Benziger 2970. ST Supplementum, Q. 93, Art. 1.

96 Ad Putter, An Introduction to the Gawain-Poet (London: Longman, 1996): "It is so customary for medieval writers to regard this 'brainwashing' of the dead as a great blessing that it may not have occurred to us, before reading Pearl, how awful their altered consciousness can be. The moment that this becomes clear to the Dreamer is when he first exchanges words with the maiden he has missed so much. Seeing her happiness, he is upset by the fact that the pain of separation is not mutual. But the Pearl-maiden has yet another surprise in store for him, for she replies to his cry for commiseration without a trace of sympathy, as if he were a perfect stranger...” (185).

${ }^{97}$ Anderson 16 (line 418).

${ }^{98}$ Turner 235.

${ }^{99}$ Anderson 6 (lines 143-4).

100 Aers 60.

${ }^{101}$ Anderson 44 (line 1155). 
${ }^{102}$ Anderson 45 (lines 1180, 1187).

${ }^{103}$ Anderson 45 (lines 1193-4).

${ }^{104}$ Anderson 11 (line 278).

${ }^{105}$ Anderson 11, 15, 13, 19, 23 (lines 281, 367, 330, 484, 590).

${ }^{106}$ Anderson 11, 12, 14 (lines 276, 290, 307, 348).

${ }^{107}$ Anderson 15 (lines 278-82).

${ }^{108}$ Anderson 35 (lines 913, 915).

${ }^{109}$ Marie Borroff, Traditions and Renewals: Chaucer, the Gawain-Poet, and Beyond

(New Haven: Yale University Press, 2003) 119.

${ }^{110}$ Aers links the Dreamer's mourning process to the rhetoric of courtly love: "In this familiar courtly language the lost object fulfills the traditional feminine role of nurturing life source; she is the man's essential physician without whom his life becomes a disease, a nightmare of emptiness and tormented dreams..." (57).

${ }^{111}$ Anderson 12 (line 296).

${ }^{112}$ Anderson 12 (lines 301, 304-5).

${ }^{113}$ Anderson 14 (lines 341-2).

114 The Sarum Missal, ed. J. Wickham Legg (Oxford: Clarendon Press, 1969).

${ }^{115}$ Anderson 2 (lines 39-40). I follow Anderson, who glosses "high seysoun" as "festival time."

${ }^{116}$ Spearing, Medieval Dream-Poetry 113.

${ }^{117}$ Anderson 11 (lines 258-60): "To say your perle is al awaye,/ That is in cofer so comly clente, / As in this gardyn gracios gaye."

${ }^{118}$ Anderson 13 (line 320). 
${ }^{119}$ Anderson 33 (lines 857-60).

${ }^{120}$ Bogdanos 27.

${ }^{121}$ Jacobus de Voragine, The Golden Legend 660. (Latin from Jacobus a Voragine, Legenda aurea 720).

${ }^{122}$ Anderson 32 (line 835).

${ }^{123}$ Anderson 32-3 (lines 850-1).

${ }^{124}$ Anderson 42 (lines 1096, 1109). I borrow Anderson's translation for line 1109.

${ }^{125}$ Field 10.

${ }^{126}$ Anderson 43 (line 1147).

${ }^{127}$ Anderson 32 (lines 835-8).

${ }^{128}$ Anderson 32 (line 829).

${ }^{129}$ Field 10.

${ }^{130}$ Douay Rheims Version.

${ }^{131}$ Caesarius of Arles, Ancient Christian Texts: Latin Commentaries on Revelation, Victorinus of Petovium, Apringius of Beja, Caesarius of Arles, and Bede the Venerable, ed. and trans. William C. Weinrich (Downers Grove, Illinois: IVP Academic, 2011) 75.

${ }^{132}$ Bede, Ancient Christian Texts 135.

${ }^{133}$ Jacobus de Voragine, The Golden Legend 665.

134 Jacobus de Voragine 659.

${ }^{135}$ Karl Rahner, Theological Investigations, trans. David Bourke, vol. 8 (New York: The Seabury Press, 1977) 24.

${ }^{136}$ Rahner 28.

${ }^{137}$ Anderson 11 (lines 267, 269-70).

${ }^{138}$ Jacobus de Voragine, The Golden Legend 665. 
${ }^{139}$ Jacobus a Voragine, Legenda aurea 727.

${ }^{140}$ Anderson 17 (line 433).

${ }^{141}$ Anderson 42 (line 1115).

${ }^{142}$ Anna Harrison, “Community Among the Saintly Dead: Bernard of Clairvaux's Sermons for the Feast of All Saints," Last Things: Death \& The Apocalypse in the Middle Ages, ed. Caroline Walker Bynum and Paul Freedman (Philadelphia: University of Pennsylvania Press, 2000) 193; See Bernard of Clairvaux, Sermones in festivitate Omnium Sanctorum 1-5, in Sancti Bernardi opera, ed. Jean Leclercq, C. H. Talbot, and H. M. Rochais (Rome: Editiones Cistercienses, 1957-77).

${ }^{143}$ Harrison 197.

${ }^{144}$ Harrison 194.

${ }^{145}$ Harrison 195.

${ }^{146}$ Harrison 197.

${ }^{147}$ Rahner 25.

${ }^{148}$ Harrison 199.

${ }^{149}$ Anderson 7 (lines 167-8).

${ }^{150}$ Anderson 7 (line 164).

151 Anderson 8 (lines 174-6).

152 Anderson 45 (line 1194).

${ }^{153}$ Anderson 30 (line 785).

${ }^{154}$ Marion, "The Invisibility of the Saint," in Elsner and Meltzer, eds., Saints: Faith Without Borders: Quoting Pascal, Marion says that "the saints 'are seen of God and the angels, 
and not of the body nor of the curious mind. God is enough for them.' Saints remain invisible to that which does not belong to holiness" (362).

${ }^{155}$ Nicolas of Lyra 231.

${ }^{156}$ Bogdanos 4.

${ }^{157}$ Bogdanos 72.

${ }^{158}$ Lyotard 43.

${ }^{159}$ Anderson 45 (lines 1193-4).

${ }^{160}$ Jacques Le Goff, In Search of Sacred Time: Jacobus de Voragine and the "Golden Legend," trans. Lydia G. Cochrane (Princeton: Princeton University Press, 2014) 26-7. Quoting Alain Boureau and his co-editors: Jacques de Voragine, La Légende dorée, ed. Alain Boreau et al. (Paris: Gallimard, 2004) 1437. Le Goff refutes this interpretation.

${ }^{161}$ Anderson 39 (lines 1037-8).

${ }^{162}$ Fr. Bruno Shah, O.P. drew my attention to this. See our co-written commentary: Bruno M. Shah, O.P. and Beth Sutherland, "Theoretical Lunacy: a Commentary on Fitt XVIII of Pearl," Glossator 9 (2015): 355-379. <https://glossator.org/>

${ }^{163}$ Biblia Sacra Vulgata, Roger Gryson, ed. (Stuttgart: Deutsche Bibelgesellschaft, 1994). Translation from Douay Rheims Version.

${ }^{164}$ Victorinus of Pettau, Ancient Christian Texts 58.

${ }^{165}$ Rahner 21.

${ }^{166}$ Rahner 23.

${ }^{167}$ Anderson 46 (line 1204).

${ }^{168}$ Rahner 26. 


\section{Works Cited}

Primary Sources

Abelard, Peter. "Exposition of the Epistle to the Romans." A Scholastic Miscellany: Anselm to Ockham. Trans. and Ed. Eugene Fairweather. New York: Macmillan, 1970. Print.

Aquinas, Thomas. Summa Theologiae. Trans. Timothy McDermott, O.P. London: Blackfriars, 1964. Print

Aquinas, Thomas. Summa Theologiae. Trans. Kevin D. O’Rourke, O.P. London: Blackfriars, 1964. Print.

Aquinas, Thomas. Summa Theologica. Trans. Fathers of the English Dominican Province. New York: Benziger Brothers, 1948. Print.

Bede. The Exposition on the Apocalypse in Ancient Christian Texts: Latin Commentaries on Revelation, Victorinus of Petovium, Apringius of Beja, Caesarius of Arles, and Bede the Venerable. Ed. and Trans. William C. Weinrich. Downers Grove, Illinois: IVP Academic, 2011. 110-162. Print.

Bernard of Clairvaux. Sermones in festivitate Omnium Sanctorum 1-5 in Sancti Bernardi opera.

Eds. Jean Leclercq, C. H. Talbot, and H. M. Rochais. Rome: Editiones Cistercienses, 1957-77. Print.

The Holy Bible, Douay Rheims Version. Revised by Bishop Richard Challoner. Rockford, Illinois: Tan Books and Publishers, 2000. Print.

Biblia Sacra Vulgata. Ed. Roger Gryson. Stuttgart: Deutsche Bibelgesellschaft, 1994. Print. 
Caesarius of Arles. Exposition on the Apocalypse in Ancient Christian Texts: Latin Commentaries on Revelation, Victorinus of Petovium, Apringius of Beja, Caesarius of Arles, and Bede the Venerable. Ed. and Trans. William C. Weinrich. Downers Grove, Illinois: IVP Academic, 2011. 63-106. Print.

The Cloud of Unknowing. Ed. Patrick J. Gallacher. Kalamazoo: Medieval Institute Publications, 2005. Print.

Chaucer, Geoffrey. The Riverside Chaucer. Ed. Larry D. Benson. Boston: Houghton Mifflin Company, 1987. Print.

Chrysostom, John. The Cult of the Saints. Ed. Wendy Mayer. Crestwood, NY: St Vladimir's Seminary Press, 2006. Print.

Jacobus a Voragine. Legenda aurea. Ed. T. Graesse. Osnabrück: Otto Zeller Verlag, 1969. Print. Jacobus de Voragine. The Golden Legend. Trans. William Granger Ryan. Princeton: Princeton University Press, 2012. Print.

John of the Cross. "The Dark Night" in The Collected Works of St. John of the Cross. Trans. Kieran Kavanaugh, O.C.D. and Otilio Rodriguez, O.C.D. Washington D.C.: ICS Publications, 1991. Print.

Mandeville, John. The Book of John Mandeville. Eds. Tamarah Kohanski and C. David Benson. Kalamazoo: Medieval Institute Publications, 2007. Print.

Mandeville, John. The Egerton Version of Mandeville's Travels. Ed. M. C. Seymour. Oxford: Oxford University Press, 2010. Print. 
Mandeville, John. The Travels of Sir John Mandeville. Ed. and Trans. C. W. R. D. Moseley. London: Penguin, 1983. Print.

Middle English Legends of Women Saints. Ed. Sherry L. Reames. Kalamazoo: Medieval Institute Publications, 2003. Print.

Nicolas of Lyra. Nicholas of Lyra's Apocalypse Commentary. Trans. Philip D. W. Krey. Kalamazoo: Medieval Institute Publications, 1997. Print.

Pearl in Sir Gawain and the Green Knight, Pearl, Cleanness, Patience. Ed. J. J. Anderson. London: Orion Publishing Group, 2005. Print.

Prudentius. Liber Peristephanon. Trans. H. J. Thomson. Cambridge: Harvard University Press, 1953. Print.

Pseudo-Dionysius. Pseudo-Dionysius: The Complete Works. Ed. John Farina. Trans. Colm Luibheid. New York: Paulist Press, 1988. Print.

The Sarum Missal. Ed. J. Wickham Legg. Oxford: Clarendon Press, 1969. Print.

Shakespeare, William. The Tempest. Ed. David Lindley. Cambridge: Cambridge University Press, 2013. Print.

The South English Legendary. Eds. Charlotte D'Evelyn and Anna J. Mill. Oxford: Oxford University Press, 1956. Print.

Victorinus of Pettau. Commentary on the Apocalypse in Ancient Christian Texts: Latin Commentaries on Revelation, Victorinus of Petovium, Apringius of Beja, Caesarius of Arles, and Bede the Venerable. Ed. and Trans. William C. Weinrich. Downers Grove, Illinois: IVP Academic, 2011. 1-20. Print. 
Secondary Sources

Adams, Robert Merrihew. The Virtue of Faith and Other Essays in Philosophical Theology. Oxford: Oxford University Press, 1987. Print.

Aers, David. “The Self Mourning: Reflections on Pearl.” Speculum 68 1993: 54-73. Print.

Alexander, Dominic. Saints and Animals in the Middle Ages. Suffolk: Boydell Press, 2008. Print.

Allen, Elizabeth. False Fables and Exemplary Truth: Poetics and Reception of Medieval Mode. London: Palgrave Macmillan, 2005. Print.

Ashley, Kathleen, and Pamela Sheingorn. Writing Faith: Text, Sign, and History in the Miracles of Sainte Foy. Chicago: University of Chicago Press, 1999. Print.

Balentine, Samuel E. The Hidden God: The Hiding of the Face of God in the Old Testament. Oxford: Oxford University Press, 1983. Print.

Balthasar, Hans Urs von. Mysterium Paschale. Trans. Aidan Nichols, O.P. London: T\&T Clark, 1990. Print.

Barr, Helen. "Pearl, or 'The Jeweller's Tale.”” Medium Aevum 69 2000: 59-79. Print.

Bartlett, Robert. Why Can the Dead Do Such Great Things? Saints and Worshippers from the Martyrs to the Reformation. Princeton: Princeton University Press, 2013. Print.

Bauman, Richard A. Crime and Punishment in Ancient Rome. New York: Routledge, 1996. Print.

Beacham, Richard C. Spectacle Entertainments of Early Imperial Rome. New Haven: Yale University Press, 1999. Print. 
Bejczy, István P., ed. Virtue Ethics in the Middle Ages: Commentaries on Aristotle's Nicomachean Ethics, 1200-1500. Leiden: Brill, 2008. Print.

Bell, Rudolph. Holy Anorexia. Chicago: University of Chicago Press, 1985. Print.

Benn, James. "Spontaneous Human Combustion: Some Remarks on a Phenomenon in Chinese Buddhism." Heroes and Saints: The Moment of Death in Cross-cultural Perspectives. Eds. Phyllis Granoff and Koichi Shinohara. Newcastle: Cambridge Scholars Publishing, 2007. 101-135. Print.

Bennett, Josephine Waters. The Rediscovery of Sir John Mandeville. New York: Kraus Reprint, 1971. Print.

Bildhauer, Bettina, and Robert Mills. Introduction. The Monstrous Middle Ages. Eds. Bettina Bildhauer and Robert Mills. Cardiff: University of Wales Press, 2003. 1-27. Print.

Blumenfeld-Kosinski, Renate. Not of Woman Born: Representations of Caesarean Birth in Medieval and Renaissance Culture. Ithaca: Cornell University Press, 1990. Print.

Blurton, Heather, and Jocelyn Wogan-Browne. "Rethinking the South English Legendaries." Rethinking the South English Legendaries. Eds. Heather Blurton and Jocelyn WoganBrowne. Manchester: Manchester University Press, 2011. Print.

Boesel, Chris, and Catherine Keller. Introduction. Apophatic Bodies: Negative Theology, Incarnation, and Relationality. Eds. Chris Boesel and Catherine Keller. New York: Fordham University Press, 2010. 1-24. Print.

Bogdanos, Theodore. Pearl: Image of the Ineffable: A Study in Medieval Poetic Symbolism. University Park: Pennsylvania State Press, 1983. Print. 
Borroff, Marie. Traditions and Renewals: Chaucer, the Gawain-Poet, and Beyond. New Haven: Yale University Press, 2003. Print.

Bowersock, G. W. Martyrdom and Rome. New York: Cambridge University Press, 1995. Print.

Brown, Peter. The Cult of the Saints: Its Rise and Function in Latin Christianity. Chicago: University of Chicago Press, 1982. Print.

Brown, Peter. "The Rise and Function of the Holy Man in Late Antiquity." The Journal of Roman Studies 61 1971: 80-101. Print.

Brown, Rachel Fulton. From Judgment to Passion: Devotion to Christ and the Virgin Mary, 8001200. New York: Columbia University Press, 2005. Print.

Burrus, Virginia. Saving Shame: Martyrs, Saints, and Other Abject Subjects. Philadelphia: University of Pennsylvania Press, 2008. Print.

Burrus, Virginia. The Sex Lives of Saints: An Erotics of Ancient Hagiography. Philadelphia: University of Pennsylvania Press, 2007. Print.

Bynum, Caroline Walker. Fragmentation and Redemption: Essays on Gender and the Human Body in Medieval Religion. New York: Zone Books, 1992. Print.

Bynum, Caroline Walker. Holy Feast and Holy Fast: The Religious Significance of Food to Medieval Women. Berkeley: University of California Press, 1987. Print.

Bynum, Caroline Walker. The Resurrection of the Body in Western Christianity, 200-1336. New York: Columbia University Press, 1995. Print.

Bynum, Caroline Walker. “Wonder.” American Historical Review 1997: 1-17. Print. 
Camille, Michael. The Gothic Idol: Ideology and Image-Making in Medieval Art. Cambridge: Cambridge University Press, 1991. Print.

Camille, Michael. Image on the Edge: The Margins of Medieval Art. London: Reaktion Books, 2008. Print.

Carabine, Deirdre. The Unknown God: Negative Theology in the Platonic Tradition: Plato to Eriugena. Louvain: Peeters Press, 1995. Print.

Castelli, Elizabeth A. Martyrdom and Memory: Early Christian Culture Making. New York: Columbia University Press, 2004. Print.

Cohen, Jeffrey Jerome. Of Giants: Sex, Monsters, and the Middle Ages. Minneapolis: University of Minnesota Press, 1999. Print.

Coward, Harold, and Toby Foshay, eds. Derrida and Negative Theology. Albany: State University of New York Press, 1992. Print.

Crossley-Holland, Kevin. The Norse Myths. New York: Pantheon Books, 1980. Print.

Cunningham, Lawrence S. "Saints and Martyrs: Some Contemporary Considerations.” Theological Studies 60 1999: 529-537. Print.

Deal, William E. Handbook to Life in Medieval \& Early Modern Japan. New York: Facts on File, 2006. Print.

De Blacam, Hugh. The Saints of Ireland: The Life-Stories of SS. Brigid and Columcille. Milwaukee: The Bruce Publishing Company, 1942. Print.

Drewer, Lois. "Margaret of Antioch the Demon-Slayer, East and West: The Iconography of the Predella of the Boston Mystic Marriage of St Catherine." Gesta 32 1993: 11-20. Print. 
Dupanloup, Félix. “The Manner of Writing a Saint's Life.” Introduction. St. Chantal and the Foundation of the Visitation. New York: Benziger Brothers, 1895. Print.

Earl, James W. "Saint Margaret and the Pearl Maiden.” Modern Philology 7 1972: 1-8. Print.

Ehrman, Bart D. The Lost Christianities: The Battles for Scripture and the Faiths We Never Knew. Oxford: Oxford University Press, 2003. Print.

Ellsberg, Robert. All Saints: Daily Reflections on Saints, Prophets, and Witnesses of Our Time. New York: The Crossroad Publishing Company, 1999. Print.

Elsner, Jaś. Art and the Roman Viewer: the Transformation of Art from the Pagan World to Christianity. Cambridge: Cambridge University Press, 1995. Print.

Elsner, Jaś, and Ian Rutherford. Introduction. Pilgrimage in Graeco-Roman \& Early Christian Antiquity. Eds. Jaś Elsner and Ian Rutherford. Oxford: Oxford University Press, 2005. 140. Print.

Elsner, Jaś. "Piety and Passion: Contest and Consensus in the Audiences for Early Christian Pilgrimage." Pilgrimage in Graeco-Roman \& Early Christian Antiquity: Seeing the Gods. Eds. Jaś Elsner and Ian Rutherford. Oxford: Oxford University Press, 2005. 411434. Print.

Eyerman, Ron. Cultural Trauma: Slavery and the Formation of African American Identity. Cambridge: Cambridge University Press, 2001. Print.

Field, Rosalind. "The Heavenly Jerusalem in Pearl.” The Modern Language Review 81 1986: 7 17. Print. 
Fleck, Andrew. 'Here, There, and In between: Representing Difference in the 'Travels' of Sir John Mandeville.” Studies in Philology 97 2000: 379-400. Print.

Frank, Georgia. "Miracles, Monks, and Monuments: The Historia Monachorum in Aegypto as Pilgrims’ Tales.” Pilgrimage and Holy Space in Late Antique Egypt. Ed. David Frankfurter. Leiden: Brill, 1998. 483-506. Print.

Frankis, John. "The Social Context of Vernacular Writing in Thirteenth-century England: the Evidence of the Manuscripts.” Rethinking the South English Legendaries. Eds. Heather Blurton and Jocelyn Wogan-Browne. Manchester: Manchester University Press, 2011. 66-83. Print.

Futrell, Alison. Blood in the Arena: The Spectacle of Roman Power. Austin: University of Texas Press, 1997. Print.

Geary, Patrick J. Furta Sacra: Thefts of Relics in the Central Middle Ages. Princeton: Princeton University Press, 1978. Print.

Gillespie, Vincent, and Maggie Ross. "The Apophatic Image: The Poetics of Effacement in Julian of Norwich." The Medieval Mystical Tradition in England. Ed. M. Glasscoe. Cambridge: D. S. Brewer, 1992. 53-77. Print.

Greenblatt, Stephen. Marvelous Possessions: The Wonder of the New World. Chicago: The University of Chicago Press, 1991. Print.

Gross, Kenneth. The Dream of the Moving Statue. University Park: Penn State Press, 2006. Print.

Hall, Dianne. Women and the Church in Medieval Ireland, c. 1140-1540. Dublin: Four Courts Press, 2003. Print. 
Harpham, Geoffrey Galt. The Ascetic Imperative in Culture and Criticism. Chicago: University of Chicago Press, 1987. Print.

Harrington, Christina. Women in a Celtic Church, Ireland 450-1150. Oxford: Oxford University Press, 2002. Print.

Harrison, Anna. “Community Among the Saintly Dead: Bernard of Clairvaux's Sermons for the Feast of All Saints." Last Things: Death \& The Apocalypse in the Middle Ages. Eds. Caroline Walker Bynum and Paul Freedman. Philadelphia: University of Pennsylvania Press, 2000. 191-204. Print.

Hart, Kevin. Poetry and Revelation. London: Bloomsbury, (forthcoming). Print.

Hauerwas, Stanley. Sanctify Them in Truth: Holiness Exemplified. Nashville: Abingdon Press, 1998. Print.

Hawkins, Peter S. "Dante's Paradiso and the Dialectic of Ineffability." Ineffability: Naming the Unnamable from Dante to Beckett. Eds. Peter S. Hawkins and Anne Howland Schotter. New York: AMS Press, 1984. 5-22. Print.

Head, Thomas. Introduction. Medieval Hagiography: An Anthology. Ed. Thomas Head. New York: Routledge, 2001. xiii-xxxviii. Print.

Henry, Michel. Seeing the Invisible, On Kandinsky. Trans. Scott Davidson. New York: Continuum, 2009. Print.

Higgins, Iain Macleod, ed. and trans. The Book of John Mandeville with Related Texts. Indianapolis: Hackett Publishing Company, 2011. Print. 
Higgins, Iain Macleod. Writing East: The "Travels" of Sir John Mandeville. Philadelphia: University of Pennsylvania Press, 1997. Print.

Hollywood, Amy. Sensible Ecstasy: Mysticism, Sexual Difference, and the Demands of History. Chicago: University of Chicago Press, 2002. Print.

Holsinger, Bruce. "Parchment Ethics: A Statement of More than Modest Concern." New Medieval Literatures 12 2010: 131-136. Print.

Holum, Kenneth G. "Hadrian and St. Helena: Imperial Travel and the Origins of Christian Holy Land Pilgrimage." The Blessings of Pilgrimage. Ed. Robert Ousterhout. Urbana: University of Illinois Press, 1990. Print.

Howard, Donald R. Writers and Pilgrims: Medieval Pilgrimage Narratives and Their Posterity. Berkeley: University of California Press, 1980. Print.

Irwin, Alexander. Saints of the Impossible: Bataille, Weil, and the Politics of the Sacred. Minneapolis: University of Minnesota Press, 2002. Print.

Ivanović, Filip. Symbol and Icon: Dionysius the Areopagite and the Iconoclastic Crisis. Eugene, OR: Pickwick Publications, 2010. Print.

Jackson, Ralph, ed. Gladiators and Caesars: The Power of Spectacle in Ancient Rome. London: British Museum Press, 2000. Print.

James, Paula. "Prudentius' Psychomachia: The Christian Arena and the Politics of Display." Constructing Identities in Late Antiquity. Ed. Richard Miles. London: Routledge, 1999. 70-94. Print.

Johnson, Elizabeth. "May We Invoke the Saints?” Theology Today 44 1987: 32-52. Print. 
Joly, Henri. The Psychology of the Saints. Fort Collins, CO: Roman Catholic Books. (First published 1898). Print.

Justice, Steven. "Did the Middle Ages Believe in Their Miracles?" Representations 103 2008: 129. Print.

Justice, Steven. "Eucharistic Miracle and Eucharistic Doubt." Journal of Medieval and Early Modern Studies 42 2012: 307-332. Print.

Karnes, Michelle. "Marvels and the Medieval Imagination.” Speculum 90 2015: 327-365. Print.

Kelly, Kathleen Coyne, and Marina Leslie, eds. Menacing Virgins: Representing Virginity in the Middle Ages and Renaissance. Newark: University of Delaware Press, 1999. Print.

Kelly, Henry Ansgar. Ideas and Forms of Tragedy, from Aristotle to the Middle Ages. Cambridge: Cambridge University Press, 1993. Print.

Kerby-Fulton, Kathryn. Books Under Suspicion: Censorship and Tolerance of Revelatory Writing in Late Medieval England. Notre Dame: University of Notre Dame Press, 2006. Print.

Kleinberg, Aviad M. “Apophthegmata.” Saints: Faith Without Borders. Eds. Françoise Meltzer and Jaś Elsner. Chicago: University of Chicago Press, 2011. 393-396. Print.

Kleinberg, Aviad M. Prophets in Their Own Country: Living Saints and the Making of Sainthood in the Later Middle Ages. Chicago: University of Chicago Press, 1992. Print.

Krueger, Derek. Writing and Holiness: The Practice of Authorship in the Early Christian East. Philadelphia: University of Pennsylvania Press, 2004. Print. 
Kyle, Donald G. Spectacles of Death in Ancient Rome. New York: Routledge, 1998. Print.

Lang, Helen S. Aristotle's Physics and its Medieval Varieties. Albany: State University of New York Press, 1992. Print.

Larson, Wendy R., ed. and trans. "Three Thirteenth-Century Lives of St. Margaret of Antioch." Medieval Hagiography: An Anthology. Ed. Thomas Head. New York: Routledge, 2001. 675-708. Print.

Leclercq, Jean, O.S.B. The Love of Learning and the Desire for God: A Study of Monastic Culture. New York: Fordham University Press, 1982. Print.

Lefebure, Molly. Samuel Taylor Coleridge: A Bondage of Opium. New York: Stein and Day, 1974. Print.

Le Goff, Jacques. In Search of Sacred Time: Jacobus de Voragine and The Golden Legend. Princeton: Princeton University Press, 2014. Print.

Logan, Alastair. The Gnostics: Identifying an Early Christian Cult. London: T\&T Clark, 2006. Print.

Louth, Andrew. “'Truly Visible Things Are Manifest Images of Invisible Things': Dionysios the Areopagite on Knowing the Invisible." Seeing the Invisible in Late Antiquity and the Early Middle Ages. Eds. Giselle de Nie, Karl F. Morrison, and Marco Mostert. Turnhout: Brepols, 2005. Print.

Lyotard, Jean-François. The Confession of Augustine. Trans. Richard Beardsworth. Stanford: Stanford University Press, 2000. Print. 
MacGregor, James B. "Negotiating Knightly Piety: The Cult of the Warrior-Saints in the West, ca. 1070-ca. 1200." Church History 73 2004: 317-345. Print.

Malamud, Martha A. A Poetics of Transformation: Prudentius and Classical Mythology. Ithaca: Cornell University Press, 1989. Print.

Marenbon, John. Pagans and Philosophers: The Problem of Paganism from Augustine to Leibniz. Princeton: Princeton University Press, 2015. Print.

Marion, Jean-Luc. Being Given: Toward a Phenomenology of Givenness. Trans. Jeffrey L. Kosky. Stanford: Stanford University Press, 2002. Print.

Marion, Jean-Luc. God Without Being. Trans. Thomas A. Carlson. Chicago: University of Chicago, 1991. Print.

Marion, Jean-Luc. The Essential Writings. Ed. Kevin Hart. New York: Fordham University Press, 2013. Print.

Marion, Jean-Luc. “The Invisibility of the Saint.” Saints: Faith Without Borders. Eds. Françoise Meltzer and Jaś Elsner. Trans. Christina M. Gschwandtner. Chicago: University of Chicago Press, 2011. 355-362. Print.

Marion, Jean-Luc. The Visible and the Revealed. Trans. Christina M. Gschwandtner. New York: Fordham University Press, 2008. Print.

McCarthy, David Matzko. Sharing God's Good Company: A Theology of the Communion of Saints. Grand Rapids: Eerdmans Publishing Co., 2012. Print. 
McCool, Gerald, A. “The Philosophical Theology of Rahner and Lonergan.” God Knowable and Unknowable. Ed. Robert J. Roth, S.J. New York: Fordham University Press, 1973. 123158. Print.

McInerney, Maud Burnett. Eloquent Virgins from Thecla to Joan of Arc. New York: Palgrave Macmillan, 2003. Print.

Meyer, Marvin, ed. The Gnostic Gospels of Jesus: The Definitive Collection of Mystical Gospels and Secret Books about Jesus of Nazareth. New York: Harper Collins, 2005. Print.

Miller, Patricia Cox. The Corporeal Imagination: Signifying the Holy in Late Ancient Christianity. Philadelphia: University of Pennsylvania Press, 2009. Print.

Miller, Patricia Cox. "Relics, Rhetoric and Mental Spectacles in Late Ancient Christianity." Seeing the Invisible in Late Antiquity and the Early Middle Ages. Eds. Giselle de Nie, Karl F. Morrison, and Marco Mostert. Turnhout: Brepols, 2005. 25-52. Print.

Miller, Patricia Cox. "Subtle Embodiments: Imagining the Holy in Late Antiquity." Apophatic Bodies: Negative Theology, Incarnation, and Relationality. Eds. Chris Boesel and Catherine Keller. New York: Fordham University Press, 2009. Print.

Mills, Robert. “Jesus as Monster.” The Monstrous Middle Ages. Eds. Bettina Bildhauer and Robert Mills. Cardiff: University of Wales Press, 2003. 28-54. Print.

Mitchell, J. Allan. Becoming Human: The Matter of the Medieval Child. Minneapolis: University of Minnesota Press, 2014. Print.

Mitchell, J. Allan. “The Middle English Pearl: Figuring the Unfigurable.” The Chaucer Review 35 2000: 86-109. Print. 
Morris, Colin. "Pilgrimage to Jerusalem in the late Middle Ages.” Pilgrimage: The English Experience from Becket to Bunyan. Eds. Colin Morris and Peter Roberts. Cambridge: Cambridge University Press, 2002. 141-163. Print.

Moseley, C. W. R. D. “The Metamorphoses of Sir John Mandeville.” The Yearbook of English Studies 4 1974: 5-25. Print.

Moseley, C. W. R. D. “'New Things to Speak of’: Money, Memory, and Mandeville's Travels in Early Modern England.” The Yearbook of English Studies 41 2011: 5-20. Print.

Moser, Paul K. “Cognitive Idolatry and Divine Hiding.” Divine Hiddenness: New Essays. Eds. Daniel Howard-Snyder and Paul K. Moser. Cambridge: Cambridge University Press, 2002. 120-148. Print.

Moss, Candida. Ancient Christian Martyrdom: Diverse Practices, Theologies, and Traditions. New Haven: Yale University Press, 2012. Print.

Moss, Candida. The Myth of Persecution: How Early Christians Invented a Story of Martyrdom. New York: HarperCollins, 2013. Print.

Moss, Candida. The Other Christs: Imitating Jesus in Ancient Christian Ideologies of Martyrdom. Oxford: Oxford University Press, 2012. Print.

Newman, Barbara. "The Artifice of Eternity: Speaking of Heaven in Three Medieval Poems.” Religion \& Literature 37 2005: 1-24. Print.

Newman, Barbara. God and the Goddesses: Vision, Poetry, and Belief in the Middle Ages. Philadelphia: University of Pennsylvania Press, 2003. Print. 
Newton, Lloyd A., ed. Medieval Commentaries on Aristotle's Categories. Leiden: Brill, 2008. Print.

Otto, Rudolf. The Idea of the Holy. Trans. John W. Harvey. Oxford: Oxford University Press, 1958. Print.

Parker, John. The Aesthetics of Antichrist: From Christian Drama to Christopher Marlowe. Ithaca: Cornell University Press, 2007. Print.

Putter, Ad. An Introduction to the Gawain-Poet. London: Longman, 1996. Print.

Rahner, Karl. Theological Investigations. Trans. David Bourke. Vol. 8. New York: The Seabury Press, 1977. Print.

Rambuss, Richard. Closet Devotions. Durham: Duke University Books, 1998. Print.

Rambuss, Richard. "Pleasure and Devotion: The Body of Jesus and Seventeenth-Century Religious Lyric." Queering the Renaissance. Ed. Jonathan Goldberg. Durham: Duke University Press, 1994. 253-279. Print.

Rankin, Andrew. Seppuku: A History of Samurai Suicide. New York: Kodansha USA, 2011. Print.

Rees, Elizabeth. Celtic Saints in Their Landscape. Stroud, Gloucestershire: Sutton Publishing, 2001. Print.

Rees, Elizabeth. Celtic Saints: Passionate Wanderers. London: Thames \& Hudson, 2000. Print.

Roberts, Michael. Poetry and the Cult of the Martyrs: The Liber Peristephanon of Prudentius. Ann Arbor: University of Michigan Press, 1993. Print. 
Rosenfeld, Jessica. Ethics and Enjoyment in Late Medieval Poetry: Love After Aristotle. Cambridge: Cambridge University Press, 2011. Print.

Salih, Sarah. "Idols and Simulacra: Paganity, Hybridity and Representation in Mandeville's Travels." The Monstrous Middle Ages. Eds. Bettina Bildhauer and Robert Mills. Cardiff: University of Wales Press, 2003. 113-133. Print.

Salih, Sarah. Versions of Virginity in Late Medieval England. Woodbridge, Suffolk: D. S. Brewer, 2001. Print.

Sanders, E. P. The Historical Figure of Jesus. London: Penguin, 1995. Print.

Sanok, Catherine. Her Life Historical: Exemplarity and Female Saints' Lives in Late Medieval England. Philadelphia: University of Pennsylvania Press, 2007. Print.

Scarry, Elaine. The Body in Pain: The Making and Unmaking of the World. Oxford: Oxford University Press, 1987. Print.

Schellenberg, J. L. Divine Hiddenness and Human Reason. Ithaca: Cornell University Press, 2006. Print.

Schotter, Anne Howland. "Vernacular Style and the Word of God: The Incarnation Art of Pearl." Ineffability: Naming the Unnamable from Dante to Beckett. Eds. Peter S. Hawkins and Anne Howland Schotter. New York: AMS Press, 1984. 23-34. Print.

Scullion, Scott. "“Pilgrimage and Greek Religion: Sacred and Secular in the Pagan Polis." Pilgrimage in Graeco-Roman \& Early Christian Antiquity. Eds. Jaś Elsner and Ian Rutherford. Oxford: Oxford University Press, 2005. 111-130. Print. 
Shah, Bruno M., O.P., and Beth Sutherland. "Theoretical Lunacy: a Commentary on Fitt XVIII of Pearl." Glossator 9 2015: 355-379. Print.

Sherry, Patrick. Spirits, Saints, and Immortality. Albany: State University of New York Press, 1984. Print.

Smith, Karen. "Snake-Maiden Transformation Narratives in Hagiography and Folklore.” Fabula 43 2002: 251-263. Print.

Smith, Morton. Jesus the Magician. New York: Barnes and Noble Books, 1978. Print.

Spearing, A. C. The Gawain-Poet: A Critical Study. Cambridge: Cambridge University Press, 1976. Print.

Spearing, A. C. Medieval Dream-Poetry. Cambridge: Cambridge University Press, 1976. Print.

Spyra, Piotr. The Epistemological Perspective of the Pearl-Poet. Surrey: Ashgate, 2014. Print.

Stouck, Mary-Ann, ed., Medieval Saints: A Reader. Peterborough, Ontario: Broadview Press, 1999. Print.

Telepneff, Gregory. The Egyptian Desert in the Irish Bogs: The Byzantine Character of Early Celtic Monasticism. Etna, CA: Center for Traditionalist Orthodox Studies, 2002. Print.

Thompson, Anne B. Everyday Saints and the Art of Narrative in the South English Legendary. Burlington, Vermont: Ashgate, 2003. Print.

Tracy, Larissa. Torture and Brutality in Medieval Literature: Negotiations of National Identity. Cambridge: D.S. Brewer, 2012. Print. 
Turner, Denys. "Apophaticism, Idolatry and the Claims of Reason." Silence and the Word: Negative Theology and Incarnation. Eds. Denys Turner and Oliver Davies. Cambridge: Cambridge University Press, 2008. 11-34. Print.

Turner, Petra. “The Unknown Saint: Reflections on Jean-Luc Marion's Understanding of Holiness." The Postmodern Saints of France: Refiguring 'the Holy' in Contemporary French Philosophy. Ed. Colby Dickinson. London: T\&T Clark, 2013. 231-248. Print.

Turner, Victor, and Edith Turner. Image and Pilgrimage in Christian Culture. New York: Columbia Press, 1978. Print.

Vauchez, André. Sainthood in the Later Middle Ages. Trans. Jean Birrell. Cambridge: Cambridge University Press, 1997. Print.

Vickers, Nancy J. "Diana Described: Scattered Woman and Scattered Rhyme.” Critical Inquiry 8 1981: 265-279. Print.

Ware, Timothy. The Orthodox Church. London: Penguin, 1993. Print.

Watson, Nicholas. "Censorship and Cultural Change in Late-Medieval England: Vernacular Theology, the Oxford Translation Debate, and Arundel's Constitutions of 1409." Speculum 70 1995: 822-864. Print.

Watson, Nicholas. "Cultural Changes.” English Language Notes 44 2006: 127-135. Print.

Watson, Nicholas. "Visions of Inclusion: Universal Salvation and Vernacular Theology in PreReformation England.” Journal of Medieval and Early Modern Studies 27 1997: 145187. Print. 
Watts, Ann Chalmers. "Pearl, Inexpressibility, and Poems of Human Loss.” PMLA 99 1984: 2640. Print.

Weingarten, Susan. The Saint's Saints: Hagiography and Geography in Jerome. Leiden: Brill, 2005. Print.

White, David Gordon. Myths of the Dog-Man. Chicago: University of Chicago Press, 1991. Print.

White, Monica. "The Rise of the Dragon in Middle Byzantine Hagiography." Byzantine and Modern Greek Studies 32 2008: 149-167. Print.

Wiedemann, Thomas E. Emperors and Gladiators. London: Routledge, 1992. Print.

Wilkinson, John. "Jewish Holy Places and the Origins of Christian Pilgrimage." The Blessings of Pilgrimage. Ed. Robert Ousterhout. Urbana: University of Illinois Press, 1990. Print.

Williams, Michael Allen. Rethinking Gnosticism: An Argument for Dismantling a Dubious Category. Princeton: Princeton University Press, 1996. Print.

Winstead, Karen. Virgin Martyrs: Legends of Sainthood in Late Medieval England. Ithaca: Cornell University Press, 1997. Print.

Wistrand, Magnus. Entertainment and Violence in Ancient Rome: The Attitudes of Roman Writers of the First Century A.D. Göteborg: Acta Universitatis Gothoburgensis, 1992. Print.

Woodward, Kenneth L. Making Saints: How the Catholic Church Determines Who Becomes a Saint, Who Doesn't, and Why. New York: Simon \& Schuster, 1990. Print.

Wolf, Susan. "Moral Saints.” The Journal of Philosophy 79 1982: 419-439. Print. 
Wyschogrod, Edith. Saints and Postmodernism: Revisioning Moral Philosophy. Chicago: University of Chicago Press, 1990. Print.

Zamora, Lois Parkinson, and Wendy B. Faris. "Introduction: Daiquiri Birds and Flaubertian Parrot(ie)s." Magical Realism: Theory, History, Community. Durham: Duke University Press, 1995. 1-14. Print. 